U.S. Department of the Interior

U.S. Geological Survey

\title{
Water-Resources Investigations in Wisconsin, 2001
}

Open-File Report 01-254

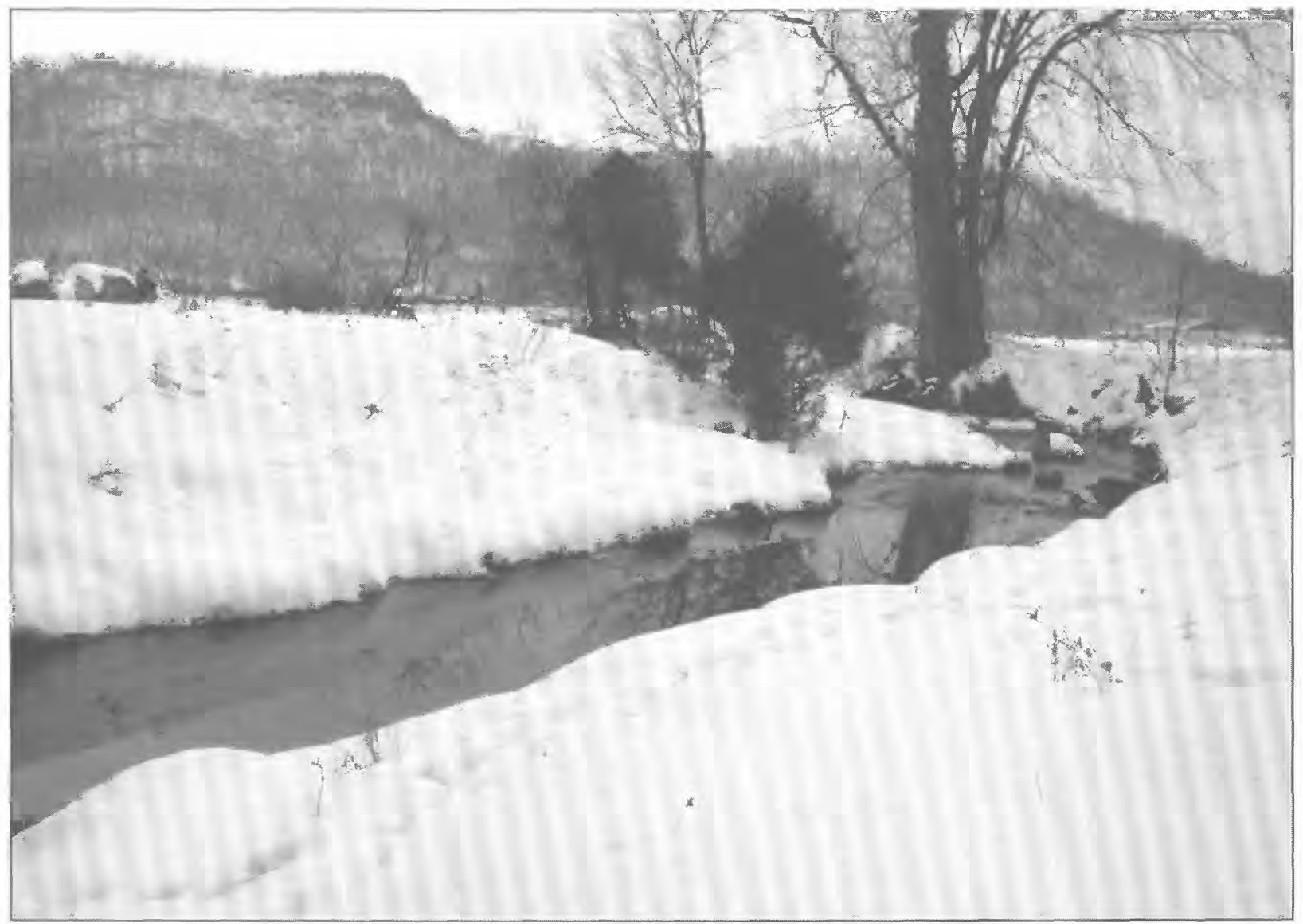

Poplar Coulee Creek, Vernon County

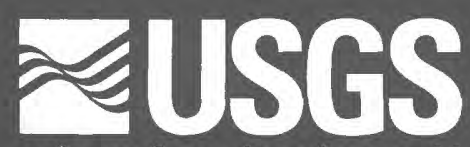




\section{WATER-RESOURCES INVESTIGATIONS IN WISCONSIN, 2001}

Compiled by D.E. Maertz and J.A. Fuller

U.S. GEOLOGICAL SURVEY

Open-File Report 01-254

Middleton, Wisconsin

2001 


\section{U.S. DEPARTMENT OF THE INTERIOR}

Gale A. Norton, Secretary

U.S. GEOLOGICAL SURVEY

Charles G. Groat, Director

For additional information write to:

District Chief

U.S. Geological Suvey

8505 Research Way

Middleton, WI 53562
Copies of this report can be purchased from:

U.S. Geological Survey

Branch of Information Services

P.O. Box 25286

Denver, CO 80225-0286

Wisconsin District WRD home page: http://wi.water.usgs.gov/

Wisconsin Real-Time Water Data: http://wi.water.usgs.gov/rt-cgi/gen_tbl_pg

Wisconsin Ground Water page: http://wi.water.usgs.gov/gw/

USGS home page: http://www.usgs.gov/ 


\section{CONTENTS}

Program

Basic data collection

00100

00200

00201

00302

00303

00304

00351

00400

00700

Interpretive studies

10900

12301

12303

12306

12312

13300

14500

16400

17202,04

17213

17206

17207

17208

17209

17214

17223

17229

17230

17231

17232

17233

17234

17235

17236

17237

17238

17301

17302

17303

17304

17305

17306

Collection of basic records-surface water ....................................................................

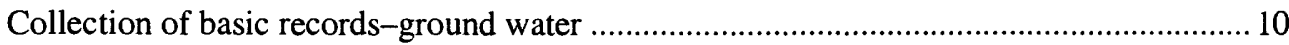

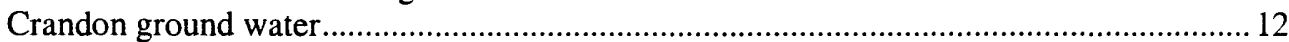

Collection of basic records-Dane County Program............................................................... 13

Interagency methods and data comparability board (MDCB) .......................................... 14

Age dating ground water in atrazine prohibition areas in Wisconsin ................................... 15

Ground-water age dating in the Little Plover River Basin............................................... 16

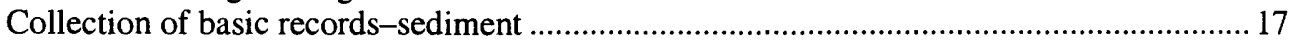

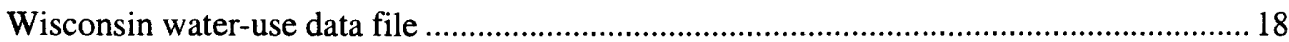

Regional flood-frequency study for urban and rural streams in Wisconsin ........................ 19

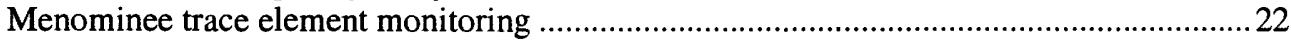

Compilation and analysis of water-resources data near the St. Croix Reservation ...............24

Oneida Nation hydrologic investigations............................................................................25

Delineation of the area of ground-water contribution and the times of travel to community water systems on the Menominee Indian Reservation ...............................26

Lake water-quality monitoring, chemical and biological monitoring of

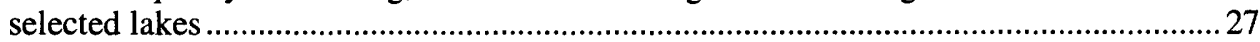

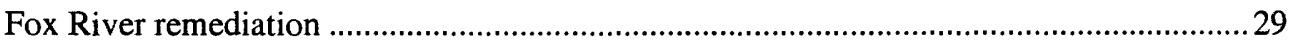

Technical and field support for U.S. Environmental Protection Agency,

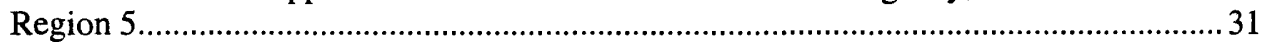

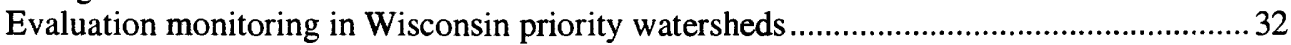

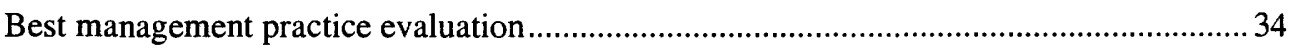

Verification of treatment performance of the Vortechnics and stormwater

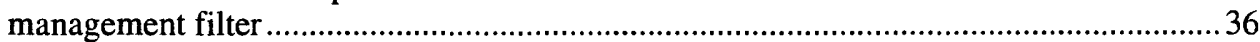

Verification of a pressurized stormwater filtration system at St. Mary's Hospital................. 37

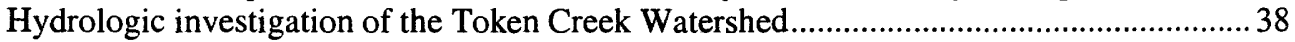

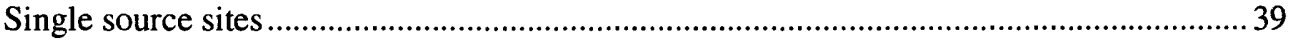

Impact of phosphorus and nitrogen concentrations on the biological integrity of Wisconsin streams ............................................................................................ 41

Hydrology and water-quality impacts of different pasture management

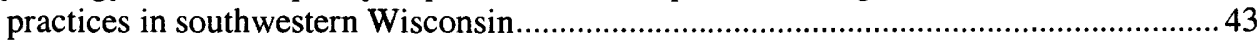

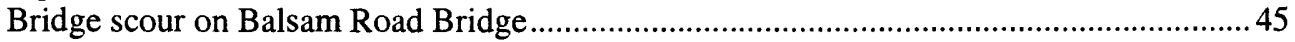

Evaluating improved street sweeping for enhancing water quality in highway runoff in Milwaukee ............................................................................................4 46

Quantification of solids loading from residential and commercial construction sites in Dane County, Wisconsin ...............................................................4 4

Evaluation of the effectiveness of low impact development practices ..................................4 48

Temperature modeling of urban stormwater runoff................................................................5 50

Impacts of residential construction on stream water quality ..............................................51.

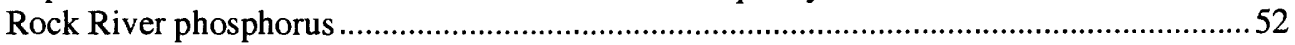

Evaluation of street sweeping as a water-quality management tool

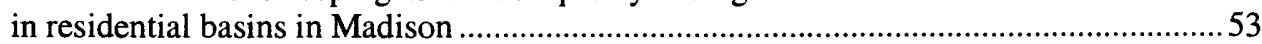

Monitoring contaminant flux from a stormwater infiltration facility to

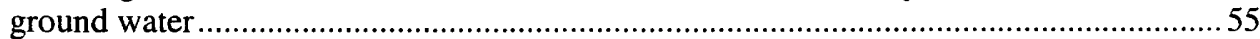

Assessment of the hydrology and water quality of, and phosphorus loading

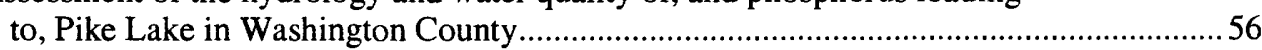

Miscellaneous monitoring associated with lakes ...........................................................5 57

Wisconsin Lakes, Green Lake tributary monitoring ......................................................5

Pool 8 ground-water/surface-water study …….................................................................5

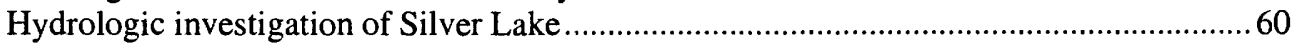

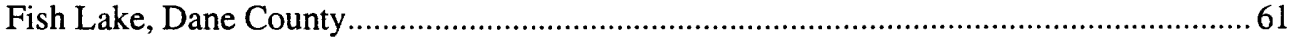


Water quality of the Red Cedar Lakes in response to hydrologic and phosphorus loading.

Assessment of phosphorus loading, winter anoxia, and stage regulation

of Little St. Germain Lake, Vilas County

Assessment of the water quality, hydrology, and biology of Geneva Lake.

Determination of streamflow, phosphorus, and solids loads at three sites above Sinissippi Lake in Dodge County

Western Lake Michigan Drainages National Water-Quality Assessment (NAWQA)

Upper Illinois River Basin National Water-Quality Assessment (NAWQA)

Technical assistance in the development of regional nutrient criteria for the Nation.

Hydrologic and biogeochemical budgets in temperate lakes and

their watersheds, Northern Wisconsin.

18101

18900

19101

19300

19700

20200,03

20204

20201

20400

Assessment of the hydrology, water quality, and biology of Delavan Lake

Dane County Regional hydrologic study

Transport of PCBs at two sites on Cedar Creek................................................................. 79

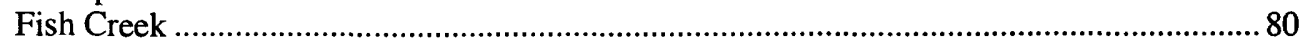

Florida Everglades mercury cycling ............................................................................... 82

Mitigation of future North Fork urbanization impacts on the Pheasant Branch hydrologic system.

Mitigation of future impacts of urbanization on the Badger Mill Creek hydrologic system.

Monitoring and evaluation of the impacts of aircraft and runway deicers on the

Kinnickinnic River surface-water resources

Modeling the effects of the Crandon Mine using the HSPF watershed model

Developing a geographic information system (GIS) database development and support of modflow and HSPF modeling efforts related to the proposed Crandon Mine

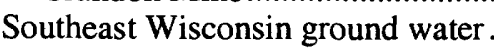

Database applications.

Wisconsin Department of Natural Resources biology database ...........................................96

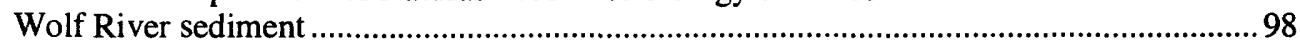

21202 ,

St. Croix National Scenic Riverway-nutrient and sediment loading and long-term water-quality monitoring

St. Croix National Scenic Riverway - nutrient and sediment loading and sediment loading, water-quality monitoring and assessment partnership ....................................... 101

Historical ecosystem reconstruction and potential identification of effects of past ecosystem perturbations in Lac Courte Oreilles. 


\section{ILLUSTRATIONS}

Page

Figure 1. Organization chart of the U.S. Geological Survey, Water Resources Division, Wisconsin District. viii

2. Location of offices in the Wisconsin District ......................................................... ix

3. Funding sources for the water-resources program in Wisconsin for the 2001 fiscal year ................................................................................................. xi

4. 2000 runoff as percent of long-term average runoff .................................................. xii

5. Comparison of annual discharge at representative gaging stations to their long-term average discharge for water years 1916-2000 .................................... xiii

6. Comparison of discharge at representative gaging stations during water year 2000 with discharge for 1916-2000 ........................................................... xiv

7. Location of continuous-record data-collection stations ..................................................

8. Location of network observation wells .....................................................................

9. Location of crest-stage-gage data-collection stations ...................................................21 


\section{BASIC MISSION AND PROGRAMS}

\section{U.S. Geological Survey}

The U.S. Geological Survey was established by an act of Congress on March 3, 1879, to provide a permanent Federal agency to conduct the systematic and scientific "classification of the public lands, and examination of the geological structure, mineral resources, and products of national domain." An integral part of that original mission includes publishing and disseminating the earthscience information needed to understand, to plan the use of, and to manage the Nation's energy, land, mineral, and water resources.

Since 1879, the research and fact-finding role of the U.S. Geological Survey (USGS) has grown and has been modified to meet the changing needs of the Nation it serves. As part of the evolution, the USGS has become the Federal Government's largest earth-science research agency, the Nation's largest civilian map-making agency, the primary source of data on the Nation's surfacewater and ground-water resources, and the employer of the largest number of professional earth scientists in the Nation. Today's programs serve a diversity of needs and users. Programs include:

Conducting detailed assessments of the energy and mineral potential of land and offshore areas.

Investigating and issuing warnings of earthquakes, volcanic eruptions, landslides, and other geologic and hydrologic hazards.

Conducting research on the geologic structure of land and offshore areas.

Studying the geologic features, structure, processes, and history of the other planets of our solar system.

Conducting topographic surveys and preparing topographic and thematic maps and related cartographic products.

Developing and producing digital cartographic data bases and products.

Collecting data on a routine basis to determine the quantity, quality, and use of surface water and ground water.

Conducting water-resource appraisals to describe the consequences of alternative plans for developing land and water resources.

Conducting research in hydraulics and hydrology, and coordinating all Federal water-data acquisition.

Using remotely sensed data to develop new cartographic, geologic, and hydrologic research techniques for natural resources planning and management.

Providing earth-science information through an extensive publications program and a network of public access points.

Along with its continuing commitment to meet the growing and changing earth-science needs of the Nation, the USGS remains dedicated to its original mission to collect, analyze, interpret, publish, and disseminate information about the natural resources of the Nation-providing "Earth science in the public service." 


\section{Water Resources Division}

The mission of the Water Resources Division (WRD) is to provide the hydrologic information and understanding needed for the optimum utilization and management of the Nation's water resources for the overall benefit of the people of the United States. This mission is accomplished, in large part, through cooperation with other Federal and non-Federal agencies, by:

Collecting, on a systematic basis, data needed for the continuing determination and evaluation of the quantity, quality, and use of the Nation's water resources.

Conducting analytical and interpretive water-resource appraisals describing the occurrence, availability, and physical, chemical, and biological characteristics of surface water and ground water.

Conducting supportive basic and problem-oriented research in hydraulics, hydrology, and related fields of science to improve the scientific basis for investigations and measurement techniques and to understand hydrologic systems sufficiently well to quantitatively predict their response to stress.

Disseminating the water data and the results of these investigations and research through reports, maps, computerized information services, and other forms of public releases.

Coordinating the activities of Federal agencies in the acquisition of water data for streams, lakes, reservoirs, estuaries, and ground water.

Providing scientific and technical assistance in hydrologic fields to other federal, state, and local agencies, to licensees of the Federal Energy Regulatory Commission, and to international agencies on behalf of the U.S. Department of State. 


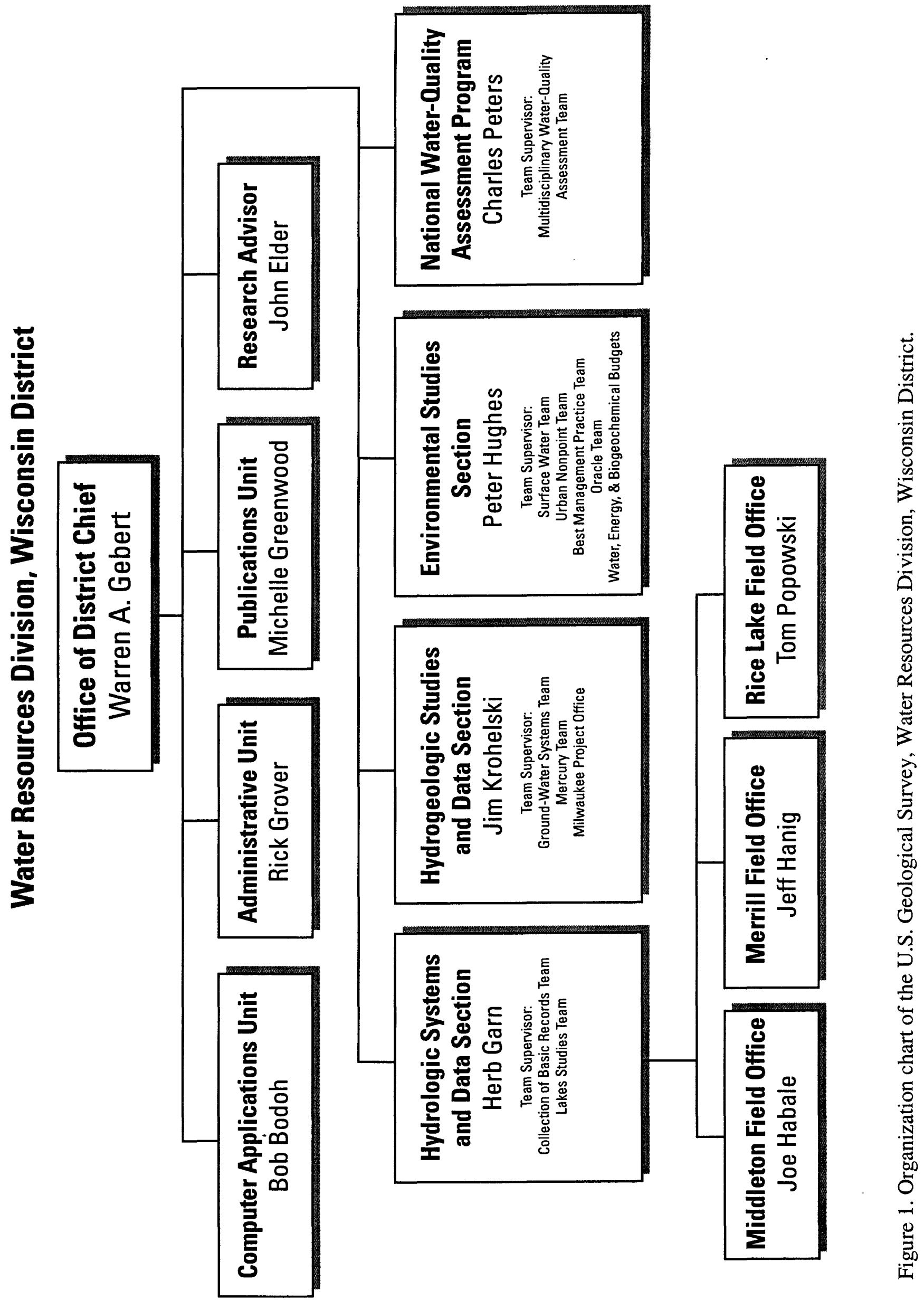




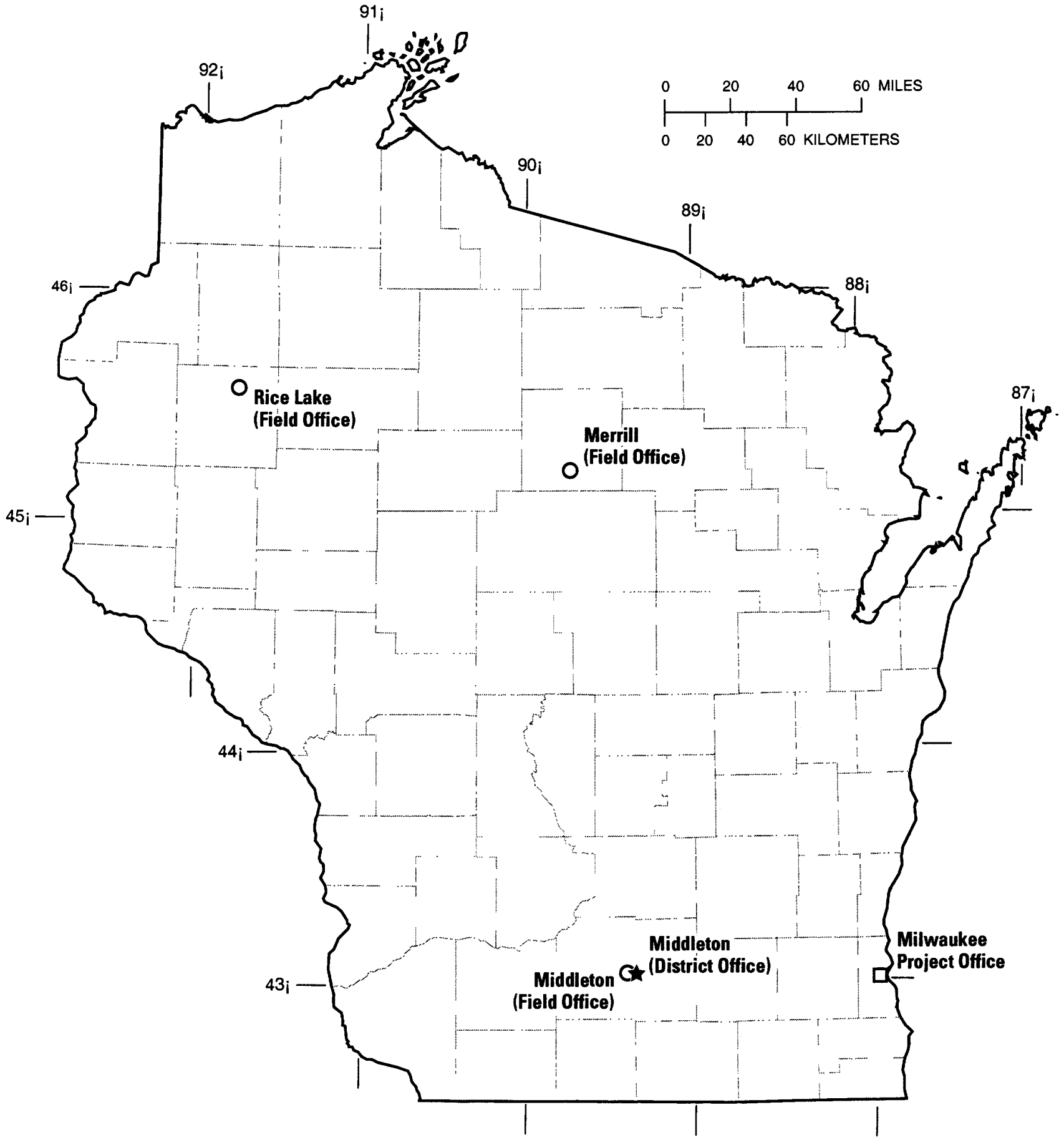

Figure 2. Location of offices in the Wisconsin District. 


\section{COOPERATORS}

\section{State Agencies}

Illinois Department of Transportation

Kickapoo Reserve

University of Wisconsin, Stevens Point

Wisconsin Department of Agriculture, Trade, and Consumer Protection

Wisconsin Department of Natural Resources

Wisconsin Department of Transportation

Wisconsin Geological and Natural History Survey

Wisconsin State Laboratory of Hygiene

\section{Local Agencies}

City of Barron

City of Beaver Dam

City of Fond du Lac

City of Fort Atkinson

City of Hillsboro

City of Madison

City of Middleton

City of Milwaukee

City of Peshtigo

City of Sparta

City of Thorp

City of Waupun

County of Bayfield

County of Milwaukee

Dane County Lakes and Watershed Management

Dane County Land Conservation Department

Dane County Regional Planning Commission

Dane County Department of Planning \& Development

Fontana/Walworth Water Pollution Control Commission

Geneva Lake Environmental Agency

Green Bay Metropolitan Sewerage District

Joint Water Quality Commission of Danbury and

St. Croix Chippewa Indians of Wisconsin

Madison Metropolitan Sewerage District

Marathon County Highway Department

Milwaukee Metropolitan Sewerage District

Rock County Public Works Department

Rock River Watershed POTW

Southeastern Wisconsin Regional Planning Commission

St. Croix County Land Conservation Department

Village of Wittenberg

Walworth County Metropolitan Sewerage District

\section{Other Federal Agencies}

U.S. Army Corps of Engineers,

Detroit District

Rock Island District

St. Paul District

Vicksburg, MS
Other Federal Agencies (continued)

Federal Energy Regulatory Commission licensees

Black River Falls Municipal Utilities

Consolidated Paper Corporation, Niagara Division

Dairyland Power Cooperative

Northern States Power Company

Northwoods Hydropower

Wisconsin Electric Power Company

Wisconsin Public Service Corporation

Wisconsin Valley Improvement Company

National Park Service

U.S. Environmental Protection Agency

U.S. Fish and Wildlife

Indian Tribes

Bad River Band of Lake Superior Chippewa

Lac Courte Oreilles Tribe

Lac du Flambeau Band of Lake Superior Chippewa

Menominee Indian Tribe of Wisconsin

Oneida Tribe of Indians of Wisconsin

St. Croix Tribe of Wisconsin

Stockbridge-Munsee Band of Mohican Indians

\section{Lake Districts}

Big Cedar Lake District

Booth Lake Management District

Buffalo Lake District

City of Muskego

Eagle Spring Lake Management District

Green Lake Sanitary District

Lac La Belle Management District

Lauderdale Lakes Lake Management District

Little Cedar Lake Protection and Rehabilitation District

Little Green Lake Protection and Rehabilitation District

Little Muskego Lake Management District

Little St. Germain Protection and Rehabilitation District

Middle Genesee Lake District

Okauchee Lake District

Pike Lake Management District

Potter Lake Rehabilitation and Protection District

Powers Lake District

Silver Lake Protection and Rehabilitation District

Whitewater Rice Lake Management District

Wind Lake Management District

Town of Delavan

Town of Hubbard

Town of Sand Lake

Town of Wascott

Village of Oconomowoc Lake 


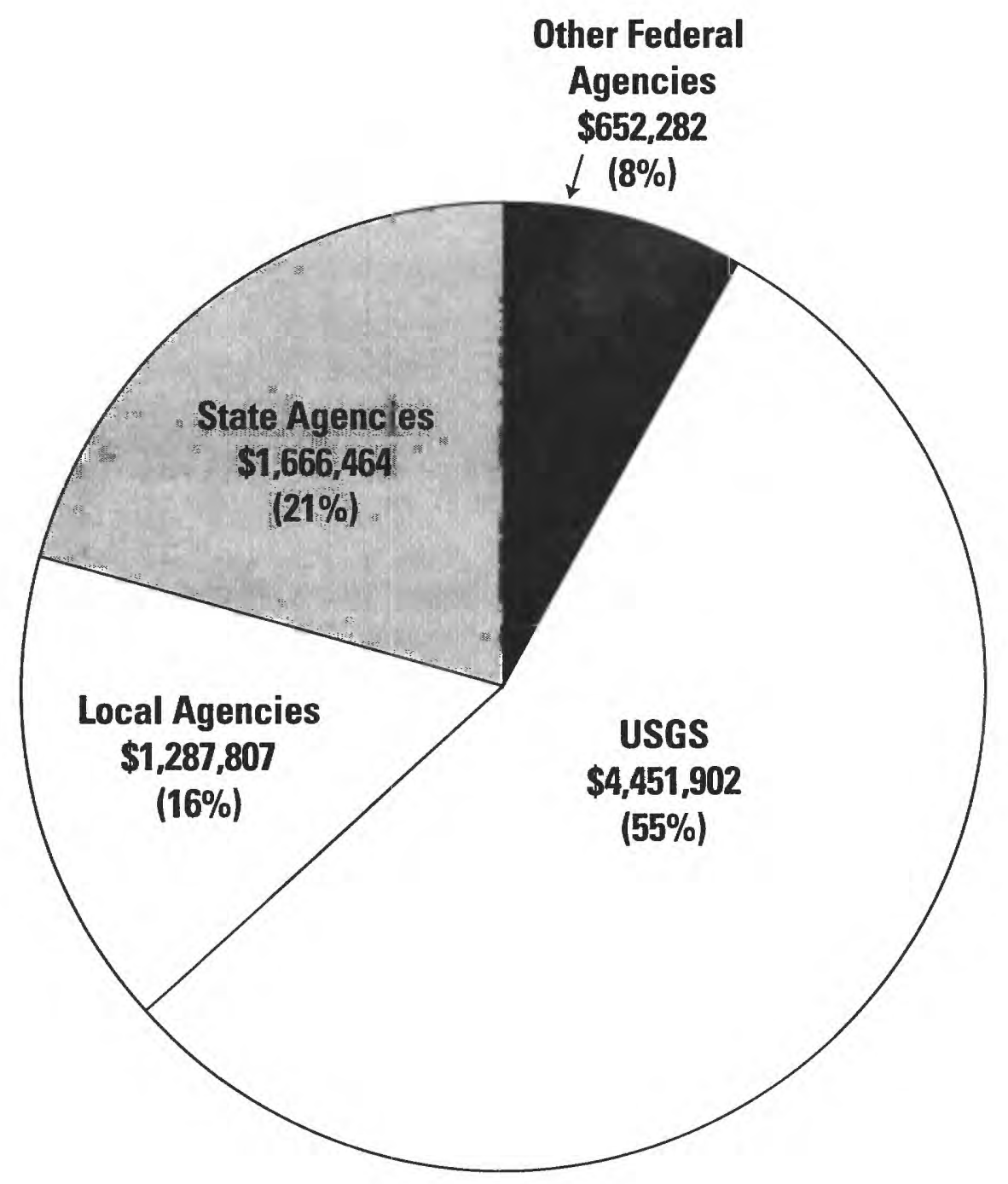

\section{Total Funding $=\$ \mathbf{8}, 058,455$}

Figure 3. Funding sources for the water-resources program in Wisconsin for the 2001 fiscal year. 


\section{SUMMARY OF HYDROLOGIC CONDITIONS}

\section{Streamflow}

The statewide average precipitation of 32.82 inches for the 2000 water year was 1.14 inches greater than the normal annual precipitation of 31.68 inches for water years 1961-90. Average precipitation values affecting streamflow conditions ranged from 90 percent of normal in northwest Wisconsin to 121 percent of normal in southeast Wisconsin (summary tables provided by Lyle Anderson, State Climatology Office, University of Wisconsin, Madison, written commun., 2001). Although precipitation for the year averaged only 104 percent of normal, the 2000 water year had extremes of beginning dry, turning very wet in the spring, and ending dry again. The year began below normal the first quarter of the year in all climatic divisions of the State. Record high temperatures in February and March and below normal snowfall brought an early spring and dry conditions statewide during March and April (Wisconsin Agricultural Statistics Service, 2000). The northern part of the State was still below normal for May. May and June brought record wet weather and cool temperatures for the southern half of the State: southeast Wisconsin received over 270 percent of normal rainfall for May, and southwest Wisconsin received over 250 percent of normal rainfall for June. June was the wettest month statewide, averaging 173 percent of normal. The last quarter of the year was more variable with the northern half of the State being below normal and the remainder near normal; heavy rains exceeding 10 inches for the month occurred in localized areas during July and September.

Runoff differed for rivers throughout the State and ranged from 33 percent in east central Wisconsin to 166 percent in south central Wisconsin. Runoff was lowest (33 percent of the average annual runoff from 19642000) for the Lake Michigan tributary Kewaunee River near Kewaunee, and highest (166 percent of the average annual runoff from 1974-2000) for the Pheasant Branch at Middleton station in south central Wisconsin. Departures of runoff in the 2000 water year as a percent of long-term average runoff in the State (determined using stations with drainage areas greater than 150 square miles and at least 20 years of record) are shown in Figure 4.
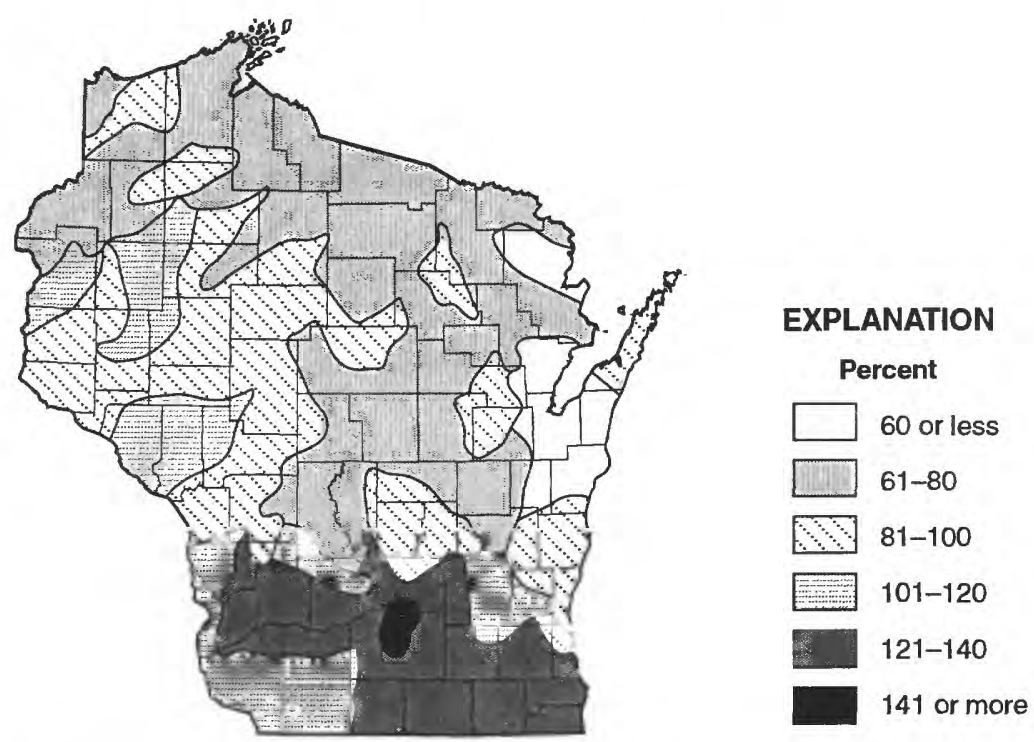

Figure 4. 2000 runoff as percentage of long-term average runoff.

Annual discharges for the individual water years (1916-2000) at the Oconto River near Gillett, Jump River at Sheldon, and Sugar River near Brodhead are shown in Figure 5. The comparison of monthly and annual discharges for the 2000 water year to discharge for a 85 -year base period at the same three gaging stations are shown in Figure 6. 
05436500 SUGAR RIVER NEAR BRODHEAD

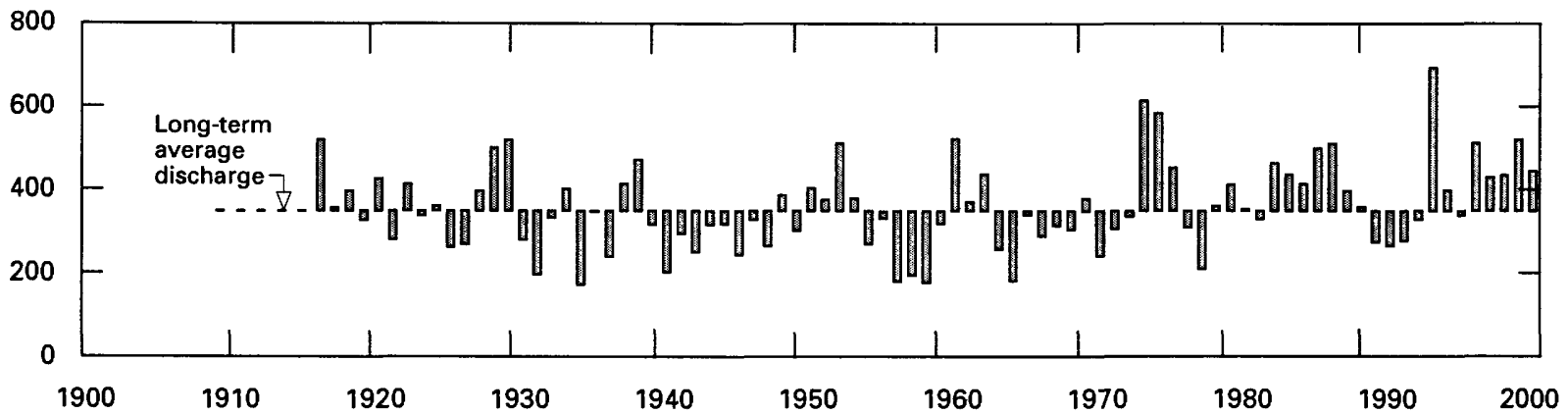

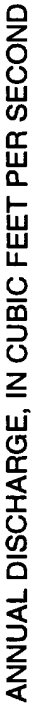

05362000 JUMP RIVER AT SHELDON

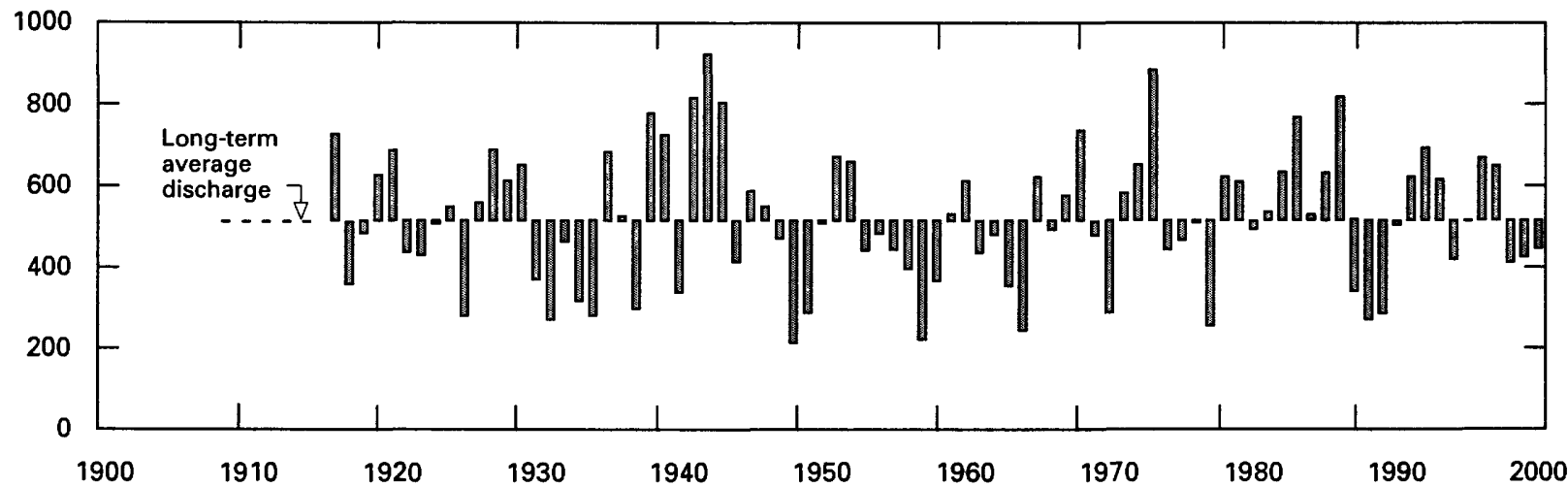

04071000 OCONTO RIVER NEAR GILLETT

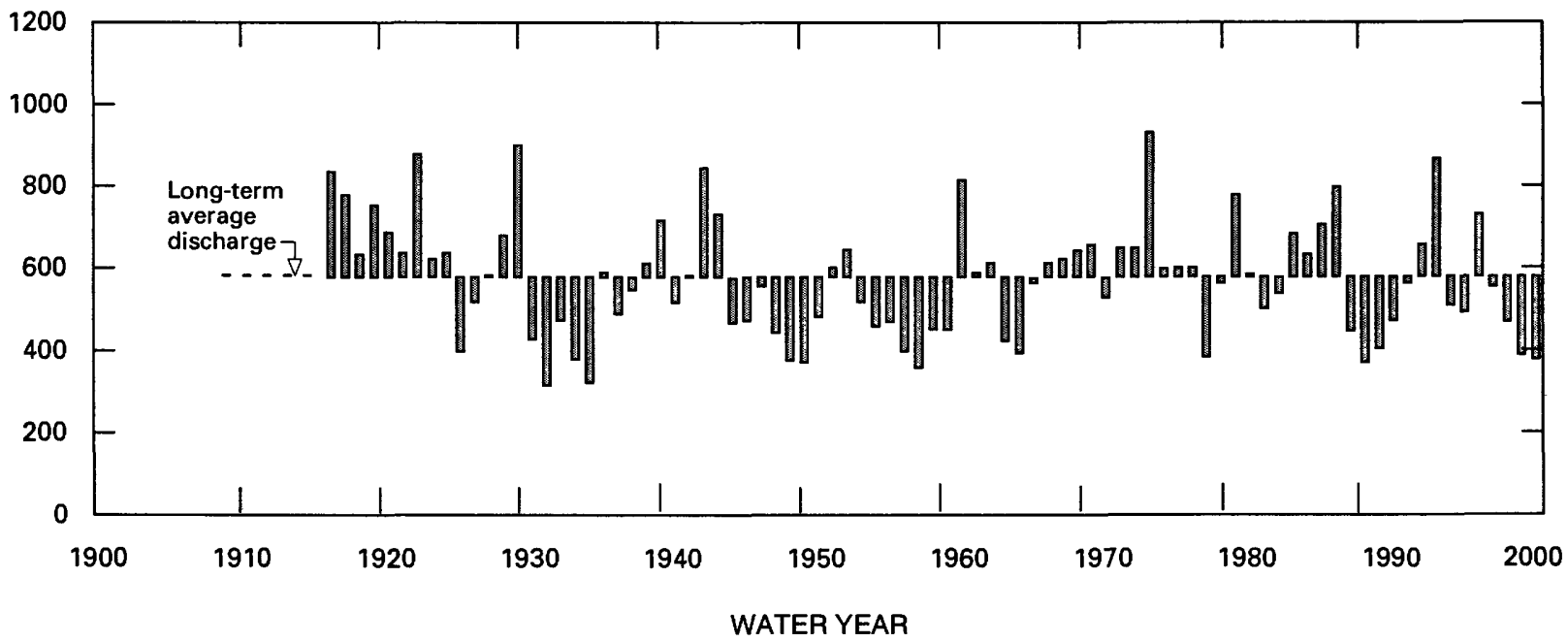

Figure 5. Comparison of annual discharge at representative gaging stations to their long-term average discharge for water years 1916-2000. 

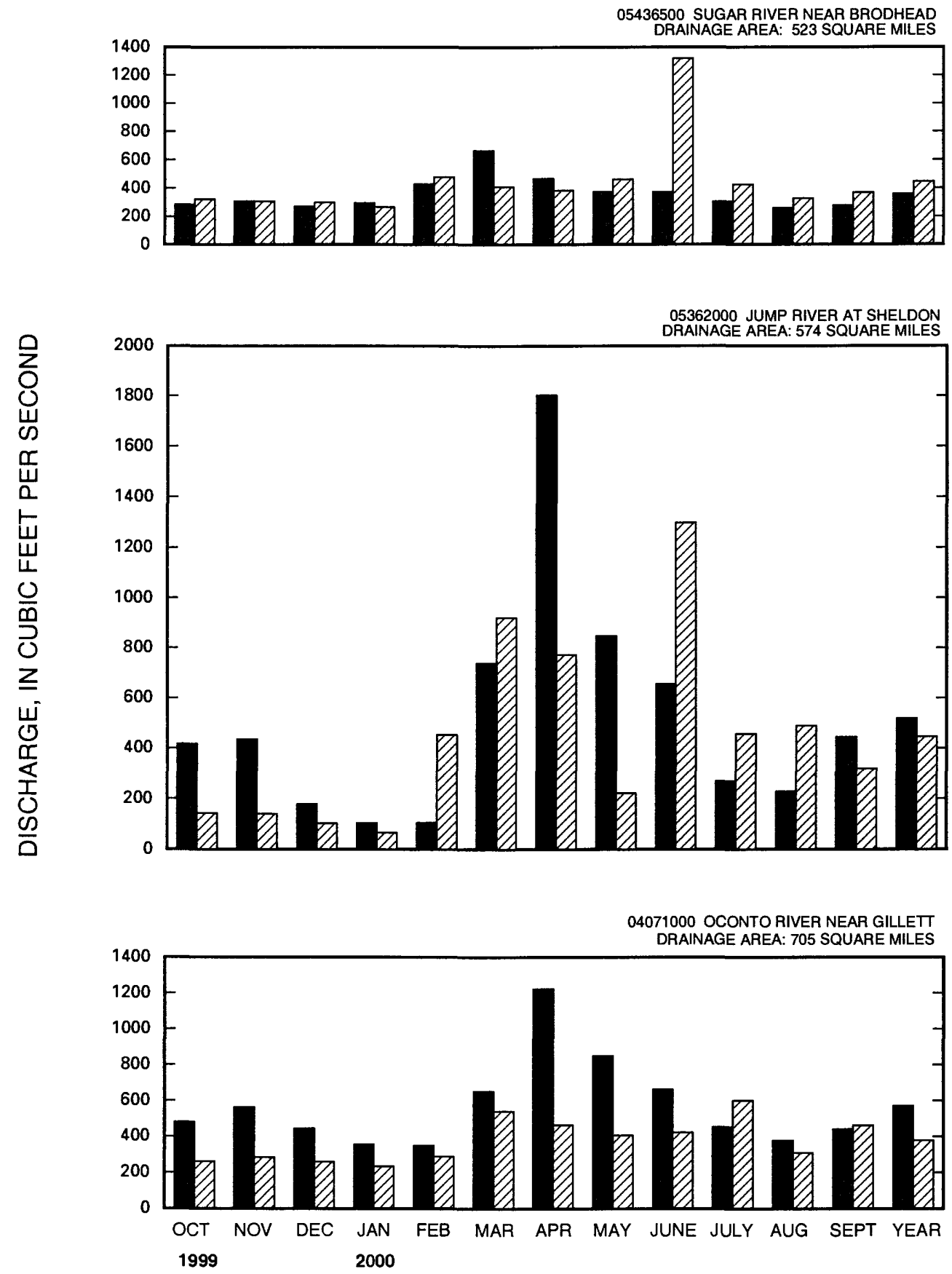

\section{EXPLANATION}

Long-term average monthly and long-term average annual discharge for 1916-2000

Monthly and annual discharge for 2000 water year

Figure 6. Comparison of discharge at representative gaging stations during water year 2000 with discharge for 1916-2000. 
Low flows occurred at 4 gaging stations where the annual minimum 7-consecutive day average flows (Q7) had recurrence intervals of 5 or more years. An additional 10 stations had Q7 flows with recurrence intervals that were between 2 and 5 years. Precipitation continued below normal in October through December of 1999 throughout Wisconsin, following the dry months of August and September. This resulted in the Q7 values which approached or exceeded the 5-year recurrence interval at a number of stations in north central, northeast and southeastern Wisconsin, generally in December. Below normal precipitation totals occurred again in August and September 2000 in northwest and west central Wisconsin (Lyle Anderson, State Climatology Office, University of Wisconsin, Madison, written commun., 2001). The Q7 values and recurrence intervals for gaging stations that equalled or exceeded 5 years are listed in the following table:

\begin{tabular}{rllcc}
\hline $\begin{array}{c}\text { Station } \\
\text { number }\end{array}$ & \multicolumn{1}{c}{ Station name } & Date & Q7 (ft $3 / \mathrm{s}$ ) & $\begin{array}{c}\text { Recurrence interval } \\
\text { (years) }\end{array}$ \\
\hline 04085200 & Kewaunee River near Kewaunee & Dec. 21 & 9.0 & 5 \\
04087159 & $\begin{array}{l}\text { Kinnickinnic River at South 11th Street at } \\
\text { Milwaukee }\end{array}$ & Jan. 23 & 4.2 & 5 \\
05360500 & Flambeau River near Bruce & Dec. 18 & 485 & 6 \\
05369500 & Chippewa River at Durand & Dec. 18 & 2260 & 8 \\
\hline
\end{tabular}

Runoff from frequent heavy rains in mid May to early June caused flooding throughout southern Wisconsin. Much of southern Wisconsin had sustained flooding caused by heavy rains May 17-19 and May 27 through June 2 (National Oceanic and Atmospheric Administration, May and June, 2000). Many areas in west central, central, east central, southwest, south central, and southeastern Wisconsin received more than 5 inches of rain during May. Areas in the southwest, south central, and southeastern parts received more than 10 inches, and as much as 18 inches of rain in this period (Rusty Kapela, National Weather Service, Milwaukee/Sullivan, written commun., July 13, 2000). Madison set a record for the wettest May in history with a total of 9.63 inches, 307 percent of normal (Wisconsin State Journal, June 1, 2000). Flooding was widespread from fast-moving lines of severe thunderstorms accompanied by high winds and some tornadoes: flooding was less severe on larger streams, but severe locally on smaller streams where discharges had recurrence intervals that exceeded 25 years (Krug and others, 1991). The sustained rainfall caused recordhigh water levels and closed county boat landings on the Yahara chain of lakes in Dane County. Lake Mendota set a new record-high water level on June 5, 2000, beating the old record set in 1993 (Wisconsin State Journal, June 7, 2000), and which exceeded the 100-year recurrenee interval. Lake Monona also rose to a new record on June 14 after 2.2 inches of rain, beating the former record set in 1996 and the highest level since records began in 1915. By mid June, monthly rainfall in Madison totalled 6.63 inches, 390 percent of normal, and flood damages in Dane County alone amounted to over $\$ 11$ million (Capital Times, June 14, 2000). Governor Thompson requested federal disaster assistance for damages totalling over $\$ 28$ million caused by severe storms and floods in 16 southern and central Wisconsin Counties (Wisconsin State Journal, June 24,2000 ). Statewide, more than 400,000 acres of cropland in 40 counties were damaged by excessive rain (Wisconsin State Journal, June 27, 2000).

More isolated severe storms in July, August and September also caused floods with discharges that equalled or exceeded those with a recurrence interval of 10 years or more (Krug and others, 1991). Thunderstorms during the month of July caused flooding in 6 southeastern counties and 2 northwestern counties. Monthly rainfall totals for July exceeded 12 inches in Burnett County (315 percent of normal) and 10 inches in Oneida County (Brian Hahn, National Weather Service, Milwaukee/Sullivan, written commun., September 6, 2000). Intense rainfall in Rusk and Sawyer Counties in the northwest in mid August exceeded the 100year 3-hour precipitation value of 3.8 inches (Huff and Angel, 1992). Over 8 inches of rain on September 10-11 in Eau Claire (Wisconsin State Journal, September 12, 2000) exceeded the 100-year 24-hour precip- 
itation value of about 6.5 inches. Chippewa Falls received a total of 10.48 inches for September, the maximum in the State and 257 percent of normal.

Peak discharges at stations which had recurrence intervals that equalled or exceeded 10 years are summarized in the following table:

\begin{tabular}{|c|c|c|c|c|c|}
\hline $\begin{array}{l}\text { Station } \\
\text { number }\end{array}$ & Station name & $\begin{array}{l}\text { Drainage area } \\
\quad\left(\mathrm{mi}^{2}\right)\end{array}$ & Date & $\begin{array}{l}\text { Peak discharge } \\
\left(\mathrm{ft}^{3} / \mathrm{s}\right)\end{array}$ & $\begin{array}{c}\text { Recurrence } \\
\text { interval } \\
\text { (years) }\end{array}$ \\
\hline 04077400 & Wolf River near Shawano & 816 & July 10 & 4020 & 20 \\
\hline 04087100 & Honey Creek at Milwaukee & 3.26 & July 2 & 1850 & $>500$ \\
\hline 04087200 & Oak Creek near South Milwaukee & 13.8 & July 2 & 1360 & $>500$ \\
\hline 04087250 & Pike Creek near Kenosha & 7.25 & June 12 & 235 & 45 \\
\hline 04087159 & Kinnickinnic River at Milwaukee & 18.8 & July 2 & 6170 & 10 \\
\hline 04087204 & Oak Creek at South Milwaukee & 25.0 & July 2 & 1120 & 40 \\
\hline 04087220 & Root River near Franklin & 49.2 & July 3 & 2420 & 14 \\
\hline 04087233 & Root River Canal near Franklin & 57.0 & July 3 & 1300 & 25 \\
\hline 04087257 & Pike River near Racine & 38.5 & June 12 & 1580 & 94 \\
\hline 05364100 & Seth Creek near Cadott & 3.25 & Sep. 11 & 774 & 85 \\
\hline 05371800 & Buffalo River Tributary near Osseo & 1.44 & July 8 & 136 & 18 \\
\hline 05382200 & French Creek near Ettrick & 14.3 & June 1 & 2450 & 30 \\
\hline 05392350 & Bearskin Creek near Harshaw & 31.1 & July 10 & 165 & 100 \\
\hline 05405000 & Baraboo River near Baraboo & 609 & June 2 & 5540 & 11 \\
\hline 05405600 & Rowan Creek at Poynette & 10.4 & June 1 & 975 & 17 \\
\hline 05407200 & Crooked Creek near Boscobel & 12.9 & June 1 & 1440 & 17 \\
\hline 05414213 & Little Platte River near Platteville & 79.7 & June 1 & 9200 & $>500$ \\
\hline 05414900 & Pats Creek near Elk Grove & 8.50 & June 1 & 6600 & 180 \\
\hline 05427948 & Pheasant Branch at Middleton & 18.3 & June 2 & 902 & 31 \\
\hline 05429500 & Yahara River near McFarland & 327 & June 5 & 681 & 23 \\
\hline 05430175 & Yahara River near Fulton & 518 & June 1 & 2260 & 10 \\
\hline 05543830 & Fox River at Waukesha & 126 & July 2 & 1730 & 18 \\
\hline 05548150 & N. Branch Nippersink Creek near Genoa City & 13.6 & June 12 & 563 & 500 \\
\hline
\end{tabular}

\section{References cited:}

Capital Times, Enough!: June14, 2000.

Huff, Floyd A. and Angel, James R., 1992, Rainfall Frequency Atlas of the Midwest: Midwestern Climate Center Research Report 92-03, Bulletin 71, p. 89. 
National Oceanic and Atmospheric Administration, 2000, Climatological data--Wisconsin, published monthly, Vol. 105, Number 5 and 6, 36 p.

Wisconsin Agricultural Statistics Service, 2000, Wisconsin Crop Weather: U. S. Department of Agriculture, Wisconsin Agricultural Statistics Service, Madison, Wis., 5 p.

Wisconsin State Journal, Here comes the rain again: June 1, 2000.

, Boating curbs put on bulging lakes: June 7, 2000.

, 12 counties qualify for federal disaster aid in wake of May storms: June 24, 2000.

, Rains left major crop damage: June 27, 2000.

, Storms and rain hit state hard; 1 dead: September 12, 2000.

Water Quality

Suspended-sediment yields for water year 2000 at two monitoring stations in southern Wisconsin showed suspended sediment yields in southwestern Wisconsin greater than long-term average and in southeastern Wisconsin yields were near the long-term average. The suspended-sediment yield at the Grant River at Burton in southwestern Wisconsin was 390 tons $/ \mathrm{mi}^{2}$ (tons per square mile), or 154 percent of the average annual yield for 1978-2000. The suspended-sediment yield for Jackson Creek Tributary near Elkhorn in southeastern Wisconsin for water year 2000 was 74 tons $/ \mathrm{mi}^{2}$, which was 101 percent of the average annual yield for the period 1984-2000. The total phosphorus yield for Jackson Creek Tributary was $404 \mathrm{lbs} / \mathrm{mi}^{2}$ (pounds per square mile), or 92 percent of the 1984-2000 annual average.

\section{Ground-Water Levels}

In general, shallow ground-water levels during the 2000 water year were normal to above normal for most of the wells in the southern part of the State. Wells in Door, Marathon, Polk, Vilas, and Waushara Counties had below normal ground-water levels at the beginning of the water year, and these levels remained below normal for the entire water year. The large extent of normal and above-normal ground-water levels can be attributed to near normal rainfall during the 2000 water year and normal rainfall during the previous water year. 


\section{COLLECTION OF BASIC RECORDS-SURFACE WATER, WI 00100}

\section{COOPERATORS:}

Bad River Band of Lake Superior Chippewa Indians

City of Barron

City of Beaver Dam

City of Fort Atkinson

City of Hillsboro

City of Peshtigo

City of Sparta

City of Thorp

City of Waupun

Dane County Department of Planning and Development Dane County Regional Planning Commission

Federal Energy Regulatory Commission Licensees

Black River Falls Municipal Utilities

Consolidated Paper Corporation, Niagara Division

Dairyland Power Cooperative

Northern States Power Company

Northwoods Hydropower

Wisconsin Electric Power Company

Wisconsin Public Service Corporation

Wisconsin Valley Improvement Company

Fontana/Walworth Water Pollution Control Commission

Green Bay Metropolitan Sewerage District

Illinois Department of Transportation

Jefferson County

Kickapoo Reserve

Lac du Flambeau Band of Lake Superior Chippewa

Madison Metropolitan Sewerage District

Menominee Indian Tribe of Wisconsin

Oneida Tribe of Indians of Wisconsin

Rock County Public Works Department

Southeastern Wisconsin Regional Planning Commission

Stockbridge-Munsee Band of Mohican Indians

U.S. Army Corps of Engineers

Village of Wittenberg

Walworth County Metropolitan Sewerage District

Wisconsin Department of Natural Resources

PROBLEM: Surface-water information is needed for surveillance, planning, design, hazard warning, operation, and management in water-related fields such as water supply, hydroelectric power, flood control, irrigation, bridge and culvert design, wildlife management, pollution abatement, flood-plain management, and water-resources development. An appropriate database is necessary to provide this information.

\section{LOCATION:}

Statewide

PROJECT CHIEF:

Robert J. Waschbusch

PERIOD OF PROJECT:

July 1913-Continuing

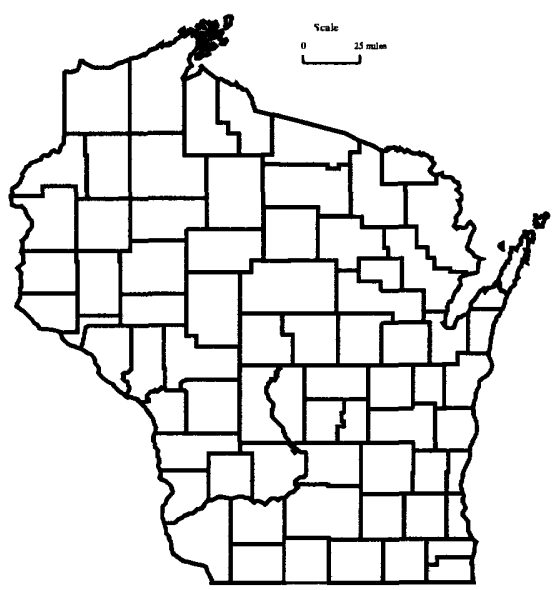


OBJECTIVE: The objectives of this study are to provide continuous discharge records for selected rivers at specific sites to supply the needs for regulation, analytical studies, definition of statistical properties, trends analysis, determination of the occurrence, and distribution of water in streams for planning. The project is also designed to determine lake levels and to provide discharge for floods, low-flow conditions, and for waterquality investigations. Requests for streamflow data and information relating to streamflow in Wisconsin are answered. Basic data are published annually in the report "Water Resources Data-Wisconsin".

APPROACH: A network of streamflow stations and lake-level stations will be maintained throughout Wisconsin. This includes operating the equipment at the gaging station to record river or lake stage, making periodic discharge measurements at each streamflow station to establish or verify a stage-discharge rating curve, reducing the stage records to instantaneous and daily discharges, compilation of monthly and annual discharges, and preparing data for publication in the annual report "Water Resources Data-Wisconsin".

Requests for streamflow data from other government agencies, consultants, and private parties will be processed.

PROGRESS (July 2000 to June 2001): During the current fiscal year, streamflow data were collected at a total of 110 sites: 18 sites for the Corps of Engineers, 14 sites for the Southeastern Wisconsin Regional Planning Commission, 12 sites for the Wisconsin Department of Natural Resources (WDNR), 9 sites for the USGS Federal program, 4 sites for Federal Energy Commission licensees, 3 sites for the Madison Metropolitan Sewerage District, 2 sites for the Lac du Flambeau Band of Lake Superior Chippewa, and 1 site each for the Bad River Band of Lake Superior Chippewa Indians, Menominee Indian Tribe of Wisconsin, Oneida Tribe of Indians of Wisconsin, Stockbridge-Munsee Band of Mohican Indians, Illinois Department of Transportation, Rock County Public Works Department, Fontana/Walworth Water Pollution Control Commission, Dane County Department of Planning and Development, Walworth County Metropolitan Sewerage District, Dane County Regional Planning Commission, Green Bay Metropolitan Sewerage District, Kickapoo Reserve, and cities of Barron, Beaver Dam, Fort Atkinson, Hillsboro, Peshtigo, Sparta, Thorp, Waupun, and village of Wittenberg. Streamflow data were also collected at 28 sites for agencies working jointly with the USGS. Lake-level data were collected at two sites for the Dane County Department of Planning and Development, two sites for the Corps of Engineers, one site for the Rock County Public Works Department, and one site for the WDNR.

A map showing the location of all continuous-record streamflow-gaging stations in Wisconsin is shown on page 5 .
Computation of streamflow and lake-level records for all the network stations for the 2000 water year was completed, stored in our NWIS computer database, and published in the annual report "Water Resources DataWisconsin, water year $2000^{\prime \prime}$. More than 300 requests for streamflow information were answered.

PLANS (July 2001 to June 2002): Data will be collected at 113 continuous-streamflow stations (see the following list) and lake levels at 6 stations. Streamflow records will be computed and data published for the 2001 water year. Requests for streamflow information will be answered.

\section{Real-time data can be accessed on the World Wide Web at http://wi.water.usgs.gov}

Station 05543800 Fox River at Waukesha was discontinued by the cooperator for 2001 . The USGS received funding under the Real-time Hazards Initiative program to install and operate three new stations during the year-

04073365 Fox River at Princeton, Wisconsin 05379400 Trempealeau River near Arcadia, Wisconsin 05407470 Kickapoo River at Ontario

and to continue operation of 05381000 Black River at Neillsville that was discontinued by the Corps of Engineers. 
SURFACE-WATER GAGING STATIONS EXPECTED TO BE OPERATED IN 2002 FY

\begin{tabular}{|c|c|c|c|c|}
\hline $\begin{array}{l}\text { Station } \\
\text { number }\end{array}$ & Name and location & $\begin{array}{c}\text { Drainage } \\
\text { Area }\end{array}$ & $\begin{array}{l}\text { Period of record } \\
\text { (water year) }\end{array}$ & Cooperator \\
\hline $\begin{array}{l}46464609205 \\
04024430 \\
04025500 \\
04027000\end{array}$ & $\begin{array}{l}52900 \text { Superior Bay, Duluth Ship Canal at Duluth, MN } \\
\text { Nemadji River - South Superior } \\
\text { Bois Brule River - Brule } \\
\text { Bad River - Odanah }\end{array}$ & $\begin{array}{r}4200 \\
420 \\
118 \\
597\end{array}$ & $\begin{array}{l}1994- \\
1974- \\
1943-81,1984- \\
1914-22,1948-\end{array}$ & $\begin{array}{l}\text { Cof E, Detroit } \\
\text { WDNR } \\
\text { USGS Federal Program } \\
\text { Bad River Band of Lake } \\
\text { Superior Chippewa Indians }\end{array}$ \\
\hline $\begin{array}{l}04027500 \\
04029990 \\
04063700 \\
04064500 \\
04065106 \\
04066003 \\
04066030 \\
04066500 \\
04066800\end{array}$ & $\begin{array}{l}\text { White River - Ashland } \\
\text { Montreal River - Saxon Falls } \\
\text { Popple River - Fence } \\
\text { Pine River - Pine River Powerplant - Florence } \\
\text { Menominee River - Niagara } \\
\text { Menominee River - Pembine } \\
\text { Menominee River - White Rapids Dam - Banat, Ml } \\
\text { Pike River - Amberg } \\
\text { Menominee River - Koss, Ml }\end{array}$ & $\begin{array}{r}301 \\
262 \\
139 \\
533 \\
2470 \\
3140 \\
3190 \\
255 \\
3700\end{array}$ & $\begin{array}{l}1948- \\
1987 \\
1964- \\
1924-76,1996- \\
1993- \\
1950- \\
1999- \\
1914-70,2000- \\
1907-09,1913-81, \\
1998-\end{array}$ & $\begin{array}{l}\text { NSPMDNR } \\
\text { NSPMWNR } \\
\text { USGS Federal Program } \\
\text { WEPCO/WDNR } \\
\text { FERC } \\
\text { WEPCO/WDNR } \\
\text { FERC } \\
\text { USGS Federal Program } \\
\text {, FERC }\end{array}$ \\
\hline 04067500 & Menominee River - McAllister & 3930 & $\begin{array}{l}1945-61,1979-86 \\
1988-90,1993-95\end{array}$ & $\begin{array}{l}\text { WDNR } \\
1998\end{array}$ \\
\hline 04067958 & Peshtigo River - Wabeno & 447 & 1998 & WPS/WDNR \\
\hline 04069416 & Peshtigo River - Porterfield & 1020 & $1998-$ & FERC \\
\hline 04069500 & Peshtigo River - Peshtigo & 1080 & 1953- & City of Peshtigo \\
\hline 04071000 & Oconto River - Gillett & 705 & $1906-09,1914-$ & USGS Federal Program \\
\hline 04071765 & Oconto River - Oconto & 966 & $1989-90,1998-$ & WDNR \\
\hline $\begin{array}{l}04072150 \\
04073365\end{array}$ & $\begin{array}{l}\text { Duck Creek - Howard } \\
\text { Fox River - Princeton }\end{array}$ & 108 & $\begin{array}{l}1988- \\
2001-\end{array}$ & $\begin{array}{l}\text { Oneida Tribe of Indians of WI } \\
\text { USGS Federal Program }\end{array}$ \\
\hline 04073500 & Fox River - Berlin & 1340 & 1898- & $C$ of $E$, Detroit \\
\hline 04074950 & Wolf River - Langlade & 463 & $1966-79,1981-$ & Menominee Indian Tribe of WI \\
\hline 04077400 & Wolf River - Shawano & 816 & $1907-09,1911-$ & Wolf River Hydro/WDNR \\
\hline 04077630 & Red River - Morgan & 114 & 1993 & $\begin{array}{l}\text { Stockbridge-Munsee Band of } \\
\text { Mohican Indians }\end{array}$ \\
\hline 0407809265 & Middle Branch Embarrass River - Wittenberg & 76.3 & 1990- & Village of Wittenberg \\
\hline 04078500 & Embarrass River - Embarrass & 384 & $1919-85,1994$ & USGS Federal Program \\
\hline 04079000 & Wolf River - New London & 2260 & 1896- & $C$ of $E$, Detroit \\
\hline 04082400 & Fox River - Oshkosh & 5310 & 1991 & $C$ of $E$, Detroit \\
\hline 04084445 & Fox River - Appleton & 5950 & 1986- & C of E, Detroit \\
\hline 04084500 & Fox River - Rapide Croche Dam - Wrightstown & 6010 & 1896- & LFRDAWDNR \\
\hline 040851385 & Fox River - Oil Tank Depot - Green Bay & 6330 & $1989-$ & Green Bay MSD \\
\hline 04085200 & Kewaunee River - Kewaunee & 127 & $1964-96,1998-$ & WDNR \\
\hline 04085395 & S.Br. Manitowoc River - Hayton & 109 & 1993- & WDNR \\
\hline 04085427 & Manitowoc River - Manitowoc & 526 & $1972-96,1998-$ & WDNR \\
\hline 04086000 & Sheboygan River - Sheboygan & 418 & $1916-24,1951$ & WDNR \\
\hline 04086500 & Cedar Creek - Cedarburg & 120 & $\begin{array}{l}1930-70,73-81 \\
1983-87,1991\end{array}$ & WDNR \\
\hline 04086600 & Milwaukee River - Pioneer Road - Cedarburg & 607 & 1982- & SEWRPC \\
\hline 04087000 & Milwaukee River - Milwaukee & 696 & 1914- & SEWRPC \\
\hline 04087030 & Menomonee River - Menomonee Falls & 34.7 & $1975-77,1979-$ & SEWRPC \\
\hline 04087088 & Underwood Creek - Wauwatosa & 18.2 & $1975-$ & SEWRPC \\
\hline 04087120 & Menomonee River - Wauwatosa & 123 & $1962-$ & SEWRPC \\
\hline 04087160 & Kinnickinnic River - Milwaukee & 20.4 & 1976- & SEWRPC \\
\hline 04087204 & Oak Creek - South Milwaukee & 25 & $1964-$ & SEWRPC \\
\hline 04087220 & Root River - Franklin & 49.2 & 1964- & SEWRPC \\
\hline 04087233 & Root River Canal - Franklin & 57 & $1964-$ & SEWRPC \\
\hline 04087240 & Root River - Racine & 190 & $1963-$ & SEWRPC \\
\hline 04087257 & Pike River - Racine & 38.5 & $1972-$ & SEWRPC \\
\hline 05332500 & Namekagon River - Trego & 488 & $1928-70,1988$ & NSPMDNR \\
\hline 05340500 & St. Croix River - St. Croix Falis & 6240 & $1902-$ & NSPMDNR \\
\hline 05341500 & Apple River - Somerset & 579 & $1901-70,1987$ & NSP/WDNR \\
\hline 05356000 & Chippewa River - Winter & 790 & $1912-$ & NSPMDNR \\
\hline 05356500 & Chippewa River - Bruce & 1650 & $1914-$ & NSP/WDNR \\
\hline 05357254 & Trout River - CTH H - Boulder Junction & 58.9 & 1999- & $\begin{array}{l}\text { Lac du Flambeau Band of Lake } \\
\text { Superior Chippewa (LDF) }\end{array}$ \\
\hline 05357335 & Bear River - Manitowish Waters & 81.3 & 1991 & LDF \\
\hline 05360500 & Flambeau River - Bruce & 1860 & $1951-$ & NSPWDNR, FERC \\
\hline 05362000 & Jump River - Sheldon & 576 & $1915-$ & USGS Federal Program \\
\hline 05365500 & Chippewa River - Chippewa Falls & 5650 & $1888-1983,1987$ & NSPMDNR \\
\hline 05365707 & North Fork Eau Claire River - Thorp & 51 & 1986 & City of Thorp \\
\hline 053674464 & Yellow River - Barron & 153 & 1991 & City of Barron \\
\hline 05368000 & Hay River - Wheeler & 418 & 1951 & USGS Federal Program \\
\hline 05369000 & Red Cedar River - Menomonie & 1770 & $1907 \cdot 08,1913$ & NSPMDNR \\
\hline 05369500 & Chippewa River - Durand & 9010 & 1928- & C of E, St. Paul \\
\hline 05370000 & Eau Galle River - Spring Valley & 64.1 & 1944 & C of E, St. Paul \\
\hline 05379400 & Trempealeau River - Arcadia & 606 & $1960-77,2001-$ & USGS Federal Program \\
\hline $\begin{array}{l}05379500 \\
05381000\end{array}$ & $\begin{array}{l}\text { Trempealeau River - Dodge } \\
\text { Black River - Neillsville }\end{array}$ & $\begin{array}{l}643 \\
749\end{array}$ & $\begin{array}{l}1914-19,1934 \\
1905-09,1914-\end{array}$ & $\begin{array}{l}\text { C of E, St. Paul } \\
\text { C of E, St. Paul }\end{array}$ \\
\hline
\end{tabular}




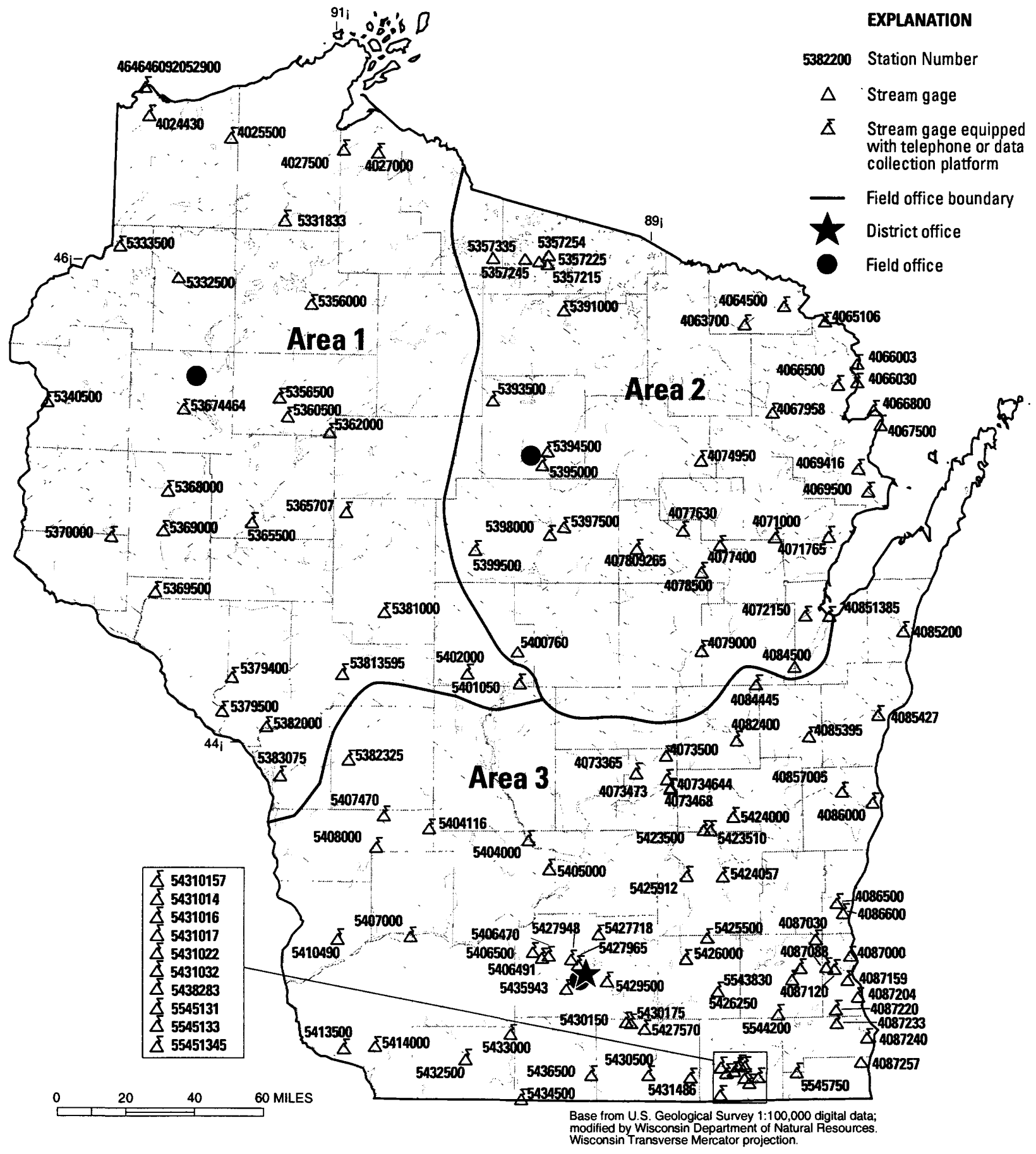

Figure 7. Location of continuous-record data-collection stations. 


\section{DISCONTINUED SURFACE-WATER DISCHARGE STATIONS}

The following continuous-record surface-water discharge stations in Wisconsin have been discontinued. Daily streamflow records were collected and published for the period of record, expressed in water years, shown for each station. Those stations with an asterisk $\left(^{*}\right)$ after the station number are currently operated as crest-stage partial-record stations. Some of the discontinued project stations with less than three years of record have not been included. Information regarding these stations may be obtained from the District Office at the address given on the back side of the title page of this report.

\section{Discontinued surface-water discharge stations}

\section{Station name}

$\begin{array}{ll}\text { Station } & \text { Drainage area } \\ \text { number } & \text { (square miles) }\end{array}$

STREAMS TRIBUTARY TO LAKE SUPERIOR

Little Balsam Creek at Patzau, WI

Little Balsam Creek near Patzau, WI

Little Balsam Creek Tributary near Patzau, WI

Little Balsam Creek near Foxboro, WI

Amnicon River near Poplar (Amnicon Falls), WI

Bois Brule (Brule) River near Brule, WI

Sioux River near Washbum, WI

Pine Creek at Moquah, WI

Pine Creek Tributary at Moquah, WI

Pine Creek near Moquah, WI

North Fish Creek near Moquah, WI

Bad River near Mellen, WI

Bad River at Meilen, WI

Alder Creek near Upson, WI

Montreal River near Kimball, WI

West Fork Montreal River at Gile, WI

West Fork Montreal River near Kimball, WI

04024314
04024315
04024318
04024320
04025000
04026000
$04026300^{\star}$
04026347
04026348
04026349
040263491
$04026450^{\star}$
04026500
04026870
04028500
04029000
04029500

\subsection{9}

5.05

0.60

3.27

110

160

33.9

6.20

0.48

19.9

65.4

82.0

98.3

22.2

100

75.0

86.2
Period of record

STREAMS TRIBUTARY TO LAKE MICHIGAN

North Branch Pine River at Windsor Dam near Alvin, WI

Pine River near Florence, WI

Pine River below Pine River Power Plant near Florence, WI

Peshtigo River at High Falls near Crivitz, WI

Pensaukee River near Pensaukee, WI

Suamico River at Suamico, WI

Lawrence Creek near Westfield, WI

Grand Aiver near Kingston, WI

West Branch White River near Wautoma, WI

White Creek at Forest Glen Beach near Green Lake, WI

Swamp Creek above Rice Lake at Mole Lake, WI

Swamp Creek below Rice Lake at Mole Lake, WI

Wolf River near White Lake, WI

Evergreen Creek near Langlade, WI

Wolf River above West Branch Wolf River, WI

West Branch Wolf River at Neopit, WI

West Branch Wolt River near Keshena, WI

Little Wolf River near Galloway, WI

Spaulding Creek near Big Falis, WI

Little Wolf River at Royalton, WI

Emmons Creek near Rural, WI

Storm Sewer to Mirror Lake at Waupaca, WI

Waupaca River near Waupaca, WI

Daggets Creek at Butte Des Morts, WI

West Branch Fond du Lac River at Fond du Lac, WI

East Branch Fond du Lac River near Fond du Lac, WI

Brothertown Creek at Brothertown, WI

East Twin River at Mishicot, WI

Onion River at Hingham, WI

Onion River near Sheboygan Falls, WI

Milwaukee River at Kewaskum, WI

East Branch Milwaukee River near New Fane, WI $04063640^{\star}$

04064000

04064500

04068000

04071858

04072000

04072750

04073050

04073405

04073462

04074538

04074548

04075000

$04075200^{*}$

04075500

04076000

04076500

04079602

$04079700^{*}$

04080000

04080950

04080976

04081000

04081800

04083000

04083500

04084200

04085281

04085813

04085845

04086150

04086200
27.8

510

533

537

134

60.7

13.4

73.5

38.9

3.05

46.3

56.8

485

8.09

616

93.2

163

22.6

5.57

507

25.1

0.04

265

10.6

83.1

78.4

5.10

110

37.2

94.1

138

54.1
1976-78

1976-78

1976-78

1977-78

1914-16

1914-17

1965-66

1976-78

1976-78

1976-78

1990-91

1971-75

1948-55

1972-77

1924-26

1918-26, 1943-47

1924-26
1967-68

1914-23

1924-76

1912-57

1973-96

1951-52

1968-73

1968-75

1964-75

1982-88

1977-83, 1985-87

$1977-79,1982-85$

1935-38

1964-73

1928-62

1911-17

1928-32

1974-79

1964-66

$1914-70,1983-85$

1977

1971-74

$1916-66,1983-85$

1977

1939-54

1939-54

1976-77

1972-96

$1979-80$

1979-82

1968-81

1968-81 
Discontinued surface-water discharge stations

\begin{tabular}{|c|c|c|c|}
\hline Station name & $\begin{array}{l}\text { Station } \\
\text { number }\end{array}$ & $\begin{array}{l}\text { Drainage area } \\
\text { (square miles) }\end{array}$ & Period of record \\
\hline North Branch Milwaukee River near Fillmore, WI & 04086340 & 148 & $1968-81$ \\
\hline Milwaukee River at Waubeka, WI & 04086360 & 432 & $1968-81,1994$ \\
\hline Mud Lake Outlet near Decker Corner, WI & 04086488 & 7.36 & $1983-84$ \\
\hline Milwaukee River above North Ave. Dam at Milwaukee, WI & 04087010 & $1982-84$ & \\
\hline Menomonee River at Germantown, WI & 04087018 & 19.0 & $1975-77$ \\
\hline $\begin{array}{l}\text { Jefferson Park Drainageway at Germantown, WI } \\
\text { Menomonee River at Butler, WI }\end{array}$ & $\begin{array}{l}04087019 \\
04087040\end{array}$ & $\begin{array}{l}1.82 \\
60.6\end{array}$ & $\begin{array}{l}1976-78 \\
1975-79\end{array}$ \\
\hline Little Menomonee River near Freistadt, WI & $04087050^{*}$ & 8.0 & $1975-79$ \\
\hline Noyes Creek at Milwaukee, WI & 04087060 & 1.94 & $1975-80,1990$ \\
\hline Little Menomonee River at Milwaukee, WI & 04087070 & 19.7 & $1975-77$ \\
\hline Honey Creek at Wauwatosa, WI & 04087119 & 10.3 & $1975-81$ \\
\hline Schoonmaker Creek at Wauwatosa, WI & 04087125 & 1.94 & $1975-79$ \\
\hline Hawley Road Storm Sewer at Milwaukee, WI & 04087130 & 1.83 & $1975-77$ \\
\hline Menomonee River at Milwaukee, WI & 04087138 & 134 & $1982-84$ \\
\hline Kinnickinnic River at Milwaukee, WI & 04087160 & 20.4 & $1976-83$ \\
\hline
\end{tabular}

\section{ST. CROIX RIVER BASIN}

Namekagon River at Trego, WI

Loon Creek near Danbury, WI

Bashaw Brook near Shell Lake, WI

Clam River near Webster, WI

St. Croix River near Grantsburg, WI

Wood River near Grantsburg, WI

Rice Creek near Balsam Lake, WI

Balsam Branch at Balsam Lake, WI

Kinnickinnic River near River Falls, WI

05332000
05335010
$05335380^{\star}$
05335500
05336000
05339000
05341375
05341402
05342000

CHIPPEWA RIVER BASIN

West Fork Chippewa River at Lessards, near Winter, WI

Couderay River near Couderay, WI

Flambeau River near Buttemut, WI

Pine Creek near Oxbo, WI

Flambeau River at Babbs Island near Winter, WI

South Fork Flambeau River near Phillips, WI

Price Creek near Phillips, WI

Flambeau River near (at) Ladysmith, WI

Chippewa River near Holcombe, WI

South Fork Jump River near Ogema, WI

Chippewa River at Holcombe, WI

Fisher River at (near) Holcombe, WI

O'Neil Creek near Chippewa Falls, WI

Yellow River near Hannibal, WI

Yellow River at Cadott, WI

Duncan Creek at Bloomer, WI

Duncan Creek Tributary near Tilden, WI

Duncan Creek at Chippewa Falls, WI

Eau Claire River near Augusta, WI

Bridge Creek at Augusta, WI

Eau Claire River near Fall Creek, WI

Chippewa River at (near) Eau Claire, WI

Red Cedar River near Cameron, WI

Red Cedar River near Cameron, WI

Red Cedar River near Colfax, WI

Eau Galle River near Woodville, WI

Eau Galle River at low water bridge at Spring Valley, WI

French Creek near Spring Valley, WI

Lousy Creek near Spring Valley, WI

Lohn Creek near Spring Valley, WI

Eau Galle River at Elmwood, WI

05355500

05356121

05358000

05358300

05358500

05359500

05359600*

05360000

05361000

05361500

05362500

05363000

05363500

05363700

$05364000^{*}$

05364500*

05364850

05365000

05366000

05366300

05366500*

05367000

05367425

05367426

05367500

05369900

05369945

05369955

05369970

05369985

05370500

433
17.6
26.6
361
2,980
185
12.5
52.8
165

1914-27

1970-71

1964-66

1941-42

1923-70

1939-40

1988-89

1988-90

1917-21
1912-16

1981-83

1927-61

1914-39

1971-75

1929-75

1929-75

1964-66

1903-06, 1914-61

1944-49

1944-54

1943-49

1944-45

1944-45

1962-63

1943-61

1944-52

1987-89

1943-55

1914-26

1980

1943-55

1903-09, 1944-54

1966-70

1971-73

1914-80, 1989-90

1978-83

$1982-83,1986-96$

1981-83

1981-83

1981-83

1943-54

\section{BUFFALO RIVER BASIN}




\section{Discontinued surface-water discharge stations}

\begin{tabular}{llll}
\hline Station name & $\begin{array}{l}\text { Station } \\
\text { number }\end{array}$ & $\begin{array}{l}\text { Drainage area } \\
\text { (square miles) }\end{array} \quad$ Period of record
\end{tabular}

TREMPEALEAU RIVER BASIN

Bruce Valley Creek near Pleasantville, WI Elk Creek near Independence, WI

Trempealeau River near Trempealeau, WI

Black River at Medford, WI

Poplar River near Owen, WI

Little LaCrosse River near Leon, WI

LaCrosse River near West Salem, WI

Spring Coulee Creek near Coon Valley, WI

Coon Creek at Coon Valley, WI

Coon Creek near Stoddard, WI

North Fork Bad Axe River near Genoa, WI
05379288
05379305

05380000

\section{BLACK RIVER BASIN}

05380806

$05380900^{*}$

48.1

155

\section{LA CROSSE RIVER BASIN}

05382500

05383000

76.9

396

\section{COON CREEK BASIN}

05386490
05386500

05386999

9.01

77.2

120

\section{BAD AXE RIVER BASIN}

$05387100^{*}$

80.8

\section{WISCONSIN RIVER BASIN}

Wisconsin River at Conover, WI

Pelican River near Rhinelander, WI

Wisconsin River at Whirlpool Rapids, near Rhinelander, WI

05390180

05391226

Bearskin Creek near Harshaw, WI

Tomahawk River near Bradley, W

Tomahawk River at Bradley, WI

New Wood River near Merrill, WI

Rib River at Rib Falls, WI

Little Rib River near Wausau, WI

East Branch Eau Claire River near Antigo, WI

Eau Claire River near Antigo, WI

Bull Junior Creek (Bull Creek Junior) near Rothschild, WI

Big Eau Pleine River near Colby, W

Hamann Creek near Stratford, WI

Wisconsin River at Knowlton, W

Plover River near Stevens Point, WI

Little Plover River near Arnott, WI

Little Plover River at Plover, WI

Fourmile Creek near Kellner, WI

Buena Vista Creek near Kellner, WI

Tenmile Creek Ditch 5 near Bancroft, WI

Fourteenmile Creek near New Rome, WI

Wisconsin River near Necedah, WI

Big Roche a Cri Creek near Hancock, WI

Big Roche a Cri Creek near Adams, WI

Yellow River at Sprague, WI

Yellow River at Necedah, W

Lemonweir River at New Lisbon, W

Hulbert Creek near Wisconsin Dells, WI

Dell Creek near Lake Delton, W

Narrows Creek at Loganville, W

Wisconsin River at Prairie du Sac, WI

05392000

$05392350^{*}$

05392400

05393000

05394000

05396000

05396500

05397000

05397110

05398500

05399000

05399431

05400000

05400500

05400600

05400650

05400840

05400853

05401020

05401100

05401500

05401510

05401535

05402500

05403000

05403500

05403630 *

$05403700^{*}$

$05404200^{*}$

05406000

Trout Creek at Confluence with Arneson Creek near Barneveld, WI 05406573

Trout Creek at Twin Parks Dam 8 near Barneveld, WI

05406574

05406575

05406577

05406590

05406640

05408500

05409000

Otter Creek near Highland, WI

Knapp Creek near Bloomingdale, WI

West Fork Kickapoo River near Readstown, WI

05409500
177

101

1,220

31.1

422

544

82.2

303

79.1

81.5

185

27.4

78.1

11.3

4,530

145

2.24

19.0

75.0

53.1

9.73

91.1

5,990

9.61

528

392

491

507

11.2

44.9

40.1

9,180

8.371976-78

9.02

12.1

13.5

7.57

16.8

8.44

106

530
1980

1980

1932-34

1984-87

1964-66

$1934-61,1979-81$ 1914-70

1979-81

1934-40, 1978-81

$1934-40,1979-81$

1964-66

1967-7

1976-79

1906-61

1964-66

1915-27, 1929

$1930-73$

1953-61

1925-57

1914-16

1949-55

1975-81

1944-52

1941-54

1977-79

1921-42

1914-20, 1944-52

1959-75

1959-87

1964-67

1964-67

1964-73

1964-79

$1903-14,1944-50$

1964-67

1964-78

1927-40

1941-57

1944-87, 1994

1971-77

1957-65, 1971-80

1964-66

1946-54

1976-79

1976-78

1976-79

1976-78

1968-69, 1970-75

1955-69

1939

1939 


\section{Discontinued surface-water discharge stations}

Station name
Station

number
Drainage area

(square miles)

Period of record

North Fork Nederlo Creek near Gays Mills, WI

Kickapoo River at Gays Mills, WI

Pigeon Creek near Lancaster, WI

Rattlesnake Creek near Beetown, WI
Nederlo Creek near Gays Mills, WI

05409830

05409890

05410000

\section{GRANT RIVER BASIN}

$05413400^{*}$

05413451

6.93

45.2

\section{GALENA RIVER BASIN}

Little Platte River near Platteville, WI Sinsinawa River near Hazel Green, WI Pats Creek near Belmont, WI

Madden Branch Tributary near Belmont, WI

Madden Branch near Meekers Grove, WI

Galena River at Buncombe, WI

Apple River near Shullsburg, WI

West Branch Rock River near Waupun, WI

West Branch Rock River at County Trunk Highway D near Waupun, WI

East Branch Rock River near Mayville, WI

Rock River at Hustisford, WI

Johnson Creek near Johnson Creek, WI

Johnson Creek near Johnson Creek, WI

Pratt Creek near Juneau, WI

Rock River at Jefferson, WI

Whitewater Creek near Whitewater, WI

Whitewater Creek at Millis Road near Whitewater, WI

Whitewater Creek at Whitewater, WI

Koshkonong Creek near Rockdale, WI

Token Creek near Madison, WI

Sixmile Creek near Waunakee, WI

05414213
05414800
05414894
$05414915^{\star}$
05414920
05415000

79.7

24.9

5.42

2.83

15.04

125

\section{APPLE RIVER BASIN}

$$
05418731
$$

\section{ROCK RIVER BASIN}

05423000
05423100
05424000
05424082
05425537
05425539
05425928
05426031
05426500
05426900
05427000
05427507
$05427800^{*}$
05427900
05427943

40.7

43.9

179

511

1.13

13.3

3.54

1,850

11.8

20.6

22.8

150

24.3

41.1

9.61

5.74

20.8

24.5

3.15

2.57

0.23

2.30

6.00

15.3

430

9.93

41.9

41.3

8.96

16.4

28.5

944

5.9

32.6

35.0

32.7

16.4
1981-82

1968-79

1968-80

1914-34, 1964-77

1964-66

1990-91

1987-90

1987-90

1981-82

1981-82

1981-82

1939-92

$1949-70,1978-81$

1978-81

1949-70

1978-85

1978-80

1978-80

1978-80

1978-94

1926-28, 1946-54

1978-81

1926-28, 1946-54

1977-82

1964-66, 1976-81

1976-82

1977-81

1978-81

1977-81

1978-81

1974-83

1976-80

1971-77

1972-77

1971-77

1976-79

1917-18

1979-81

1956-66, 1986-88

1956-66

1984-95

1987-91

1954-65, 1978-79

1914-19

1978-79

1978-81

1978-81

1979-80

1954-65, 1976-80

\section{ILLINOIS RIVER BASIN}




\section{COLLECTION OF BASIC RECORDS-GROUND WATER, WI 00200}

\section{COOPERATOR:}

Wisconsin Geological and Natural History Survey

\section{LOCATION:}

Statewide

\section{PROJECT CHIEF:}

Bernard R. Ellefson

PERIOD OF PROJECT:

July 1946-Continuing

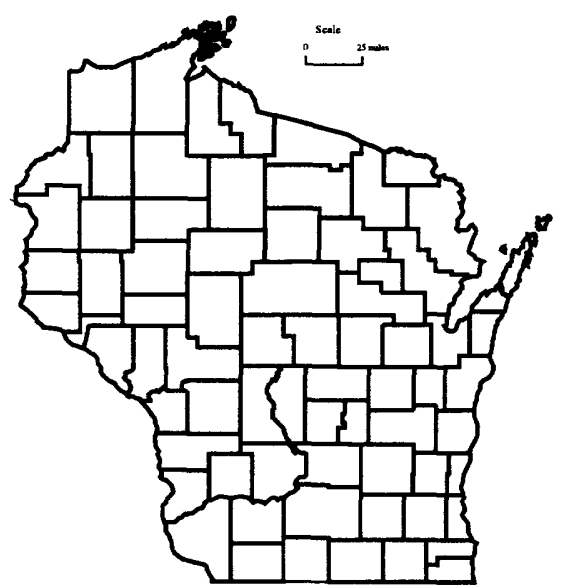

PROBLEM: Ground-water data are needed to determine shortterm changes and long-term trends in ground-water levels in the State. It is important to know if these changes are natural or maninduced and how these changes are affecting storage in the groundwater reservoirs.

OBJECTIVE: The objective is to maintain records of groundwater level fluctuations from a network of observation wells representative of Wisconsin's principal aquifers.

APPROACH: A basic network of about 126 wells is being maintained. The network will be constantly modified and improved to provide the best possible coverage of our ground-water resource. A subnetwork of key wells are included in this network. Key wells have long periods of record and are measured weekly or are equipped with continuous recorders.

PROGRESS (July 2000 to June 2001): Routine data collection and data being collected by observers is evaluated and entered into the database. Three replacement wells were drilled to replace the ones that were plugged. Water-level data for the annual report, "Water Resources Data-Wisconsin, water year 2000" was completed.

PLANS (July 2001 to June 2002): Plans include: (1) continue measurements on the observation-well network, (2) replace and hire new observers and make quality-assurance checks when possible, (3) data evaluation and preparation for the annual report, (4) install real-time data collection equipment on three wells in the network, and (5) update water levels at selected wells and make them available on the internet at http://wi.water.usgs.gov.

\section{REPORTS:}

Patterson, G.L., and Zaporozec, A., 1988, Analysis of water-level fluctuations in Wisconsin wells: Wisconsin Geological and Natural History Survey Information Circular 63.

Erickson, R.M., and Cotter, R.D., 1983, Trends in ground-water levels in Wisconsin through 1981: Wisconsin Geological and Natural History Survey Information Circular No. 43.

Erickson, R.M., 1972, Trends in ground-water levels in Wisconsin, 1967-71: Wisconsin Geological and Natural History Survey Information Circular No. 21.

Devaul, R.W., 1967, Trends in ground-water levels in Wisconsin through 1966: Wisconsin Geological and Natural History Survey Information Circular No. 9. 


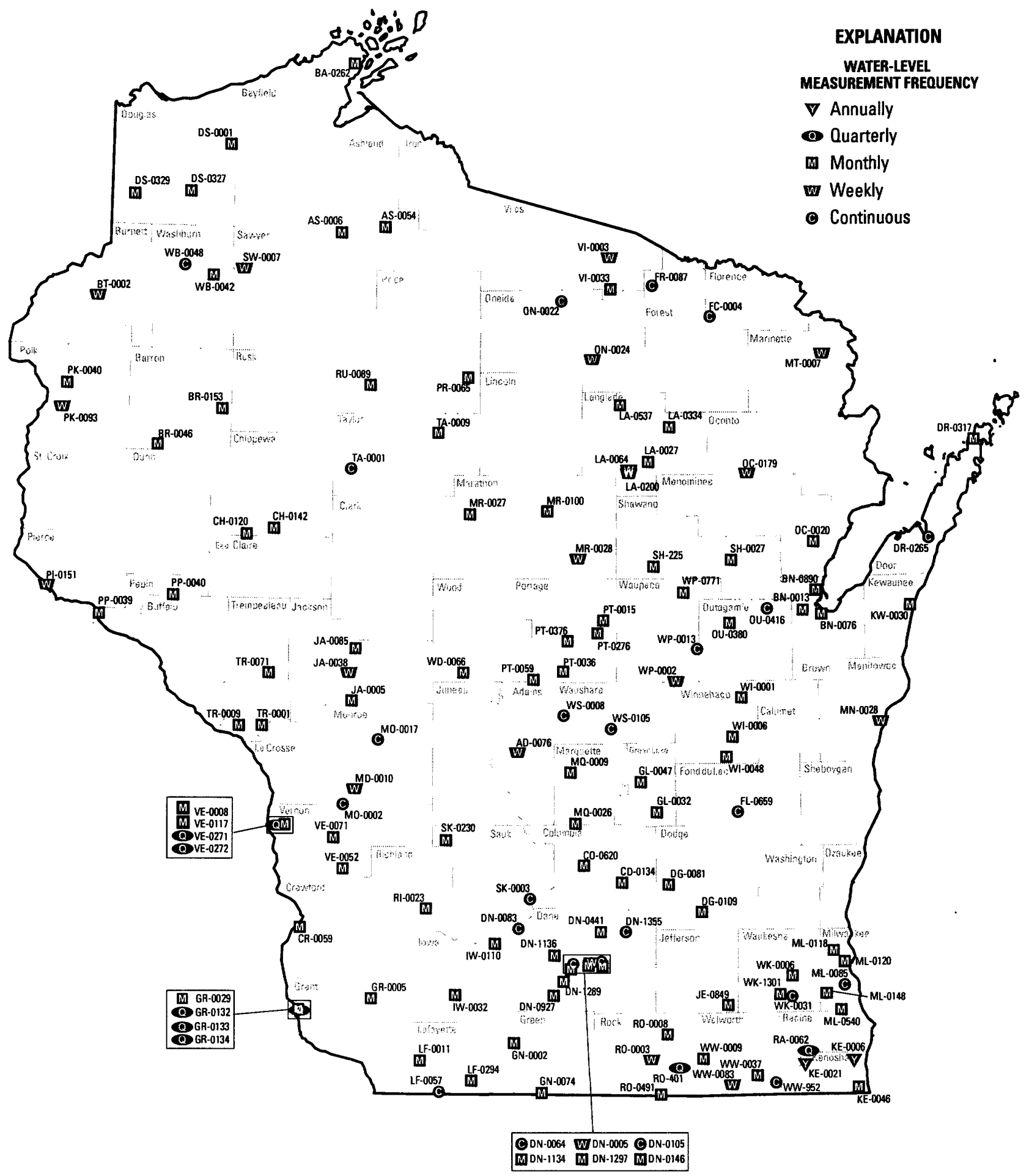

Figure 8. Location of network observation wells. 


\section{CRANDON GROUND WATER, WI 00201}

COOPERATOR:

Wisconsin Department of

Natural Resources

LOCATION:

Forest County

PROJECT CHIEF:

James T. Krohelski

PERIOD OF PROJECT:

October 1994-Continuing

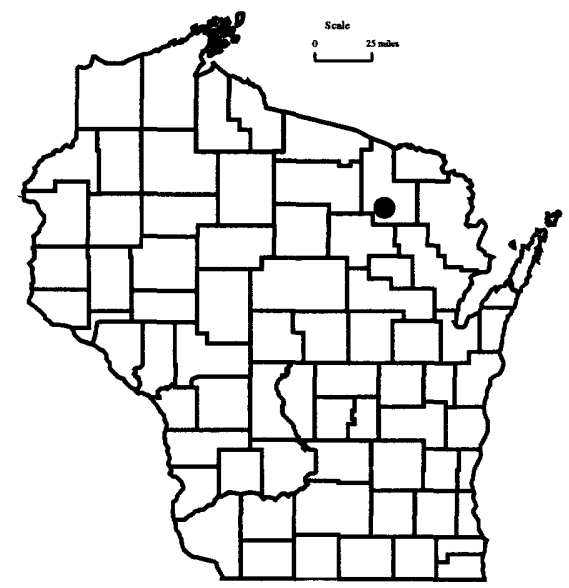

PROBLEM: A large underground zinc-copper mine is being proposed at a site about five miles south of Crandon, Wisconsin, in Forest County. The Wisconsin Department of Natural Resources (WDNR) requested that District staff review the development of a ground-water-flow model and associated hydrologic documents as part of a permitting process for the proposed mine.

OBJECTIVE: The objective is to review documents related to water resources submitted to WDNR from the Crandon Mining Company (CMC) and their consultants and to make suggestions to WDNR on studies and approaches that will improve the understanding of the hydrology and effects of mining on the water resources in the vicinity of the proposed mine.

APPROACH: The schedule for review of documents will be mutually agreed upon between WDNR and USGS.

PROGRESS (July 2000 to June 2001): Calibration of the ground-water-flow model is completed. Predictive simulations, based on the calibrated ground-water model are complete. A review of the TMA contaminant transport was initiated. Monitoring of lake stage and shallow ground-water levels adjacent to Little Sand Lake and Skunk Lake was continued.

PLANS (July 2001 to June 2002): Documents will be reviewed and meetings attended at the request of the WDNR. Descriptions of model development, calibration and simulation results of the flow and contaminant transport models will be summarized and submitted to the WDNR. Monitoring of lake stage and shallow ground-water levels adjacent to Little Sand Lake will be continued. 


\section{COLLECTION OF BASIC RECORDS-DANE COUNTY PROGRAM, WI 00302}

PROBLEM: A long-term base of water-quality data is needed for water-resource planning and assessment of water quality in the lakes and streams of Dane County.

OBJECTIVE: The objectives of this program are to determine suspended-sediment and phosphorus loads of selected tributaries to Lake Mendota and to collect data to identify long-term changes in base-flow water quality in selected streams in Dane County.

APPROACH: Streamflow-monitoring stations with automatic water-quality samplers are operated on three tributaries to Lake Mendota. Samples for analysis of suspended-sediment and phosphorus concentrations are collected at low flow and during periods when surface runoff is entering the streams. The concentration and streamflow data are used to compute annual suspended-sediment and totalphosphorus loads for the three stations. Various water-quality constituents are measured six times during the year at base flow of selected streams in the county.

PROGRESS (July 2000 to June 2001): Streamflow and water-quality data collection at three continuous-record monitoring sites (Pheasant Branch at Middleton, Spring Harbor Storm Sewer at Madison, and Yahara River at Windsor) continued. Suspendedsediment loads were computed for Spring Harbor Storm Sewer and suspended-sediment and total-phosphorus loads were computed for the Yahara River and Pheasant Branch for the 2000 water year. Continuous-streamflow monitoring at Black Earth Creek near Black Earth was continued for the year.

Base-flow water-quality sampling was completed for Six Mile Creek near Waunakee, Mt. Vernon Creek near Mt. Vernon, Door Creek near Cottage Grove, and Yahara River near Stoughton in November 2000. Base-flow sampling will begin at a new set of four streams in the county for 2001. All streamflow, load and concentration data were published in the annual data report "Water Resources Data-Wisconsin, Water Year 2000."

PLANS (July 2001 to June 2002): Streamflow monitoring will be continued at Black Earth Creek and streamflow and waterquality monitoring will be continued at the three continuous-record stations on tributaries to Lake Mendota. Six base-flow water-quality samples will be collected from Pheasant Branch at Highway 12 in Middleton, Token Creek near Madison, East Branch and West Branch Starkweather Creek at Madison during the calendar year (starting in spring 2001). Final data will be prepared and published in the annual data report, "Water Resources Data-Wisconsin, Water Year 2001".

\section{COOPERATOR:}

Dane County Regional Planning

Commission

LOCATION:

Dane County

PROJECT CHIEF:

Herbert S. Garn

PERIOD OF PROJECT:

Continuing

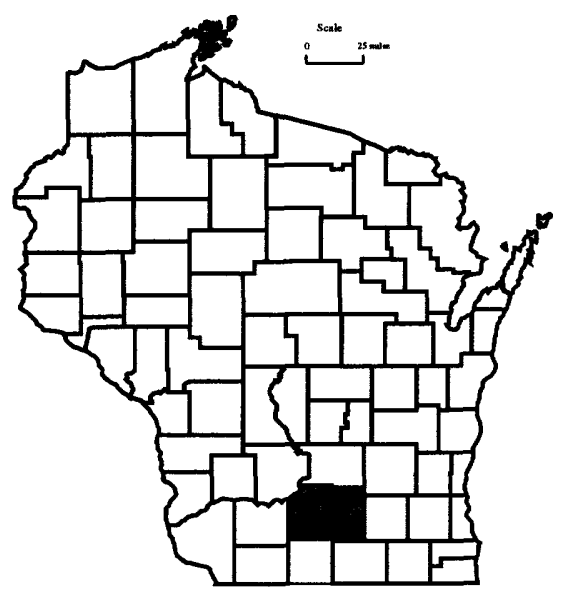




\section{INTERAGENCY METHODS AND DATA COMPARABILITY BOARD (MDCB), WI 00303}

\section{COOPERATOR:}

\author{
U.S. Geological Survey
}

LOCATION:

Comprised of individuals from throughout the United States

PROJECT CHIEF:

Charles A. Peters

PERIOD OF PROJECT: April 1998 to September 2001
PROBLEM: Significant resources are spent to monitor water quality in the United States. The methods used to collect water samples and to analyze the samples collected vary between the collecting authority. The data obtained using the various methods may not be comparable and therefore each monitoring entity may collect duplicate data.

OBJECTIVE: A nationwide partnership of water-monitoring authorities from Federal and State agencies, tribes, municipalities, business and industry, academia, and others with expertise in environmental monitoring has been assembled to coordinate and provide guidance for implementation of a voluntary, integrated, nationwide monitoring strategy that will provide comparable data.

APPROACH: The MDCB holds quarterly meetings to discuss the progress and plans of work groups formed to develop consensus positions regarding issues related to sampling and analytical approaches. The seven work groups (Performance Based Systems, National Environmental Methods Index, Laboratory Accreditation and Field Certification, Biological Methods, Nutrient Methods, Water Quality Data Elements, and Publicity and Outreach) establish work plans and meet via conference calls and at the quarterly MDCB meetings to accomplish work plan objectives.

PROGRESS (July 2000 to June 2001): A co-chair is responsible for maintaining a public website, developing work plans, organizing meetings and conference calls, preparing meeting minutes, assisting with the preparation of position papers and pilot studies, preparing outreach products, and providing guidance for and participating in other MDCB activities. The co-chair also participates as a member of the National Water Quality Monitoring Council (NWQMC) and as a member of the NWQMC steering committee.

PLANS (July 2001 to June 2002): The co-chair will continue to maintain a public website, develop work plans, organize meetings and conference calls, prepare meeting minutes, assist with the preparation of position papers and pilot studies, prepare outreach products, and provide guidance for and participate in other MDCB activities. 


\section{AGE DATING GROUND WATER IN ATRAZINE PROHIBITION AREAS IN WISCONSIN, WI 00304}

PROBLEM: The Wisconsin Department of Agriculture, Trade and Consumer Protection (DATCP) will be monitoring groundwater quality from 63 wells at 21 locations in Wisconsin to determine if atrazine can be safely reintroduced in atrazine prohibition areas. The wells will be monitored for a five- or six-year period in order to detect changes in atrazine concentrations in ground water. It will be necessary to determine the age of the sampled ground water to show that the five- or six-year sampling period is long enough to show the effects of atrazine reuse on shallow ground-water quality.

OBJECTIVE: The objective of this project is to determine the age of the ground water that will be sampled in the atrazine reuse areas. The data collected for this study will be used to determine whether the planned five- or six-year monitoring period is sufficient to show the effects of atrazine reuse on shallow ground-water quality.

APPROACH: The U.S. Geological Survey (USGS), Wisconsin District will use chlorofluorocarbons (CFCs) to determine the age of shallow ground water from one well at each of the 21 locations chosen by DATCP. CFC samples will be collected, analyzed, and ground-water ages determined using procedures and equipment developed by the USGS.

PROGRESS (July 2000 to June 2001): Additional monitor wells, installed by DATCP, were sampled for CFCs and dissolved gas. Ground-water ages were estimated and results were presented to DATCP.

PLANS: Project is complete.
COOPERATOR:

Wisconsin Department of Agriculture, Trade and Consumer Protection

\section{LOCATION:}

Statewide

\section{PROJECT CHIEF:}

David A. Saad

PERIOD OF PROJECT: June 1998 to September 2000

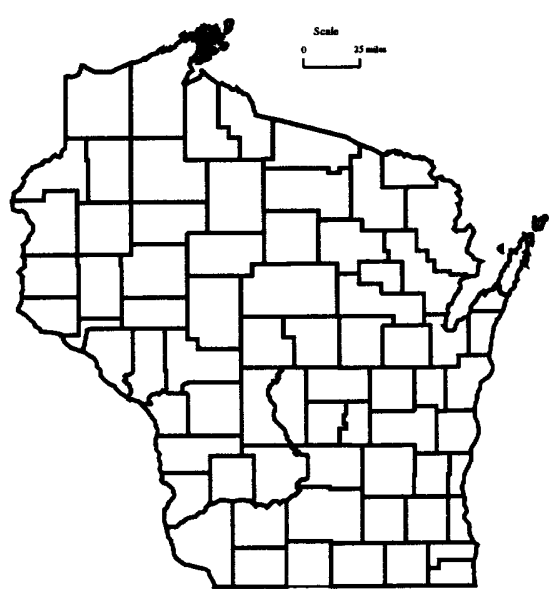




\section{GROUND-WATER AGE DATING IN THE LITTLE PLOVER RIVER BASIN, WISCONSIN, WI 00351}

\author{
COOPERATOR: \\ University of Wisconsin-Stevens \\ Point
}

\section{LOCATION:}

Portage County

\section{PROJECT CHIEF:}

David A. Saad

PERIOD OF PROJECT:
July 1997 to September 2000
PROBLEM: The Little Plover River Basin is in one of the most highly productive irrigated agricultural regions of the Midwest United States. It has been the focus of studies relating to land use, hydrology, and water quality for over 30 years. The UW-Stevens Point, College of Natural Resources, is trying to develop a way of using data from the ground-water/surface-water interface in the basin to obtain a synoptic historical view of land-use and water-quality relations at the watershed scale. Determination of ground-water ages at the ground-water/surface-water interface would provide useful information for understanding ground-water flow in the basin and for linking water quality with historic land uses.

OBJECTIVE: The objective of this study is to estimate age of ground water at the ground-water/surface-water interface at approximately 100 locations in the basin.

APPROACH: Ground-water ages will be estimated using chlorofluorocarbons (CFCs). CFCs will be collected from existing nearand in-stream networks of minipiezometers. CFC samples will be collected and analyzed using procedures and equipment developed by the USGS.

PROGRESS (July 2000 to June 2001): Ten CFC and 20 dissolved gas samples were collected from mini-piezometers located in the streambed of the Little Plover River. Samples were analyzed by the CFC lab in Reston. Ten sulfur hexaflouride (SF6) and 20 N20 samples were also collected. SF6 samples were to be used for comparison to CFC age-dating method; however, all 10 samples were contaminated relative to atmospheric concentrations. Geologic materials underlying the basin may be a possible source of SF6. N20 results indicate that denitrification is occurring at most of the sampled locations.

PLANS: Project is complete.

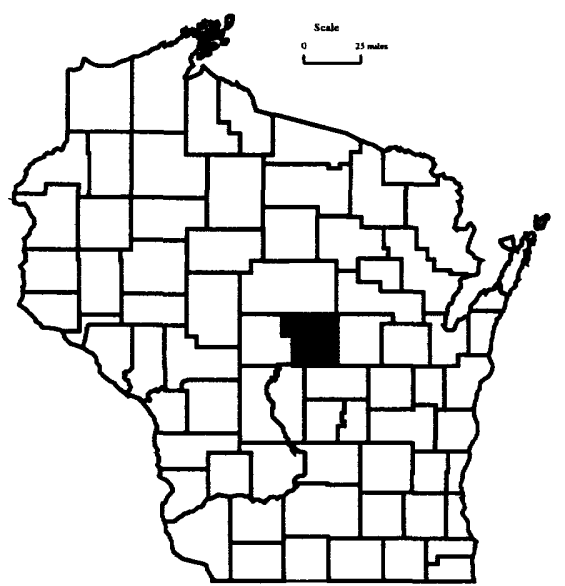




\section{COLLECTION OF BASIC RECORDS-SEDIMENT, WI 00400}

PROBLEM: Water-resources planning and water-quality assessment require a knowledge of the quantity and quality of sediment being transported in rivers and streams in Wisconsin.

OBJECTIVE: This project will provide sediment data for use in specific planning and action programs and will develop a database for determining trends in sediment discharge and yield. Streams will be characterized according to range of concentration and particle size of suspended sediment.

APPROACH: Sediment-monitoring stations will be operated at selected stream sites throughout the State, including sites of specific interest to cooperating agencies.

The extent of monitoring at a given site will depend on the characteristics of the basin and the needs of the cooperating agency. Some sites will be sampled manually at infrequent intervals; other sites, where flow responds rapidly to precipitation, will be sampled by automatic samplers.

At sites where bedload or unmeasured sediment discharge may be a significant part of the total sediment discharge, suspended- and bedsediment particle size will be determined from samples collected concurrently with hydraulic data. These data will be used to estimate total sediment discharge using one of several techniques such as the modified Einstein procedure.

PROGRESS (July 2000 to June 2001): Sediment data have been collected at more than 200 stream sites in Wisconsin since 1968. All data have been published annually in the data report, "Water Resources Data-Wisconsin". The 2001 monitoring program is as follows:

CORPS OF ENGINEERS-Suspended sediment was sampled at the Grant River at Burton. Daily loads were determined from these data.

PLANS (July 2001 to June 2002):

CORPS OF ENGINEERS-Operation of the Grant River monitoring station will continue.

Efforts to secure cooperative funding to establish a long-term sediment-monitoring network will continue. About 10 sites areally distributed to sample runoff from the major geographic provinces would provide an adequate network.

\section{REPORTS:}

Rose, William J., and Graczyk, David J., 1996, Sediment transport, particle size, and loads in North Fish Creek in Bayfield County, Wisconsin, water years 1990-91, U.S. Geological Survey Water-Resources Investigations Report 95-4222, 18 p.

Rose, William J., 1992, Sediment transport, particle sizes, and loads in the lower reaches of the Chippewa, Black, and Wisconsin Rivers in western Wisconsin, U.S. Geological Survey WaterResources Investigations Report 90-4124, 38 p.
COOPERATORS:

U.S. Army Corps of Engineers

LOCATION:

Statewide

PROJECT CHIEF:

William J. Rose

PERIOD OF PROJECT:

March 1968-Continuing

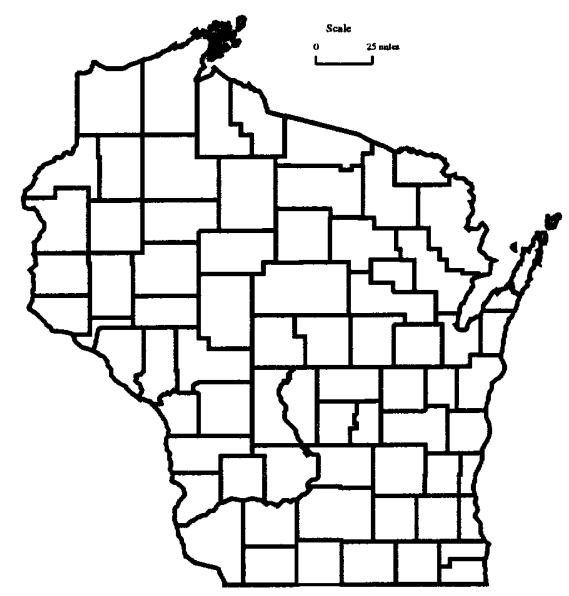




\section{WISCONSIN WATER-USE DATA FILE, WI 00700}

COOPERATOR:

Wisconsin Department of Natural Resources

LOCATION:

Statewide

PROJECT CHIEF:

Bernard R. Ellefson

PERIOD OF PROJECT:

March 1978-Continuing

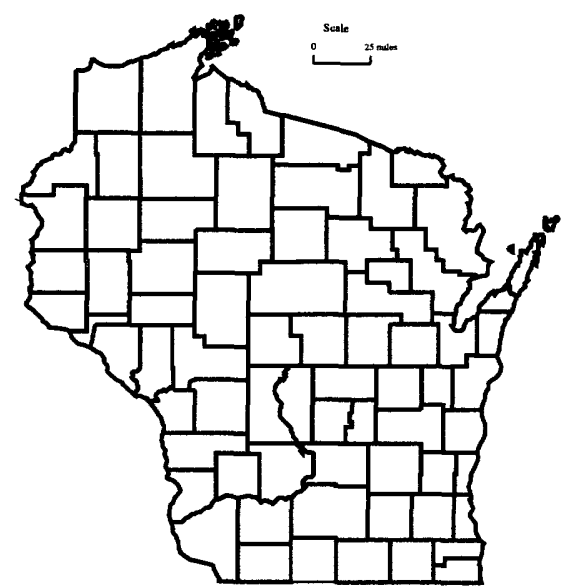

PROBLEM: The need for reliable water-use data by State and Federal planning agencies is increasing as the competition for use of the State's water resources increases. Water-use data in a standardized format needs to be available to assist in making decisions on future water use.

OBJECTIVE: The purpose of this project is to collect accurate and complete data on Wisconsin's water use, store data in the State Water-Use Data System (SWUDS), and prepare periodic reports on water use in the State.

APPROACH: Sources of water-use information will be evaluated. The best available data will be entered into SWUDS. Efforts will be made to upgrade the accuracy of the water-use data.

PROGRESS (July 2000 to June 2001): SWUDS was updated with current water-use information as it became available. These data included high-capacity well data and information on discharge from sewage- treatment plants in the State. Reformatting programs were written or updated as needed for entering data from other agencies into SWUDS. Data collection for the 2000 water-use summary was started.

PLANS (July 2001 to June 2002): Plans include: (1) continue to update and maintain SWUDS with current water-use data; (2) supply water-use data for water-resources studies currently being conducted in the State; and (3) work with Department of Natural Resources and Wisconsin Geological and Natural History Survey in a joint effort to establish a water-use database that can be used and updated by each agency. Data collection and estimates will be completed and the report, "Water Use in Wisconsin, 2000" will be prepared for publication.

\section{REPORTS:}

Ellefson, B.R., Fan, C.H., and Ripley, J.L., 1995, Water use in Wisconsin, 1995: U.S. Geological Survey Open-File Report 97-356, 1 sheet, scale 1:5,000,000.

Ellefson, B.R., Sabin, T.J., Krohelski, J.T., 1993, Water use in Wisconsin, 1990: U.S. Geological Survey Open-File Report 93118,1 sheet, scale 1:5,000,000.

Ellefson, B.R., Rury, K.S., and Krohelski, J.T., 1988, Water-use in Wisconsin, 1985: U.S. Geological Survey Open-File Report 87-699, 1 sheet, scale 1:5,000,000.

U.S. Geological Survey, 1990, National Water Summary, 1987Hydrologic events and water supply and use: U.S. Geological Survey Water-Supply Paper 2350, $553 \mathrm{p}$.

Krohelski, J.T., Ellefson, B.R., and Storlie, C.A., 1987, Estimated use of ground water for irrigation in Wisconsin, 1984: U.S. Geological Survey Water-Resources Investigations Report $86-4079,12 \mathrm{p} ., 1 \mathrm{pl}$.

Lawrence, C.L., and Ellefson, B.R., 1984, Public-supply pumpage in Wisconsin, by aquifer: U.S. Geological Survey Open-File Report 83-931, $40 \mathrm{p}$.

1982, Water use in Wisconsin, 1979: U.S. Geological Survey Open-File Report 82-444, 98 p. 


\section{REGIONAL FLOOD-FREQUENCY STUDY FOR URBAN AND RURAL STREAMS IN WISCONSIN, WI 10900}

PROBLEM: Flood-frequency estimates are required at many sites for bridge and culvert design, as well as for flood-plain management and flood-insurance studies. Most sites at which such estimates are required do not have records of flood peaks.

OBJECTIVE: Objectives are to (1) operate a State-wide network of crest gages to obtain ongoing information on flood peaks; (2) develop improved regression equations for the State of Wisconsin; and (3) analyze and improve the network of crest-stage gages to obtain better data for developing improved regression equations.

APPROACH: A network of approximately 100 crest-stage gages will be maintained to gather flood peak information, especially on streams with small drainage areas. The information on annual flood peaks will be used to compute flood-frequency at these sites. Periodically, the expanded information on flood frequency at streams throughout the State will be used to compute regional floodfrequency equations to estimate flood frequency at ungaged sites.

PROGRESS (July 2000 to June 2001): Annual flood peaks were computed and published in the annual data report for 79 creststage stations, including 13 new stations. New stations have been installed in areas where the cooperator indicated the greatest need for more information on flooding. Significant effort has been made in measuring flood discharges at crest gages, especially at the newly installed gages, and improving ratings at crest gages. Flood frequency has been recalculated using data through water year 1998.

PLANS (July 2001 to June 2002): The crest-stage-gage network will be monitored throughout the year. Ratings will be developed for more new gages as measurements and surveys are available. Significant effort will be made to improve ratings at all the gages. Work will begin on recalculating regression equations for computing flood frequency.

\section{REPORTS:}

Krug, W.R., 1996, Simulation of temporal changes in rainfall-runoff characteristics, Coon Creek Basin, Wisconsin: Journal of the American Water Resources Association, v. 32, no. 4, p. 745752.

Krug, W.R., Conger, D.H., and Gebert, W.A., 1992, Floodfrequency characteristics of Wisconsin streams: U.S. Geological Survey Water-Resources Investigations Report 91-4128, 185 p., 2 pls.

Conger, D.H., 1986, Estimating magnitude and frequency of floods for Wisconsin urban streams: U.S. Geological Survey WaterResources Investigations Report 86-4005, $18 \mathrm{p}$.

Conger, D.H., 1981, Techniques for estimating magnitude and frequency of floods for Wisconsin streams: U.S. Geological Survey Water-Resources Investigations Open-File Report 80-1214, 116 p., 2 pls.

Conger, D.H., 1971, Estimating magnitude and frequency of floods in Wisconsin: U.S. Geological Survey Open-File Report, 200 p.

\section{COOPERATOR:}

City of Fond du Lac

Wisconsin Department of Transportation

\section{LOCATION:}

Statewide

PROJECT CHIEF:

William R. Krug

PERIOD OF PROJECT: July 1985-Continuing

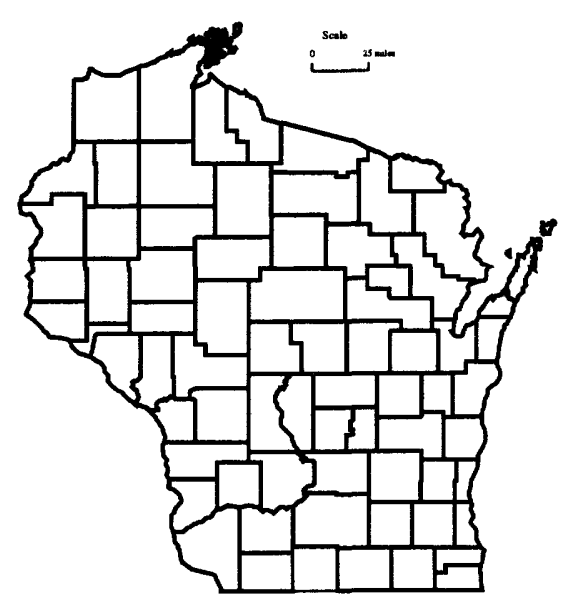




\section{LIST OF CREST-STAGE GAGES}

\section{CHIPPEWA RIVER BASIN}

05357360

05359600

05361400

05361420

05361989

05363775

05364000

05364100

05364500

05366500

05367030

053674588

05367700

05370900

\section{CENTRAL WISCONSIN RIVER BASIN}

$\begin{array}{ll}05395020 & \text { Lloyd Creek near Doering, WI } \\ 05395100 & \text { Trappe River Tributary near Merrill, WI } \\ 05396300 & \text { Wisconsin River Tributary at Wausau, WI } \\ 05397600 & \text { Big Sandy Creek near Wausau, WI } \\ 05400025 & \text { Johnson Creek near Knowlton, WI } \\ 05401800 & \text { Yellow River Tributary near Pittsville, WI } \\ 05403397 & \text { Allen Creek at Canary Drive near Oakdale, WI } \\ 05403700 & \text { Dell Creek near Lake Delton, WI }\end{array}$

\section{FOX-WOLF RIVER BASIN}

04072792 Tagatz Creek near Westfield, WI

04073066

04073400

04074850

04075200

04079700

04081900

Grand River tributary near Manchester, W

Bird Creek at Wautoma, WI

Lily River near Lily, WI

Evergreen Creek near Langlade, WI

Spaulding Creek near Big Falls, WI

Sawyer Creek at Oshkosh, WI

\section{LAKE MICHIGAN BASIN}

04078891

04085145

04085400

040854105

04086310

04087100

04087200

04087250

Maple Creek near Sugar Bush, WI

Red River at CTH A near Dyckesville, WI

Killsnake River near Chilton, WI

Mud Creek at Marken Road near Valders, W

Mink Creek at CTH S near Beechwood, WI

Honey Creek at Milwaukee, WI

Oak Creek near South Milwaukee, WI

Pike Creek near Kenosha, WI

\section{LAKE SUPERIOR BASIN}

$\begin{array}{ll}04024400 & \text { Stony Brook near Superior, WI } \\ 04025200 & \text { Pearson Creek near Maple, WI } \\ 04026200 & \text { Sand River Tributary near Red Cliff, WI } \\ 04026300 & \text { Sioux River near Washburn, WI } \\ 04026450 & \text { Bad River near Mellen, WI } \\ 04027200 & \text { Pearl Creek at Grandview, WI }\end{array}$

\section{LOWER WISCONSIN RIVER BASIN}

$\begin{array}{ll}05405600 & \begin{array}{l}\text { Rowan Creek at Poynette, WI } \\ \text { Otter Creek at Kings Corner Road } \\ \text { near Prairie du Sac, WI } \\ \text { Lowery Creek near Spring Green, WI }\end{array} \\ 05406605 & \begin{array}{l}\text { Fancy Creek near Gillingham, WI } \\ 05406754\end{array} \\ 05406854 & \text { Willow Creek at CTH D near Loyd } \\ 05407039 & \begin{array}{l}\text { Fennimore Fork near Fennimore, WI } \\ 05407200\end{array} \\ \text { Crooked Creek near Boscobel, WI }\end{array}$

05413060 Martin Branch near Mount Ida, WI

05409270 Reads Creek at Riley Road near Readstown, WI

\section{MENOMINEE-OCONTO-PESHTIGO RIVER BASIN}

$\begin{array}{ll}04059900 & \text { Allen Creek Tributary near Alvin, WI } \\ 04063640 & \begin{array}{l}\text { North Branch Pine River at Windsor Dam near } \\ \text { Alvin, WI }\end{array} \\ 04067760 & \begin{array}{l}\text { Peshtigo River near Cavour, WI } \\ 04069700\end{array} \\ \text { North Branch Oconto River near Wabeno, WI } \\ 04071700 & \text { North Branch Little River near Coleman, WI } \\ 04071800 & \text { Pensaukee River near Pulaski, WI }\end{array}$

PECATONICA-SUGAR RIVER BASIN

$\begin{array}{ll}05413400 & \text { Pigeon Creek near Lancaster, WI } \\ 05414213 & \text { Little Platte River near Platteville, WI } \\ 05414900 & \text { Pats Creek near Elk Grove, WI } \\ 05432055 & \text { Livingston Branch near Livingston, WI } \\ 05432300 & \text { Rock Branch near Mineral Point, WI } \\ 05433500 & \text { Yellowstone River near Blanchardville, WI } \\ 05436200 & \text { Gill Creek near Brooklyn, WI }\end{array}$

\section{ROCK-FOX RIVER BASIN}

\section{Gill Creek at Farmersville, WI}

$05425806 \quad$ Mud Creek near Danville, WI

05430403 Fisher Creek Tributary at Janesville, WI

$05431400 \quad$ Little Turtle Creek at Allens Grove, WI

05545100 Sugar Creek at Elkhorn, WI

05545200 White River Tributary near Burlington, WI

$05548150 \quad$ North Branch Nippersink Creek Tributary

near Genoa City, WI

\section{ST. CROIX RIVER BASIN}

\section{$05340300 \quad$ Trade River near Frederic, WI}

05341313 Bull Brook at CTH F near Amery, WI

05341900 Kinnickinnic River Tributary at River Falls, WI

05346294 Goose Creek at Beldenville, WI

05355315 Lost Creek near Waverly, Wi

\section{TREMPEALEAU-BLACK RIVER BASIN}

$\begin{array}{ll}05371800 & \text { Buffalo River Tributary near Osseo, WI } \\ 05371920 & \text { Buffalo River near Mondovi, WI } \\ 05379187 & \text { Pine Creek at Taylor Road near Taylor, WI } \\ 05379288 & \text { Bruce Valley near Pleasantville, WI } \\ 05380900 & \text { Poplar River near Owen, WI } \\ 05380970 & \text { Cawley Creek near Neillsville, WI } \\ 05381383 & \text { Glenn Creek near Millston, WI } \\ 05382200 & \text { French Creek near Ettrick, WI } \\ 05387100 & \text { North Fork Bad Axe River near Genoa, WI }\end{array}$

\section{UPPER WISCONSIN RIVER BASIN}

05391260 Gudegast Creek near Starks, WI

05391950

05392150

05392350

05393640

05394200
Squaw Creek near Harrison, WI

Mishonagon Creek near Woodruff, WI

Bearskin Creek near Harshaw, WI

Little Pine Creek near Irma, WI

Devil Creek near Merrill, WI 


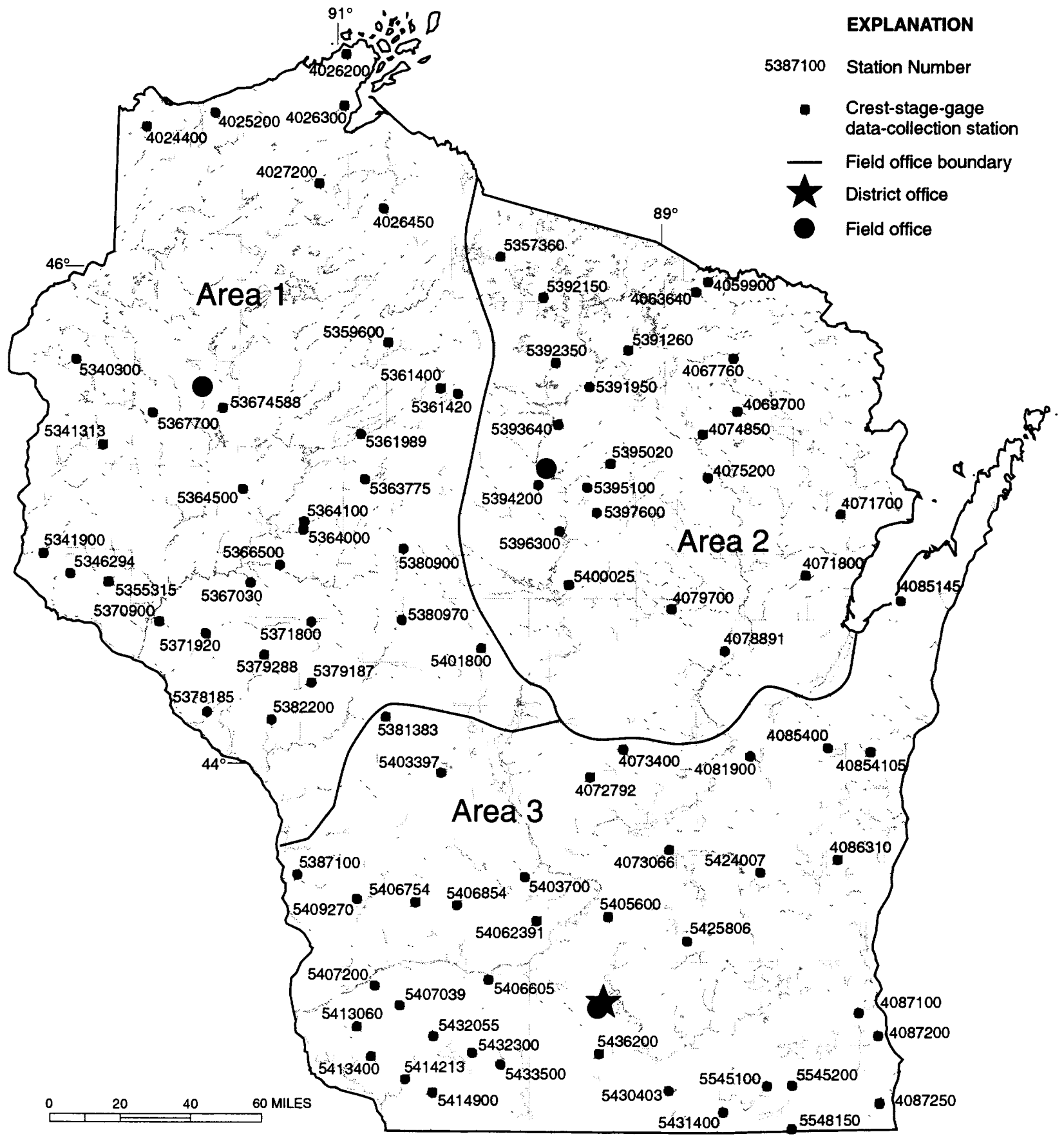

Figure 9. Location of crest-stage-gage data-collection stations. 


\section{MENOMINEE TRACE ELEMENT MONITORING, WI 12301}

COOPERATORS:

Menominee Indian Tribe of

Wisconsin

\section{LOCATION:}

Menominee Indian Reservation

PROJECT CHIEF:

Herbert S. Garn

Kevin D. Richards

PERIOD OF PROJECT:

March 1996 to September 2001

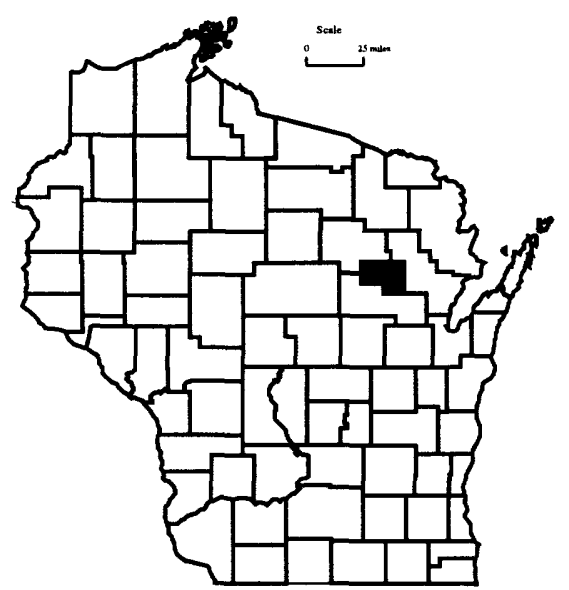

PROBLEM: Maintaining the quality and pristine nature of the Wolf River and its tributaries is extremely important to the Menominee Indian Tribe of Wisconsin (MITW) in the Upper Wolf River Basin. Information is needed to describe the current status of water quality and biotic conditions within the Reservation, and to determine the presence or absence of contaminants in major streams. Several years of data are available from a recently-completed study at a limited number of USGS sites (three) on the Wolf River near the Reservation boundaries for discharge, major ions and nutrients (1986-98), trace metals (1995-98), organics, and aquatic communities. Samplings were conducted for concentrations in water and for trace metals in water, fish livers, aquatic invertebrates, and streambed sediment. No similar comparative data exist for the major streams tributary to the Wolf River or other headwater streams originating and flowing out of the Reservation. A historical database for other streams within the Menominee Indian Reservation is needed to evaluate present conditions and provide a baseline from which changes in conditions may be determined.

OBJECTIVE: The primary objective of the monitoring is to establish data at a network of stations throughout the Reservation that will be useful for characterizing existing water-quality conditions, developing water-quality and watershed-management plans, and helping conserve and protect ambient conditions and ecosystems of the Reservation. Specific objectives are to (1) determine physical properties and concentrations of chemical constituents in water-column samples of all major streams on the Reservation and (2) quantify and characterize benthic invertebrate communities at the selected sample sites as an additional indicator of water-quality and environmental conditions.

APPROACH: Water sampling will be conducted to determine physical properties, major ion, and nutrient concentrations at two USGS sampling sites on the Wolf River plus 10 new sites on major tributaries to the Wolf River and other streams entering or leaving the reservation. Water-sampling frequency at each of the sites will be roughly quarterly beginning in October 2000 plus one synoptic sample during high-flow conditions, to yield five samples per site. Pesticide samples will be collected at three sites each sampling time. Sampling will be conducted using standard protocols of the USGS National Water Quality Assessment (NAWQA) program. Streamflow data will be collected at the USGS gaging station at Langlade.

Biological sampling for benthic macroinvertebrates will be done at all sites using a fixed-effort qualitative sampling of all available habitats ("multi-habitat") to provide a single composite sample. Biological sampling will be conducted once in the fall 2000 at low flow. All sampled analyses will be performed by the USGS National Water Quality Laboratory. 
PROGRESS (July 2000 to June 2001): Water and benthic macroinvertebrate sampling were completed for the remainder of the year. The gaging station at Langlade was operated and discharge data published in the report, "Water Resources Data-Wisconsin, Water Year 2000." A report team was organized to work on a waterresources investigations report to analyze and interpret the data collected over the course of the study.

PLANS (July 2001 to June 2002): Water-quality sampling will be completed in September 2001. The gaging station at Langlade will be operated and discharge data published in the report, "Water Resources Data-Wisconsin, Water Year 2001."

\section{REPORTS:}

Garn, H.S., Scudder, B.C., Richards, K.D., and Sullivan, D.J., Characteristics of water, sediment, and benthic communities of the Wolf River, Menominee Indian Reservation, Wisconsin, 1986-98: U.S. Geological Survey Water-Resources Investigations Report 01-4019, 54 p. 


\section{COMPILATION AND ANALYSIS OF WATER-RESOURCES DATA NEAR THE ST. CROIX RESERVATION, WISCONSIN, WI 12303}

COOPERATOR:

St. Croix Tribe of Wisconsin

LOCATION:

Barron, Burnett, and

Polk Counties, Wisconsin

PROJECT CHIEF:

David A. Saad

Dale M. Robertson

PERIOD OF PROJECT: January 1999 to September 2000
PROBLEM: The current and future health of several lakes, creeks, and rivers near the St. Croix Reservation, Wisconsin, is of concern to Tribal members. The Tribe is interested in documenting historical and current water quality, developing management plans for these water resources and protecting their lakes and watersheds.

OBJECTIVE: The objective is to provide the Tribe with a summary and analysis of available water-resources data near the St. Croix Reservation. This information will be used to aid in developing management plans for Big Round, Big Sand, Clam, Gaslyn, and Sand Lakes, Loon Creek, and the St. Croix and Yellow Rivers near the Reservation.

APPROACH: Water-resources information for the lakes, rivers and ground water in the study area will be compiled from available databases and through literature searches. Water-quality data will be obtained from databases maintained by the USGS, Wisconsin Department of Natural Resources, and U.S. Environmental Protection Agency. The compiled surface-water information will include physical, chemical, and biological characteristics of the lakes and streams and will be compared, where possible, to the land use and other environmental factors important to each watershed. This summary will provide a starting point for development of water-quality sampling strategies for the surface-water resources of interest to the Tribe.

PROGRESS (July 2000 to June 2001): The report, Waterresources-related information for the St. Croix Reservation and vicinity, Wisconsin, has been published and copies sent to the Tribe.

PLANS: Project is complete.

\section{REPORTS:}

Saad, D.A., and Robertson, D.M., Water-resources-related information for the St. Croix Reservation and vicinity, Wisconsin: U.S. Geological Survey Water-Resources Investigations Report 00$4133,65 \mathrm{p}$.

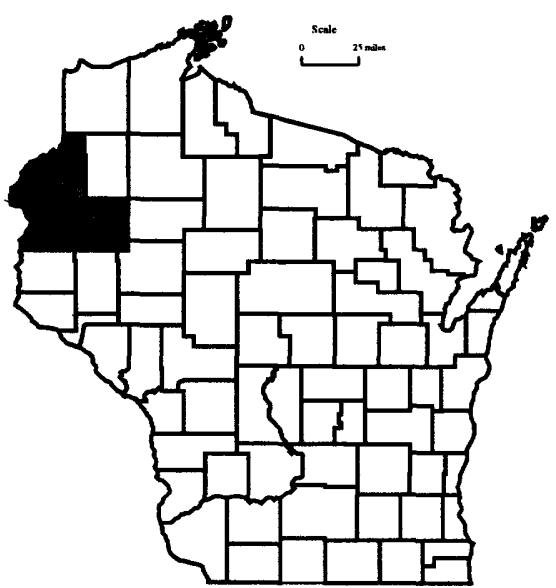


PROBLEM: The Oneida Nation in Wisconsin has developed a seven-generation plan for their reservation that includes instituting land-use practices that will allow the surface-water system draining the reservation the opportunity to revert to its pre-colonial condition. The Oneida Nation needs continuing information regarding waterquality conditions entering and within their Nation's boundaries. The information is needed to determine trends in water quality and provide data to assess the Tribe's water resources.

OBJECTIVE: The objective is to collect long-term data at two sites to perform trend analysis for pesticides, nutrients and suspended sediment.

APPROACH: Sampling will be conducted at two sites to determine concentrations of nutrients, pesticides, and suspended sediment. Field parameters will also be collected and sampling will take place on a fixed interval. The National Water Quality Lab will do the analysis of the water samples. National Water Quality Assessment protocols will be followed in the collection and handling of the water-column samples. A staff person from the Oneida Nation Environmental Section will work with a USGS staff person in the collection of data.

PROGRESS (July 2000 to June 2001): Samples were collected at two sites monthly. Samples were analyzed for pesticides, nutrients and suspended-sediment concentrations. Data collected in 2000 were published in the report, "Water Resources Data-Wisconsin". A water-resources investigations report was published in November 2000.

PLANS (July 2001 to June 2002): Data from samples collected from October 1, 2001 through September 30, 2002, will be published in the report, "Water Resources Data-Wisconsin". Waterquality sampling will be conducted at two sites and continue indefinitely.

\section{REPORTS:}

Schmidt, Morgan A., Richards, Kevin D. and Scudder, Barbara C., Surface-water quality, Oneida Reservation and vicinity, Wisconsin, 1997-98, U.S. Geological Survey Water-Resources Investigations Report 00-4179, $30 \mathrm{p}$.

\author{
COOPERATOR: \\ Oneida Nation of Wisconsin
}

\author{
LOCATION: \\ Oneida Indian Reservation
}

PROJECT CHIEF:
Kevin D. Richards

PERIOD OF PROJECT: August 1997 to September 2002

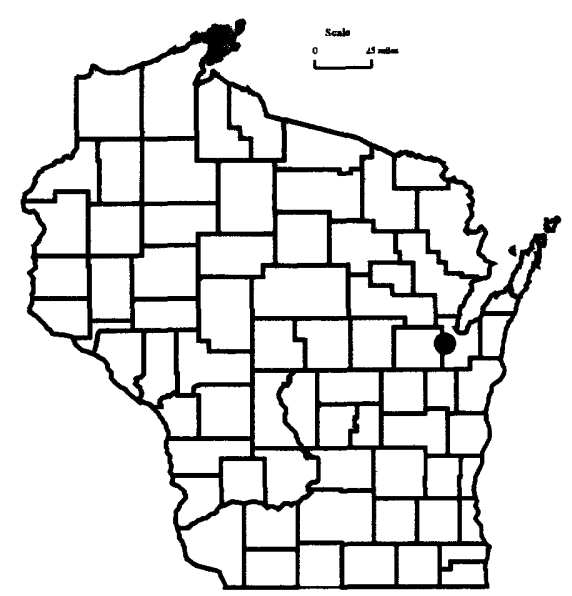




\section{DELINEATION OF THE AREA OF GROUND-WATER CONTRIBUTION AND THE TIMES OF TRAVEL TO COMMUNITY WATER SYSTEMS ON THE MENOMINEE INDIAN RESERVATION, WI 12312}

COOPERATOR:

Menominee Indian Tribe of Wisconsin

LOCATION:

Menominee County

PROJECT CHIEF:

Charles Dunning

PERIOD OF PROJECT: October 1998-Continuing

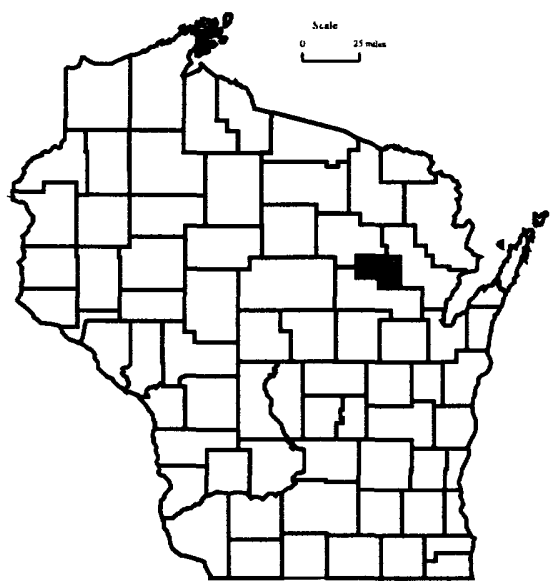

PROBLEM: The Menominee Indian Tribe is interested in determining the contributing areas and time of travel for water captured by wells for a number of community water systems in Menominee County, Wisconsin. The Tribe's interest in well-head protection is heightened over concern about the presence of elevated nitrate levels in several wells.

OBJECTIVE: The objective of the study is to determine the contributing areas and time of travel for water captured by community wells. This information will be used by the Menominee Indian Tribe for water resource and well-head protection planning in community areas.

APPROACH: The USGS will construct a simple one-layer ground-water model to simulate the hydrologic conditions in an appropriate area around community wells. The ground-water model will be used to delineate the zone of ground-water contribution to the wells for 5-, 10- and 100-year times of travel, and define the associated area of contribution. The results of these investigations will provide the Tribe with the necessary information to plan a well-head protection strategy for each community system.

PROGRESS (July 2000 to June 2001): Assistance was provided to the Menominee Indian Tribe in identifying locations for new Zoar community wells which will avoid the elevated nitrate found in the current wells. The reservation-wide analytic element model has been constructed and flux and head targets are being incorporated. Field activities around the town of Neopit are underway.

PLANS (July 2001 to June 2002): Ground-water-flow modeling will be completed at three other communities on the Reservation-Middle Village, Onekewat and Redwing. The hydrogeologic study around the town of Neopit focusing on the community wells and the sewage treatment lagoons will be completed. Results of these investigations will be presented in a USGS water-resources investigations report. 


\section{LAKE WATER-QUALITY MONITORING, CHEMICAL AND BIOLOGICAL MONITORING OF SELECTED LAKES, WI 13300}

\section{COOPERATORS:}

In the 2000 water year:

Benedict/Tombeau, Big Cedar, Buffalo, Eagle Spring, Little Cedar, Little Green, Lauderdale, Middle Genesee, Okauchee, Potter, Powers, and Wind Lake Districts; City of Muskego (Big Muskego and Little Muskego Lakes); townships of Casey (Big, Middle, and Lower McKenzie Lakes), Namekagon (Namekagon Lake), Sand Lake (Big Sissabagama), and Wascott (Whitefish Lake); and Village of Oconomowoc Lake (Oconomowoc Lake)

In the 2001 water year:

Big Cedar, Booth, Buffalo, Eagle Spring, Lac La Belle, Little Cedar, Little Green, Middle Genesee, Okauchee, Potter, Powers, and Wind Lake Districts; city of Muskego (Big Muskego and Little Muskego Lakes); St. Croix Indian Tribe (Big Round and Big Sand Lakes) townships of Sand Lake (Big Sissabagama), and Wascott (Whitefish Lake); and village of Oconomowoc Lake (Oconomowoc Lake)

PROBLEM: Lakes are a significant and valuable resource in the State of Wisconsin and are experiencing increased pressure from development and use. Many lakes do not have adequate water-quality information available for management of the lake. Hence, their water quality needs to be assessed and documented.

OBJECTIVE: Objectives of this project are to (1) determine the current water quality and trophic status of lakes, (2) assess the condition of specific lakes in comparison with other lakes of the same type in the region, and (3) build a quantitative database so that any detrimental changes or trends that might occur in the future can be detected quickly and evaluated objectively.

APPROACH: Water quality at each lake will be monitored in February, April, June, July, and August. Depth profiles of dissolvedoxygen concentration, temperature, $\mathrm{pH}$, and specific conductance will be determined. In April, the lakes will be sampled for analysis of the major anions and cations, nitrogen, and dissolved phosphorus. Secchi-depth measurements will be made for all months (except February), and total phosphorus and chlorophyll $a$ samples will be collected and analyzed. Lake stage will be measured at each of the five visits to the lake.
LOCATION:

Selected lakes in Wisconsin

PROJECT CHIEF:

William J. Rose

PERIOD OF PROJECT: June 1983-Continuing 


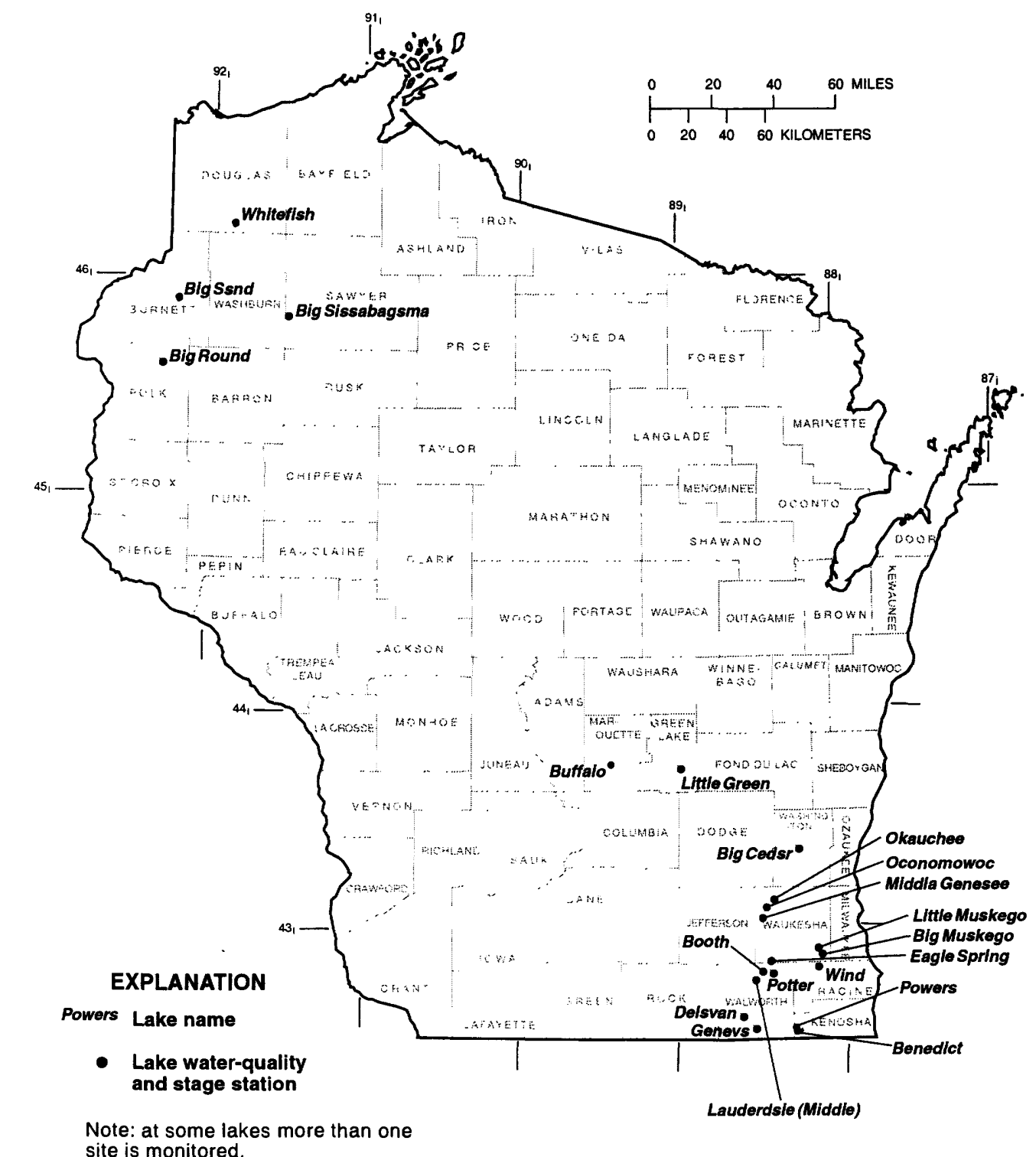

Note: at some lakes more than one site is monitored.

PROGRESS (July 2000 to June 2001): Total phosphorus, chlorophyll $a$, dissolved oxygen, temperature, $\mathrm{pH}$, specific conductance, and Secchi-depth data were collected and analyzed for 18 lakes during water year 2000 . In water year 2000 , Big Cedar was added to the program. The locations of lakes included in the monitoring program for water years 2000-2001 are shown on the following map.

PLANS (July 2001 to June 2002): Twenty lakes will be monitored in water year 2001. Data collected during the year will be compiled and transmitted to the respective cooperator. The data will be prepared for publication in the annual report "Water Quality and Lake-Stage Data for Wisconsin Lakes, water year 2001". 


\section{FOX RIVER REMEDIATION, WI 14500}

PROBLEM: Several Fox River bottom sediment deposits are being considered for remediation based upon high PCB concentrations. The pilot remediation project at deposit "N" (Kimberly) began in November 1998 and, in August 1999, pre-dredge sampling commenced at the Sediment Management Unit (SMU) 56_57 (Green Bay). There is a need, as part of the Fox River Remediation Assessment Team (FRRAT) efforts, to monitor and collect environmental data before, during, and after the remediation operation.

OBJECTIVE: Monitoring and sampling will be conducted to meet the project Quality Assurance Project Plan objectives. The objectives are to (1) evaluate baseline conditions prior to dredging activities, (2) evaluate short-term impacts, including PCB mass fluxes during dredge activities, and (3) evaluate conditions following the completion of dredge-related activities.

APPROACH: Deposit "N"-The baseline investigation consists of water column samples collected at four upstream locations and four downstream locations prior to the commencement of dredging. Bottom sediment samples will be collected from a minimum of 30 locations in Deposit $\mathrm{N}$ and an intermediate zone located between the sediment deposit and the silt-containment barrier.

Evaluation of short-term impact includes water-column sampling at four upstream and four downstream locations, dredge slurry samples and continuous-flow monitoring, composite samples of all on-shore processing locations, composite samples of processed solids for landfill disposal, samples of filter media, and treated carriage water samples.

Evaluation of long-term impacts will include collecting sediment core samples from the same locations as the pre-dredge sample sites and an intermediate zone characterization using visual reconnaissance and sampling.

SMU 56_57-The baseline investigation consists of water-column samples collected at four upstream locations and five downstream locations prior to the commencement of dredging.

Evaluation of short-term impact includes water-column sampling at four upstream and five downstream locations, dredge slurry samples with continuous-flow monitoring and composite samples of processed and treated carriage water samples.

PROGRESS (July 2000 to June 2001): Deposit “N"-Preand post-dredge cores have been collected and processed at 30 locations along with the intermediate zone. Over 90 PCB samples, 800 TSS samples, and over 6,400 water-quality measurements have been collected at the water-column sites. Shore-side (remediation process) samples and slurry flow data have been collected for 29 continuous days. The USGS mercury lab has completed the bottom sediment and remediation process sample analyses. The data analyses and draft report have been written evaluating the water-column transport and the shore-side processes.
COOPERATOR:

Wisconsin Department of

Natural Resources

\section{LOCATION: \\ Outagamie County \\ Brown County}

\section{PROJECT CHIEF:} Jeffrey Steuer

PERIOD OF PROJECT:

August 1998 to September 2001

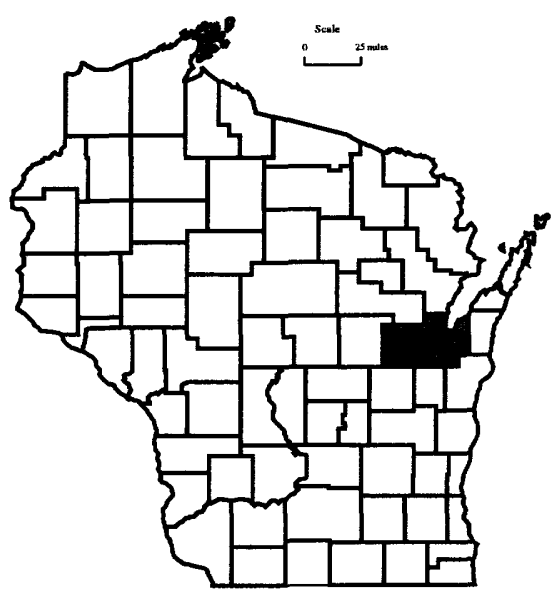


SMU 56_57-Over 90 PCB samples, 800 TSS samples, and over 6,400 water-quality measurements have been collected at the watercolumn sites. Assistance was provided in the slurry sampling and five 80-liter effluent samples were processed. Data analysis has commenced.

PLANS (July 2001 to June 2002): SMU 56_57 data analysis and report writing will be conducted in conjunction with the FRRAT.

\section{REPORTS:}

Fox River Remediation Advisory Team, 2000, Evaluation of the effectiveness of remediation dredging: the Fox River Deposit $\mathrm{N}$ Demonstration Project November 1998-January 1999: Water Resources Institute Special Report 00-01.

Steuer, J.J., 2000, A mass-balance approach for assessing PCB movement during remediation of a PCB-contaminated deposit on the Fox River, Wisconsin: U.S. Geological Survey WaterResources Investigations Report 00-4245, 8 p. 


\section{TECHNICAL AND FIELD SUPPORT FOR U.S. ENVIRONMENTAL PROTECTION AGENCY, REGION 5, WI 16400}

PROBLEM: The U.S. Environmental Protection Agency, Region 5, has requested that the Wisconsin District provide technical assistance with hydrogeological characterization of contaminated sites within the Region. These sites may be designated as Superfund or brownfields sites.

OBJECTIVE: The objectives are to provide the requested assistance and add to the understanding of the ground-water hydrology in the Region.

APPROACH: The Wisconsin District will provide hydrological, geophysical and field expertise to EPA activities in the Region. In addition, drilling, monitoring well installation, and aquifer testing will be conducted by Wisconsin District personnel in support of EPA activities.

PROGRESS (July 2000 to June 2001): Ground-water-flow modeling continues in support of the City of Milwaukee's Brownfield Demonstration Pilot Project in the Menomonee Valley.

PLANS (July 2001 to June 2002): Several reports are in preparation or review. Plans are for these to be completed this fiscal year. Additional assistance will be provided at sites in EPA Region 5 upon request.

\section{REPORTS:}

Brown, T.A. Dunning, C.P., and Sharpe, J.B., 2000, Structure, depth and thickness of the Galena-Platteville Bedrock Unit in the subcrop area of Illinois and Wisconsin, U.S. Geological Survey Water-Resources Investigations Report 97-4054-C, 3 plates.

Batten, W.G., Yeskis, D.J., and Dunning, C.P., 1999, Hydrogeologic properties of the Ordovician Sinnipee group at test well BN483, Better Brite Superfund site, DePere, Wisconsin, U.S. Geological Survey Water-Resources Investigations Report 994199, 19 p.

Brown, T.A., and Dunning, C.P., 1997, Structure, depth and thickness of the Galena-Platteville Bedrock Unit in the subcrop area of Illinois and Wisconsin, U.S. Geological Survey WaterResources Investigations Report 97-4054-C, 3 plates.

Batten, W.G., Brown, T.A., Mills, P.C., and Sabin, T.J., 1997, Rockstratigraphic nomenclature, lithology, and subcrop area of the Galena-Platteville Bedrock Unit in Illinois and Wisconsin, U.S. Geological Survey Water-Resources Investigations Report 974054-B.

Brown, T.A., Dunning, C.P., and Batten, W. G., 1997, Bibliography of selected references on the hydrogeologic and chemical properties of the Galena-Platteville Bedrock Unit in Illinois and Wisconsin, 1877-1997, U.S. Geological Survey WaterResources Investigations Report 97-4054-A, 44 p.
COOPERATOR:

U.S. Environmental Protection

Agency, Office of Superfund

LOCATION:

EPA-Region 5 (Wisconsin, Illinois, Michigan, Minnesota, Indiana and Ohio)

PROJECT CHIEF:

Charles Dunning

PERIOD OF PROJECT: November 1988-Continuing

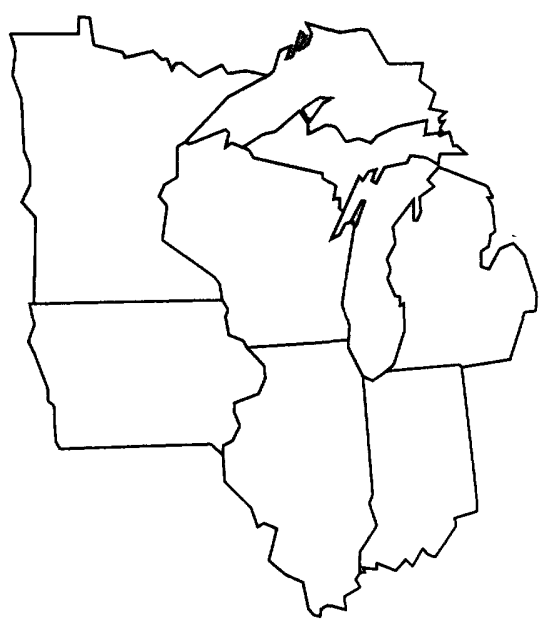




\section{EVALUATION MONITORING IN WISCONSIN PRIORITY WATERSHEDS, WI 17202-17204, 17213}

COOPERATOR:

Wisconsin Department of Natural Resources

\section{LOCATION:}

Priority watersheds in Brown, Buffalo, and Sheboygan Counties

PROJECT CHIEF:

David J. Graczyk

Steven R. Corsi

Judy A. Horwatich

PERIOD OF PROJECT: October 1990-Continuing

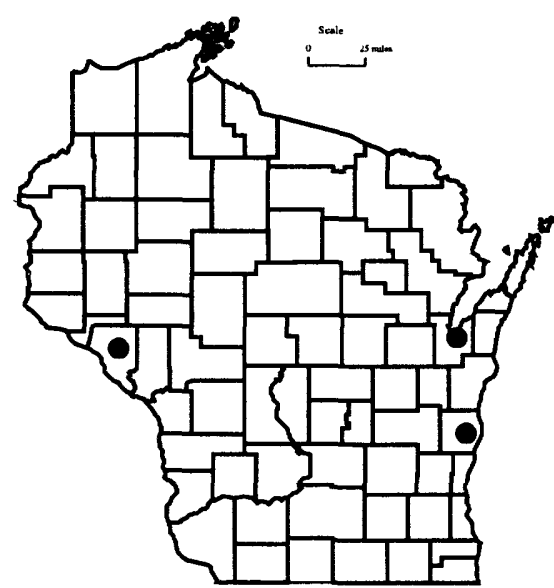

PROBLEM: An evaluation strategy is needed to assess the effectiveness of nonpoint-source pollution control measures in priority watersheds. Several important processes require research including the role of ground water in nonpoint-source contamination, factors leading to dissolved-oxygen reduction in a stream during runoff events, and the impact of management practices on bedload transport. Several techniques need to be developed and/or refined, such as detecting trends in stream-water chemistry, sampling of fish and fish habitat, relation between fish/fish habitat and changes resulting from watershed management practices, and use of habitat models for determining impact of watershed management on fish populations.

OBJECTIVE: The overall objective of this project is to determine the trends in water quality for three sites during and after implementation of improved land-management practices in three priority watersheds and to use GIS to understand changes in land use/land cover.

APPROACH: Post-practice implementation monitoring will be done for Otter, Eagle, and Joos Valley Creeks, which are in the Sheboygan and Waumandee Priority Watershed Projects, respectively. The pre-practice implementation is complete for the three sites. Continuous-record streamflow, water temperature, and dissolvedoxygen gaging stations were installed at each stream site. Waterquality samples will be collected during events and low flows and analyzed for selected constituents. Land-use inventories will be taken each year to help determine the cause of any changes in water quality.

PROGRESS (July 2000 to June 2001): Post-practice implementation monitoring was begun for Otter Creek. Water-quality loads were calculated for selected parameters and storm periods. All the data were summarized and published in the report "WaterResources Data-Wisconsin". Land-use inventories were completed for each basin.

PLANS (July 2001 to June 2002): Streamflow and waterquality monitoring will be continued at Otter Creek site. Eagle and Joos Valley Creeks will be monitored for streamflow and water quality beginning in May 2002. Water-quality loads for selected parameters and storm periods will be calculated and compared to data collected in previous years. The data will be analyzed to determine if there are any apparent trends in water quality during implementation of best management plans. At Otter Creek, water-quality samples will be collected weekly during the period of April-October, biweekly in March and November, and monthly during December, January, and February. Land use will be updated for each basin. A report will be published on post monitoring of Brewery and Garfoot Creeks in the Black Earth Creek Priority Watershed Project. 


\section{REPORTS:}

Wierl, J.A., Giddings, E.M., and Bannerman, R.T., 1998, Evaluation of a method for comparing phosphorus loads from barnyards and croplands in Otter Creek Watershed, Wisconsin, U.S. Geological Survey Fact Sheet 168-98, 4 p.

Corsi, S.R., Graczyk, D.J., Owens, D.W., and Bannerman, R.T., 1997, Unit-area loads of suspended sediment, suspended solids, and total phosphorus from small watersheds in Wisconsin: U.S. Geological Survey Fact Sheet 195-97, 4 p.

Rappold, K.F., Wierl, J.A., and Amerson, F.U., 1997, Watershed characteristics and land management in the nonpoint-source evaluation monitoring watersheds in Wisconsin: U.S. Geological Survey Open-File Report 97-119, 39 p.

Wierl, J.A., Rappold, K.F., and Amerson, F.U., 1996, Summary of the land-use inventory for the nonpoint-source evaluation monitoring watershed in Wisconsin: U.S. Geological Survey OpenFile Report 96-123, 23 p.

Greb, Steven R., and Graczyk, David J., 1995, Frequency-duration analysis of dissolved-oxygen concentrations in two southwestern Wisconsin streams, Water Resources Bulletin v. 31, no. 3, p. 431-438. 
COOPERATOR:

Wisconsin Department of

Natural Resources

\section{LOCATION:}

State of Wisconsin

\section{PROJECT CHIEF: John F. Walker}

PERIOD OF PROJECT: October 1989 to September 2001
PROBLEM: To date, the effectiveness of best management practices (BMPs) in Wisconsin has not been determined. The natural variability of water-quality data complicates the detection of changes due to BMP implementation. Research is needed to identify techniques for detecting changes due to BMP implementation and applying the techniques to before and after data.

OBJECTIVE: The objective is to investigate statistical analysis techniques for assessing trends in water quality due to BMP implementation using data from other states. The effectiveness of BMPs in two urban basins and seven rural basins in Wisconsin will be determined using the identified statistical techniques.

APPROACH: A comprehensive literature search will be conducted to identify viable statistical analysis techniques and needs for method modification or development. Data for several rural and urban basins in other states will be compiled and used to test the selected techniques. Storm loads of total-suspended solids and total phosphorus will be computed and used along with rainfall data and land-use information to assess the effectiveness of the BMPs in several basins in Wisconsin.

PROGRESS (July 2000 to June 2001): The annual progress report describing results and data analysis for data through the 1998 Water Year was completed and approved. A draft of the report summarizing the final results for Black Earth Creek was completed and submitted for review.

PLANS (July 2001 to June 2002): The annual progress report and the final Black Earth Creek report will be published and distributed. A journal article describing the Black Earth Creek results will by completed and submitted to an appropriate journal for review.

\section{REPORTS:}

Walker, J.F., Graczyk, D.J., Corsi, S.R., and Horwatich, J.A., 2001, Evaluation of nonpoint source contamination, Wisconsin: selected data for water year 1998, U.S. Geological Survey OpenFile Report, in press.

Walker, J.F., Graczyk, D.J., Horwatich, J.A., and Bannerman, R., 2001, Evaluation of best-management practices in the Black Earth Creek, Wisconsin watershed, U.S. Geological Survey Water-Resources Investigations Report, in press.

Owens, D.W., Corsi, S.R., and Rappold, K.F., 1997, Evaluation of nonpoint-source contamination, Wisconsin: selected data for water year 1995, U.S. Geological Survey Open-File Report 96$661 \mathrm{~A}$. 
Walker, J.F., Graczyk, D.J., Corsi, S.R., Owens, D.W., and Wierl, J.A., 1995, Evaluation of nonpoint-source contamination, Wisconsin: land use and best management practices inventory, selected streamwater-quality data, urban-watershed quality assurance and quality control, constituent loads in rural streams, and snowmelt-runoff analysis, water year 1994: U.S. Geological Survey Open-File Report 95-320, 21 p.

Corsi, S.R., Walker, J.F., Graczyk, D.J., Greb, S.R., Owens, D.W., and Rappold, K.F., 1995, Evaluation of nonpoint-source contamination, Wisconsin: selected streamwater-quality data, landuse and best-management practices inventory, and quality assurance and quality control, water year 1993: U.S. Geological Survey Open-File Report 94-707, 57 p.

Walker, J.F., 1994, Statistical techniques for assessing water-quality effects of BMPs, ASCE J. of Irrigation and Drainage Engineering, v. 120 , no. 2 , p. 334-347.

Walker, J.F., and Graczyk, D.J., 1993, Preliminary evaluation of effects of best management practices in the Black Earth Creek, Wisconsin, priority watershed: Water Science and Technology, v. 28 , no. $3-5$, p. $539-548$.

Walker, J.F., 1993, Techniques for detecting effects of urban and rural land-use practices on stream-water chemistry in selected watersheds in Texas, Minnesota, and Illinois: U.S. Geological Survey Open-File Report 93-130, 16 p.

Graczyk, D.J., Walker, J.F., Greb, S.R., Corsi, S.R., Owens, D.W., 1993, Evaluation of nonpoint-source contamination, Wisconsin: Selected data for 1992 water year: U.S. Geological Survey Open-File Report 93-630, 48 p. 


\section{VERIFICATION OF TREATMENT PERFORMANCE OF THE VORTECHNICS AND STORMWATER MANAGEMENT FILTER, WI 17207}

\author{
COOPERATOR: \\ Wisconsin Department of \\ Transportation
}

LOCATION:

City of Milwaukee

PROJECT CHIEF:

Judy Horwatich

Dave Owens

PERIOD OF PROJECT:

October 2000 to September 2002
PROBLEM: The Wisconsin Department of Transportation (WDOT) is required to improve the quality of runoff from roadways under their control as part of the National Pollution Discharge Elimination System (NPDES) and an agreement with the Wisconsin Department of Natural Resources (WDNR). In addition, future state and federal regulations will prescribe new performance standards for nonpoint runoff management and calculation requirements for total maximum daily loads (TMDLs) of contaminants discharging in watershed basins.

OBJECTIVES: The objectives of this project are to (1) determine the effectiveness of a Vortechnics Stormwater Treatment System and a Stormwater Management StormFilter System in removing pollutants from highway runoff water; (2) compare the measured removal efficiencies with manufacturers' estimates; (3) characterize the variability in freeway runoff quality; (4) calibrate SLAMM for freeways; and (5) determine the practical application of the treatment devices (e.g., installation, operation and maintenance costs).

APPROACH: Discharge and event mean concentration (EMC) data will be collected at the BMP inlets and outlets for 15 consecutive large (more than 0.15 inches of precipitation) runoff events. These samples will be analyzed for total phosphorus, suspended and dissolved solids, zinc, copper and chloride. Other samples from small (less than 0.15 inches of precipitation) events occurring between the larger events will be analyzed only for suspended solids. The data will be used to calculate individual event water-quality loads entering and exiting the BMPs. The calculated loads will be used to determine the removal efficiencies of the two treament systems for the test period and to determine if there are any efficiency patterns related to event size.

PROGRESS (October 2000 to June 2001): The project proposal has been completed and monitoring equipment has been ordered.

PLANS (July 2001 to June 2002): Monitoring equipment will be installed as soon as the treatment devices are delivered and connected into the overhead drainage system. It is expected that sampling will be initiated in August/September 2001 and should be concluded by October 2001 . This schedule depends on timely delivery and setup of the treatment devices. 


\section{VERIFICATION OF A PRESSURIZED STORMWATER FILTRATION SYSTEM AT ST. MARY'S HOSPITAL, WI 17208}

PROBLEM: Urban stormwater is degrading Wisconsin waters. Cost-effective treatment technologies are needed to reduce adverse impacts that urban stormwater runoff can have on surface-water quality. A variety of advanced technologies have emerged in recent years that can help communities achieve compliance with new regulations. The EPA's Environmental Technology Verification (ETV) Program established a cooperative agreement with the National Standards Foundation (NSF) International to verify the treatment capabilities of the proprietory treatment devices.

The Wisconsin Department of Natural Resources and the USGS will conduct a study of a pressurized stormwater filtration system as an ETV program. The system has been installed at St. Mary's Hospital in Green Bay and is being used to treat runoff from its parking lot and rooftops. Stormwater is captured and pumped through a twophase filter system and discharged into a city storm sewer. Backflush water is discharged into a sanitary sewer.

OBJECTIVE: The project objective is to determine the efficiency of the pressurized filtration system in extracting sediment, nutrients, and zinc from stormwater runoff.

APPROACH: To accomplish the above objective the following approach will be used: (1) install flow-monitoring and water-quality sampling equipment at the inflow, outflow and bypass of the system; (2) continuously monitor rainfall and flow and collect water-quality samples for 15 runoff events in 2001; (3analyze samples for sediment, total and dissolved phosphorus, Kjeldahl $\mathrm{N}, \mathrm{NO}_{2}-\mathrm{NO}_{3} \mathrm{~N}$, and zinc; (4) compute loads for inflow, filtered outflow, and bypass for the above constituents; (5) compute a mass balance on flow and water-quality loads for all events; and (6) publish a technical report on the results of the study.

PROGRESS (September 2000 to June 2001): All equipment has been installed and is operational. Several test samples have been collected.

PLANS (July 2001 to June 2002): Plans are to (1) monitor 15 consecutive storms that have more than 0.2 inches of rain, (2) compute the discharge record and water-quality loads for the three monitoring locations, (3) complete a mass balance summary for the monitored storms, and (4) publish the results of the study.
COOPERATOR:

Wisconsin Department of

Natural Resources

\section{LOCATION:}

Green Bay

PROJECT CHIEF: Judy Horwatich

Steve Corsi

PERIOD OF PROJECT: September 2000-Continuing

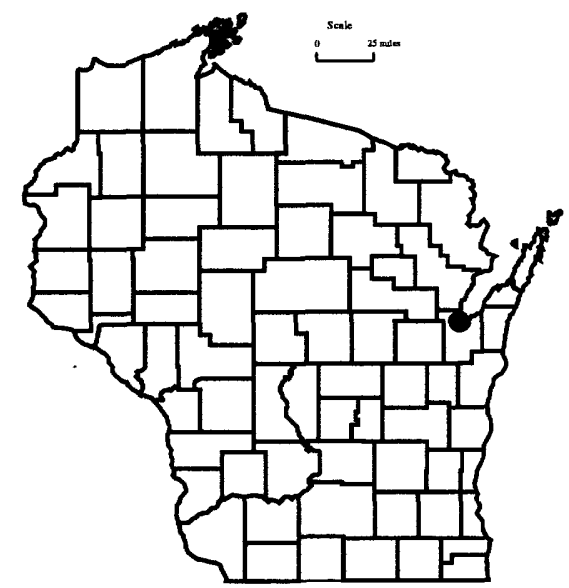




\section{HYDROLOGIC INVESTIGATION OF THE TOKEN CREEK WATERSHED, WI 17209}

\author{
COOPERATOR: \\ Wisconsin Department of \\ Natural Resources \\ Dane County Land Conservation \\ Department
}

\section{LOCATION: \\ Dane County}

\section{PROJECT CHIEF: \\ David Graczyk}

\section{PERIOD OF PROJECT: \\ May 2000 to October 2001}

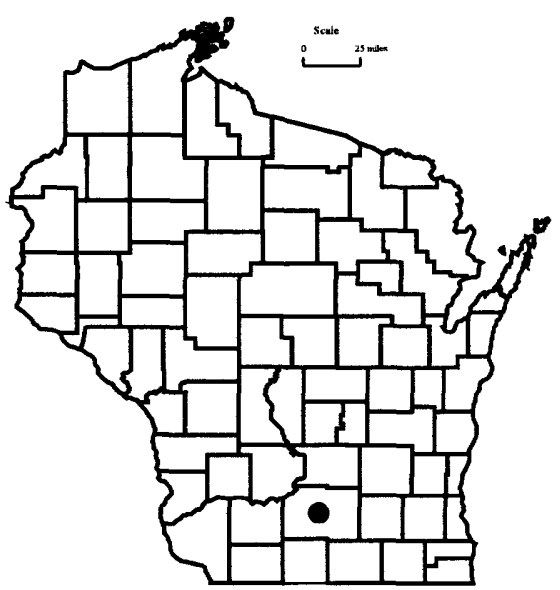

PROBLEM: In February 1994, the Token Creek millpond was partially opened exposing extensive springs and ground-water seeps in and along the periphery of the former pond. On July 16, 1996, a series of discharge and water temperatures measurements, extending from just downstream of Interstate 94 to upstream of the former pond limits, indicated that a significant portion of Token Creek streamflow is ground-water discharge. The temperature data indicated that sections of Token Creek could support brown trout. However, the specific extent of Token Creek which will support available, reproducing trout population is not known. The effect on water temperature of restoring the channel to a more 'natural' condition is unknown.

Increased ground-water withdrawals or urbanization in the vicinity of Token Creek may decrease ground-water discharge and/or increase the temperature of surface-water runoff to Token Creek. The Dane County Land Conservation Department will calibrate and verify a whole watershed model to determine the effects of urbanization and ground-water withdrawals on stream-water temperatures. The USGS will collect streamflow data at six sites and water temperature data at 12 sites that will be used for model inputs, calibration and verification.

OBJECTIVE: The overall objective of this study was to collect streamflow data at six sites and collect water temperature data at 12 sites in the Token Creek watershed.

APPROACH: Continuous recording streamflow monitoring sites were installed at six sites. These sites include a site just above the dam crest of the old millpond dam and a site just above the confluence of Token Creek with the Yahara River. Four additional sites were installed on the major tributaries to Token Creek. These include three watersheds that are highly urbanized and one watershed that is agricultural. Water temperature monitors were installed over the entire basin to determine the effects of different land uses on water temperature. Six raingages were installed in the Token Creek watershed.

PROGRESS (July 2000 to June 2001): All data collection equipment was installed in the Token Creek watershed. Numerous discharge measurements were made to determine stage-discharge relations at each of the streamflow monitoring sites. All data was collected and stored in the USGS NWIS database. The data was compiled and transmitted to the Dane County Land Conservation Department to be used as input to a whole watershed model. The data was also transmitted to the Wisconsin Department of Natural Resources. Data collection was completed September 30, 2000, and all data-collection monitors were removed.

PLANS: Project is complete. 


\section{SINGLE SOURCE SITES, WI 17214}

PROBLEM: Much work has been done to assess the effectiveness of nonpoint-source pollution-control strategies known as best management practices (BMPs). Most of this work to date has had a basin-wide scope and is focused on evaluating the cumulative effectiveness of several different types of BMPs. Research targeted at evaluating the effectiveness of a single type of BMP would assist resource managers responsible for planning BMP implementation programs.

OBJECTIVE: The objective is to determine the significance of a single nonpoint-pollution source and evaluate the effectiveness of BMPs in treating that same source.

APPROACH: Water-quality samples will be collected upstream and downstream from a single nonpoint-pollution source before and after implementation of BMPs. Water-quality samples are generally collected biweekly during open-water periods, and monthly during the winter months. In addition, water-quality samples are collected with automated water samplers during selected periods of storm runoff. Water-surface levels are continuously monitored at the sites, and a continuous discharge record is determined from water-surface/discharge relations.

Two barnyard-runoff sites have been fully investigated-Otter Creek in the Sheboygan River Priority Watershed and Halfway Prairie Creek in the Black Earth Creek Priority Watershed. The study concluded that implementation of barnyard BMPs at each site has significantly reduced the loadings of most constituents coming from the barnyards. Currently one streambank stabilization/barnyard-runoff site is being investigated-Parsons Creek in the Lake Winnebago Priority Watershed. Near stream vegetation buffers will be evaluated at an additional site in Buffalo County in the near future.

PROGRESS (July 2000 to June 2001): Post-streambank stabilization sampling was completed at Parsons Creek, with samples collected for eight storm-runoff periods. In addition, samples were collected for three snowmelt periods. Water discharge, water temperature, rainfall records and water-quality loads were analyzed for water year 2000 for the upstream, middle, and downstream sites and the data will be published in the 2001 data report. The stations will be discontinued in May 2000 until the barnyard BMPs are implemented.

Samples were collected for seven storm-runoff periods at Hutchinson Creek. Baseflow samples were collected according to schedule and measurements of streamflow were made when appropriate. Due to unforeseen circumstances, this site was discontinued in July 2000.
COOPERATOR:

Wisconsin Department of

Natural Resources

\section{LOCATION: \\ State of Wisconsin}

\section{PROJECT CHIEF: \\ Todd D. Stuntebeck}

\section{PERIOD OF PROJECT: March 1994-Continuing}

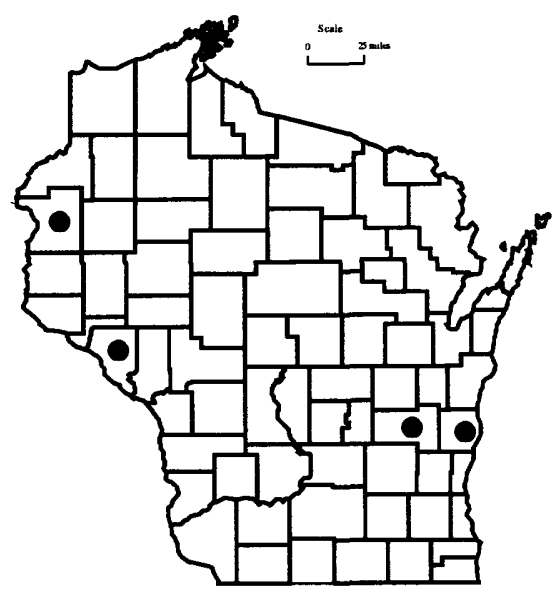


PLANS (July 2001 to June 2002): Equipment designed to collect water samples and to monitor streamflow will be installed at two sites on a small creek in Buffalo County. Water samples will be collected during storm-runoff events and at baseflow conditions. Periodic measurements of streamflow will be conducted to develop a stage-discharge relation for each site.

\section{REPORTS:}

Stuntebeck, T.D., and Bannerman, R.T., 1998, Effectiveness of barnyard best management practices in Wisconsin: U.S. Geological Survey Fact Sheet 051-98, 4 p.

Stuntebeck, T.D., 1995, Evaluating barnyard best management practices in Wisconsin using upstream-downstream monitoring: U.S. Geological Survey Fact Sheet 221-95, 4 p. 


\section{IMPACT OF PHOSPHORUS AND NITROGEN CONCENTRATIONS ON THE BIOLOGICAL INTEGRITY OF WISCONSIN STREAMS, WI 17223}

PROBLEM: Excessive phosphorus and nitrogen (nutrient) loss is frequently associated with water-quality problems in Wisconsin's water bodies. The implementation of the WDNR's proposed agricultural performance standards and prohibitions should decrease the risk of excessive nutrient loss from croplands and livestock operations. Landowners would be asked to limit their amount of commercial fertilizer use and reduce the impacts of manure storage and spreading. Implementation of TMDLs and the enforcement of phosphorus criteria would also reduce the problems caused by nutrients. The expected water-quality improvements due to the application of agricultural performance standards will vary due to differences in nutrient responses in each water body. In order to evaluate the environmental benefits of the proposed performance standards and phosphorus criteria, sufficient data would need to be collected on each stream to define the nutrient response. Nutrient data for some TMDLs should be collected and interpreted.

OBJECTIVE: Objectives of the project are to (1) determine what phosphorus and nitrogen concentrations impair the biological integrity of a stream; (2) develop a database that can be used to refine the phosphorus criteria for Wisconsin streams; (3) determine how watershed characteristics affect the relations between phosphorus and nitrogen concentrations in streams and the biological integrity of the streams; and (4) improve our biological assessment of nutrient impairments by developing a nutrient index of biological integrity.

APPROACH: The approach for the project is to statistically determine if any significant relations exist between a stream's phosphorus and nitrogen A statistical evaluation of the significant relations between nutrient concentrations and watershed characteristics will be completed. A multivariate statistical analysis will be used to sort out the importance of the many different variables. Since these nutrient relations are expected to vary with stream size and location of the stream in the state, streams will be grouped by size, two nutrient ecoregions and four nutrient zones. Streams will be divided into those with smaller watersheds of 4 to 50 square miles, those with medium watershed sizes of 50 to 200 square miles, and those with large watersheds of 200 to 1,000 square miles.

The variables in these statistical analysis will be based on five indicators of biological integrity, eight types of nutrient concentrations, and eight watershed characteristics. The five biological indicators are fish abundance and diversity, habitat quality, macroinvertebrate diversity, periphyton biomass, and suspended and attached chlorophyll $a$ concentrations. Water samples collected from the stream will be analyzed for total phosphorus, dissolved phosphorus, nitrate, total Kjeldahl nitrogen, ammonia, turbidity, conductivity, and suspended chlorophyll $a$. Watershed characteristics to be compiled from existing databases include drainage-area size, stream gradient, climate data, land use, annual runoff, surficial deposits data, soil types, soil erodability and riparian buffer data.
COOPERATOR:

Wisconsin Department of

Natural Resources

\section{LOCATION:}

Statewide

PROJECT CHIEF:

David J. Graczyk

Dale M. Robertson

PERIOD OF PROJECT:

March 2001 to June 2004

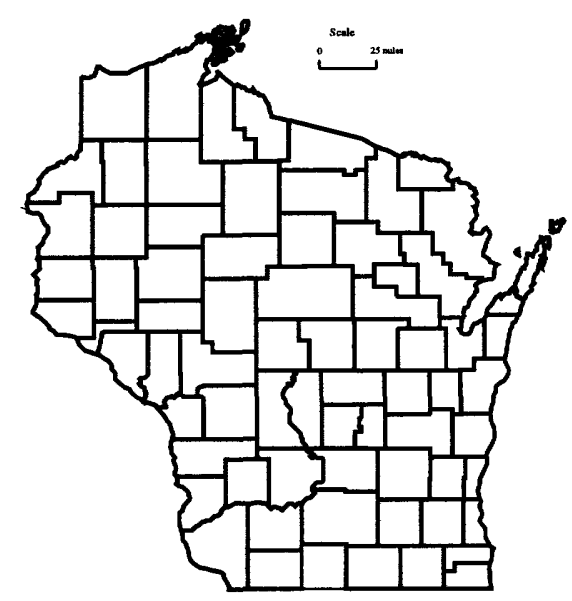


Small streams will be monitored in the first year. Based on the effort needed to collect water and periphyton samples and summarize the watershed characteristics, 160 small streams will be selected. There will be about 40 small streams in each nutrient zone or about 80 in each nutrient ecoregion. Many of the small streams will be selected from the streams sampled over the last five years. This fish and habitat data has been collected the same way at all the sites and the data is stored in a readily accessible database.

A total of six water-quality samples will be collected between the months of May and October for each of the 160 sites. The average concentrations of these six samples will be used in the statistical analysis.

Nutrient concentrations will be determined from samples collected at each stream by standard sampling methods. Samples will be iced and delivered to the State Laboratory of Hygiene for analysis. A flow measurement will be collected at the time of the water-quality grab sample.

PROGRESS (March 2001 to June 2001): Field sampling protocols were developed and monitoring equipment purchased. Water-quality samples and discharge measurements were completed for all 160 sites during May and June. Data has been entered into the data base.

PLANS (July 2001 to June 2002): Samples will be collected for the months of July through October. All data will be summarized and an annual data report will be prepared. The medium size streams (50 to 200 square miles) will be selected for data collection. Data collection for these streams will begin in May 2002. 


\section{HYDROLOGY AND WATER-QUALITY IMPACTS OF DIFFERENT PASTURE MANAGEMENT PRACTICES IN SOUTHWESTERN WISCONSIN, WI 17229}

PROBLEM: Nonpoint-source pollution is a major concern in Wisconsin. There are approximately 24,000 dairy farms in Wisconsin which may be sources of sediment, nutrients and pesticides to surface and ground water. Managed Intensive Rotational Grazing (MIRG) is a system that uses pastures as a major source of feed for milking cows (Jackson-Smith and others, 1996). MIRG farmers rely on pastures for their dairy herds' forage needs and move their cows to a new pasture at least once a week (Jackson-Smith and others, 1996). In 1992, roughly 7 percent of Wisconsin dairy farms used MIRG but, in 1994, 14 percent of Wisconsin dairy farms used MIRG (Jackson-Smith and others, 1996). MIRG can be used as a best management practice (BMP) and may reduce the amount of sediments, nutrients and pesticides to receiving waters. In a study in Oklahoma, rotational grazed pastures evidenced a reduction in average annual runoff and sediment discharges when compared to a continuously grazed basin (Menzel and others, 1978).

This study will compare surface-water runoff and water quality from three small pastured watersheds. The pastures will be located at the USDA Dairy Forage Research Center at Prairie du Sac.

OBJECTIVE: The overall objective of this study is to determine differences in quantity and quality of surface-water runoff from three different pasture-management strategies. These strategies consist of a variety of practices which are available to pasture managers, both during the growing and dormant seasons. Combinations of management practices have been chosen to represent commonly used strategies. In addition to examining differences in overall management strategies, differences related to individual seasonal practices will be determined. A secondary objective will be to determine a water budget for each pasture. The water budget will be determined by measuring surface-water runoff and precipitation. Evaporation and transpiration will be estimated by using empirical equations and ground-water flow will be estimated as a residual.

APPROACH: The management practices to be examined include (1) intensive rotational grazing and continuous grazing during the growing season; (2) pasture "stockpiling" during late summer and continued grazing throughout the summer; and (3) two outwintering practices and no outwintering. An artificial hydraulic control was installed at each pasture outlet. The control is a three-inch Parshall flume. Each site will use a pressure transducer to measure stage and a CR-10 data recorder. Daily, monthly and annual surface-water runoff will be calculated at each pasture. A tipping-bucket rain gage was installed at each site. Evapotranspiration will be estimated using empirical equations. Air temperature and solar radiation will be collected at one of the pastures for use in the evapotranspiration calculation. Meteorological data collected at the USDA Research Station will supplement data collected at this pasture. Ground-water flow will be calculated as a residual. An ISCO automatic water-quality sampler was installed at each site. The sampler will collect discrete samples. These samples will be composited on a flow-weighted
COOPERATOR:

Wisconsin Department of

Natural Resources

\section{LOCATION}

Sauk County

PROJECT CHIEF:

David J. Graczyk

PERIOD OF PROJECT:

October 1997 to September 2001

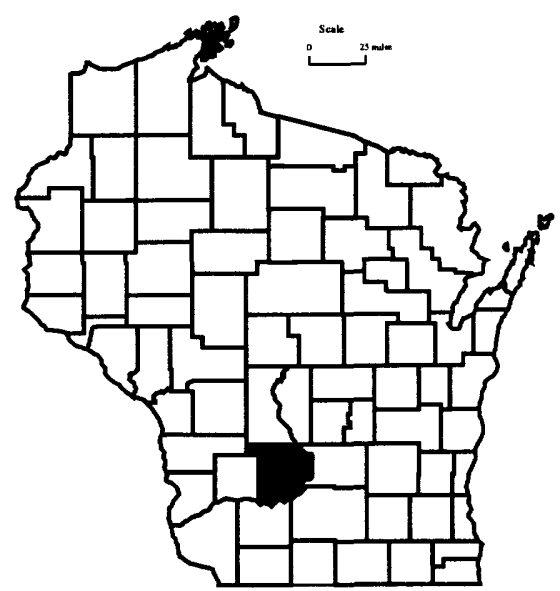


basis. One composite sample per rainfall or snowmelt event will be sent to the Wisconsin State Laboratory of Hygiene for analysis. All events will be monitored. Approximately 5-10 samples per pasture will be collected. All samples will be analyzed for soluble reactive phosphorus, total phosphorus, ammonia nitrogen, nitrate and nitrite nitrogen, total Kjeldahl nitrogen, total suspended solids, and volatile suspended solids.

PROGRESS (July 2000 to June 2001): Three small basins were monitored for continuous stream flow and rainfall. Four runoff samples were collected at two sites and three runoff samples were collected at the other site. Animal grazing was started in October of 2000 at the three sites according to the MIRG plan for each site. At two of the basins, the animals were outwintered in the basins. At the third basin, no outwintering of the animals was allowed. Total phosphorus concentration ranged from $0.35 \mathrm{mg} / 1$ to $16.3 \mathrm{mg} / \mathrm{l}$ at the three sites. The median total phosphorus concentration at the three sites for all samples collected ranged from $0.52 \mathrm{mg} / \mathrm{l}$ to $1.32 \mathrm{mg} / \mathrm{l}$. The storm loads for an intense summer thunderstorm (May 31 to June 1a total of 5.98 inches of rain) for total phosphorus ranged from 0.05 $\mathrm{lb}$ to $1.50 \mathrm{lb}$. The yields for this storm were $16.7 \mathrm{lb} / \mathrm{mi}^{2}, 114 \mathrm{lb} / \mathrm{mi}^{2}$, and $375 \mathrm{lb} / \mathrm{mi}^{2}$ of total phosphorus. The median total phosphorus yields for all samples collected ranged from $3.3 \mathrm{lb} / \mathrm{mi}^{2}$ to $9.2 \mathrm{lb} / \mathrm{mi}^{2}$. The suspended solids concentrations for this storm ranged from $355 \mathrm{mg} / \mathrm{l}$ to $7,020 \mathrm{mg} / \mathrm{l}$, with the loads ranging from $1.1 \mathrm{lb}$ to $446 \mathrm{lb}$. The yields of suspended solids at the sites were $3,533 \mathrm{lb} / \mathrm{mi}^{2}$, $64,778 \mathrm{lb} / \mathrm{mi}^{2}$, and $206,000 \mathrm{lb} / \mathrm{mi}^{2}$. The median suspended solids yields for all storms were $150 \mathrm{lb} / \mathrm{mi}^{2}, 960 \mathrm{lb} / \mathrm{mi}^{2}$ and $2,708 \mathrm{lb} / \mathrm{mi}^{2}$ at the three sites. Samples of the runoff were a result of both snowmelt and intense thunderstorms. All data were published in the report "Water Resources Data-Wisconsin, 2000".

PLANS (July 2001 to June 2002): Monitoring at all three sites will be continued. Water-quality samples will be collected at the three sites for all storms that produce runoff and water-quality loads will be calculated for each storm. Animal grazing will be continued according to the MIRG plan for each site. All streamflow and water-quality data will be summarized and published in the annual report "Water Resources Data-Wisconsin, 2001". 


\section{BRIDGE SCOUR ON BALSAM ROAD BRIDGE, WI 17230}

PROBLEM: Bridge scour has become a topic of nationwide interest in recent years but has not been identified as a serious problem for many bridges in Wisconsin. The Balsam Road bridge over the Big Eau Pleine River in Marathon County is one bridge, however, which has already been severely scoured with pier footings and pilings exposed. The scour hole is concentrated around the bridge location, beginning at approximately 200 feet upstream to approximately 200 feet downstream. An engineering assessment indicates that the 100-year return period discharge could undermine the east abutment and piers 1 and 2 and scour close to pile tip elevations on Pier 3 and the west abutment.

OBJECTIVE: The objective of this study is to install acoustic transducers to continuously monitor the scour depth on the upstream and downstream sides of the piers at the east side of the bridge. Discharge data from the streamflow gage at Stratford will be used to provide a high flow alert to the USGS and the Marathon County Highway offices to allow closure of the bridge if scour depths increase to dangerous levels.

APPROACH: Acoustic transducers will be attached to the upstream and downstream faces of the most eastern pier on the Balsam Road bridge. The scour depth data will be recorded on a datalogger and telemetered to the USGS office in Middleton, Wisconsin. This information will be automatically uploaded to the World Wide Web home page for the USGS Wisconsin District (http://wi.water.usgs.gov). A voice modem will be installed at the Big Eau Pleine River streamflow gage at Stratford and will be programmed to provide an alert to the Marathon County Highway Department and USGS offices that a flood event is occurring. This alert will provide the opportunity to closely monitor the scour depths to determine whether the bridge should be closed due to hazardous conditions.

PROGRESS (July 2000 to June 2001): Scour depth was monitored. Data has been made available on the World Wide Web.

PLANS (July 2001 to June 2002): Monitoring will continue through June 2002.
COOPERATOR:

Marathon County Highway

Department

LOCATION:

Marathon County

PROJECT CHIEF:

Peter E. Hughes

PERIOD OF PROJECT:

May 1998-Continuing

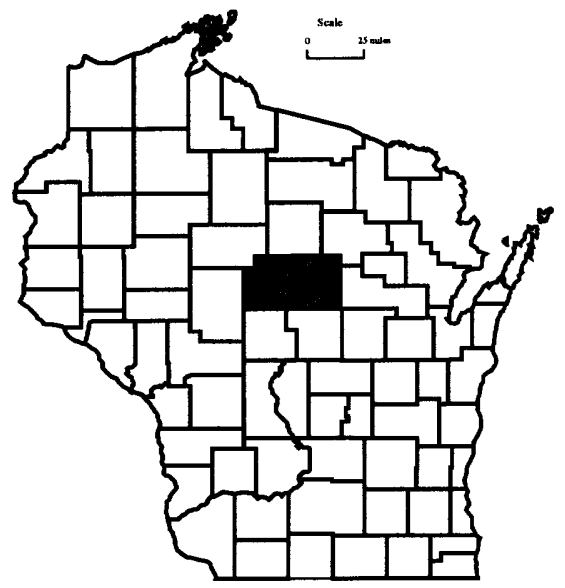




\section{EVALUATING IMPROVED STREET SWEEPING FOR ENHANCING WATER QUALITY IN HIGHWAY RUNOFF IN MILWAUKEE, WI 17231}

\author{
COOPERATOR: \\ Wisconsin Department of \\ Transportation
}

LOCATION:

Milwaukee County

PROJECT CHIEF:
Robert J. Waschbusch

PERIOD OF PROJECT: October 1998 to July 2001

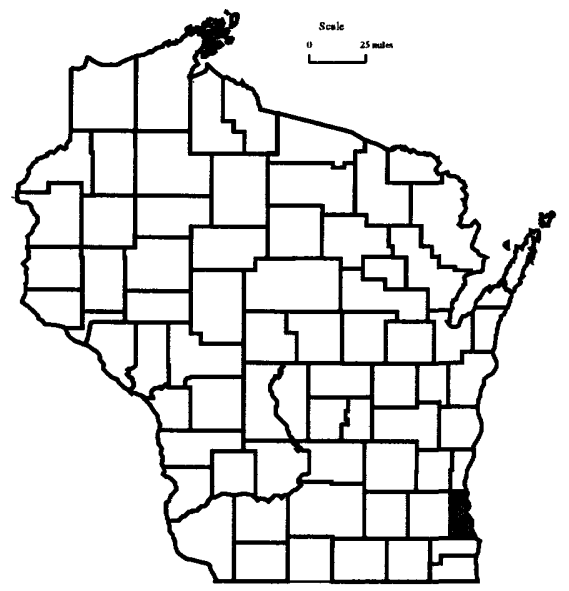

PROBLEM: The Wisconsin Department of Transportation (WDOT) is required to control the quality of runoff from roadways under their control as part of the National Pollutant Discharge Elimination System (NPDES). One way to control roadway runoff quality is to use street sweeping to remove pollutants before they are entrained in runoff. This option may be more cost effective than structural BMPs since WDOT already conducts street sweeping and would only need to increase the frequency of sweeping and use an improved sweeper.

OBJECTIVES: The primary objective of the investigation is to determine if water-quality benefits are realized by improved street sweeping and, if so, to what degree. Secondary objectives are to (1) develop accumulation curves for solids deposited on freeways in the greater Milwaukee area, (2) use solids accumulation curves and water-quality data to calibrate the SIMPTM model, (3) characterize the variability in freeway runoff quality, and (4) characterize pollutant loading with and without the street-sweeping program.

APPROACH: This study will use a paired-basin approach. The test basin will be swept periodically with an Enviro-Whirl street sweeper and the control basin will never be swept. Regression relations will be determined between the test and control basins for both sweeping and non-sweeping periods. If the slope and intercept of the regression relations are significantly different between the sweeping and non-sweeping periods, the difference will be attributed to street sweeping.

Baseline periods, where no sweeping occurs in either the test or control basin, will be used to define pollutant load and concentration relations for runoff events between the basins. These relations will then be compared to pollutant load and concentration relations found between the basins during test periods. Sweeping periods will have the test basin swept at a rate of once per week and the control basin unswept. The sweeping and non-sweeping schedule has been selected to provide an equal number of sweeping versus nonsweeping samples from frontal, convective and winter runoff events.

PROGRESS (July 2000 to June 2001): A total of 48 runoff samples have been collected from both the test and control basins. Flow, rainfall and traffic count data have been compiled for each of these events. In addition, street dirt samples were collected bi-weekly from the street shoulder surface from both basins. These samples were weighed and sieved to determine if street dirt masses and particle-size distributions are affected by the street-sweeping schedule. Preliminary data analysis has beerı performed on the runoff concentration data and the results presented at the Fox-Wolf 2000 stormwater conference in Green Bay in February 2001. A preliminary draft of a water-resources investigation report is being prepared.

PLANS (July 2001 to June 2002): Data analysis will be finalized and a report will be published and given to the WDOT about June 2001. The USGS will then assist the WDOT in the preparation of an interpretive report for WDOT purposes. 


\section{QUANTIFICATION OF SOLIDS LOADING FROM RESIDENTIAL AND COMMERCIAL CONSTRUCTION SITES IN DANE COUNTY, WISCONSIN, WI 17232}

PROBLEM: Construction site erosion has been identified as a significant source of suspended solids in runoff in many parts of the United States (Hagman and others, 1980; Yorke and Herb, 1976; Becker, et al., 1974). The literature reflects studies done on largescale projects including highway construction and plat development. There is limited information on the smaller residential and commercial sites, which typically range in size from one to five acres.

The project is designed to provide both national and local benefits. This study would provide the U.S. Environmental Protection Agency (USEPA) with specific data relating to the impact of sites less than five acres (small sites), which may facilitate implementation of Phase II of the USEPA National Pollution Discharge Elimination System (NPDES) standard for pollution control from small (less than five acre) construction sites.

OBJECTIVE: The four objectives for this project are to (1) quantify solids loading from one residential construction site and one commercial construction site during all construction phases from pre-construction through final landscaping, (2) determine whether the "first flush phenomenon" is responsible for significant sediment loading during storm events, (3) determine the particlesize distribution of the transported sediment during different stages of the hydrograph to determine preferential delivery of particles and (4) compare USLE/RUSLE (Universal Soil Loss Equation/Revised Universal Soil Loss Equation) modeled results to monitored data.

APPROACH: Discharge and associated solids concentrations and loads will be measured at two small, hydrologically-isolated sites. One residential and one commercial construction site in Dane County, Wisconsin, will be monitored. Data will be collected prior to construction, during construction, and after final landscaping so that a complete time-series of solids loading will be obtained during all phases of building construction. Photographic documentation will occur during all phases.

Discharge will be measured using a Parshall flume equipped with a transducer and datalogger in a drainage ditch down gradient of the residential site that is the single discharge point for runoff. Due to the potential variation on the larger commercial site, the sampling location will be selected based on the best available collection point. Samples for analysis of suspended solids will be collected using ISCO automated samplers set to collect samples at five-minute intervals during storm events. Particle-size distribution analyses will be conducted on the runoff samples.

PROGRESS (July 2000 to June 2001): Data and waterquality samples were collected at the BMP evaluation site until August 2000. A summary data report was submitted to the USEPA.

PLANS: Project is complete.
COOPERATOR:

Dane County Land Conservation

Department

LOCATION:

Madison and Sun Prairie

PROJECT CHIEF:

David W. Owens

PERIOD OF PROJECT:

May 1998 to December 2000

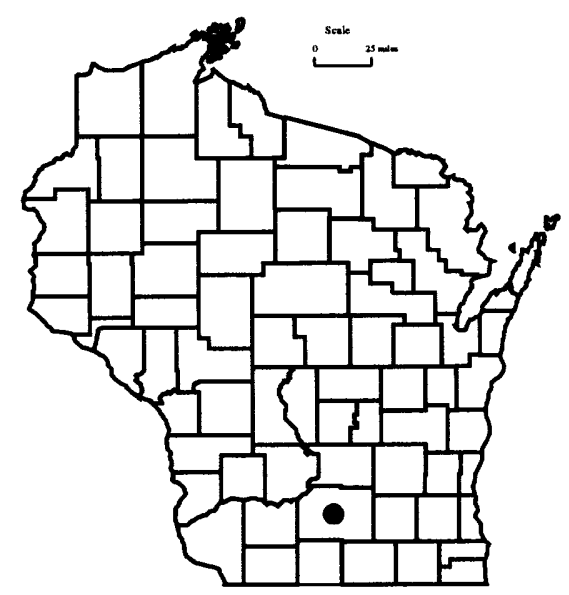




\section{EVALUATION OF THE EFFECTIVENESS OF LOW IMPACT DEVELOPMENT PRACTICES, WI 17233}

\author{
COOPERATOR: \\ Wisconsin Department of \\ Natural Resources

\section{LOCATION: \\ Cross Plains}

\section{PROJECT CHIEF: \\ William R. Selbig}

\section{PERIOD OF PROJECT:} July 1998 to September 2005

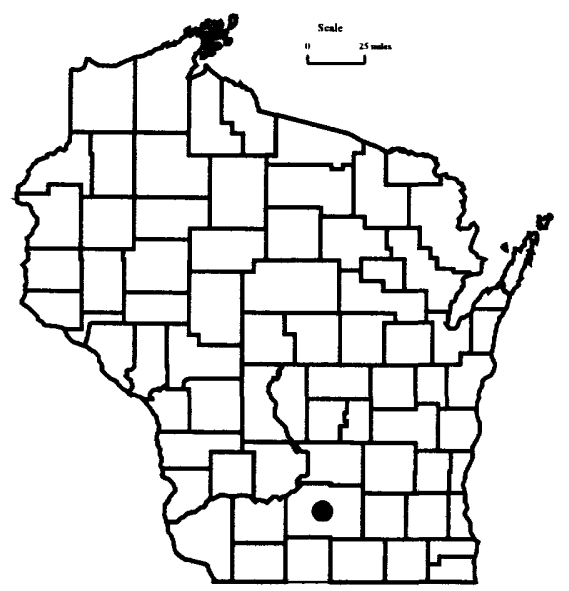

PROBLEM: Farmland in Wisconsin is rapidly being converted to urban land uses. This urban development, with the associated increase in impervious area, generally impacts the water quality and increases the runoff volume that is delivered to the receiving waterbody. When new site plans are proposed, many of the plans use "end-of-pipe" structural Best Management Practices (BMPs) such as wet and dry detention ponds. These stormwater controls, however, are primarily designed to reduce the flood peak of a runoff event. They have little effect on the volume of runoff.

Low-impact development practices are designed to reduce the volume of runoff. This not only reduces peak flows but also preserves the natural hydrology of the site. These low-impact practices include the reduction of impervious surfaces and installation of infiltration devices, such as rain gardens.

OBJECTIVE: The objective is to evaluate the effectiveness of low-impact practices for reducing runoff quantity and improving runoff water quality.

APPROACH: A test and control site has been selected in Cross Plains, Wisconsin. The control site, which was developed from 1988 to 1991 , used traditional urban design practices such as storm sewers, curbs and gutters, and a wet detention basin. The second site is being developed using low-impact practices. Both sites are finger valleys that are approximately a quarter mile apart.

Equipment at both sites will be installed and maintained to continuously monitor water level, precipitation, and water temperature. An automatic water-quality sampler will be installed at each site to take flow proportional samples. Water-quality samples for the majority of the runoff events will be analyzed for total and suspended solids, and total phosphorus. Periodically, samples from each site will be processed for particle-size distribution and selected total metals. All equipment at each site will be installed in a gaging station that will have phone telemetry and electrical power.

Comparisons will be made between the BMPs based on unit-area runoff and unit-area loads. Furthermore, the data collected during the seven-year period will document the changes in water quality and quantity during the construction cycle (from platting to site closeout).

PROGRESS (July 2000 to June 2001): Monitoring was continued at both sites during the subdivision platting phase and initial home construction at the rural site. Digital photos of construction activities are maintained on the USGS web site. A series of infiltration tests were performed on the infiltration practice to estimate the range of expected infiltration rates. 
PLANS (July 2001 to June 2002): We will continue to monitor both sites. Additional monitoring equipment will be installed at the three pond inlets, the pond outlet and in the infiltration practice. Individual source areas such as grassed swales, lawns, and curb-cut inlets will be monitored to isolate and determine the benefit of individual conservation design practices. 


\section{TEMPERATURE MODELING OF URBAN STORMWATER RUNOFF, WI 17234}

COOPERATOR:

Wisconsin Department of

Natural Resources

LOCATION:

Cross Plains

PROJECT CHIEF:

David W. Owens

PERIOD OF PROJECT: July 1998 to September 2000
PROBLEM: Rainwater that falls on urban surfaces during the warm summer months tends to collect heat from those urban surfaces. The heated rainwater tends to drain quickly to storm sewers and then into streams or lakes. When the receiving water body is a cold water fishery, the thermal load can have a detrimental effect.

OBJECTIVE: The objective is to develop a model that can estimate the thermal heating of rainwater from urban surfaces during the summer months.

APPROACH: Sensors will be installed to monitor surface temperatures at a wide variety of thermal source areas in a drainage basin in Cross Plains, Wisconsin. These thermal source areas include roofs, streets, driveways and lawns. Furthermore, a variety of source area materials (asphalt, concrete, metal, etc.) and colors (light and dark) will also be monitored. The continuously collected data will document the changes in surface temperature and in the runoff water as the runoff water moves through the conveyance system. The data collected will be used to develop a model that will estimate the thermal impact of different urban surfaces.

PROGRESS (July 2000 to June 2001): Additional temperature data was collected until August 2000. The water temperature model was calibrated to several runoff events that occurred during the summer of 1999. Model and monitoring documentation was completed during this time frame. The final model and documentation was completed during this time frame. The final model and documentation was submitted to the USEPA for approval.

PLANS: Project is complete.

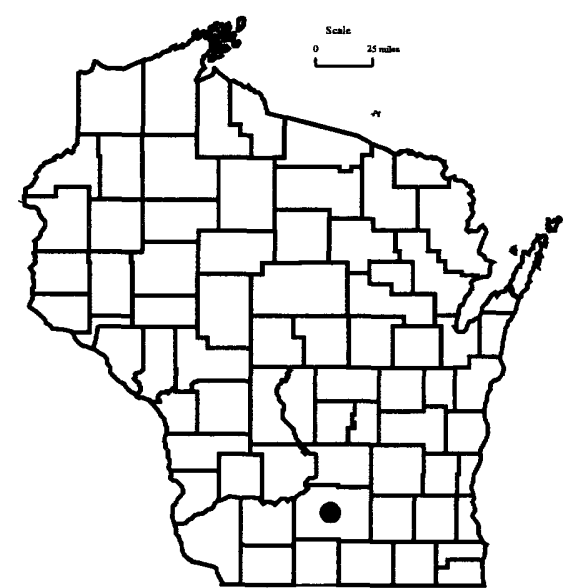




\section{IMPACTS OF RESIDENTAL CONSTRUCTION ON STREAM WATER QUALITY, WI 17235}

PROBLEM: Population in Dane County, Wisconsin, is growing at a fast pace. Farmland is being taken out of crop production and being replaced with urban land uses. During this urbanization, large tracts of land are being disturbed to create new subdivisions for residential housing. This disturbance can have a negative impact on instream water quality and quantity such as sedimentation and higher temperature. Quantification of these changes needs to be documented to reduce future in-stream impacts.

OBJECTIVE: The main objective of this project is to determine the "in-stream" impacts of residential urbanization on a small stream in Cross Plains, Wisconsin. Additional objectives include (1) comparing the sediment load estimated by the Universal Soil Loss Equation (USLE) and the Revised Universal Soil Loss Equation (RUSLE) to monitored data and (2) determining the changes in hydrology of the site by quantifying variation in peak flows as related to changes in drainage basin surface characteristics caused by the construction activities.

APPROACH: Discharge, and associated solids and phosphorus concentrations and loads will be measured both upstream and downstream of a 40-acre site that will be converted from agricultural to residential land use. Water-quantity, water-quality, and land-use data will be collected at a site located immediately upstream of the residential development and at an existing USGS gaging station (Brewery Creek at Cross Plains, 05406470) located immediately downstream of the development. Monitoring will be done prior to construction, during construction, and after construction. Waterquality analyses include total suspended solids, total phosphorus, and particle-size distribution. Before and after event mean concentrations from the upstream and downstream sites will be statistically compared.

PROGRESS (July 2000 to June 2001): Monitoring of the pre-construction phase of the project was continued. A third monitoring station was installed between the upstream and downstream site to measure runoff quantity and quality from a sub-basin to the proposed development. This sub-basin currently drains an agricultural field consisting of row crops. This effort will help quantify the unit-area load contribution of the existing conditions prior to construction activity. A digital camera was installed to photo document construction activities.

PLANS (July 2001 to June 2002): Monitoring and photo documentation activities will continue during the construction phase of the project.
COOPERATOR:

Dane County Land Conservation

Department

LOCATION:

Cross Plains

PROJECT CHIEF:

William R. Selbig

PERIOD OF PROJECT:

April 1999 to September 2004

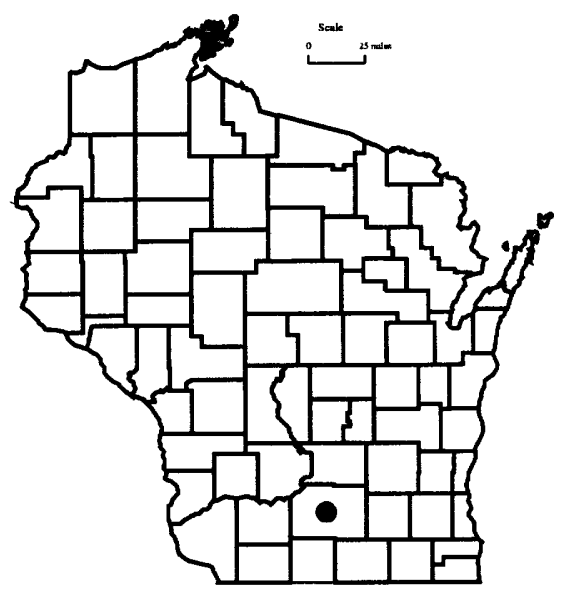




\section{ROCK RIVER PHOSPHORUS, WI 17236}

\author{
COOPERATORS: \\ City of Fort Atkinson \\ Rock River Watershed Publicly- \\ Owned Treatment Works (66.30) \\ Group \\ Wisconsin Department of \\ Natural Resources
}

LOCATION:

Rock River Basin

\section{PROJECT CHIEF:}

William R. Krug

PERIOD OF PROJECT:

July 1998 to September 2000

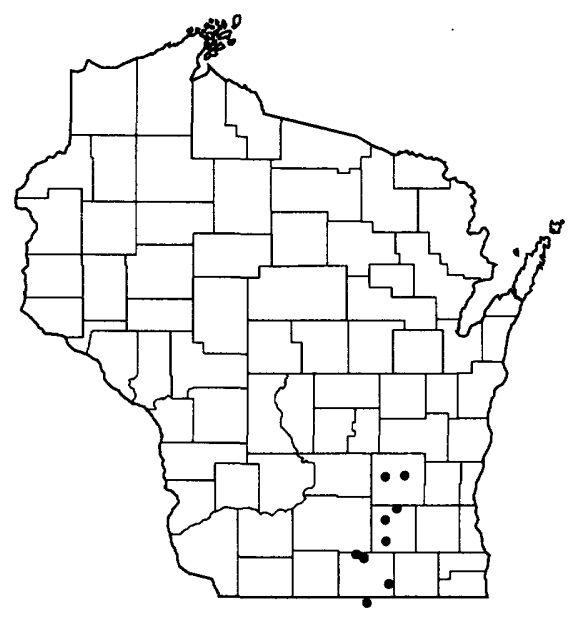

PROBLEM: Water quality of the Rock River depends on the load of nutrients contributed to the river by various sources. Sound management of water quality requires knowledge of the contributions of various sources to the total load of the river.

OBJECTIVE: The objective is to determine concentrations of various water-quality constituents at nine sites in the Rock River Ba$\sin$ in Wisconsin and to calculate loads for dissolved reactive phosphorus, total phosphorus and suspended solids.

APPROACH: Water-quality samples will be collected by staff of the cooperating treatment works twice each month, and at additional times when there is significant runoff. These data will be used to compute loads of the following constituents until August 1999:

5-day Biological Oxygen Demand

Dissolved Chloride

Chlorophyll $a$

Fecal Coliform

Dissolved Ammonia

Nitrate + Nitrite

Dissolved Reactive Phosphorus

Total Dissolved Solids

Total Kjeldahl Nitrogen

Total Phosphorus

Suspended Solids

Volatile Suspended Solids

Data will be used to compute loads for the following constituents from September 1999 to August 2000:

5-day Biological Oxygen Demand

Nitrate + Nitrite

Total Phosphorus

Dissolved Reactive Phosphorus

Suspended Solids

Volatile Suspended Solids

Loads were computed for suspended solids, total phosphorus, and dissolved reactive phosphorus.

PROGRESS (July 2000 to June 2001): Water-quality samples were collected and analyzed twice each month, with additional samples during significant runoff. Loads for three constituents were calculated for the period August 1998 through September 2000, and published in the annual data report.

PLANS (July 2001 to June 2002): A brief final report will be prepared explaining the data-collection procedures and summarizing the loads computed. 


\section{EVALUATION OF STREET SWEEPING AS A WATER-QUALITY MANAGEMENT TOOL IN RESIDENTIAL BASINS IN MADISON, WI 17237}

PROBLEM: The city of Madison is required to control the quality of stormwater runoff as part of the National Pollution Discharge Elimination System (NPDES). Previous studies have indicated that runoff from street surfaces is a major contributor of pollution in the city (Waschbusch et. al. 1999). One way to control roadway runoff is to use street sweeping to remove pollutants before they are entrained in runoff. This option may be preferable to structural Best Management Practices (BMPs) since structural BMPs can be expensive and often require land. In addition, the city already conducts street sweeping and may only need to modify their sweeping practices.

OBJECTIVE: The primary objective of this project is to determine if the dirt load on residential streets is reduced by various street sweeping scenarios and if so to what degree. Water-quality samples will be collected from two basins to determine if water-quality benefits are realized by the street-sweeping program and to what extent. The water-quality sampling results from these basins and the street dirt load data will be used to estimate the benefits that may be achieved using the other street-sweeping programs.

Secondary objectives are to characterize street dirt loadings with and without the street-sweeping program from residential streets and characterize the water quality in street runoff from residential watersheds.

APPROACH: This study will use a paired basins approach, meaning that data will be collected from three basins and then compared to each other. One basin will be the 'control' basin and will have minimal sweeping. The data from the other two basins (the 'test' basins), which will have various sweeping regimens implemented, will be compared to data from the control basin.

The three basins will be swept as follows: (1) one will have no sweeping except at the start of the equilibration periods (this will be the control basin); (2) the next basin will be swept using a new generation sweeper; and (3) the last will have sweeping as is currently done throughout the city. The basins listed in items $2-4$ are the test basins.

The USGS will collect vacuum samples once a week from three study basins for the duration of the study. These samples will be collected using equipment and methods similar to that described in Pitt (1979) and Waschbusch et. al. (1999). During the sweeping periods, samples will be collected immediately before the street sweeping occurs and immediately after. Street dirt data will be used to determine the pick-up efficiency of the street sweepers and the rate of dirt build-up on and wash off from the streets. The USGS will dry, sieve and weigh the vacuum samples. The samples will be sieved through a $62 \mu \mathrm{m}$ screen to determine the fraction that is above and below sand size. The sieved dirt data will be used to see if there is a difference in the collection efficiency of the two size fractions between the new generation sweeper and sweepers currently used.
COOPERATOR:

Wisconsin Department of

Natural Resources

LOCATION:

Dane County

PROJECT CHIEF:

William Selbig

PERIOD OF PROJECT:

May 2001 to June 2002

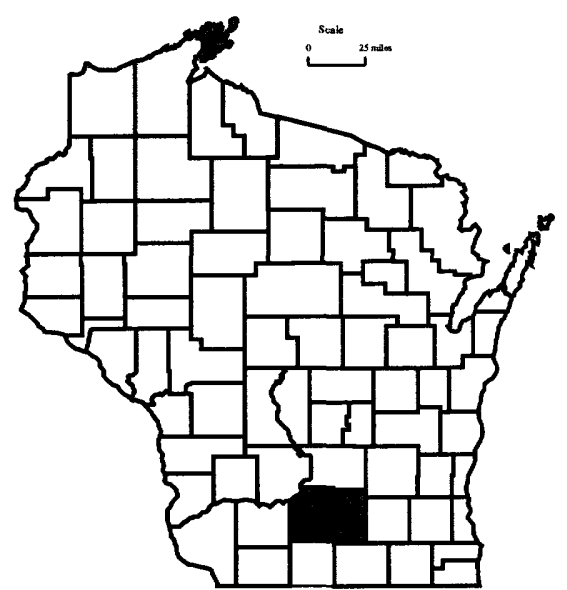


In addition to the street dirt sampling, the control basin and the basin with the most intense street-sweeping program will have water-quality samples collected and compared. The two basins will be equipped with data loggers, flow measurement devices or structures, phones, modems, ISCO samplers, and raingages. AC power will be necessary for battery chargers, refrigerated samplers, heating tapes on sampler intakes and possibly area-velocity meters.

Sweeping periods will have the test basins swept at a rate of once per week and the control basin unswept except at the beginning of an equilibration period. The city of Madison will be responsible for getting the streets swept on schedule. On days when it is raining or snowing, the street sweeping will be delayed for a day or two until the streets are dry. The sweeping schedule has been selected to provide an equal number of sweeping versus non-sweeping samples from spring, summer and fall runoff events.

PROGRESS (May 2001 to June 2001): Preliminary meetings with Wisconsin DNR and city of Madison to develop final scope of project were held. Field reconnaissance to locate the control and test basins for water-quality monitoring was conducted. Potential streets were identified within the area of study to evaluate the effectiveness of street sweepers under varying parking regulations.

PLANS (July 2001 to June 2002): Outfall and street-monitoring equipment within the control and test basins will be installed. Initial vacuum collection will begin to coincide with street-sweeping activities. 


\section{MONITORING CONTAMINANT FLUX FROM A STORMWATER INFILTRATION FACILITY TO GROUND WATER, WI 17238}

PROBLEM: Wisconsin is in the process of finalizing administrative code NR 151 which will in part define performance standards for infiltration of stormwater from new development. The stormwater infiltration standards are intended to preserve stream baseflow and ground-water recharge. However, depending on the characteristics of a drainage area, infiltration of stormwater may introduce significant amounts of contaminants to ground water including hydrocarbons, pesticides, bacteria, and chloride. Because of the impending performance standards for infiltration, it is imperative to quantify the relation between quality of infiltrated stormwater and the flux of contaminants to the ground-water system.

OBJECTIVE: The objective of the proposed study is to quantify through field data the relation between the quality of infiltrated stormwater and the flux of contaminants through the unsaturated zone to ground water.

APPROACH: A recently constructed infiltration trench in Cross Plains, Wisconsin, will be instrumented and monitored for the collection of hydrologic and water-quality data (once permission for access is granted). The trench serves runoff from a well-defined area comprised primarily of a gas station/convenience store parking lot and is expected to have stormwater runoff with a relatively high concentration of a variety of contaminants. Preliminary plans call for the installation of equilibrium tension lysimeters at two different depths below the infiltration trench. Monitoring and sampling of lysimeter leachate, stormwater and ground water will be carried out using a combination of automated and manual means. Data gathered over the course of this study will be compiled and interpreted to characterize the flux of infiltrated contaminants to ground water. Important relations between stormwater quality and contaminant flux will be evaluated.

PLANS (July 2001 to June 2002: Two lysimeters will be installed underneath the infiltration trench at the Cross Plains site using current methodology. This will require digging up a portion of the trench, installing the lysimeters and associated lines and equipment, and then reconstructing the trench. At the same time well points will be installed with screens across the water table under the infiltration trench and at several points down gradient. These well points will be used as water-quality-sampling points. In addition, there is currently a perforated stand pipe in the infiltration trench that runs from the surface to at least the bottom of the gravel fill. This stand pipe will give a reasonably well-integrated sample representing the quality of the infiltrated stormwater. With this equipment in place, water-quality samples can be taken of stormwater, leachate from the unsaturated zone and water table. Initial water-quality samples will serve to check the integrity of the lysimeters and well points, and provide a measure of initial contaminant concentrations. Water-quality sampling may be conducted at regular time intervals, in response to an infiltration event or in both instances. Discussions concerning this issue continue.
COOPERATOR:

Wisconsin Department of

Natural Resources

LOCATION:

Dane County

PROJECT CHIEF:

Charles Dunning

PERIOD OF PROJECT:

July 2001 to June 2002

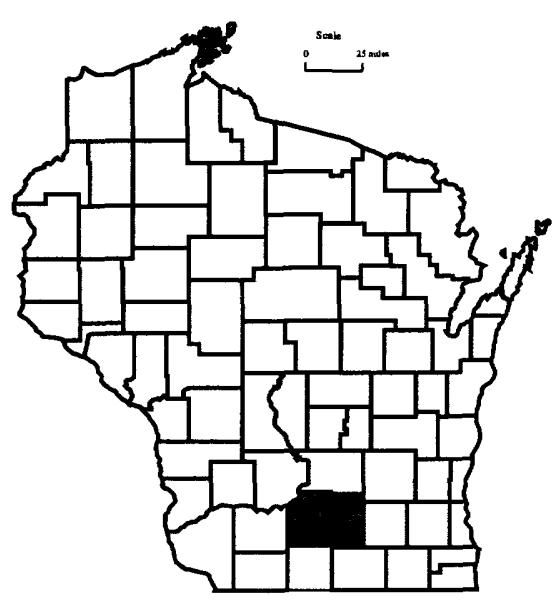




\section{ASSESSMENT OF THE HYDROLOGY AND WATER QUALITY OF, AND PHOSPHORUS LOADING TO, PIKE LAKE IN WASHINGTON COUNTY, WI 17301}

COOPERATOR:

Pike Lake Management District

\author{
LOCATION: \\ Southwestern Washington \\ County
}

\author{
PROJECT CHIEF: \\ William J. Rose
}

\section{PERIOD OF PROJECT:}

October 1998 to December 2001
PROBLEM: The following are issues of concern: near-bottom phosphorus concentrations in the lake appear to be increasing over time, indicating possible increasing phosphorus release from lake sediments; trophic state of the lake is borderline mesotrophiceutrophic and information on various phosphorus loading sources and rates are not available to evaluate potential changes in lake condition under present, increased, or decreased loading scenarios; the effects of increasing development in the watershed and resulting increasing storm runoff and discharge from wastewater treatment plants into the Rubicon River are unknown; the effectiveness of the present partial inlet diversion or short-circuiting of inflow to the outlet is unknown; and the potential for additional phosphorus load reduction to the lake with enhanced diversion is unknown.

OBJECTIVE: Objectives are to define the hydrology and water budget of the lake, determine the phosphorus loads from various sources and develop a phosphorus budget for the lake, assess the effectiveness of the inlet diversion and potential for improved diversion, and evaluate the effects of increases or decreases in phosphorus loading on the trophic status of the lake.

APPROACH: The study will consist of gage installation and two years of data collection followed by data analysis and report preparation. Data collection will be done from December 1998 through October 2000. Flow and water-quality data will be collected at the Rubicon River inlet to, and outlet from, the lake and at selected other inflows. These data will be used to describe the hydrology and water budget of the lake, calculate an annual phosphorus budget for the lake and evaluate effects of loading changes on the lake's trophic status. In-lake water-quality data will be provided by the Wisconsin Department of Natural Resources.

PROGRESS (July 2000 to June 2001): The slated two years of streamflow and water-quality monitoring was completed in November 2000. Preliminary water and phosphorus budgets were computed. The Rubicon River was the dominant source of phosphorus entering the lake. However, much of that phosphorus (about 70 percent) was "short circuited" to the lake's outlet, which effectively reduced the net loading to the main body of the lake.

PLANS (July 2001 to June 2002): The final interpretive report on the study will be prepared for the lake district. Data will be published in the annual report "Water Resources Data-Wisconsin". 
PROBLEM: Monitoring miscellaneous, single hydrologic aspects of lakes is needed, but does not warrant establishing separate projects or subprojects. This monitoring is typically narrow in scope, such as flow or loading from a single lake tributary or lake stage, and is usually a prelude to, or follow-up from, a more comprehensive lake study.

OBJECTIVE: The objective is to collect lake stage, streamflow, stream-water quality, and constituent load data as needed. These lake-related monitoring efforts will be managed and financially tracked in this subproject of WI 17300.

APPROACH: Monitoring that fits into this subproject will be done using appropriate standard USGS practices. A streamflowgaging station will be operated and loads of Jewel Creek, a tributary of Little Muskego Lake in Waukesha County, will be monitored.

PROGRESS (July 2000 to June 2001): Monitoring of flow, phosphorus loading, and suspended-sediment loading to Little Muskego Lake at the mouth of Jewel Creek continued. Monitoring of flow, sediment and phosphorus from Big Muskego Lake continued. Lake-stage monitoring at Whitewater and Wind Lake continued. Four piezometers with recorders were installed at Devil's Lake.

PLANS (July 2001 to June 2002): Monitoring at last year's sites will continue. Data will be published in the annual report "Water Resources Data-Wisconsin".

\section{COOPERATOR:}

City of Muskego

Little Muskego Lake Management

District

Whitewater/Rice Lakes

Management District

Wind Lake Management District

LOCATION:

Statewide

PROJECT CHIEF:

William J. Rose

PERIOD OF PROJECT:

October 1998-Continuing

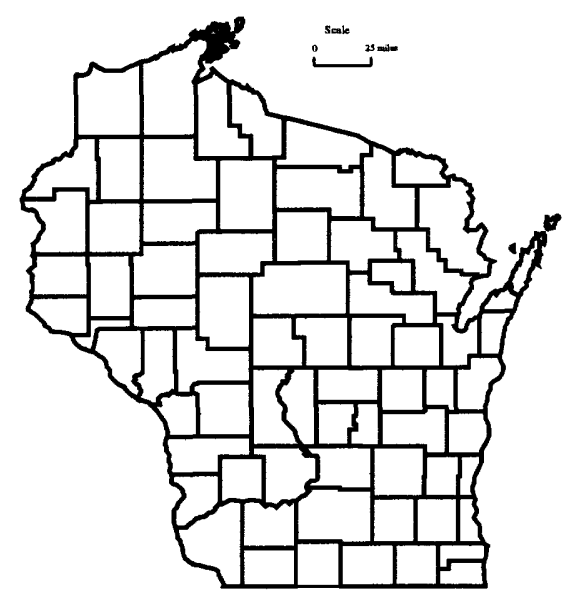




\section{WISCONSIN LAKES, GREEN LAKE TRIBUTARY MONITORING WI 17303}

\author{
COOPERATOR: \\ Green Lake Sanitary District
}

\section{LOCATION:}

Green Lake County

PROJECT CHIEF:

William J. Rose

PERIOD OF PROJECT: October 1977-Continuing

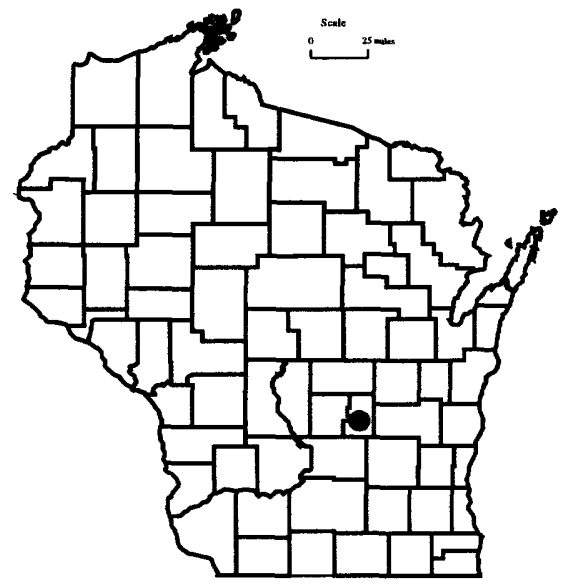

PROBLEM: Silver Creek is the primary source of phosphorus to Green Lake. Continued documentation of suspended sediment and phosphorus loads from major tributaries helps to explain the lake's water quality. Data are needed to determine changes in loads over time and loading variability in relation to streamflow.

OBJECTIVE: The objectives of this project are to determine suspended sediment and phosphorus loads in relation to streamflow in selected tributaries to Green Lake.

APPROACH: Streamflow will be monitored continuously at selected sites. Water-sediment samples will be collected manually and by automatic samplers during storm runoff. Suspended-sediment and nutrient concentrations will be determined. Daily, monthly, and annual mean suspended-sediment and nutrient loads will be computed.

PROGRESS (July 2000 to June 2001): Streamflow and water quality were monitored at the Silver Creek inlet to Green Lake and at the mouth of White Creek. The Silver Creek site is equipped with an acoustic velocity meter, a stage gage, and an automatic water sampler. The White Creek site is a conventional stream-gaging site and is equipped with an automatic water sampler. Streamflow, phosphorus, and suspended-sediment loading to the lake were determined for both sites.

A gage on the Puchyan River near the outlet of Green Lake was operated to monitor flow from the lake. Water samples were collected manually for phosphorus analysis. Streamflow, load and concentration data were published in the report "Water Resources DataWisconsin".

PLANS (July 2001 to June 2002): Streamflow and waterquality monitoring at the Silver Creek and White Creek inlets and at the Puchyan River outlet will be continued. Streamflow, phosphorus, and suspended-sediment loads will be published in the annual report, "Water Resources Data-Wisconsin". 


\section{POOL 8 GROUND-WATER/SURFACE-WATER STUDY, WI 17304}

PROBLEM: Nitrogen loading and transformation in the Upper Mississippi River (UMR) system has recently become an issue of concern. The influence of ground water on the loading and transformation is poorly known, primarily due to the difficulty in quantifying the location and magnitude of ground-water/surface-water interaction and lack of knowledge regarding nitrogen concentrations contained within the ground water. The interactions of ground water and surface water, however, may influence the occurrence and rates of nitrate reactions in the Upper Mississippi River system.

OBJECTIVE: The project objectives are to (1) determine magnitude of ground-water discharge and nitrate loading via ground water to the Pool, and (2) delineate important contributing areas for the Pool.

APPROACH: The investigation is conducted using a stepwise approach where a model will initially be developed using existing data. Results of the initial model are then used to guide future data collection, which is used to update the model. The initial groundwater-flow model will be constructed using analytic element methods. Different system conceptualizations will be tested by coupling the analytic element model to a parameter estimation code. The field work will include on-shore installation of permanent well nests to characterize the local and regional ground-water systems, installation of temporary well nests within Pool 8, installation of thermocouple strings in areas of suspected high ground-water discharge rates to measure ground-water-flow velocities, and collection of ground-water samples for nutrient analyses and age dating. After the field work phase, the analytic element model will be updated and refined. The analytic element model will then be translated to a threedimensional model using the finite-difference code MODFLOW. The resulting three-dimensional model and geochemical sampling will be used to construct maps of ground-water discharge, flowpaths, travel times, and ground-water quality.

PROGRESS (July 2000 to June 2001): Ground-water-level data collection has continued. The analytic element model has been refined in the respective basins that make up the Pool 8 system to assess gradations in ground-water recharge.

PLANS (July 2001 to June 2002): A three-dimensional MODFLOW model will be extracted from the analytic element model and will be calibrated to the ground-water-level data collected during the study. Ground-water discharge zones and magnitude of ground-water flux and associated nitrate loading will be determined using the calibrated model.
COOPERATOR:

U.S. Geological Survey, Water

Resources Division, National

Stream Quality Accounting

Network Program

LOCATION:

Southwestern Wisconsin

PROJECT CHIEF:

Randy J. Hunt

PERIOD OF PROJECT:

May 1999 to September 2001

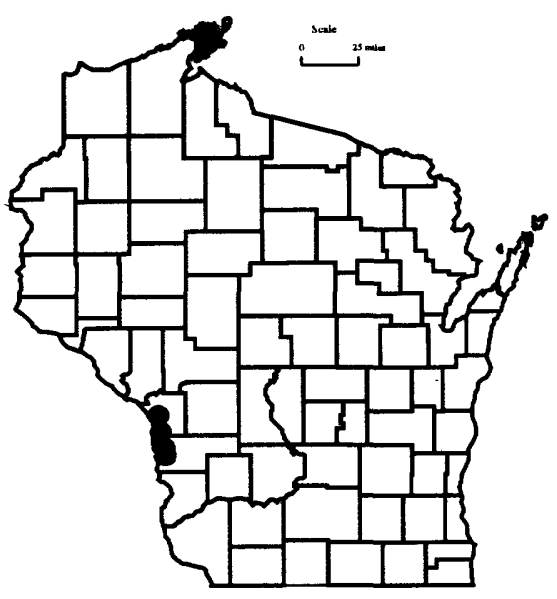




\section{HYDROLOGIC INVESTIGATION OF SILVER LAKE, WI 17305}

COOPERATOR:

Silver Lake Protection and

Rehabilitation District

\section{LOCATION:}

Washington County

\section{PROJECT CHIEF: \\ Charles Dunning}

PERIOD OF PROJECT:

October 1999 to September 2001
PROBLEM: An increased understanding of the hydrologic budget components of Silver Lake will help in developing a tool (waterbudget model) to test the understanding of the system and model the ground-water/surface-water interaction within the lake basin. This model will be used by the District as a tool in lake management decisions.

OBJECTIVES: Specific objectives are to (1) determine the hydraulic parameters and budget components of Silver Lake, (2) quantify the loading to the lake due to ground-water inflow, and (3) identify key ground-water recharge areas for Silver Lake.

APPROACH: Historical data will be used to develop a numerical ground-water-flow model of Silver Lake and its watershed. Water budget parameters to be included in the model are precipitation, evaporation, and measured water levels and flows. This model will be calibrated to lake stage and discharge. Based on previous models of this type, the hydraulic conductivity of the lake bed and runoff coefficients are the most likely parameters to be adjusted during the calibration process.

PROGRESS (July 2000 to June 2001): The analytic element model for the Silver Lake area has been completed, and results of the study have been presented to the Silver Lake Protection and Rehabilitation District.

PLANS (July 2001 to June 2002): A USGS water-resources investigations report is in preparation.

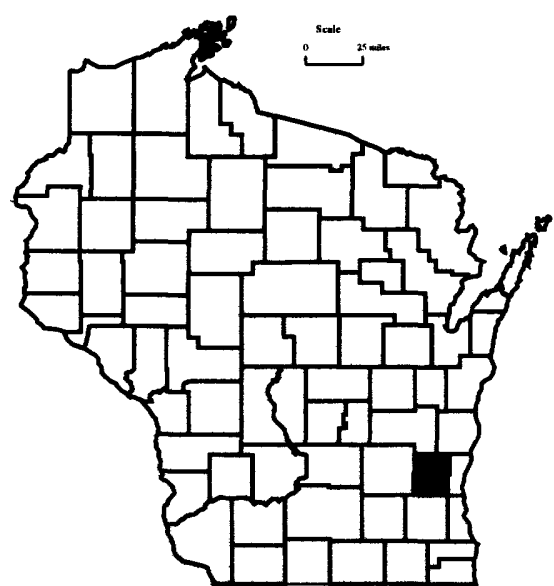




\section{FISH LAKE, DANE COUNTY, WI 17306}

PROBLEM: There has been a steady increase in the stage of Fish Lake over the last 25 years. The lake, located in northwestern Dane County, Wisconsin, is a 216-acre seepage lake having a maximum depth of 62 feet. The Fish Lake Association is concerned over the flooding of roads and near-shore residences caused by high lake stages. The Association has contemplated withdrawing lake water during high stage periods but a better understanding of the hydrology of the lake/ground-water system and the long-term effect of withdrawing lake water on lake stage are required before decisions can be made.

Estimates of the hydrologic budget components and hydraulic parameters (e.g., hydraulic conductivity and gradient and runoff and evaporation coefficients) of Fish Lake are essential in developing a tool (water-budget model) to predict the effects of withdrawing lake water on future lake stages. The model, when calibrated, will help answer the following questions: (1) will pumping at high stage affect future low stage; (2) would diversion of surface sources significantly reduce stage; and (3) how much pumping is needed?

OBJECTIVE: The objectives are to (1) demonstrate an understanding of the hydrology of Fish Lake by simulating lake stage using estimated hydrologic budget components and hydraulic parameters and (2) predict the possible effect of pumping water from Fish Lake on future lake stage.

APPROACH: A water budget model that calculates lake stage due to variations in budget components or withdrawal of lake water will be developed. Historical data will be used to develop a waterbudget model. This model will be calibrated to lake stage. The calibrated model will be used to predict the possible effect of pumping water from Fish Lake on future lake stage.

PROGRESS (January 2000 to June 2001): The model is calibrated and has been used to predict the effect of pumping water from Fish Lake on the future lake stage of both Fish and Crystal Lakes.

PLANS (July 2001 to June 2002): A report describing the model development and various simulations will be written, reviewed and published.
COOPERATOR:

Dane County Lakes and

Watershed Management

\section{LOCATION:}

Northwestern Dane County

PROJECT CHIEF:

Jim Krohelski

PERIOD OF PROJECT: January 2000 to September 2001

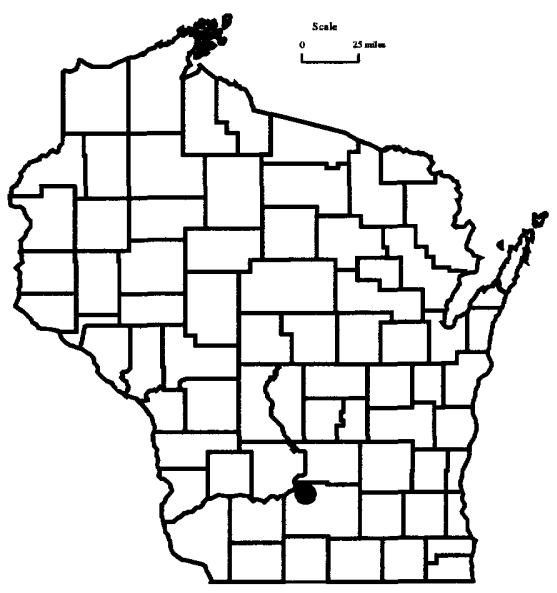




\section{CRYSTAL LAKE, DANE COUNTY, WI 17307}

COOPERATOR:

Dane County Lakes and

Watershed Management

LOCATION:
Dane County

PROJECT CHIEF:

Jim Krohelski

PERIOD OF PROJECT: January 2000 to September 2001
PROBLEM: Crystal Lake is a 500-acre seepage lake with a maximum depth of 9 feet and is located about 1/4 mile east of Fish Lake in Dane County. The Fish Lake Association has contemplated withdrawing lake water to mitigate flooding of roads and several nearby residences. Crystal Lake is probably hydraulically connected to the same shallow ground-water-flow system as Fish Lake. If withdrawing water from Fish Lake lowers the water table in the vicinity of Fish Lake, it may also cause an unwanted lowering of Crystal Lake stage.

OBJECTIVE: The objectives are to (1) demonstrate an understanding of the hydrology of the lake/ground-water system in the vicinity of Crystal, Fish and Mud Lakes by simulating measured lake stage, ground-water elevation and local streamflow and (2) predict the possible effect of pumping water from Fish Lake on Crystal Lake stage.

\begin{abstract}
APPROACH: A review of existing data that includes published reports and papers, available driller's construction reports and geological logs and unpublished data from other agencies such as the Wisconsin Geological and Natural History Survey will be conducted during the first few months of the study. These data will be used to determine the hydrogeologic framework and hydraulic parameters for model development. From this framework, a conceptual model of the interaction between the lakes and the ground-water system will be formulated. A numerical model of the lake(s) ground-water system will be used to test the validity of the conceptual model. Calibration of the ground-water-flow model will be obtained by comparison of previous ground-water gradient values and head and streamflow measurements to simulated values. After calibration, the model will be used in predictive mode to determine the effect of pumping or diversion from Fish Lake on Crystal Lake stage.
\end{abstract}

PROGRESS (July 2000 to June 2001): The model is calibrated and has been used to predict the effect of pumping water from Fish Lake on the future lake stage of both Fish and Crystal Lakes.

PLANS (July 2001 to June 2002): A report describing the model development and various simulations will be written, reviewed and published. 


\section{HYDROLOGIC INVESTIGATION OF POWELL MARSH AND ITS RELATION TO DEAD PIKE LAKE, WI 17309}

\begin{abstract}
PROBLEM: An extensive system of ditches and shallow ponds was constructed in Powell Marsh in the 1950s. The marsh is a large part of Dead Pike Lake's watershed. Lake area residents are concerned that the ditch and pond system has fostered the production of an iron precipitate and is damaging the aesthetic quality of the lake. The hypothesis is that iron, which is likely to be present in wetland soils, is being mobilized by anoxic conditions and locally increased ground-water gradients due to ditch and pond construction. Once the reduced iron reaches the main ditch draining to Dead Pike Lake, the iron is oxidized, forming the precipitate.
\end{abstract}

OBJECTIVE: The objectives are to (1) identify the chemistry (parameters that govern iron) of water at various points in the marsh, pond, aquifer, ditch, and lake system; (2) define the hydrology of the pond, marsh, aquifer, ditch, and lake system; and (3) determine the effects of lowering ground-water gradients near the ditch conveying the iron precipitate to Dead Pike Lake.

APPROACH: A first phase of the study will consist of reconnaissance, identification of site chemistry, monitoring, and development of a ground-water-flow model. The second phase will consist of monitoring, and model calibration and prediction. At the conclusion of the first phase, a meeting will be held with WDNR personnel and interested lake area residents to explain study findings and plans for the second phase. The second phase will include a report describing findings and results of model prediction. The model will be available to WDNR and the USGS, if required, will answer requests for additional model runs.

PROGRESS (May 2000 to June 2001): A meeting was held in April 2000 to review study plans with interested lake area residents and WDNR personnel. A preliminary ground-water model was set up to aid in identifying field data-collection sites. Field work, such as the measurement of stream flow, installation of piezometers, surveying altitudes of area streams and lakes, and collection and analysis of water samples, was done in June and July 2000. The model was calibrated and run to simulate conditions with the ditch and pond system and without the ditch and pond system in place. In a September 2000 meeting, findings were presented to interested lake area residents and WDNR personnel.

PLANS (July 2001 to June 2002): A report describing the significant findings and documenting data collection, model development and calibration, and the results of model prediction will be prepared.
COOPERATOR:

Wisconsin Department of

Natural Resources

LOCATION:

Vilas County

PROJECT CHIEF:

William J. Rose

Jim Krohelski

PERIOD OF PROJECT:

May 2000 to September 2001

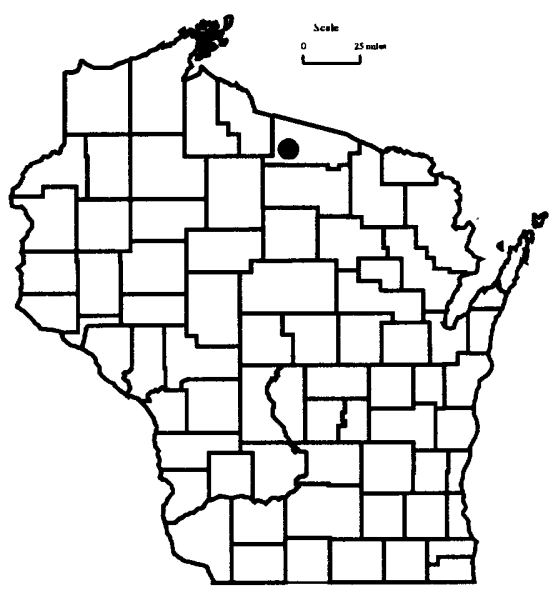




\section{LAUDERDALE LAKES RESTORATION MONITORING, WI 17310}

COOPERATOR:

Lauderdale Lakes Lake

Management District

LOCATION:

Walworth County

PROJECT CHIEF:

Herbert S. Garn

PERIOD OF PROJECT:

October 1998 to September 2002
PROBLEM: The Lauderdale Lakes Lake Management District is implementing actions and practices designed to reduce nutrient loading to the lakes from agricultural and near-shore residential sources. Actions include wetland restoration and enhancement, stormwater management practices, and lawn fertilization practices to demonstrate the feasibility of applying such techniques for protecting or improving the water quality of lakes in southeastern Wisconsin. The effectiveness of these practices is not known and needs to be determined.

OBJECTIVE: The objective is to conduct water monitoring needed to assess the results and effectiveness of selected practices being implemented to reduce phosphorus loading to these lakes.

APPROACH: Several types of monitoring will be conducted and will be used to evaluate the effectiveness of practices to be installed around the lakes to improve runoff water quality. Water-monitoring efforts include: (1) monitoring continuous discharge, total phosphorus and solids loads from an ephemeral tributary to Green Lake that will be receiving treatments to improve runoff quality, (2) monitoring in-lake water quality of Middle Lake to describe and quantify lake water quality during the restoration period, and (3) monitoring surface runoff from representative lawns around Lauderdale Lakes and determining the effect of various lawn fertilizing practices on phosphorus content of lawn runoff. Highly fertilized lawns, use of non-phosphorus fertilizer, and no fertilizer applications are the practices that will be evaluated.

PROGRESS (July 2000 to June 2001): Lawn runoff monitoring was conducted at 16 sites during the growing season to determine nutrient content; lawn monitoring was completed on September 30,2000. Up to 10 runoff events were sampled over the season and total phosphorus concentrations observed in lawn runoff samples were as high as $17 \mathrm{mg} / \mathrm{L}$. A continuous-recording gaging station with automatic water sampler was operated on an ephemeral stream on the northeast side of Green Lake. No flow occurred in the tributary during the year. Water-quality monitoring of Middle Lake was conducted. All data were received and published in the annual data report and lake data report for Water Year 2000.

PLANS (July 2001 to June 2002): A fact sheet will be prepared presenting the results of nutrient concentrations in runoff from lawn sites adjacent to Lauderdale Lakes. Lake sampling and runoff monitoring of the stream site will be continued and gaging station operated. Final records and loads will be computed for the water year. Data collected during the water year will be prepared for publication in the annual data report "Water Resources Data-Wisconsin." 


\section{WATER QUALITY OF THE RED CEDAR LAKES IN RESPONSE TO HYDROLOGIC AND PHOSPHORUS LOADING, WI 17311}

PROBLEM: In order to establish realistic water-quality goals for the Red Cedar Lakes (Balsam, Red Cedar, and Hemlock Lakes) accurate nutrient loading estimates are needed to enable water-quality models to be calibrated and used to develop response curves for the lakes. Each lake's response to incremental increases or decreases in phosphorus loading can be evaluated with calibrated models .

OBJECTIVE: The objectives of this project are to (1) quantify the phosphorus and sediment loading into and out of Balsam, Red Cedar, and Hemlock Lakes; (2) allocate the loading of phosphorus to its major contributing areas in the watershed or upstream lakes; and (3) determine the response of these lakes to present and future phosphorus loading scenarios. A better understanding of the relative contributions of phosphorus from critical locations and the response of the lakes to various scenarios will enhance the development of a lake-management plan for the Red Cedar Lakes.

APPROACH: Water quality (field parameters, nutrients, and chlorophyll) will be sampled six times per year in Balsam, Hemlock, and Red Cedar Lakes. In addition, a suite of water-quality parameters will be sampled at spring overturn. To estimate the nutrient loading at Birch Lake Outlet and Red Cedar Lake Outlet, streamflow will be estimated daily and samples will be collected 12 to 15 times per year. To estimate nutrient loading from direct river loading, two sites (Hemlock Creek and Sucker Creek) will have automated recording gages installed and will be sampled with automatic water samplers. Phosphorus load data at the stream sites will be used to estimate unit-area loads for unmonitored portions of the basins. These data will be used to develop complete hydrologic and phosphorus budgets for the Red Cedar Lakes. Concurrent water and phosphorus budgets for the lakes and in-lake water-quality data will be used to calibrate the Bathtub model for each of the lakes. The Bathtub model will be used to estimate the lakes' response to various phosphorus loading scenarios. With a calibrated model, the lakes' response to incremental increases or decreases in phosphorus loading can be evaluated.

PROGRESS (July 2000 to June 2001): All stream and water-level gages were installed and operated starting in October 2000. Water-quality sampling was conducted at all of the tributary sites and lake sites.

PLANS (July 2001 to June 2002): Sampling will be continued in each lake. Lake data will be compiled and published in the report, "Water-quality and lake-stage data for Wisconsin lakes". Stream sampling will be continued. Stream data will be compiled and published in the report "Water resources data-Wisconsin". Nutrient budgets will be developed and used to do Bathtub models for each lake.
COOPERATOR:

Town of Cedar Lake

LOCATION:

Washburn and Barron Counties

PROJECT CHIEF:

Dale M. Robertson

William J. Rose

PERIOD OF PROJECT: September 2000 to December 2002

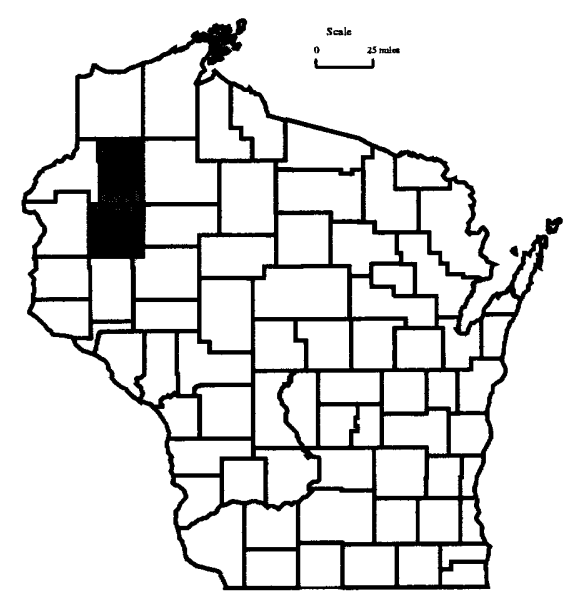




\section{ASSESSMENT OF PHOSPHORUS LOADING, WINTER ANOXIA, AND STAGE REGULATION OF LITTLE ST. GERMAIN LAKE, VILAS COUNTY, WI 17313}

COOPERATOR:

Little St. Germain Lake District

LOCATION:

10 miles west of Eagle River

PROJECT CHIEF:

William J. Rose

Dale M. Robertson

PERIOD OF PROJECT: August 1996 to June 2001

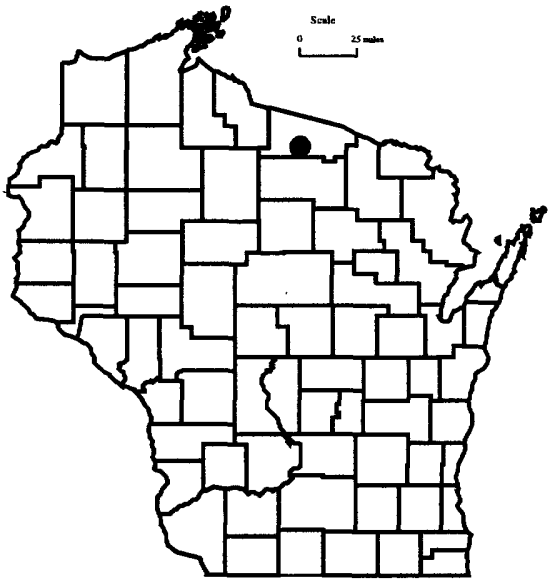

PROBLEM: Little St. Germain Lake consists of three main basins (East Bay, South Bay, and West Bay) separated by narrows. Muskellunge Creek, the lake's only inlet stream, enters East Bay. A dam at the lake's outlet is used to regulate lake stage and flow from South Bay. Hence, the net flow of water is from East Bay to South Bay. Summer water quality ranges from good to very good in the West Bay, fair to good in the South Bay, and poor to very poor in the East Bay, based on monitoring from 1992-1994. Dissolved oxygen was absent at the South Bay monitoring site in late winter each year from 1992-1994. The spatial and temporal extent of the oxygen problem was defined by a 1997-1999 study. The lake district is evaluating measures to improve water quality.

OBJECTIVE: The primary objectives of the study are to (1) continue the water-quality trend monitoring at sites in the four main basins of the lake, (2) continue monitoring to determine water and phosphorus loading to the lake from Muskellunge Creek, (3) identify sources of phosphorus to Muskellunge Creek, (4) determine spatial and temporal distribution of oxygen in winter before and after installation of aeration systems, (5) model groundwater/lake-water interaction and estimate loading of phosphorus to lake from ground water, and (6) synthesize all data, new and old, to evaluate the effectiveness of aeration systems and refine lake water and phosphorus budgets.

APPROACH: Flow in Muskellunge Creek will be measured and sampled intermittently (about monthly). Samples will be analyzed for concentration of total phosphorus. The data will be used to calculate the water and phosphorus loading to the East Bay. Extent of anoxia throughout the lake will be determined by measuring dissolved-oxygen profiles in late winter. Ground-water/lake-water interaction will be modeled with the two-dimensional model, GFLOW.

PROGRESS (July 2000 to June 2001): Data monitoring continued as scheduled. A report for the completed phase of the project was published. About 12 piezometers were installed around the periphery of the lake.

PLANS (July 2001 to June 2002): Monitoring to refine the lake's water and phosphorus budgets will continue as will the basic water-quality trend monitoring. Intensive dissolved oxygen monitoring in the upper East and South Bays of the lake will continue.

\section{REPORTS:}

Robertson, Dale M. and Rose, William J., 2000, Hydrology, water quality, and phosphorus loading of Little St. Germain Lake, Vilas County, Wisconsin: U.S. Geological Survey WaterResources Investigations Report 00-4209, 8 p. 


\section{ASSESSMENT OF THE WATER QUALITY, HYDROLOGY, AND BIOLOGY OF GENEVA LAKE, WI 17314}

PROBLEM: Concerns have arisen over the potential decline in the water quality of Geneva Lake because of increased urban development and recreational use. The public perception is that the water quality of Geneva Lake is declining; however, little direct evidence is available to support or deny the perceptions. To reduce the impact on the lake, efforts are being made to decrease the point and nonpoint-source pollution to the lake. However, more water-quality and biological information are needed to determine which pollution prevention strategies will be most cost effective.

OBJECTIVE: The objectives of this project are to (1) document the water quality and planktonic populations in the lake, (2) estimate phosphorus and sediment loading to the lake, (3) determine the historical water quality of the lake by examining lake sediments, and (4) construct hydrologic and phosphorus budgets for the lake.

APPROACH: Phosphorus and streamflow were monitored at two locations upstream of Geneva Lake and at the outlet from which loads of phosphorus to and from the lake were estimated. Nutrient concentrations, dissolved oxygen, water temperature, $\mathrm{pH}$, specific conductance, and phytoplankton and zooplankton populations were monitored at different frequencies and different locations to determine the "best" frequency and locations to describe changes in water quality in the lake. Nutrient and phosphorus budgets will be constructed for the lake. Sediment cores will be analyzed to estimate sedimentation rates and the historical water quality of the lake. Eutrophication models will be used to evaluate various nutrient load reduction scenarios and dynamic models will be used to help understand changes in the dissolved oxygen concentrations in the lake.

PROGRESS (July 2000 to June 2001): Lake sampling was reduced to sampling just at the deep hole in the West Basin. Lake data were compiled for publication in the report, "Water Resources Data-Wisconsin". A phosphorus budget was constructed for the lake. Nutrient load reduction scenarios were modeled for the lake using WILMS. A dynamic model was configured for the lake and used to estimate evaporation and examine changes in dissolved oxygen concentrations. Sediment cores were analyzed and the results were published.

PLANS (July 2001 to June 2002): Approximately monthly lake sampling at the deep hole in the West Bay will be continued. Lake data will be compiled and published in the report, "Water Resources Data-Wisconsin". A water-resources investigations report will be published describing the results of all components of the project.

\section{REPORTS:}

Elder, J.F, Robertson, D.M., and Garrison, P.J., 2000, Chemical composition of surficial deposits in Geneva Lake, Wisconsin. U.S. Geological Survey Fact Sheet 121-00, 4 p.

\section{COOPERATOR:}

Geneva Lake Environmental

Agency

\section{LOCATION: \\ Walworth County}

PROJECT CHIEF:

Dale M. Robertson

William J. Rose

PERIOD OF PROJECT: March 1997 to September 2001 


\section{DETERMINATION OF STREAMFLOW, PHOSPHORUS, AND SOLIDS LOADS AT THREE SITES ABOVE SINISSIPPI LAKE IN DODGE COUNTY, WI 17317}

\section{COOPERATOR: \\ Town of Hubbard}

\author{
LOCATION: \\ Central Dodge County
}

PROJECT CHIEF:

David J. Graczyk

PERIOD OF PROJECT:

October 1997 to September 2001
PROBLEM: Sinissippi Lake was formed in 1845 by construction of a dam on the Rock River south of Horicon Marsh. The watershed area for the shallow (average depth $4.5 \mathrm{ft}$.) 2,855-acre lake is about 511 square miles. The lake is hypereutrophic with phosphorus concentrations ranging from 200 to 400 micrograms per liter. Secchi depths during summer average about 0.2 meters. Local, state, and federal resource agencies are concerned with the quality of the Horicon Marsh area, including Sinissippi Lake. Basic data are lacking to define the sources and magnitude of streamflow, phosphorus, and solids entering Sinissippi Lake.

OBJECTIVE: The primary objective of the study is to determine streamflow, phosphorus, and suspended-solids loading at East Branch Rock River near Mayville, West Branch Rock River near Waupun, and Rock River at Horicon and Hustisford.

APPROACH: Streamflow, phosphorus and suspended-solids load monitoring will be done at East Branch Rock River near Mayville, West Branch Rock River near Waupun, and Rock River at Horicon and Hustisford. Stream gages, employing conventional stage-discharge rating techniques, and equipped with automatic water samplers will be installed at East Branch Rock River near Mayville and West Branch Rock River near Waupun. The Rock River at Horicon site will be equipped with an acoustic velocity meter (AVM) gage because flat gradients preclude conventional gaging there. Samples will be collected manually by a local observer at the Horicon site. Loads will be calculated using streamflow-concentration-integration techniques.

PROGRESS (July 2000 to June 2001): Monitoring sites were operated through the 2000 water year and continued into the 2001 water year (October-December). Annual total phosphorus load at the West Branch Rock River was $82,800 \mathrm{lb}$; at the East Branch Rock River it was $52,500 \mathrm{lb}$; at the Rock River at Horicon the load was $150,800 \mathrm{lb}$ and at the Rock River at Hustisford the annual total phosphorus load was $187,100 \mathrm{lb}$. The total-phosphorus loads in water year 2000 were $28,550 \mathrm{lb}, 38,200 \mathrm{lb}$, and $167,400 \mathrm{lb}$ less in water year 1999 at the West Branch, East Branch and the Rock River at Horicon, respectively. Suspended solids loads were 1,210 tons at the West Branch Rock River, 2,030 tons at the East Branch Rock River, 7,910 tons at the Rock River at Horicon and 15,400 tons at the Rock River at Hustisford. The suspended solids loads in water year 2000 were 3,250 tons less at the West Branch and East Branch of the Rock River as compared to water year 1999. At the Rock River at Horicon, the suspended solids load was 18,000 tons less in water year 2000 as compared to water year 1999. All streamflow and water-quality data were summarized and published in the annual report "Water Resources Data-Wisconsin, 2000". The monitoring sites were discontinued at the end of December 2000.

PLANS: Project is complete. 


\section{WESTERN LAKE MICHIGAN DRAINAGES \\ NATIONAL WATER-QUALITY ASSESSMENT (NAWQA), WI 17400}

PROBLEM: Growing populations throughout the United States have resulted in increased development and use of our water resources. As our water resources become stressed, decisions on how to effectively utilize and manage these resources will need to be made. These decisions must be based on accurate assessments of the quality of the water resource and the factors affecting its use.

OBJECTIVE: The long-term goals of the NAWQA project are to determine the water quality of the streams and aquifers in the Western Lake Michigan Drainages (WMIC), determine the presence or absence of any trends in the water quality, and provide an understanding of the link between natural and anthropogenic factors and observed water quality. Specific goals are (1) to determine the occurrence and spatial distribution of a broad array of water-quality constituents in ground and surface water and stream-bed sediments, (2) determine the occurrence of contaminants in selected target taxa, (3) evaluate the aquatic habitat and community structure of streams in the study unit, (4) assess the surface- to ground-water interaction and the effects of land use on base-flow water quality in selected stream reaches, (5) evaluate the sources and transport of selected hydrophilic compounds in agricultural settings, and (6) assess the influence of land use on shallow ground-water quality in selected land-use settings.

APPROACH: The foundation of the study approach is based upon identifying relatively homogeneous areas of specific land-use and environmental characteristics. Identification of these areas was accomplished by overlaying digital coverages of land use and various environmental variables using a geographic information system (GIS). Sampling sites completely contained in these relatively homogeneous areas (indicator sites) were incorporated into a nested design of surface-water, streambed sediment, and biological sampling. The sampling strategy consists of a retrospective analysis of available water-quality data (1991-1993), followed by a high (19931995) and then a low-phase (1996-2000) data-collection effort, followed by a data analyses and planning year (2001) and another highphase (2002-2004) data-collection effort. Monitoring of surfacewater trend sites is being conducted. These sites have been sampled monthly and augmented with event-related samples. A subset of these sites were extensively sampled for pesticides. Synoptic studies were conducted during high- and low-flow conditions to better delineate the sources of nutrients throughout the basins and describe the seasonal variability of these sources. Another synoptic study determined how representative the BFSs were of the entire WMIC drainage area. Other program components included an ecological survey (spring 1993) at 20 sites to evaluate the relation between community (fish and invertebrates), habitat structure, land-use practices, and environmental factors. Ground-water studies included a study-unit survey, a flow-path study and two land-use studies.
COOPERATOR:

U.S. Geological Survey, Reston, Virginia

LOCATIONS:

Upper peninsula of Michigan from the Menominee River basin in the west to the Fishdam River basin in the east; and the eastern portion of Wisconsin to include the Menominee, Oconto, Peshtigo, Fox-Wolf River basins discharging to Green Bay, and in Wisconsin that directly drain into Lake Michigan from the west which include the Manitowoc, Sheboygan, Milwaukee, Root, and Pike River basins.

\section{PROJECT CHIEF:}

Charles A. Peters

PERIOD OF PROJECT: December 1990-Continuing

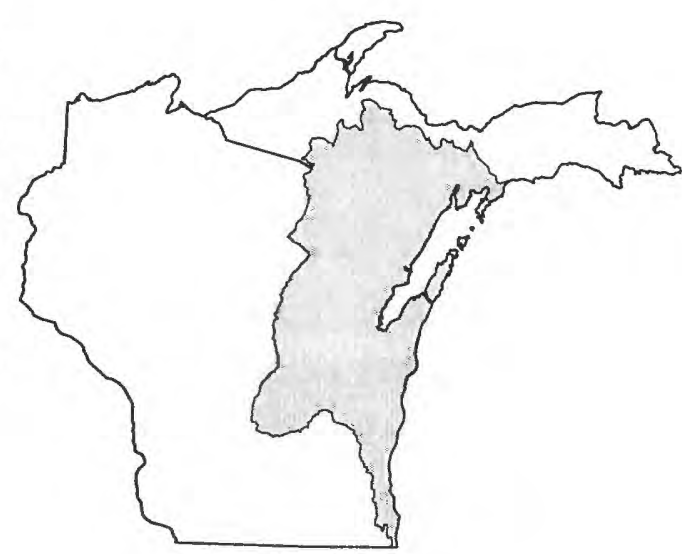


PROGRESS (July 2000 to June 2001): Two low-intensity phase (LIP) trend network sites were sampled monthly for discharge, field parameters, nutrients, pesticides, major ions, total and dissolved organic carbon, and suspended sediment. One of these sites was sampled for pesticides biweekly during the growing season.

Reports on basic fixed site algae, benchmark stream algae, and algal dynamics are being prepared.

PLANS (July 2001 to June 2002): Four surface-water trend network sites will be sampled monthly for discharge, field parameters, nutrients, major ions, total and dissolved organic carbon, and suspended sediment. The two sites will have ecological assessments for fish, algae and invertebrate population and habitat conducted. Bed sediment and tissue samples will be collected for trace element and organic analyses.

The ground-water study unit survey and one of the agriculture landuse studies will be revisited in 2003. A new major aquifer study (MAS) and urban land-use study are planned for 2004.

Data from the high-intensity phase, the low-intensity phase, as well as other data collected by other projects in the study area during the years 1991 to 2001 will be analyzed and the results of analyses compiled in reports. 


\section{UPPER ILLINOIS RIVER BASIN NATIONAL WATER-QUALITY ASSESSMENT (NAWQA), WI 17402}

PROBLEM: Growing populations throughout the United States have resulted in increased development and use of our water resources. As our water resources become stressed, decisions on how to effectively utilize and manage these resources will need to be made. These decisions must be based on accurate assessments of the quality of the water resource and the factors affecting its use.

OBJECTIVE: The long-term goals of the NAWQA project are to determine the water quality of the streams and aquifers in the Upper Illinois River Basin (UIRB), determine the presence or absence of any trends in the water quality, and provide an understanding of the link between natural and anthropogenic factors and observed water quality. Specific goals are to (1) determine the occurrence and spatial distribution of a broad array of water-quality constituents in ground and surface water and streambed sediments, (2) determine the occurrence of contaminants in selected target taxa, (3) evaluate the aquatic habitat and community structure of streams in the study unit, (4) assess the effects of urbanization on surfacewater quality in selected stream reaches, (5) evaluate the sources and transport of selected hydrophilic compounds in agricultural settings, and (6) assess the influence of land use on shallow ground-water quality in selected land-use settings.

APPROACH: The foundation of the study approach is based upon identifying relatively homogeneous areas of specific land-use and environmental characteristics. Identification of these areas was accomplished by overlaying digital coverages of land use and various environmental variables using a geographic information system (GIS). Sampling sites completely contained in these relatively homogeneous areas (irdicator sites) were incorporated into a nested design of surface-water, streambed sediment, and biological sampling. The sampling strategy consists of a retrospective analysis of available water-quality data (1997-1999), followed by a high (19992001) and then a low-phase (2002-2006) data-collection effort. Monitoring of basic fixed sites (BFS) in selected areas (indicator sites), as well as downstream sites draining heterogeneous land uses and environmental characteristics (integrator sites), are being conducted. These sites will be sampled monthly and augmented with event-related samples. A subset of these sites will be extensively sampled for pesticides and volatile organic compounds. Pesticide samples will be collected approximately biweekly during the early to mid-summer period and less frequently during the rest of the year. Volatile organic compound samples will be collected weekly during the winter and less frequently during the rest of the year. Other program components include an urban gradient study to evaluate the relation between community (fish, algae, and invertebrates), habitat structure, land-use practices, and environmental factors. Groundwater studies include: a study-unit survey and two land-use studies.

The land-use survey studies the effects of land use on ground-water quality through sampling in specific relatively homogeneous areas (1999 and 2000). A study unit survey provides an indication of water-quality conditions of the major aquifer (Silurian-Devonian) in the study unit.
COOPERATOR:

U.S. Geological Survey

Reston, Virginia

LOCATIONS:

Upper Illinois River Basin in

Illinois, Indiana, and Wisconsin

PROJECT CHIEF:

Kevin D. Richards

PERIOD OF PROJECT:

October 1996-Continuing

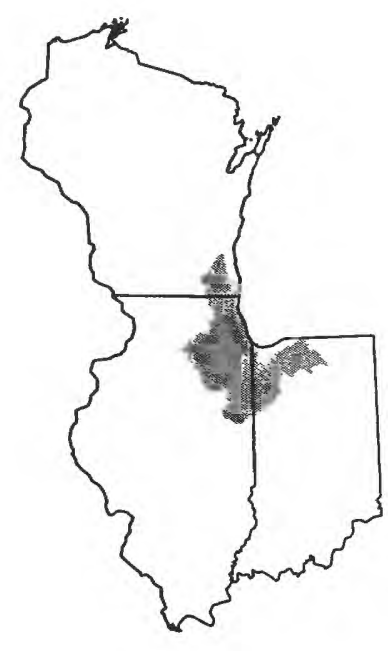


PROGRESS (July 2000 to June 2001): Water-quality and bed-sediment samples, habitat surveys and ecological assessment work was done at 46 sites in the Des Plaines and Fox River Basins as part of the urban land-use gradient study. All 46 sites were surveyed so bank-full capacity, stream slope, stream power and shear stress could be calculated.

The GIS coverages will continue to be compiled, including: labeling the clustered Landsat data, wetlands data from the WISCland inventory, Natural Resource Inventory, Toxic Release Inventory, etc.

Nine surface-water BFS were sampled monthly for discharge, field parameters, nutrients, major ions, and suspended sediment. Samples were collected for pesticide analyses frequently at three BFS.

PLANS (July 2001 to June 2002): Five surface-water BFS will be sampled monthly for discharge, field parameters, nutrients, major ions, total and dissolved organic carbon, and suspended sediment. Samples will be collected for pesticide analyses at three BFS. Two BFS will be discontinued in October 2001.

Multivariate analysis and modeling will begin on the land-use gradient data. Data will be compiled for one open-file report and analysis will continue on the gradient data. Two journal articles are planned for the gradient results.

Data from the high-intensity phase will continue to be analyzed and the results of analyses compiled in reports. Two water-resources investigations reports will be completed for distribution.

\section{REPORTS:}

Sullivan, Daniel J., 2000, Nutrients and suspended solids in surface waters of the Upper Illinois River Basin in Illinois, Indiana, and Wisconsin, 1978-97: U.S. Geological Survey Water-Resources Investigations Report 99-4275, 57 p. 


\section{TECHNICAL ASSISTANCE IN THE DEVELOPMENT OF REGIONAL NUTRIENT CRITERIA FOR THE NATION, WI 17406}

\begin{abstract}
PROBLEM: The U.S. Environmental Protection Agency (EPA) is required by the Clean Water Act to develop nutrient criteria for surface-water bodies of the United States. The proposed approach to define these criteria is based on an EPA ecoregion framework and the use of historical data assembled in STORET. Ecoregions are defined by relative differences in various environment characteristics. Because each environmental characteristic is not equally weighted in defining the ecoregions, the divisions among ecoregions are rather arbitrary and differences in water quality among ecoregions are difficult to attribute to any specific environmental factor. In addition, because the most important environmental characteristics used to define the ecoregion divisions may not be the primary factors affecting water quality, larger variations in water quality may occur within an ecoregion than among ecoregions. Therefore, there may be a more refined regional framework that could be used to define nutrient criteria than EPA ecoregions.
\end{abstract}

OBJECTIVE: The objectives of this study are to (1) determine the most statistically significant environmental characteristics affecting nutrient (phosphorus and nitrogen) concentrations over the Upper Midwest, (2) use regression-tree analyses and a geographical information system to delineate an alternate regionalization scheme for the study area, (3) describe the background concentrations and variability in these concentrations for each environmental nutrient zone within this new regionalization scheme, and (4) transfer results to EPA by participation on a Regional Technical Assistance Group.

APPROACH: The approach will be as follows: (1) assemble water-quality data from the USGS National Water-Quality Assessment (NAWQA) Program study units in the Upper Mississippi River Basin (UMRB), Illinois EPA, and Wisconsin Department of Natural Resources (WDNR); (2) determine the environmental characteristics of each basin, (3) use multivariate statistics (stepwise multiple regression and regression-tree analysis) to relate water-quality (total phosphorus and total nitrogen) and environmental characteristic data; (3) determine the relative importance of various environmental characteristics in affecting water quality and how they should be used to divide the Upper Midwest into relatively homogeneous water-quality regions; (4) describe the distribution of nutrient concentrations in each region; (5) define background concentrations for each region; and (6) compare resulting regional framework with the proposed EPA ecoregion approach.

PROGRESS (July 2000 to June 2001): All analyses were completed, an alternative regionalization scheme was developed, and a report was completed.

PLANS (July 2001 to June 2002): Participation on the Regional Technical Assistance Group will be continued and the new regionalization scheme will be published in a journal.

\section{REPORTS:}

Robertson, D.M., Saad, D.A., and Weiben, A.M., 2001, An alternative regionalization scheme for defining nutrient criteria for rivers and streams: U.S. Geological Survey Water-Resources Investigations Report 01-4073, $64 \mathrm{p}$.
COOPERATOR:

U.S. Environmental Protection

Agency

LOCATION:

Upper Midwest

PROJECT CHIEF:

Dale M. Robertson

PERIOD OF PROJECT: July 1999 to September 2001

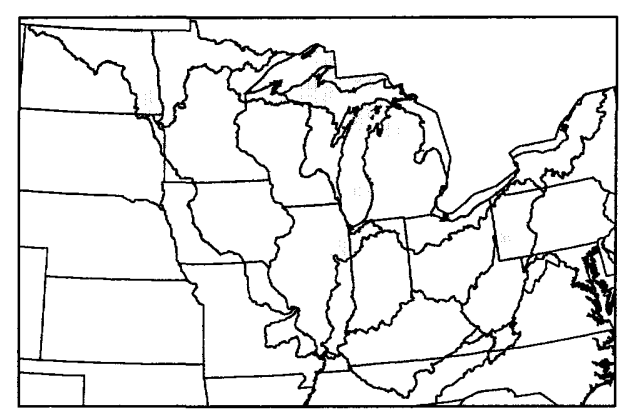




\section{HYDROLOGIC AND BIOGEOCHEMICAL BUDGETS IN TEMPERATE LAKES AND THEIR WATERSHEDS, NORTHERN WISCONSIN, WI 17500}

\author{
COOPERATOR: \\ Global Change Hydrology Pro- \\ gram, U.S. Geological Survey
}

\section{LOCATION:}

North-central Wisconsin

\author{
PROJECT CHIEFS: \\ John F. Walker \\ David P. Krabbenhoft \\ John F. Elder
}

PERIOD OF PROJECT:
October 1990-Continuing

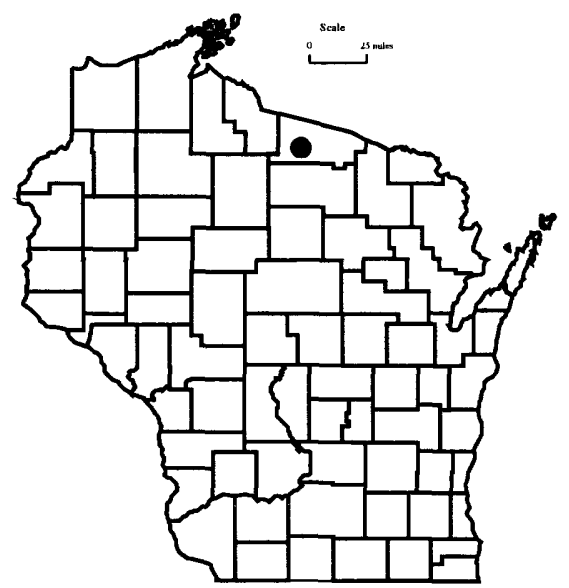

PROBLEM: There has been expanding evidence that rates of global changes are increasing. There is a need for research to identify, describe, and quantify the processes that control the Water, Energy, and Biogeochemical Budgets (WEBB) of aquatic ecosystems in order to understand and predict their responses to global changes. Promotion of such research is the function of the Water Resources Division's WEBB program. In the northern highlands lakes district of north-central Wisconsin, five lakes and two bog lakes have been the site of long-term ecological research conducted by University of Wisconsin scientists for the past decade. These studies have provided extensive information about biological and chemical features of the lake systems, but understanding of interactions among the lakes, streams, ground-water system, and wetlands is still limited. Research is urgently needed to describe these interactions and basinwide processes that influence the character of the lakes.

OBJECTIVE: Objectives are to (1) describe processes controlling water and solute fluxes in northern Wisconsin lake watersheds, (2) examine interactions among those processes and their relations to climatic variables, and (3) improve the capability to predict changes in water and solute fluxes for a range of spatial and temporal scales. Fulfillment of these objectives in Wisconsin will contribute to meeting the overall objective of the federal global change program - to understand processes underlying the responses of hydrologic, biologic, and chemical systems to climate variations and human activities.

APPROACH: Selected streamflow/recharge sites on tributaries of Trout Lake are the sites for detailed research of hydrologic processes. Most of the current research effort is concentrated at Allequash Creek, one of four inflowing tributaries of Trout Lake. Analyses of hydrologic connections among precipitation, streamflow, and ground water are conducted at three cross sections of the Allequash Creek basin. Monitoring and sampling equipment installed at these sites include piezometer nests, lysimeters, tensiometers, precipitation collectors, and thermocouple nests. Analyses of stable isotopes (C-13, O-18, Sr-86, and deuterium) are also used to determine water exchange pathways and sources of stream water. The site-specific hydrologic research is supported by data from several rain gages throughout the study area and a complete climatological station in the vicinity.

Stream- and ground-water samples, collected at each of the Trout Lake tributaries and at different points in the Allequash system, undergo analysis for nitrogen species, phosphorus, silica, organic carbon, major ions, and metals. Tributary sampling is done on a monthly basis, supplemented with more intense sampling of particular storms. Coupled with hydrologic data, the water sampling provides a basis for describing chemical budgets.

Investigation of geochemical processes that control transport of important chemical species across stream and lake sediments involves fine-scale sampling at the sediment/water interface. This is done by a variety of techniques, including membrane equilibrators, core squeezing, microprobes, and seepage meters. 
PROGRESS (July 2000 to June 2001): Ongoing data-collection efforts have continued. These include collecting samples at the streams tributary to Trout Lake, operating 5 continuous-record stream gages, monitoring water levels in a network of 22 wells, monitoring tension in 44 tensiometers, and collecting samples from 36 zerotension and 31 suction lysimeters. A publication investigating phosphorus dynamics in hydrologically distinct wetland systems and a publication discussing dissolved carbon mobilization in peatland systems are in press. Work continued on four new research efforts, including a comparison of solute budgets across the five WEBB sites, a unified approach to watershed modeling applied to the five WEBB sites, comparison of land-use history and sediment and carbon budgets across the five sites, and an investigation of macroinvertebrate populations and energy dynamics in the Allequash Creek system. Data and other information about the project are available on a World Wide Web home page (http://infotrek.er.usgs.gov/doc/webb/index.hmtl).

PLANS (July 2001 to June 2002): Basic data- collection efforts will continue, as well as data-collection efforts related to flow-path studies, carbon dynamics in the hyporheic zone, unsaturated zone processes, and macroinvertebrate dynamics. A variety of papers currently in preparation will likely be published, including one paper related to carbon chemistry and sources in Wisconsin streams, an overview of the flow paths and geochemical dynamics of Allequash Creek, a paper describing the ground-water-flow modeling along the isthmus between Crystal Lake and Big Muskellunge Lake, a paper describing the use of CFCs to trace ground water originating from lakes, and a paper describing the modular modeling effort.

\section{REPORTS:}

Elder, J.F., Goddard, G.L., and Homant, P.R., Phosphorus retention and yields in hydrologically different types of wetland systems in Wisconsin (USA), in Proceedings of Societas Internationalis Limnologiae, Dublin, Ireland (in press).

Elder, John F., Carter, Virginia, and Rybicki, N.B., 1998, Dissolved carbon mobilization in peatland/stream systems in northern Wisconsin (U.S.A.), Proceedings of V INTECOL Wetlands Symposium, Perth, Australia (in press).

Elder, J.F., Rybicki, N.B., Carter, V., and Weintraub, V., 2000 , Sources and yields of dissolved carbon in Northern Wisconsin stream catchments with differing amounts of peatland: WETLANDS, v. 20 , no. 1 , p. 113-125.

Walker, J.F. and Bullen, T.D., 1999, Trout Lake, Wisconsin: A water, energy and biogeochemical budgets program site, U.S. Geological Survey Fact Sheet 134-99, $4 \mathrm{p}$.
Hunt, R.J., Anderson, M.P., and Kelson, V.A., 1998, Improving a complex finite-difference ground water flow model through the use of an analytic element screening model: Ground Water, v. 36, no. 6, p. 10111017.

Hunt, R.J., Kelson, V.A., and Anderson, M.P., 1998, Linking an analytic element code to MODFLOW-Implementation and benefits, in MODFLOW 98: Proceedings of the 3 rd International Conference of the International Groundwater Modeling Center, Golden, Colorado, Colorado School of Mines, p. 497504.

Keating, E.H., and Bahr, J.M., 1998, Using reactive solutes to constrain groundwater flow models at a site in northern Wisconsin: Water Resources Research, v. 34, no. 12, p. 3561-3571.

Keating, E.H., and Bahr, J.M., 1998, Reactive transport modeling of redox geochemistry: Approaches to chemical disequilibrium and reaction rate estimation at a site in northern Wisconsin: Water Resources Research, v. 34 , no. 12 , p. 3573-3584.

Schindler, J.E., and Krabbenhoft, D.P., 1998, The hyporheic zone as a source of dissolved organic carbon and carbon gases to a temperate forested stream: Biogeochemistry, v. 43 , p. 157-174.

Walker, J.F., and Krabbenhoft, D.P., 1998, Groundwater and surface-water interactions in riparian and lakedominated systems, in McDonnell, J.J., and Kendall, C., eds., Isotope tracers in catchment hydrology: Amsterdam, The Netherlands, Elsevier, p. 467-488.

Bullen, Thomas D., Krabbenhoft, D.P., and Kendall, Carol, 1996, Kinetic and mineralogic controls on the evolution of groundwater chemistry and $87 \mathrm{Sr} / 86_{\mathrm{Sr}}$ in a sandy silicate aquifer, northern Wisconsin, U.S.A., Geochimica et Cosmochimica Acta, v. 60, no. 10, p. 1807-1821.

Krabbenhoft, D.P., Benoit, J.M., Babiarz, D.L., Hurley, J.P., and Andren, A.W., 1995, Mercury cycling in the Allequash Creek Watershed, northern Wisconsin, Water, Air, and Soil Pollution, v. 80, p. 425-433.

Keating, E.H., 1995, Reactive transport modelling: an application to redox geochemistry of groundwater discharging to a stream in northern Wisconsin, Ph.D. thesis, University of Wisconsin-Madison, Madison, Wisconsin, $216 \mathrm{p}$.

Krabbenhoft, D.P., Bowser, Carl J. Kendall, C., and Gat, J.R., 1994, Use of oxygen-18 and deuterium to assess the hydrology of groundwater-lake systems, in Environmental Chemistry of Lakes and Reservoirs (L.A. Baker, editor), American Chemical Society, p. 67-90.

Elder, John F., Krabbenhoft, David P., and Walker, John F., 1992, Water, Energy, and Biogeochemical Budgets (WEBB) program: data availability and research at the Northern Temperate Lakes site, Wisconsin: U.S. Geological Survey Open-File Report 92-48, 15 p. 


\section{ASSESSMENT OF THE HYDROLOGY, WATER QUALITY, AND BIOLOGY OF DELAVAN LAKE, WI 18101}

\section{COOPERATOR:}

Town of Delavan

\section{LOCATION: \\ Walworth County}

\author{
PROJECT CHIEF: \\ Gerald L. Goddard \\ Dale M. Robertson
}

PERIOD OF PROJECT: August 1983-Continuing

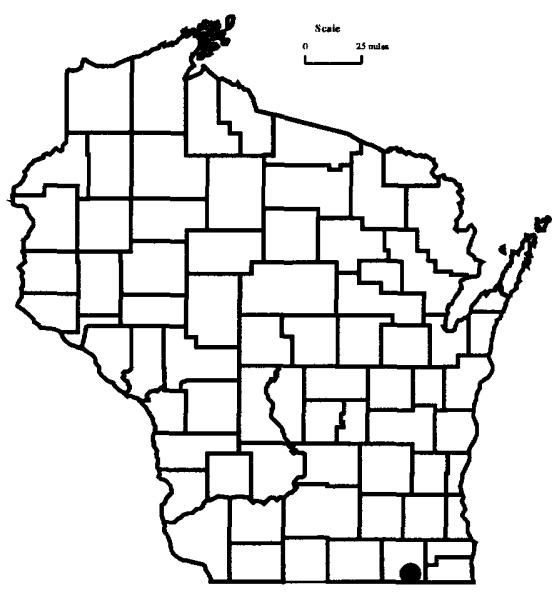

PROBLEM: Eutrophication of Delavan Lake has accelerated since the 1940s, resulting in a hypereutrophic lake with extensive blue-green algae blooms. Extensive rehabilitation efforts were implemented in 1990-1992 to improve the lake's water quality. Monitoring of the lake and nutrient and sediment loads to the lake is continuing to determine the effectiveness of the rehabilitation effort.

OBJECTIVE: The objectives are to: (1) quantify the effectiveness of rehabilitation efforts by measuring streamflow and nutrient and suspended-sediment loads at Jackson Creek tributary near Elkhorn, Jackson Creek at Mound Road (wetland outlet), Delavan Lake Inlet at Highway 50, and at the lake's outlet; (2) measure water quality, and plankton populations in the lake; and (3) determine the trapping efficiency of the wetland for phosphorus and suspended sediment.

APPROACH: Nutrients, suspended sediments, and streamflow are monitored at Jackson Creek tributary, the wetland outlet at Mound Road, at Highway 50, and the lake outlet. Nutrient concentrations, dissolved oxygen, water temperature, $\mathrm{pH}$, specific conductance, and planktonic populations are monitored within the lake. The effectiveness of the wetland is estimated by examining changes in the morphometry of the wetlands and changes in phosphorus and suspended sediment export at Mound Road.

PROGRESS (July 2000 to June 2001): Streamflow was monitored continuously at three inflow sites and at one outflow site. Water samples were collected monthly and during storm runoff events at all stream sites. Water samples were analyzed for nutrients and suspended sediment. The water quality at the center of the lake was monitored. The 2000 water-year data were compiled for publication in the report, "Water Resources Data-Wisconsin". A journal article describing changes in the lake from 1983-1998 was published. Lake phosphorus concentrations in 1996-2000 were similar to those prior to rehabilitation that was completed in 1993. Summer water clarity was greater and chlorophyll $a$ concentrations approached conditions similar to those prior to lake rehabilitation.

PLANS (July 2001 to June 2002): The monitoring program will be continued. Data will be compiled for publication.

\section{REPORTS:}

Robertson, D.M., Goddard, G.L., Helsel, D.R., and MacKinnon, K.L., 2000, Rehabilitation of Delavan Lake, Wisconsin: Lake and Reservoir Management, v. 20, no. 1.

Panuska, J.C., and Robertson, D.M., 1999, Estimating phosphorus concentrations following alum treatment using apparent settling velocities: Lakes and Reservoir Management, v. 15, no. 1, p. 28-38. 
Robertson, D.M., Elder, J.F., Goddard, G.L., and James, W.F., 1998, Dynamics in phosphorus retention in wetlands upstream of Delavan Lake, Wisconsin: Lakes and Reservoir Management, v. 14 , no. 4 , p. $466-477$.

Elder, J.F., Manion, B.J., and Goddard, G.L., 1997, Mesocosm experiments to assess factors affecting phosphorus retention and release in an extended Wisconsin wetland: USGS WaterResources Investigations Report 97-4272, 14 p.

Goddard, G.L., and Elder, J.F., 1997, Retention of sediments and nutrients in Jackson Creek Wetland near Delavan Lake, Wisconsin, 1993-95, USGS Water-Resources Investigations Report 97-4014, $22 \mathrm{p}$.

Elder, J.F. and Goddard, G.L., 1996, Sediment and nutrient trapping efficiency of a constructed wetland near Delavan Lake, Wisconsin, 1993-1995: U.S. Geological Survey Fact Sheet 232-96.

Robertson, D.M., Field, S.J, Elder, J.F., Goddard, G.L., and James, W.F., 1996, Phosphorus dynamics of Delavan Lake inlet in southeastern Wisconsin. U.S. Geological Survey WaterResources Investigations Report 96-4160, 18 p.

Field, Stephen J., and Duerk, Marvin D., 1988, Hydrology and water quality of Delavan Lake in southeastern Wisconsin: U.S. Geological Survey Water-Resources Investigations Report 874168, $61 \mathrm{p}$. 


\section{DANE COUNTY REGIONAL HYDROLOGIC STUDY, WI 18900}

\section{COOPERATORS:}

Wisconsin Geological and Natural History Survey

Dane County Regional Planning Commission

\section{LOCATION:}

Dane County

\section{PROJECT CHIEF:}

James T. Krohelski

PERIOD OF PROJECT: January 1992 - Continuing

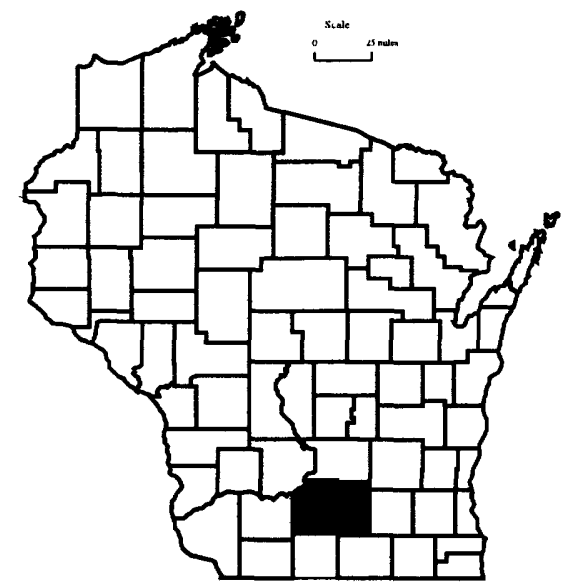

PROBLEM: Officials at all levels of government are concerned about the effects of increasing urban growth and development on the surface- and ground-water resources in Dane County. The relation between surface water and ground water must be understood to allow for increased ground-water withdrawals while protecting the quality and quantity of surface-water resources in the county. A comprehensive study that combines existing water data with new data is needed to provide government and planning agencies with a tool to aid in managing the water resources of the Dane County area.

OBJECTIVE: The objective is to improve the understanding of the ground-water system in relation to surface water and to provide a tool (ground-water-flow model) that will be useful in waterresource management decision making on a continuing basis.

APPROACH: The study is divided into three phases: (1) establish conceptual framework of the ground-water system and database, (2) develop and calibrate three-dimensional ground-waterflow model, and (3) determine how land-use and management strategies effect water resources.

PROGRESS (July 2000 to June 2001): The flow model was updated to explicitly include the Eau Claire confining unit. A new optimized calibration using the parameter estimation model UCODE was completed. Simulations incorporating potential landuse and management strategies were run and the results were given to the Dane County Regional Planning Commission.

PLANS (July 2001 to June 2002): Simulations incorporating potential land-use and management strategies will be run at the request of the Dane County Regional Planning Commission.

\section{REPORTS:}

Krohelski, J.T., Bradbury, K.R., Hunt, R.J., and Swanson, S.K., 2000, Numerical simulation of ground-water flow in Dane County, Wisconsin: Wisconsin Geological and Natural History Survey Bulletin 98, $31 \mathrm{p}$.

Bradbury, K.R., Swanson, S.C., Krohelski, J.T., and Fritz, A.K., 1997, Hydrogeology of Dane County, Wisconsin: Wisconsin Geological and Natural History Survey (in review). 


\section{TRANSPORT OF PCBS AT TWO SITES ON CEDAR CREEK, WI 19101}

PROBLEM: High concentrations of polychlorinated biphenyls (PCBs) have been found in the Cedar Creek bed sediments, water column, and fish tissues. Partial remediation of Cedar Creek (Ruck Impoundment) was completed in 1994. PCB transport trends are needed to assist in future management decisions.

OBJECTIVE: The objective is to determine PCB loading changes at Columbia Avenue (downstream of Ruck Impoundment) and Highland Road.

APPROACH: From August 1994 to August 1995, 24 PCB samples were collected at Columbia Avenue and Highland Road. Total suspended solids, chlorophyll $a$, and discharge data were used in conjunction with the PCB data to establish PCB concentration regression relations.

From December 2000 through October 2001, 24 more 80-liter PCB samples (along with supporting constituents) will be collected at the two Cedar Creek sites. Utilizing these data, residuals from the 19941995 regression relations will be examined to determine if PCB concentrations have statisically changed over time.

PROGRESS (July 2000 to June 2001): Field equipment blanks have been collected; equipment, cleaning and processing procedures have been found to be acceptable. Two winter baseflow sample rounds have been collected and sent to the State Laboratory of Hygiene.

PLANS (July 2001 to June 2002): The remaining 20 PCB samples along with accompanying constituents will be collected.
COOPERATOR:

Wisconsin Department of

Natural Resources

LOCATION:

Ozaukee County

PROJECT CHIEF:

Jeffrey J. Steuer

PERIOD OF PROJECT:

April 2000 to September 2001

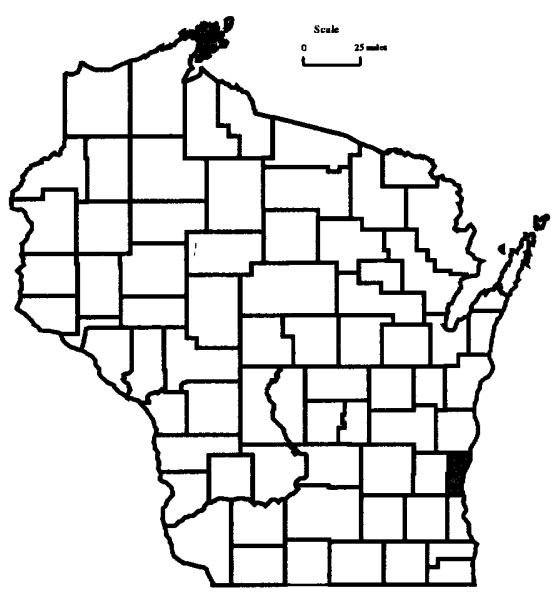




\section{FISH CREEK, WI 19300}

COOPERATOR:

Wisconsin Department of

Natural Resources

U.S. Fish and Wildlife Service

\section{LOCATION:}

Bayfield County

\section{PROJECT CHIEF: Faith Fitzpatrick}

\section{PERIOD OF PROJECT:} July 2000 to September 2003

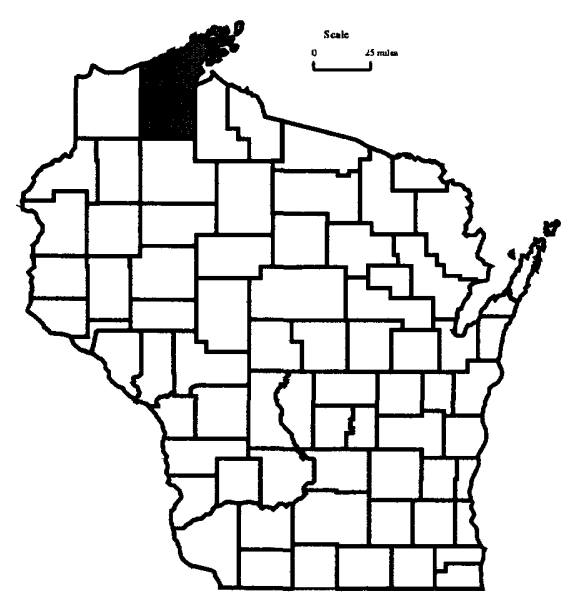

PROBLEM: A demonstration of the effectiveness of submerged vanes for reducing bank erosion and improving aquatic habitat at two sites is proposed for a site on North Fish Creek, a Wisconsin tributary to Chequamegon Bay, Lake Superior. Tributaries to Lake Superior are typically hard to access due to steep topography, lack of roads, and forested, swampy land. Techniques for stabilizing bluffs and reducing erosion for these types of streams need to be appropriate for remote areas and for minimal disturbance of the channel and spawning beds. Submerged vanes are cost-effective alternatives to traditional, bank structural measures or measures that would reduce flood peaks, such as detention basins. Submerged vanes are environmentally less intrusive because the bank is left in its natural state and are installed by hand. Submerged vanes have been used successfully in Wisconsin, Iowa and England.

OBJECTIVES: Objectives are to reduce erosion and subsequent sedimentation problems in North Fish Creek; demonstrate the ability of an instream restoration technique (submerged vanes on the channel bed) to reduce bluff erosion along a flashy, high-energy stream; improve the downstream quality of gravel spawning beds and reduce associated sedimentation problems; reduce amount of sediment transported downstream to Lake Superior; and share results with a variety of local, county, state and federal agencies in the form of formal and informal presentations and reports.

APPROACH: Submerged vanes (flat plates, height $\sim 0.3 \mathrm{x}$ water depth, length $\sim 3 \mathrm{x}$ height) will be installed in channel bed. The number, size, and layout of the vanes depend on the channel morphology, velocity, and depth at a meander bend. Typically, about 15 vanes are installed in groups of one to three. Vanes modify the secondary flows that cause erosion along the toe of a bank in a meander bend and stabilize a channel reach without inducing changes upstream or downstream of that reach.

The success of the study will be monitored through surveys of the bluff face, streamflow and channel conditions before, during and after installation of the submerged vanes. Bluff and channel surveys at several sites were completed by the USGS in 1995 . These sites will be resurveyed prior to installation of the vanes and yearly thereafter (or following floods) for two/three years following installation. The bluff and channel will be resurveyed after flood events. Channel cross-section surveys will be conducted at the site and in upstream and downstream locations to quantify changes in the shape and location of the channel. A streamflow-gaging station will be reactivated downstream of the site to properly quantify flood magnitudes experienced during the demonstration. Stage recorders will be installed at the bluff sites.

PROGRESS (July 2000 to June 2001):

BLUFF AND CHANNEL SURVEYS: Bluff and channel surveys were done prior to vane installation in April and August 2000. Based on aerial photographs, the bluff retreated approximately 10 meters 
from 1938-1990, or about 0.2 meters/year. Bluff retreat rates at the site were identified by measuring the distance from stakes placed in 1994 to the edge of the bluff face at seven locations. Average retreat rate from 1994 to 2000 for the bluff is 0.14 meters per year based on retreat of the bluff edge at the top of the bluff. Eight channel cross sections were completed by use of a total station and will be used to monitor the shape and condition of the channel following vane installation. Channel cross-section data also were used to define the layout for the vanes.

VANE INSTALLATION: Vanes were designed and installed in the summer and fall of 2000 . The vane layout includes 11 vane arrays (cross sections containing vanes) with 2 arrays upstream of the bend and bluff and 9 arrays through the entire bend. The vanes are made out of white high-density polyethylene (HDPE), are 3 feet long with heights equal to 0.3 (average bankfull depth at the section), and oriented at 20 degrees to local flow conditions in each section. The vanes were cut to the approximate size in the laboratory and were modified at the site. The approximate height of the vanes is 1 foot. The tops of the vanes are about 2 to 5 inches above the water level at low flow.

STREAMFLOW-GAGING STATION AND STAGE RECORDER: A streamflow-gaging station was reactivated on North Fish Creek near Moquah, Wisconsin, in June 2000. This gaging station is located approximately eight miles downstream of the vane installation site at the Bayfield/Ino location. Streamflow information will be used to help identify the flood conditions experienced after vane installation. A stage recorder was installed at the site in March 2001. The hourly stage data collected by the recorder will be used to identify peak flood stages encountered by the vanes.

PLANS (July 2001 to June 2002): The next year will involve writing up the results from the installation process and reviewing the surveying data from the transects. Cross sections that compare the original transects with transects after the vanes were installed and after major floods will be completed. A lab experiment will also be undertaken to investigate vane-flow interactions as a basis for improving vane geometry, orientation and layout. Cross sections will be resurveyed in spring 2002 following the runoff event related to snow-melt and following any floods related to summer storms. If possible, the cross sections will be surveyed before snowmelt (dependent on snow depth). The gaging station and stage recorder will be operated through September 2003. The location for the second vane installation site will be discussed with the Wisconsin DNR, Bayfield County, and the U.S. Fish and Wildlife Service. Vanes will be installed at the second site in the summer/fall of 2001. 


\section{FLORIDA EVERGLADES MERCURY CYCLING, WI 19700}

COOPERATOR:

U.S. Geological Survey

Reston, Virginia

LOCATION:

Florida Everglades

\section{PROJECT CHIEF:}

David P. Krabbenhoft

\section{PERIOD OF PROJECT: January 1995-Continuing}

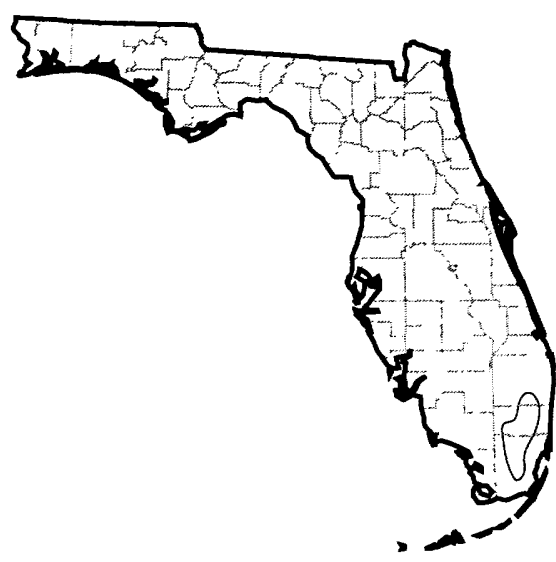

PROBLEM: Mercury contamination is one of the largest potential health risks to aquatic organisms, predatory animals, and humans. This great concern is the result of two observations: (1) mercury biomagnifies in the food chain to toxic concentrations even though it is found at very low aqueous concentrations and (2) the principal source to most areas is atmospheric deposition. Thus, almost any aquatic ecosystem with a food chain is potentially susceptible to mercury contamination.

OBJECTIVE: The overall objective of this project is to provide a better understanding of the mercury contamination problem in the Florida Everglades and other aquatic ecosystems. Specific processes will be investigated, including particle and dissolved transport, volatilization, methylation, and interactions with dissolved organic carbon.

APPROACH: A new direction and series of approaches is being implemented for the second phase of our mercury cycling research in the Everglades. Briefly, we are using wetland enclosures and stable isotope of mercury in a combined approach to address management questions in a more direct fashion than our previous studies could provide. For example, a series of replicate enclosures will have varying levels of mercury isotope added to the water column within them to simulate recent atmospheric mercury deposition. After the isotope addition, the rates at which the "new" mercury is methylated and incorporated into biota within the enclosures will be monitored. With this type of information, agencies responsible for directing Everglades restoration efforts can more reliably make decisions on what preventive actions can be taken with regard to mercury toxicity in the Everglades.

PROGRESS (July 2000 to June 2001): Sixty custom-made wetland enclosures were manufactured and installed at five sites in the northern and central Everglades. In May, three enclosures at each site had ${ }^{202} \mathrm{Hg}$ added, and a fourth enclosure had sulfur added (a limiting constituent for mercury methylation). A second experiment was conducted in September using ${ }^{200} \mathrm{Hg}$, which allowed for discriminating recently added mercury pools that differed in age by 4.5 months. Following the amendments, samples were collected three times over a seven-day period, and then again at six and eight weeks time. Samples are analyzed on the new Inductively Coupled Plasma Mass Spectrometer (ICPMS) that is operated by the Mercury Studies Team in the Wisconsin District Office.

PLANS (July 2001 to June 2002): Twice-annual field trips are conducted to repeat and expand the experimental approaches for the use of wetland enclosures and chemical additions to test the environmental response to the additions. Sample analysis and interpretations will be used to help guide each series of tests, in addition to asking other state and federal agencies for their input on questions we can possibly answer with these experiments. Results from the first two rounds of experiments using mercury isotopes suggest that the "new" mercury added to the enclosures is more available to accumulation in biota than the historic accumulation in the sediments of the Everglades. 


\section{MITIGATION OF FUTURE NORTH FORK URBANIZATION IMPACTS ON THE PHEASANT BRANCH HYDROLOGIC SYSTEM, WI 20200, 20203, 20204}

PROBLEM: As Middleton and its surroundings continue to develop, the Pheasant Branch North Fork Basin is expected to undergo significant urbanization. For the downstream city of Middleton, headwater urbanization can mean increased flood peaks, increased water volume and increased pollutant loads. It may also adversely effect down-gradient ecosystems such as Pheasant Branch Marsh and reduce ground-water recharge. Previous work has often not included the transient interaction between surface and ground water. The proposed work will combine ground- and surface-water modeling in the analysis of the Pheasant Branch system.

OBJECTIVE: Objectives are to (1) locate potential sites for runoff controls and/or enhanced infiltration to ensure future flood peaks do not exceed the present condition flood peaks, (2) quantify the flood peak and ground-water recharge differences resulting from a fully-urbanized condition with and without treatment or runoff controls, (3) use the ground-water model to assess North Fork basin urbanization impacts on Pheasant Branch Marsh, and (4) construct a ground-water model able to address future needs such as siting future water supply.

APPROACH: The overall approach will combine ground- and surface-water models to locate an effective combination of stormwater treatment or control sites within the North Fork basin which may be developed to produce minimal effects on the Pheasant Branch hydrologic system. The surface-water component will build upon the simulations detailed in "Effects of urbanization on streamflow, sediment loads, and channel morphology in Pheasant Branch Basin near Middleton, Wisconsin" (Krug and Goddard, 1985, WRIR 85-4068). To achieve the objectives of this project, the model will contain a spatial resolution to simulate 1 to 4 developments per square mile (approximately 40 model sub-areas). Significant development has occurred in the South Fork basin since 1981. Two of the areas simulated as not generating runoff in 1981 have developed and presently drain to the South Fork. It will be necessary to update the South Fork basin model to ensure that shifting of the North Fork hydrograph peak (due to runoff controls) will not produce an enhanced peak downstream of the confluence (Krug and Goddard, pages 16, 17). The new model efforts will calibrate to recently collected Pheasant Branch discharge and precipitation data collected at Highway 12 .

The ground-water component will use a model constructed at a smaller scale than the recently developed Dane County model (Krohelski, et.al., in press) to have the appropriate resolution for the stormwater control alternatives. Similar to Krohelski, et.al., the model will be constructed using MODFLOW (McDonald and Harbaugh, 1988). Recharge results from the surface-water model will be input into the ground-water-flow model to assess the effects of management alternatives on ground-water recharge distribution and magnitude. The model will also calculate the changes in groundwater-derived baseflow in the system for the different alternatives and assess the effectiveness of recharge enhancement scenarios.
COOPERATOR:

City of Middleton

Wisconsin Department of

Natural Resources

LOCATION:

Dane County

PROJECT CHIEFS:

Jeffrey J. Steuer

Randy Hunt

PERIOD OF PROJECT:

July 1996 to September 2002

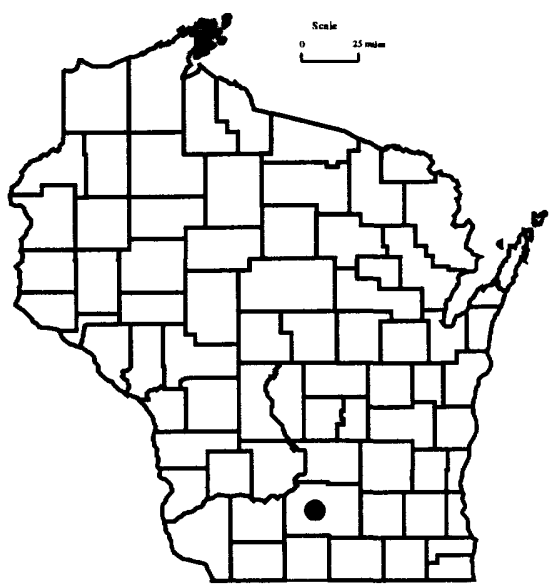


In February 2000, the project was expanded when the models were accepted as part of an Environmental Protection Agency (EPA)/National Science Foundation (NSF) research grant. The expanded research will be coordinated by the WDNR and UW-Madison. To further that effort, the surface-water model will be modified to incorporate research findings in local infiltration and temperature pollution. The ground-water model will be refined to include additional geologic data and hydrologic features near the Pheasant Branch Marsh. The refined model will then be used for optimization to further assess the effects of development on surface-water resources in the area.

PROGRESS (July 2000 to June 2001): The calibrated PRMS model was updated and verified for the period October 1998 through October 2000 - an interval which included the largest recorded peak flow on Pheasant Branch Creek. Recurrence interval hydrographs for the South Fork Channel were provided to a private consultant in support of the City of Middleton.

Measurements have been made in the Frederick Springs area to detail individual seepage areas along with several sites that extend downstream to Century Avenue. A flume has been installed downstream of the Frederick Springs area with data displayed on the World Wide Web.

The PRMS model has been nearly converted (90\%) to the Modular Modeling System to allow inclusion of local infiltration and head flux algorithms.

The surface water report "A Watershed Modeling Approach to Assessing the Hydrologic Effects of Urbanization in the North Fork Pheasant Branch Basin near Middleton, Wisconsin" is currently in review.

Assistance with geophysical logging of a monitoring well near the Springs was given to the Wisconsin Geological and Natural History Survey.

PLANS (July 2001 to June 2002): The conversion of the PRMS surface-water model to the Modular Modeling System will be completed and modules for the local infiltration and head flux algorithms will be written. The ground-water-flow model will be modified to include the insight gained from the new geochemical hydrologic data.

Support will be given to the larger Pheasant Branch project conducted by the Wisconsin Department of Natural Resources, the University of Wisconsin-Madison, and the Wisconsin Geological and Natural History Survey. The planned work includes well installation and instrumentation in a study subdivision and chemical and isotope analyses for water samples collected during the study.

\section{REPORTS:}

Hunt, R.J., and Steuer, J.J., 2000, Simulation of the recharge area for Frederick Springs, Dane County, Wisconsin: U.S. Geological Survey Water Resource Investigations Report 00-4172, 33 p.

Hunt, R.J., Steuer, J.J., Mansor, M.T.C., and Bullen, T.D., in press, Delineating a recharge area for a spring using numerical modeling, Monte Carlo techniques, and geochemical investigation. Ground Water. 


\section{MITIGATION OF FUTURE IMPACTS OF URBANIZATION ON THE BADGER MILL CREEK HYDROLOGIC SYSTEM, WI 20201}

PROBLEM: Urban development of the Badger Creek Watershed by the cities of Madison and Verona and the townships of Verona and Middleton will result in higher flood peaks and increased pollutant loading within the watershed. Mitigating these effects after urban development can be expensive and administratively difficult. To reduce costs and difficulties associated with land acquisition, the local governing bodies desire a proactive approach that will locate regional runoff treatment or control sites prior to development. To complete this assessment, hydrologic information needs to be collected to calibrate a surface-water model.

OBJECTIVE: The three objectives for this project are (1) collect streamflow and rainfall data at three sites within the Badger Mill Creek sub-watershed, (2) collect rainfall data at two additional sites within the basin, and (3) construct a surface-water model to assess the impacts of urbanization.

APPROACH: The study has two components. (1) Field component-three new USGS gaging stations will be installed in the Badger Mill Creek sub-watershed. Flow will be continuously monitored and rainfall data will be collected. Water-quality samples will be taken during event flows to measure total and suspended solids, total and dissolved phosphorus and selected metals. Two additional remote rain-gage stations will be installed throughout the basin to determine the spatial variability of rainfall. (2) Surface-water model component-a stormwater management model (SWMM) will be constructed and calibrated with field data collected by the USGS during the summer of 1997. The spatial resolution of the model will simulate approximately one to four developments per square mile. Rain-gage data will be used to estimate the spatial distribution of rainfall for the basin.

PROGRESS (July 2000 to June 2001): Water discharge records and water-quality data for the period of active record at Canterbury Road (054359315) and Nesbitt Road (0543934) were published in the annual report "Water Resources Data-Wisconsin".

PLANS (July 2001 to June 2002): Water discharge and rainfall will be measured and five water-quality events at Badger Mill Creek at Nesbitt Road will be sampled.
COOPERATOR:

City of Madison

LOCATION:

Dane County

PROJECT CHIEF: Judy Horwatich

PERIOD OF PROJECT:

October 1997 to September 2001

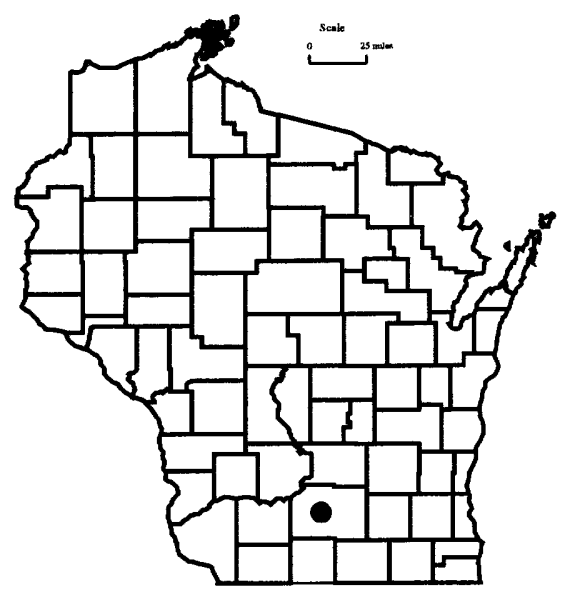




\section{MONITORING AND EVALUATION OF THE IMPACTS OF AIRCRAFT AND RUNWAY DEICERS ON THE KINNICKINNIC RIVER SURFACE-WATER RESOURCES, WI 20400}

COOPERATOR:

County of Milwaukee

\author{
LOCATION: \\ Milwaukee
}

PROJECT CHIEF:
Steven R. Corsi

PERIOD OF PROJECT: November 1996-Continuing

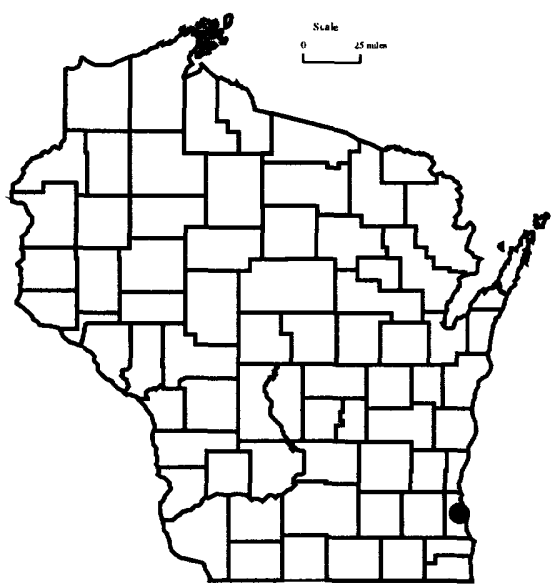

PROBLEM: Milwaukee County is involved in an effort to reduce runoff of deicing chemicals from General Mitchell International Airport (GMIA) to Wilson Park Creek. Ethylene and propylene glycol based deicers are used during cold weather periods to deice aircraft, runways, and other paved areas used by aircraft. Glycol concentrations in stream samples collected during deicing events throughout the winters between 1996 and 2000 ranged from less than detection limits to $39,000 \mathrm{mg} / \mathrm{L}$ in GMIA outfalls (well above toxicity limits).

OBJECTIVE: The overall goals of the project are to evaluate changes in water quality in Wilson Park Creek due to implementation of deicer management at GMIA and fulfill obligations stated in the Wisconsin Department of Natural Resources (WDNR) stormwater permit for GMIA. Specific objectives follow. (1) Monitor surface water at four sites in the Wilson Park Creek watershed for water quality and flow during dry weather and runoff conditions. This monitoring is to be conducted before and after implementation of deicer management. (2) Determine changes in water quality and toxicity levels in Wilson Park Creek due to implementation of deicer management. This monitoring should quantify a suite of water-quality parameters that are of interest as stated in the WPDES permit issued to GMIA by WDNR.

APPROACH: Flow is measured and samples are collected at one site upstream from airport runoff and four sites downstream. Assessments of water quality will be made on a yearly basis. After two years of post-management monitoring, comparisons between preand post-management data will be made to determine if changes in water quality have occurred.

PROGRESS (July 2000 to June 2001): An extensive runoff monitoring program has been in place since November 1996. The first two winters represent conditions before deicer management was implemented.The 1998-1999 winter represents data with partial deicer management. Nine sites were monitored the first year and four sites are currently being monitored. Flow, dissolved oxygen, water temperature and rainfall are being monitored continuously. Water-quality constituents are sampled selectively during deicer application events, baseflow, and one summer rainfall event per year. Glycol, biochemical oxygen demand, selected nutrients and selected metals analyses are being conducted. Microtox and bioassay analyses are being conducted for toxicity assessment. In situ fathead minnow assays were conducted upstream and downstream from airport runoff. Two journal articles were written summarizing the first two years of dissolved oxygen, water chemistry, and toxicity data. 
PLANS (July 2001 to June 2002): Two more years of monitoring are planned during a period of deicer management. After monitoring of post-implementation runoff, statistical analyses will be conducted to determine the effectiveness of the deicer management practice. A direct comparison of pre- to post-implementation data will be done using paired-watershed and upstream-downstream analyses between sites.

Two reports have been written and will be published in June 2001 . At least two more reports will be written-one discussing the effects of deicer additives on receiving streams and the other will be an analysis of the effectiveness of deicer management practices at GMIA 


\section{MODELING THE EFFECTS OF THE CRANDON MINE USING THE HSPF WATERSHED MODEL, WI 20500}

COOPERATOR:

U.S. Environmental Protection Agency

LOCATION:

Forest County

PROJECT CHIEF:

Jana Stewart

PERIOD OF PROJECT: January 1997 to September 2001
PROBLEM: The Nicolet Minerals Company has proposed construction of a zinc and copper mine near Crandon, Wisconsin. Before any operations can begin, an environmental impact assessment must be written and approved. At present, it is uncertain what specific effects the mine will have on the hydrology and water quality of the streams and lakes in the area.

OBJECTIVE: The objectives of this project are to (1) assemble hydrologic, meteorologic, and land-use information for the area near the proposed mine, (2) develop a watershed model for the Swamp Creek basin, and (3) use the model to determine what potential impacts the mine will have on the hydrology of Swamp Creek and nearby lakes.

APPROACH: Available hydrologic, meteorologic and land-use information will be obtained from the U.S. Geological Survey databases, the Nicolet Minerals Company, the Mole Lake Tribe, the Wisconsin state climatologist, the National Climatic Data Center, and the Wisconsin Department of Natural Resources. These data will be used to develop a watershed model for the Swamp Creek Basin using the Hydrologic Simulation Program Fortran (HSPF) watershed model. The model will be calibrated using a subset of data available for Swamp Creek and verified using an independent subset of the data. The model will be adjusted to simulate mine construction, operation, and closure. The output of the model will be used to quantify the effects of the mining operations on the water levels of streams and lakes in the area.

PROGRESS (July 2000 to June 2001): Hydrologic, meteorologic, and land-use information were assembled. Model calibration and verification were completed. Model scenarios are in progress and a report being written.

PLANS (July 2001 to September 2001): The calibrated HSPF model will be adjusted to quantify the effects of the mine construction, operation, and closure on the water levels of streams and lakes in the area. The report will be finalized and final GIS layers will be documented. Meetings will be conducted to present final results. 


\section{DEVELOPING A GEOGRAPHIC INFORMATION SYSTEM (GIS) DATA- BASE DEVELOPMENT AND SUPPORT OF MODFLOW AND HSPF MODELING EFFORTS RELATED TO THE PROPOSED CRANDON MINE, WI 20501}

PROBLEM: A number of modeling efforts are underway to evaluate potential changes to surface- and ground-water resources in the vicinity of the proposed Crandon mine. The United States Army Corps of Engineers (USACE) will be evaluating these potential effects using the MODFLOW model with modeling work and an environmental impact statement (EIS) being completed by third party contractors. The U.S. Environmental Protection Agency (USEPA) is working with the U.S. Geological Survey (USGS) and Aqua Terra Consultants, Inc., to develop a HSPF computer model for the simulation of the surface-water budget in the vicinity of the proposed mine. Although the objectives and scope of the two models differ, there is overlap between the areal extent of the models and the thematic data layers required for input, analysis, interpretation and evaluation. Data acquisition and development, GIS analyses and map displays prepared for one modeling effort need to be coordinated and shared for both modeling efforts and for impact assessment.

OBJECTIVE: The objectives of this project are to (1) coordinate GIS data acquisition and related communication in support of modeling and impact assessment, as directed by the U.S. Army Corp of Engineers (USACE), (2) conduct GIS analyses and provide displays related to the USACE third party MODFLOW modeling contractor effort, as needed and as directed by the USACE and USACEWaterways Experiment Station, and (3) review GIS analyses and displays related to third party Environmental Impact Statement contractor effort, as needed and directed by the USACE.

APPROACH: Spatial data layers will be acquired and developed as needed to assist in both surface- and ground-water modeling efforts and in support of impact assessment. Map figures and spatial data layers will be prepared using ARC/INFO and ArcView GIS software. Existing spatial data layers will be acquired from outside resources, including Wisconsin Department of Natural Resources, Great Lakes Indian Fish and Wildlife Commission, and Nicolet Minerals Company, if available. Other data layers will be developed and analyses conducted as needed.

PROGRESS (July 2000 to June 2001): The original scope of work for this project was rewritten as a result of the USACE FEMWATER modeling effort being dropped in place of a third party contractor MODFLOW modeling effort. Spatial data layers were acquired and map figures prepared as needed by the USACE, and the EIS contractors. A list of available data layers was prepared for the USACE and the EIS contractor.

PLANS (July 2001 to June 2002): Spatial data layers will be acquired, GIS analyses conducted, and map figures prepared, as needed by the USACE or the MODFLOW or EIS contractors. Review of GIS analyses and map figures will be conducted as requested by the USACE.
COOPERATOR:

U.S. Army Corps of Engineers

LOCATION:

Forest County

PROJECT CHIEF: Jana Stewart

PERIOD OF PROJECT:

October 1998 to September 2001

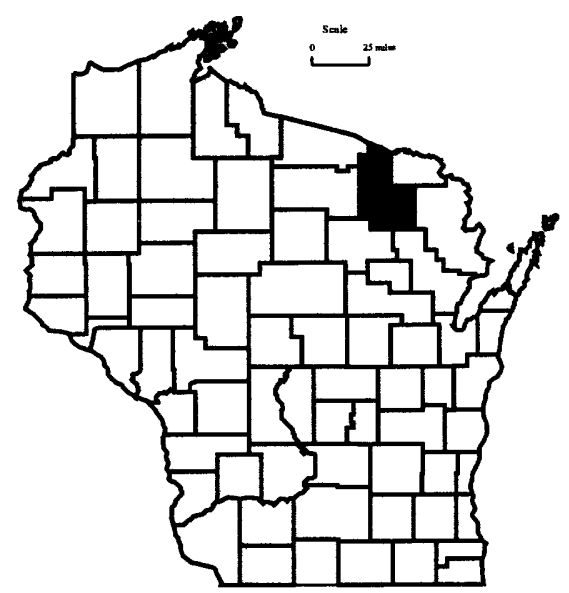




\section{SOUTHEAST WISCONSIN GROUND WATER, WI 20800}

\author{
COOPERATOR: \\ Wisconsin Geological and \\ Natural History Survey
}

\section{LOCATION:}

Southeastern Wisconsin

PROJECT CHIEF:

Daniel Feinstein

\section{PERIOD OF PROJECT: February 1998 to September 2003}

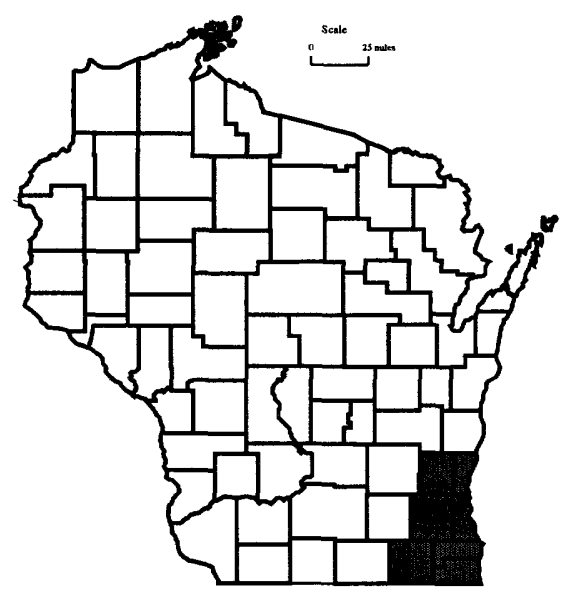

PROBLEM: Much public attention has been focused in the last several years on the problem of insuring an adequate and inexpensive supply of water to southeastern Wisconsin in the next century. The southeastern Wisconsin communities of Waukesha, Brookfield, Germantown, Menominee Falls and Pewaukee are prohibited by the Great Lakes Charter from drawing water from Lake Michigan. Water utilities in these areas are concerned that rapidly falling groundwater levels in the sandstone aquifer indicate that water supply will not be able to keep pace with development.

OBJECTIVE: In southeast Wisconsin there is a need to construct a three-dimensional ground-water model to address circulation within the shallow and deep aquifer systems in the presence of intense pumping for water supply. The overall aims of the project are to (1) determine essential hydrogeologic parameters of the regional aquifers to permit accurate simulation of regional flows and allow better understanding of the communication between shallow and deep systems; (2) investigate flow paths under different use scenarios for purposes of delineating capture zones and wellhead protection areas, evaluating well interference, and examining groundwater/surface-water connections; and (3) permit optimization of future well placement and pumping schedules by use of submodels.

APPROACH: The water utilities need information from the USGS to decide on a regional strategy for optimizing water supply. Specifically they need a framework to decide on the spacing, number, and, perhaps most critically, the open interval. A balance is needed between relatively thin shallow aquifers that are potentially subject to surface contamination and the underlying thick sandstone aquifer that suffers from excessive drawdown, increasing salinity, and potential radium influx. Optimization depends on many factors: for example, mapping of recharge areas to the shallow system and the sandstone aquifer, evaluation of the exchange between the two systems across units such as the Maquoketa Shale, and a better understanding of the stratigraphy in the deep sandstone aquifer. A regional three-dimensional model will serve as the platform for integrating these factors. It will also serve as the tool for simulating optimization scenarios.

PROGRESS (July 2000 to June 2001): The tasks performed this year were all directed toward construction of the regional model. Tasks included (1) final assembly of stratigraphic databases based on over 3,000 well logs that allow differentiation of fine and coarse zones in glacial and bedrock units; (2) final assembly of a stream network from GIS coverages that allow the stage and geometry of hundreds of rivers and lakes to be input to the model; (3) definition of key input arrays for the regional model such as recharge arrays and properties of bedrock valleys, as well as the hydraulic conductivity fields for all glacial carbonate and sandstone units; (4) collection of geophysical and flow meter data from deep wells to determine gradients between sandstone units; (5) final construction of a model simulating pre-development conditions; and (6) calibration of pre-development model to historical water-level data, spring locations and flux estimates. 
PLANS (July 2001 to June 2002): During the third year of the model, the tasks undertaken by the USGS will include (1) calibration of steady-state model to current stressed conditions, ( 2 calibration of transient model to historical trends, (3) preparation of a report on the construction and calibration of the model, (4) delineation of capture zones to define well-head protection zones for shallow and deep wells, and (5) development of management and optimization scenarios to guide location of future well fields. 


\section{SALTON SEA SCIENCE SUBCOMMITTEE, WI 20900}

COOPERATOR:

U.S. Geological Survey, Biological Resources Division

LOCATION:

Salton Sea, California

\section{PROJECT CHIEF:} John F. Elder

\section{PERIOD OF PROJECT: February 1998 to September 2001}

PROBLEM: Environmental conditions at the Salton Sea, a saline lake and important wildlife refuge in southern California, have been deteriorating for many years. Salinity has increased steadily and is now 25 percent higher than that of ocean water. Concentrations of other contaminants have also increased. Lacking any outlet tributary, the water levels and chemistry of the Sea are largely controlled by evaporation and the inflows from agricultural drainage. Major fish and wildlife kills have occurred in recent years. Very little research has been done previously to describe the ecology and environmental stresses of this unique ecosystem.

In late 1997, the Department of Interior initiated a Salton Sea Restoration Project. Following guidelines of the National Environmental Policy Act (NEPA) and the California Environmental Quality Act (CEQA), this project included funding of: (1) scientific research to produce more information about the system; (2) preparation of an environmental impact statement/report (EIS/EIR); and (3) assessment of various management alternatives (including no action). Leadership of the Restoration Project is shared by two agenciesU.S. Bureau of Reclamation and the Salton Sea Authority.

The role of the Wisconsin District in the Salton Sea Restoration Project has been to provide input to the consideration of issues by hydrology, water quality, and aquatic ecology relative to decisions about research and management needs at the Salton Sea. This input was provided in 1998-99 by representation on the Salton Sea Science Subcommittee, and has continued since then with oversight of research projects and cooperation with the Salton Sea Science Office which was established following the dissolution of the Subcommittee. The Wisconsin District hydrologist assigned to this project has had responsibilities for coordination of scientific research funded by the project, and liaison between research scientists and project managment. This work includes: (1) identification of research needs; (2) soliciting research proposals to fill those needs; and (3) coordination and oversight of the studies that were funded to fill those needs.

OBJECTIVES: The purpose of the Science Coordination component of the Salton Sea Restoration Project is to facilitate and coordinate scientific investigations yielding information critical to improved understanding of the ecosystem. This information and understanding provides a basis for making sound decisions to mitigate the current degradation of the Salton Sea ecosystem and to restore environmental, wildlife, recreational, and economic values.

APPROACH: The roles of the Wisconsin District personnel in Salton Sea activities include: serve as liaison between the Salton Sea Restoration Project and ongoing scientific research investigations; (2) serve as technical advisor and reviewing official for ongoing studies of limnology, water chemistry and sediment chemistry at the Salton Sea; (3) provide miscellaneous correspondence and technical advising tasks as needed by the Salton Sea Science Office;and (4) organize and coordinate workshops, symposia, technical meetings, and training sessions as needed to facilitate the flow of information pertinent to understanding and management of the Sea. 
PROGRESS (July 2000 to June 2001): Studies of nutrient cycling, avian diseases, fish population ecology, and biological limnology continued. A technical workshop on eutrophication was held in Riverside, California, in September 2000. Another workshop on salinity and salt precipitation was held in Riverside in January 2001. The workshops brought together experts in these topics to consider special problems at the Salton Sea and what management practices, if any, should be implemented to address them.

PLANS (July 2001 to September 2001): Liaison functions for projects in progress will be completed. Miscellaneous correspondence and technical advice will be provided as needed. The Wisconsin District role in the project terminates in September 2001. 


\section{DATABASE APPLICATIONS, WI 21000}

COOPERATOR:

City of Milwaukee

U.S. Environmental Protection

Agency (USEPA)

U.S. Geological Survey, CAPP and WRD

Wisconsin Department of Natural Resources (WDNR)

\section{LOCATION:}

United States

\section{PROJECT CHIEF:}

Harry House

\section{PERIOD OF PROJECT:}

July $1998-C o n t i n u i n g$
PROBLEM: Natural resources agencies are having difficulty organizing, storing, and distributing their information products using their existing resources (staff, hardware, and software).

OBJECTIVE: The purpose of this project is to provide our cooperators, the USGS, and other agencies with modern alternatives to their existing information technology resources. The objective is to provide our customers with access to high-quality data processing methods.

APPROACH: The Oracle Team in the Wisconsin District is dedicated to the design, development, and deployment of relational database systems geared to address water-resources-related data management problems being faced by our cooperators and other Federal agencies. Systems developed are centered on Oracle Corporation technology at this time. The focus is on fewer but larger projects in terms of workload and funding levels. The unit provides an alternative resource for these customers to compliment their inhouse information technology staff and/or outside consultants.

The Oracle Team applies cutting-edge technology in the resolution of the data mangement problems, within the limitations of available funding and staff. It is assumed that lower-end technology or approaches are more widely available to our customers already, and that we will provide a more valuable service by making higher-end solutions obtainable.

PROGRESS (July 2000 to June 2001): Twelve new servers were purchased to support the increasing resource demands of the unit. Support licensing was renewed for all software, and additional purchases of software for Oracle Internet Developer Suite, Oracle Internet Applications Server, and RDBMS were made. Data Junction and Infromatica were purchased to support data extraction, transformation, and loading activities.

The MWDI database system (subproject 21001) was dropped for lack of support from EPA after the contract ran out at the end of September 2000 .

The USGS Publications Warehouse (subproject 21002) became an official Gateway to the Earth sub-task. Agreement was reached to integrate the project with the GDA system in NMD. Data will be sourced from the USGS Library initially, but may come from GDA in the future. Multimedia data support is being incorporated into the system.

The EMPACT project (subproject 21003) with the City of Milwaukee ended in October 2000. However, the WDNR has indicated strong likelihood of renewing support for the site. In that event, the City and the WDNR will likely provide direction for requirements going forward. 
A new load of data was done for the NAWQA Data Warehouse (subproject 21004), and a planning database was created. A public interface was created, which was extremely popular.

The National Environmental Methods database (subproject 21006) has successfully passed prototype testing with the NEMI board. Additional methods are scheduled to be loaded by the end of the spring. A production deployment of mid-summer is expected.

The WDNR biological database (subproject 21005) went into production on January 1,2001 . There were numerous changes required to the system by the users, which have for the most part been implemented. Additional forms and possible server model redesign is anticipated in the near future.

PLANS (July 2001 to June 2002): It is expected that there will be additional purchases of servers to further enhance our hardware infrastructure. Expanded licensing levels will be pursued for existing and additional Oracle software products. It is likely the level of hardware/software resources required is beginning to reach acceptable levels, and it is expected that most of the costs for software in the next period will be for support renewal as opposed to new software licenses. Hardware also is approaching an acceptable level (approximately 20 servers) and we may see limited replacement of weaker servers with more powerful ones, as opposed to simply adding new servers to the mix in the future.

Is is anticipated that all current projects will be refunded in the next period and, in some cases, expanded. The level of funding supplied by these current projects is likely to tie up most of the personnel resources available in the team, so acquisition of new projects will be limited. We are still pursuing international work via the Office of International Hydrology as well as several other projects locally and nationally. We are targeting data needs that are not being presently addressed or looking for opportunities to deploy cutting-edge technology where appropriate.

Subproject 21002: We plan to go into production sometime this summer with national publication citation information. In addition, we will create a multi-media database storage and deployment system associated with the data warehouse. The goal is to have the site act as the central repository for WRD for that type of information.

Subproject 21003: If refunded, we plan to migrate the existing system to Oracle Portal and replace most of the custom programs with tool-based systems for the web interface. In addition, new forms and other features will probably be incorporated as requested by the City of Milwaukee and the WDNR.

Subproject 21004: A prototype mapping application, which displays query output on to a map should be in progress. More streamlined data loading methods are expected using the Infromatica tool. The planning database will be in production. We may add a module which supports an Oracle Portal for the National NAWQA website.

Subproject 21005: Additional forms will be created and deployed. A fish propagation module will be added. Initial support for a limited amount of water-quality data associated with biology samples will be incorporated. A system to bulk load data collected with GIS units will be investigated and may be deployed.

Subproject 21006: Production sometime in the summer of 2001 is anticipated. Additional methods will be loaded, and new method types will be made available for loading. The server model may need to be redesigned to accommodate expected changes in requirement. The web interface will be further refined in response to user requirements and new technologies. 


\section{WISCONSIN DEPARTMENT OF NATURAL RESOURCES BIOLOGY DATABASE, WI 21005}

\author{
COOPERATOR: \\ Wisconsin Department of Natural \\ Resources
}

\section{LOCATION:}

Statewide

\section{PROJECT CHIEF: David Hall}

\section{PERIOD OF PROJECT: January 2000 - Continuing}

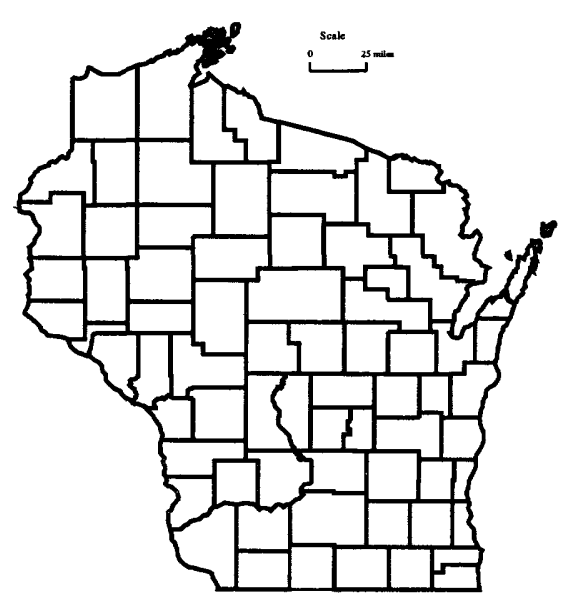

PROBLEM: The Wisconsin DNR Bureau of Fisheries Management and Habitat Protection collects and manages a wide variety of biological data. Data from biological programs were previously managed and stored in a number of different locations in a variety of formats, making retrieval and analysis of data from the different programs difficult and time-consuming.

OBJECTIVE: A single database was needed to unify data from five legacy databases and two new databases. The legacy databases are the Wisconsin Inland Fisheries (Paradox) Database, Wisconsin Fisheries Historical Database, Treaty Database, Master Fish File Database, and the Macro-invertebrate Database. The two new databases that were incorporated into the project include the Habitat Database and the Fish Propagation Database.

APPROACH: Initial development of the project was directed toward providing data-entry capability on the Internet for data from all major field activities. Six of the most widely used field forms for fish, habitat, and macroinvertebrate data were selected for deployment. Additionally, a minimal data-reporting requirement was specified for the first phase of production so that all data entered into the database could be retrieved by electronic reports over the Internet and saved as Excel or ASCII files. The database was deployed over the Internet so that geographically-dispersed users in 43 WDNR field offices could input and access data using electronic forms and reports.

PROGRESS: The first phase of the database was deployed on the Internet on schedule on January 1, 2001. The URL for the database website is: http://infotrek.er.usgs.gov/pls/WDNR BIOLOGY WDB/WDNR BIOLOGY WDB.home. Data-input forms provided data-entry capability for the six major field forms, and data could be saved in an Excel format. WDNR bioligists attended training during January 2001 in Madison. Substantial enhancements were quickly made to the database forms and reports in response to user comments. By February 15, 2001, the six forms selected for the first phase of production featured additional security, user correction and deletion of data, data-fill features that eliminated repetitive data entry, and specialized forms customized for rapid entry of large amounts of field data from tagging, biomass, and length-frequency surveys. Additionally, users have the ability to add or delete data for their data records at any time. Early in 2001, plans were finalized to incorporate most features of the WDNR Fish Propagation Program into the database. Plans for the propagation component of the database include data-capture and reporting for processes from stockingquota development, hatchery production, egg and fish transport, and final stocking. 
PLANS (July 2001 to June 2002): A major redesign of all database forms and reports will be implemented to provide for linking of data records by comprehensive survey dates in addition to discrete sampling dates and times. A variety of new forms and reports are scheduled for deployment. Data-input forms and reports will be generated for the Master Fish File legacy database, and approximately 23,000 legacy records from the Master Fish File will be loaded and made available for retrieval. Additional data from other legacy databases will be loaded as quickly as data can be properly formatted and prepared. Plans for the propagation component of the database include data-capture and reporting for processes from stocking-quota development, hatchery production, egg and fish transport, and final stocking. All database servers are scheduled for a major upgrade to provide faster form and report retrieval and a more stable environment. A feasibility study may be conducted to assess the utility of Trimble and Symbol units and electronic field data-entry forms as a paperless field data-collection system to produce data that are suitable for batch loading into the Biology database. 
WOLF RIVER SEDIMENT, WI 21100

COOPERATOR:

Menominee Indian Tribe of Wisconsin

LOCATION:

Menominee Indian Reservation

PROJECT CHIEF:

Faith A. Fitzpatrick

PERIOD OF PROJECT:

October 1998 to September 2001
PROBLEM: Protection of the pristine quality of the Wolf River in northeastern Wisconsin is of primary importance to the Menominee Indian Tribe of Wisconsin. Long-term historical data on streamflow, sedimentation rates, and trace element concentrations in sediment are needed to place current and future water-quality conditions as modified by human activity in perspective with natural conditions.

OBJECTIVE: The objectives are to (1) identify natural and historical concentrations of trace elements in streambed, floodplain, and backwater sediments of the Wolf River from Keshena Falls to Balsam Row Dam; (2) identify range of historical (150+ years) variability of flooding and sedimentation characteristics along the same reach of the Wolf River; (3) identify major factors affecting stream sedimentation and flooding characteristics-geologic/natural vs. land-use effects; and (4) investigate possibility of expanding study on the Wolf River upstream of Keshena Falls or on selected tributaries to the Wolf River.

APPROACH: Two long-term streamflow records will be examined for changes in peak flows (magnitude and frequency) and seasonality of flows on the Wolf River-Wolf River at Keshena Falls and Wolf River near Shawano. These streamflow records will be compared with the streamflow records from the Langlade gaging station. Government Land Office Survey notes will be examined and compared to current conditions at section line crossings. Thickness, texture, and stratigraphy of sediment in cores from the floodplain, backwater areas, and modern channel will be examined. Approximately six cores will be collected from approximately eight transects surveyed along the study reach. Selected core samples (approximately 24 samples) for particle size, trace elements, and radiometric dating will be sent to U.S. Geological Survey laboratories.

PROGRESS (July 2000 to June 2001): Writing of the water-resources investigations report was started.

PLANS (July 2001 to June 2002): Water-resources investigations report titled "Historical trends in streamflow, sedimentation rates, and sediment trace-element concentrations associated with the Wolf River, Keshena Falls to Balsam Row Dam" will be completed and published. 


\section{NEOPIT MILL POND SEDIMENTATION AND SEDIMENT CHEMISTRY STUDY, WI 21101}

PROBLEM: The dam at the Neopit Mill Pond, Neopit, Wisconsin, Menominee Reservation, may be removed. The Menominee Tribe needs information on the volume, texture, and chemistry of sediment stored behind the dam. The pre-dam channel of the West Branch Wolf River is not known. This information is needed for sound decision-making involving the dam removal and subsequent stream restoration.

OBJECTIVE: The project objectives are to (1) establish predam topography and volume of sediment in the Mill Pond; (2) define the texture, and organic and trace element chemistry of the post-dam sediment in the Neopit Mill Pond; and (3) identify the pre-dam channel of the West Branch of the Wolf River.

APPROACH: Water depth and soft sediment depth will be measured by use of sounding poles at approximately 13 cross sections. Land surveys of banks and islands bisected by cross sections will be conducted. The USGS will provide training for personnel from Environmental Services, Menominee Tribe, to conduct the soundings. Approximately one to three cores will be collected per cross section with a piston corer and geoprobe. Selected cores will be subsampled for analysis of particle size, 137Cs dating, water content, trace elements, and organic contaminants. Samples will be submitted to the USGS National Water-Quality Laboratory for analyses of trace elements, organic contaminants, and $137 \mathrm{Cs}$ dating. Particle size samples will be submitted to the USGS particle size laboratory in Iowa. Water content will be measured at the USGS in Middleton, Wiscon$\sin$. Approximately 10 percent of the samples will be submitted for quality assurance. Results will be published as a USGS open-file or water-resources investigations report.

PROGRESS (February 2001 to June 2001): Approximately 11 cores were collected with a piston corer and geoprobe over ice in Februrary 2001. Cores were vertically extruded on site and subsampled. Samples were frozen for archive. The USGS provided training for Menominee Tribe personnel to conduct the soundings in June 2001. A subset of samples was submitted for laboratory analysis in May 2001.

PLANS (July 2001 to June 2002): The remaining samples will be submitted for laboratory analyses in July 2001. Sounding work will be completed by September 2001. Data analysis and report writing will begin in October 2001.
COOPERATOR:

Menominee Indian Tribe of
Wisconsin

\section{LOCATION:}

Neopit

PROJECT CHIEF:

Faith Fitzpatrick

PERIOD OF PROJECT:

February 2001 to September 2002

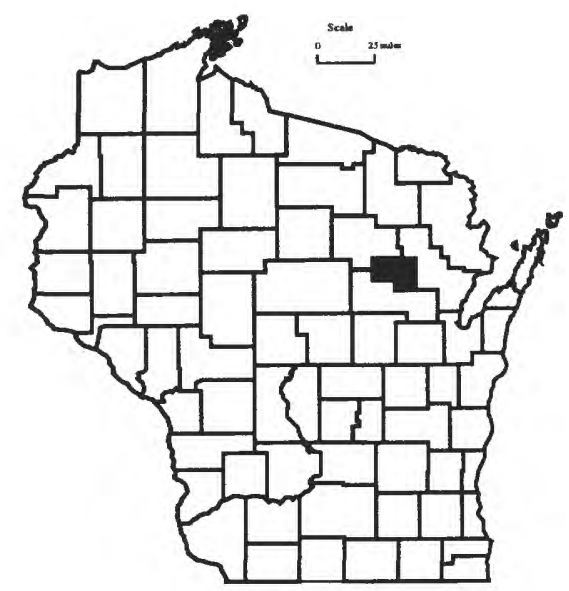




\section{ST. CROIX NATIONAL SCENIC RIVERWAY-NUTRIENT AND SEDIMENT LOADING AND LONG-TERM WATER-QUALITY MONITORING, WI 21202, 00301}

\author{
COOPERATOR: \\ National Park Service \\ Joint Water Quality Commission \\ of Danbury and St. Croix \\ Chippewa Indians of Wisconsin
}

LOCATION:

St. Croix National Scenic

Riverway

PROJECT CHIEF:

Bernard N. Lenz

PERIOD OF PROJECT:

October 1998 to September 2001

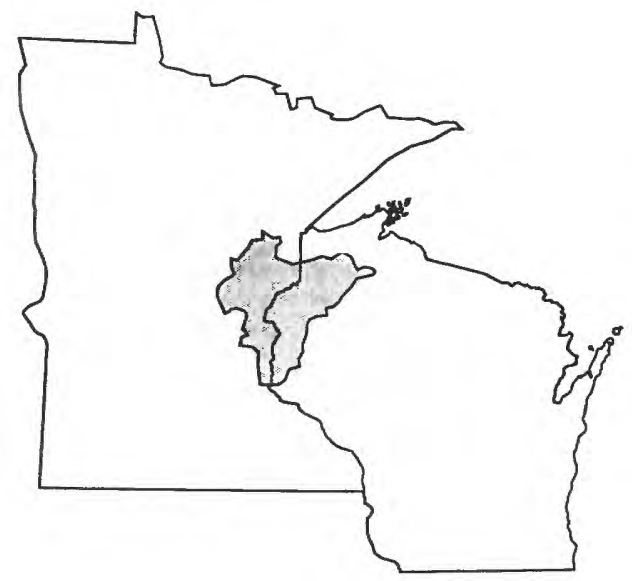

PROBLEM: The St. Croix National Scenic Riverway (NSR) contains more than 60 state and federally listed endangered and threatened species, indicating that it provides one of the few remaining relatively well-preserved and biologically diverse aquatic environments in the region. The Riverway has a very active management and scientific community and a rich research history. Although the water quality is generally considered to be good in the upper St. Croix and Namekagon Rivers, activities in the tributaries and their watershed are affecting the overall health of the St. Croix NSR. In the Lower St. Croix, including Lake St. Croix, nutrient levels are elevated. Recreational and developmental pressures are intensifying in the watershed. Recreational use has doubled since 1973 to nearly one million visitors yearly. Due to its proximity to the Minneapolis/St. Paul metropolitan area, the Riverway will continue to experience increased use and developmental pressure from population growth in the counties adjacent to the Riverway.

OBJECTIVE: The objective is to provide consistent, long-term water-quality monitoring at key sites on the St. Croix River to develop a long-term database to use to detect changes and protect the water resources of the St. Croix River.

APPROACH: 21200-USGS/Joint Water Quality Commission of Danbury and St. Croix Chippewa Indians of Wisconsin-From October 2000 through September 2001, the USGS continuously monitors streamflow, and collects sediment and nutrient samples at the St. Croix River near Danbury. Historical long-term USGS waterquality data from the St. Croix River at Danbury will be summarized and compared to recent water-quality data and be presented in a fact sheet in 2002.

21202-USGS/NPS Long-Term Monitoring-The USGS has developed a cooperative agreement with the NPS to continuously monitor streamflow at the Namekagon River near Leonards. Additionally, the project funds collection of samples for nutrients, sediments, major ions, and organic carbon at the St. Croix River at St. Croix Falls.

PROGRESS (July 2000 to June 2001): Continuous streamflow monitoring and monthly water-quality sampling were completed at the main-stem sites. Snowmelt runoff and a spring storm event have been sampled. Semiannual progress reports are being supplied to the NPS throughout the project. Many new partnerships with scientists and agencies working in the St. Croix Basin have been developed. A heightened awareness of nutrient and sediment loading and these new relationships should lead to continued scientific interest and study in the St. Croix Scenic Riverway.

PLANS (July 2001 to September 2000): Water-quality sampling and continuous-flow monitoring will continue. A fact sheet will be written in 2002. This fact sheet will relate historical longterm water quality and flow to recent water quality and flows. 


\section{ST. CROIX NATIONAL SCENIC RIVERWAY-NUTRIENT AND SEDIMENT LOADING, WATER-QUALITY MONITORING AND ASSESSMENT PARTNERSHIP, WI 21300}

\begin{abstract}
PROBLEM: The St. Croix National Scenic Riverway (NSR) contains more than 60 state and federally listed endangered and threatened species, indicating that it provides one of the few remaining relatively well-preserved and biologically diverse aquatic environments in the region. The Riverway has a very active management and scientific community and a rich research history. Although the water quality is generally considered to be good in the upper St. Croix and Namekagon Rivers, activities in the tributaries and their watershed are affecting the overall health of the St. Croix NSR. In the Lower St. Croix, including Lake St. Croix, nutrient levels are elevated. Recreational and developmental pressures are intensifying in the watershed. Recreational use has doubled since 1973 to nearly one million visitors yearly. Due to its proximity to the Minneapolis/St. Paul metropolitan area, the Riverway will continue to experience increased use and developmental pressure from population growth in the counties adjacent to the Riverway.
\end{abstract}

OBJECTIVE: Objectives are to (1) examine existing data to determine areas of significant sediment and nutrient contributions in the St. Croix River Basin; (2) collect nutrient, sediment, and flow data from tributaries that are significant contributors or have specific land-use or environmental factors thought to be related to sediment and nutrient yields; (3) determine relations of environmental factors and land use to sediment and nutrient yields in the St. Croix River Basin; (4) predict sediment and nutrient yields in the unmonitored portion of the basin using known land use and environmental factors and their relations to sediment and nutrient yields determined in this study to estimate nutrient and sediment budgets for the entire St. Croix River Basin; and (5) provide model inputs for a FLUX BATHTUB model of Lake St. Croix and the St. Croix Reservoir at St. Croix Falls.

APPROACH: Sediment, nutrient and flow data were collected at tributaries to the St. Croix River and annual loads were calculated using the USGS loads calculation program ESTIMATOR. Point source loading data was obtained. Annual yields were calculated by dividing annual loads by basin drainage area. Environmental factors such as land use, soils, and geology were derived for monitored and unmonitored tributary subbasin from existing GIS coverages and databases. The multivariate statistical procedures were used to determine environmental factors with the most significant relation to nonpoint-source sediment and nutrient yields in the monitored portions of the basin. Multivariate regressions between yields and environmental factors were developed and used to estimate loads in the unmonitored portions of the basin. Errors of estimation were included. The calculated tributary loads, estimated tributary loads and calculated loads data from the main-stem sites provide a temporally consistent snapshot of nutrient and sediment loading in the St. Croix River watershed. Water-resource managers and park officials can use the results of this study to plan, study, implement, or protect water resources in the St. Croix Basin.
COOPERATOR:

National Park Service

LOCATION:

St. Croix National Scenic Riverway

PROJECT CHIEF:

Bernard N. Lenz

PERIOD OF PROJECT:

October 1998 to September 2000

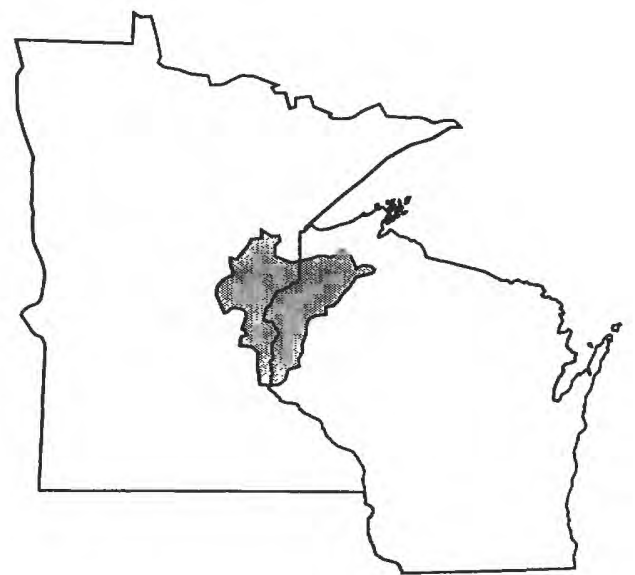


PROGRESS (July 2000 to June 2001): Continuous-flow monitoring and water-quality sampling were completed and loads calculated at USGS monitored sites. Additionally, MPCA has data similar to the USGS data at sites above St. Croix Falls (Kettle, Snake, and Sunrise River). Loads were calculated from this data as well. Environmental factors such as soils, land use/land cover, and geology has been determined by tributary sub-basin from existing GIS coverages. Semiannual progress reports have been supplied to the Park Service.

The MPCA, WDNR, and Metropolitan Council Environment Services contributed additional money and/or time to sample Lake St. Croix and the Indianhead Reservoir above the St. Croix Falls power plant during the 1999 water year. A BATHTUB model will be used to look at the nutrient and sediment in these impoundments. USGS tributary data is an essential part of this model's inputs.

A water-resources investigation report is being published. This report gives calculated sediment and nutrient loads on the monitored tributaries and main-stem sites. It discusses relations between environmental factors and loads and these relations are used to estimate nutrient loads on the unmonitored tributaries. Estimated sediment and nutrient loading by tributary for the entire St. Croix River basin is presented in the report. The multiagency correspondence and meetings will continue in order to coordinate the projects, share ideas, and disseminate results.

PLANS: Project is complete. 


\section{WHITTLESEY CREEK HYDROLOGY STUDY, WI 21500}

PROBLEM: Whittlesey Creek is considered an Outstanding Resource Water and Valued Lake Superior Ecosystem Member. This small watershed serves as spawning ground for 35 percent of Wisconsin's coho salmon population because of its consistent base flow and good water quality. However, like many Wisconsin tributaries to Lake Superior, aquatic habitat in Whittlesey Creek is possibly degraded because of accelerated runoff and associated sedimentation problems. In addition, the sources for the abundant baseflow in Whittlesey Creek are not very well understood. Recently, the mouth of Whittlesey Creek has been proposed as a National refuge for the re-establishment of Coaster Brook Trout. A hydrologic analysis of streamflow in Whittlesey Creek is needed to identify potential present and future land-cover impacts on baseflow and flooding characteristics of the creek.

OBJECTIVE: Objectives are to (1) quantify current streamflow characteristics for Whittlesey Creek floods, base flow, and seasonal fluctuations, (2) quantify contributions of runoff and ground water to streamflow, (3) identify ground-water recharge and discharge areas for Whittlesey Creek (identify contributions from glacial deposits vs. sandstone bedrock aquifers), (4) identify pre-settlement hydrologic conditions, (5) quantify how current land-cover characteristics affect flood and base-flow characteristics, (6) predict how future changes in land cover affect floods and base flow in Whittlesey Creek and (7) identify areas of the basin that contribute the most to flooding problems.

APPROACH: This approach uses an event-based rainfall/runoff model (HEC-1; U.S. Army Corps of Engineers, 1990) and a USGS ground-water model (MODFLOW; McDonald and Harbaugh, 1998) to quantify base flow and flooding characteristics of Whittlesey Creek. Hydrologic field data also will be collected to help refine and calibrate the models. The proposed study would start in April 1999 with installation and operation of a streamflow and rainfall gaging station near the mouth of Whittlesey Creek and a survey of baseflow conditions (seepage run). In FY 2000, additional field data would be collected for the rainfall/runoff and ground-water models, GIS data for the rainfall/runoff model will be gathered, and the models will be run and calibrated. In FY 2001, a report on the modeling results will be written and published

PROGRESS (July 2000 to June 2001): Base-flow survey was conducted in August 2000, gaging station and stage recorders were maintained and ground-water and rainfall/runoff models were updated.

PLANS (July 2001 to June 2002): Rainfall/runoff model will be completed. Streamflow-gaging station will be continued. Report will be written.

\section{COOPERATOR:}

Bayfield County

LOCATION:

Bayfield County

\section{PROJECT CHIEF:}

Faith Fitzpatrick

PERIOD OF PROJECT:

May 1999 to September 2001

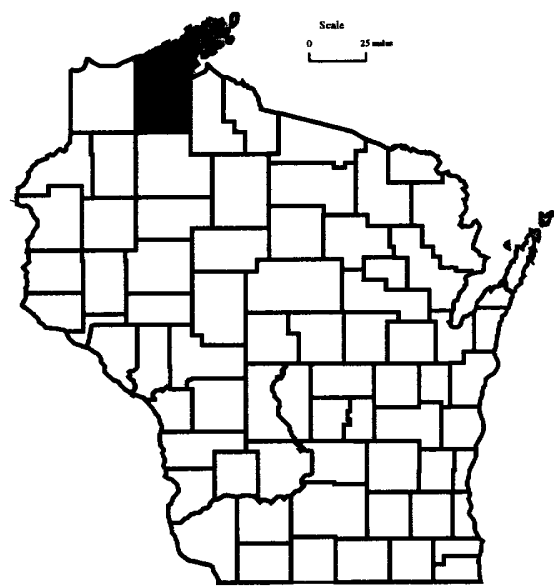




\section{SOURCES OF CRYPTOSPORIDIUM IN WATERSHEDS, WI 21600}

\author{
COOPERATOR: \\ Wisconsin State Laboratory of \\ Hygiene
}

\section{LOCATION:}

Southeast Wisconsin

\author{
PROJECT CHIEF: \\ Steve Corsi \\ Robert Waschbusch
}

\section{PERIOD OF PROJECT: October 1999 to April 2002}

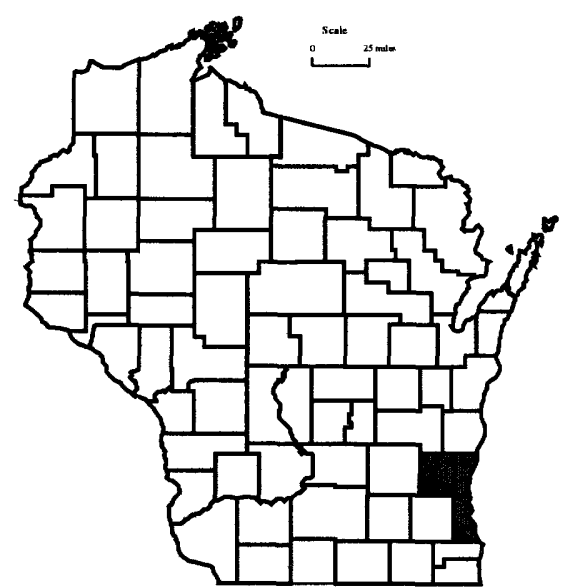

PROBLEM: For the past 75 years, the water supply industry has enjoyed an excellent track record of providing safe, potable water to the public. As a result, the industry has achieved a high level of consumer confidence in tap water. This success has been possible through an emphasis on continuous improvement in both watertreatment technology and source-water protection. Despite this effort, recent well-publicized waterborne disease outbreaks of cryptosporidiosis involving large numbers of ill people and some deaths have been attributed to possible treatment deficiencies linked with source-water contamination. Recent studies have suggested that the Milwaukee outbreak of 1993 was caused by a "human only" genotype which would point to poorly treated human waste as a possible source of the outbreak. It is extremely important that both the wastewater industry and the drinking water industry have the best information available to respond to both water-borne disease issues and legislative issues in an effective manner. Understanding the occurrence and variability of cryptosporidium in source water is critical to the production of a safe drinking water supply. Essential to this understanding is the ability to characterize potential sources of cryptosporidium and predict their response to hydrologic and climatologic events.

OBJECTIVE: The goals of the research outlined in this proposal are to define the relative magnitude and contributions of cryptosporidium from major sources defined by land use and wastewater discharges on an annual basis, to characterize contributions of each source by factors such as hydrograph timing, climatic effects, and seasonal variations, and to compare and integrate the resulting data with existing data on cryptosporidium.

APPROACH: Two subwatersheds were selected for monitoring the entire project duration.One of these basins is primarily agricultural land use and the other is primarily urban land use. In addition to these two subwatersheds, three wastewater treatment plant discharges representing different treatment technologies and/or flow levels and one combined sewer overflow (CSO) will be monitored for approximately six months each. Both fixed interval and weather event samples will be collected from all sites. The sample results will be used to determine cryptosporidium magnitude and variability. These data will be used along with flow data to calculate event and annual loads at the sites. Other data will also be collected including precipitation, water temperature, dissolved oxygen, turbidity, conductance and also land-use data in a GIS system. The data and tools resulting from this project will enable managers to better understand and deal with the sources of cryptosporidium in their watersheds.

PROGRESS (July 2000 to June 2001): The agricultural and urban basins and three publicly-owned treatment works (POTW) have been selected and instrumented. Samples have been collected from runoff events and fixed intervals at all 3 types of sites for 20 months. 
PLANS (July 2001 to June 2002): Runoff event sampling and fixed interval sampling will continue through December 2001 at the agricultural and urban sites. One more event sample will be collected at the third POTW site and then the equipment will be moved to a CSO in Milwaukee. 


\section{HISTORICAL ECOSYSTEM RECONSTRUCTION AND POTENTIAL IDENTIFICATION OF EFFECTS OF PAST ECOSYSTEM PERTURBATIONS IN LAC COURTE OREILLES, WI 21700}

COOPERATOR:

Lac Courte Oreilles Tribe

\section{LOCATION:}

Lac Courte Oreilles Reservation, Sawyer County

\section{PROJECT CHIEF:}

Faith Fitzpatrick

PERIOD OF PROJECT:

October 1999 to September 2001
PROBLEM: There has been a potential increase in nutrient inputs and enhanced eutrophication in Musky Bay, Lac Courte Oreilles, Wisconsin in the last few decades. Historically, the Bay contained wild rice beds and was a major spawning ground for muskellunge, which make up a large portion of the Lac Courte Oreilles Tribe's diet. Currently, there are no wild rice beds in the Bay, organic muck covers the muskellunge spawning beds, and the bay is choked with macrophytes and algae. The Lac Courte Oreilles Tribe is interested in determining changes in historical nutrient inputs to Musky Bay, determining the source of the nutrients, and comparing these findings to historical nutrient inputs in other parts of Lac Courte Oreilles.

OBJECTIVE: The main objective is to reconstruct the ecosystem history of Musky Bay and an additional site within Lac Courte Oreilles with special emphasis on possible effects of cranberry farming and shoreline development using the sediment record. The principal focus is on the nutrient history (input and burial rates) that reflects management practices and possible watershed degradation. The modeled nutrient history will be interpreted in concert with reconstructed algal (mainly diatoms) communities preserved in the sediments. Another focus is to search for possible cranberry farming signatures including sulfur, uranium, and potassium associated with fertilizers, and copper associated with pesticides. Biogenic silica profiles will provide complimentary data for algal community reconstructions. The sediment record likely preserves observable trends in nutrient biogeochemical cycling and ecosystem character over the last few hundred years, a time that includes a background period and the period of cranberry farming.

APPROACH: Several cores from Musky Bay and additional sites on the lake will be collected in the fall or winter of 1999/2000. Dates and sedimentation rates will be calculated for 20 increments in the Musky Bay core ( 15 increments from an additional core) from analyses of ${ }^{210} \mathrm{~Pb},{ }^{226} \mathrm{Ra}$, and ${ }^{137} \mathrm{Cs}$ using direct gamma counting (Schelske et al., 1994). Total organic carbon and nutrient (nitrogen, phosphorus, biogenic silica) input and burial rates will be calculated from dated sediment by combining measured concentrations of these nutrients and mass sediment accumulation rates. Biogenic silica profiles will be used as supporting evidence for diatom reconstructions and as an indicator of species shifts (largely from diatoms to non-siliceous algae) in response to increased nutrient inputs. Diatom assemblages will be examined for 20 increments in the Musky Bay core (15 increments from the additional core). Plant macrofossils will be examined to directly reconstruct changes in wild rice beds to supplement littoral community changes suggested by the diatom assemblage. Macrofossils will be identified. Forty-two geochemical parameters will also be measured in these cores using inductively coupled plasma-mass spectrometry (ICP-MS). Bulk density and porosity of samples will be determined to adequately measure sedimentation rates and mass accumulation rates. A waterresources investigations report will be completed by September 2001 . 
PROGRESS (July 2000 to June 2001): All samples were analyzed.

PLANS (July 2001 to June 2002): Report will be written to present results of the project. 


\section{THE EFFECT OF NEAR-SHORE DEVELOPMENT ON CONSTITUENT LOADING TO LAKES IN NORTHERN WISCONSIN, WI 21800}

COOPERATOR:

Wisconsin Department of

Natural Resources

LOCATION:

Vilas and Forest Counties

PROJECT CHIEFS:

David J. Graczyk

Randall J. Hunt

PERIOD OF PROJECT:

October 1999 to September 2001
PROBLEM: Additions of nutrients, pesticides and sediment from near-shore developments to lakes may seriously degrade lake water quality. Shoreline-zoning regulations such as required setbacks, cutting restrictions and buffers between the lake and development have been developed in the hope that these requirements can mitigate the effects of sediment and nutrient runoff.

Previous studies have estimated the amount of these loadings from the lake watershed but few studies have determined the processes and pathways in which these constituents are delivered to the lake at a site-specific scale (e.g., one-acre parcel). The effectiveness of buffers or cutting restrictions on reducing the amount of chemical constituent loads and sediment has yet to be demonstrated.

OBJECTIVE: The objectives of the study are to (1) estimate the quantity of surface-water runoff and ground water that flows into a lake from developed and undeveloped lands and (2) determine the quality of surface-water runoff and ground water that flows into a lake from developed and undeveloped lands.

APPROACH: Effects of shoreline development on water and nutrient loading will be assessed using a paired approach. The comparison will focus on developed and undeveloped sites on four lakes in Vilas and Forest Counties in northern Wisconsin. Developed sites may include runoff from lawns, driveways, sidewalks and roofs; undeveloped sites consist of mostly immature woods having woody and non-woody vegetation and relatively undisturbed ground. Both surface-water runoff and ground-water components will be characterized where appropriate.

Sites were divided into those where the lakes have ground-water inflow and those that do not. Those that had ground-water inflow will be instrumented to characterize the ground- and surface-water components. Sites with ground-water flow away from the lake will be instrumented to characterize surface-water components only. Each site will be surveyed and a detailed map will be prepared to determine the areas that contribute to surface runoff.

A tipping bucket rain gage will be installed at each site. Precipitation will be measured during the non-freezing portion of the year. Precipitation from a nearby National Weather Service gage will be used during freezing periods.

Surface-water runoff will be measured by using two types of monitors depending on the site. An automatic collection monitor will be installed at four sites. A passive collection monitor will be installed at two sites. The quality of surface water will be determined from analyses of the runoff collected by both automated and non-automated systems. 
Ground-water flow will be monitored by the installation of piezometer nests. The nests will be distributed along the topographic gradient. The most down-gradient nest will be installed adjacent to the lakeshore. The quality of ground water will be determined from a subset of water table wells and piezometers located at the nest sites. In addition, the quality of ground water that discharges to the lake will be characterized using seepage meters and pore-water diffusion equilibrators.

All surface- and ground-water samples will be analyzed for total dissolved phosphorus, total phosphorus, ammonia nitrogen, nitrate and nitrite nitrogen and total Kjeldahl nitrogen. Approximately 7 surface-water samples per site will be collected and 5-10 ground-water samples will be collected. The Wisconsin State Laboratory of Hygiene will analyze all samples.

PROGRESS (July 2000 to June 2001): Sites were selected for study and five automated surface-water runoff data-collection sites were installed. These sites include three lawn and two woodland uses. Non-automated samplers at five woods and one lawn site were installed. Five ground-water data-collection systems were installed. Five tipping-bucket rain gages were also installed. Seven surface-water samples were collected. A detailed topographic map was prepared for each site.

PLANS (July 2001 to June 2002): Samples will be collected and analyzed at selected ground-water wells. Samples will be collected and analyzed at the surface-water data-collection sites. Seepage meters and pore-water equilibrators will be installed and waterquality samples will be collected. All water-quality data will be summarized and published in the annual report "Water Resources DataWisconsin, 2001". 


\section{REGIONAL HYDROGEOLOGIC STUDY OF LA CROSSE COUNTY, WI 21900}

COOPERATOR:

Wisconsin Department of

Natural Resources

LOCATION:

LaCrosse County

PROJECT CHIEF:

Randy Hunt

PERIOD OF PROJECT: July 2000 to October 2002

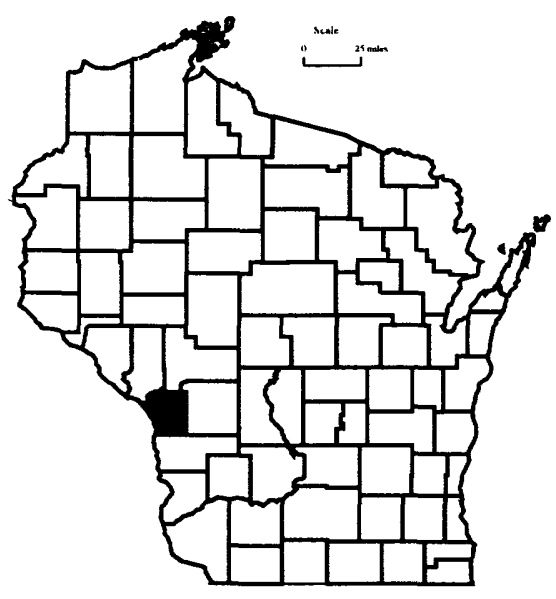

PROBLEM: Ground water is the sole source of residential water supply in LaCrosse County. Away from river valleys and the major population centers, bedrock aquifers are used for water supply. Approximately 75 percent of the residents are served by municipal water systems located along the Mississippi or Black Rivers (e.g., La Crosse, Onalaska, West Salem), which withdraw ground water from an alluvial aquifer. The alluvial aquifer is susceptible to contamination because of its proximity to the surface and lack of an areally extensive protective confining unit. Presently, there are over 120 ground-water contamination sites in LaCrosse County, mostly in the vicinity of the cities of LaCrosse and Onalaska. Knowledge of the regional ground-water system is needed in order to understand the sources of ground water for both the bedrock and alluvial fill aquifers.

OBJECTIVE: The purpose of the study is to understand and characterize the regional ground-water-flow system, as well as the local water resources around population centers. Specific objectives are as follows: collect, compile and analyze data to characterize the regional ground-water-flow system and form a conceptual hydrogeologic model; quantitatively identify the zone of contribution for each municipal ground-water supply system in the county using numerical modeling techniques; and encourage water-resource management and protection by introducing and promoting the use of study products through educational and outreach efforts in LaCrosse County.

APPROACH: Existing information regarding the spatial distribution and hydraulic properties of hydrogeologic units and wateruse data will be compiled. A database will be constructed so that data are accessible to staff working on the study as well as staff from interested state and local agencies. A three-dimensional model will be developed based on conceptual and initial analytic element screening models. Additional field data will be collected in areas requiring better definition or resolution of hydraulic parameters or to provide more complete coverage of water levels or stream flows. The model will be calibrated by comparing simulated ground-water levels and streamflows to measured. Zone of contributions for the 68 municipal supply wells within the county will be delineated using particle tracking and selected management scenarios will be simulated.

PROGRESS (July 2000 to June 2001): An analytic element ground-water-flow model of the regional system has been constructed. The model was calibrated using existing head and flux data from the area. Water-use data collection and synthesis has been started.

PLANS (July 2001 to June 2002): Existing data collection and database construction will be completed. The regional screening model will be refined to reflect the conceptual model developed during data collection. 


\section{REGIONAL HYDROGEOLOGIC STUDY OF SAUK COUNTY, WISCONSIN, W! 22000}

PROBLEM: Sauk County is under increasing development pressure, particularly in the Lake Delton/Wisconsin Dells area. Local development patterns have given rise to concerns about ground-water quality and quantity. As a result, county planners and officials recognize the increased need for knowledge of regional hydrologic conditions in order to make informed water-resource and land-use planning decisions. The purpose of this project is to conduct a comprehensive study of Sauk County's hydrogeologic resources and to delineate the zones of contribution (ZOC) for municipal wells located in the county. This project has been designed to meet the data needs of source-water protection efforts in Sauk County, and to provide technical and educational resources to promote source-water protection initiatives.

OBJECTIVE: The purpose of the Sauk County ground-water study is to understand and document the regional ground-water flow system, as well as the local hydrologic systems around population centers, so that water resources may be managed and preserved. The specific objectives are to (1) collect, compile and analyze data to characterize the regional ground-water-flow system and form a conceptual hydrogeologic model; (2) quantitatively identify the zone of contribution for each municipal ground-water supply system in the county using numerical modeling techniques; and (3) encourage water-resources management and protection by introducing and promoting the use of the study products through educational and outreach efforts in Sauk County

APPROACH: The project plan involves three phases of work.

Phase 1 - Characterization of Regional Hydrogeology

Existing information will be compiled regarding the spatial distribution and hydraulic properties of hydrogeologic units; water table and potentiometric surface maps of the significant aquifer units will be constructed; a model code for a regional screening level model will be selected and calibrated to the observed conditions; the data collection, mapping and modeling efforts will be synthesized to formulate a conceptual model of the regional hydrogeology; and a draft report prepared including the conceptual model, data, maps and study methods.

Phase 2 - Delineation of Zones of Contribution

The regional screening model will be used to determine boundary conditions for "sub-models" that incompass the 13 municipal supply systems within the county; ZOC analyses will be performed for the municipal supply wells within the county; regional and submodel development will be documented; and ZOCs will be delineated.

Phase 3 -- Education and Outreach

Educational and outreach materials will be prepared by selecting pertinent information from the hydrogeologic and modeling reports and working with project partners in Sauk County to identify appropriate presentation opportunities. A summary of the project findings and modeling results will be presented to local boards and civic groups.
COOPERATOR: Wisconsin Geological and Natural History Survey

LOCATION: Sauk County

PROJECT CHIEF: Charles Dunning PERIOD OF PROJECT: July 2000-Continuing

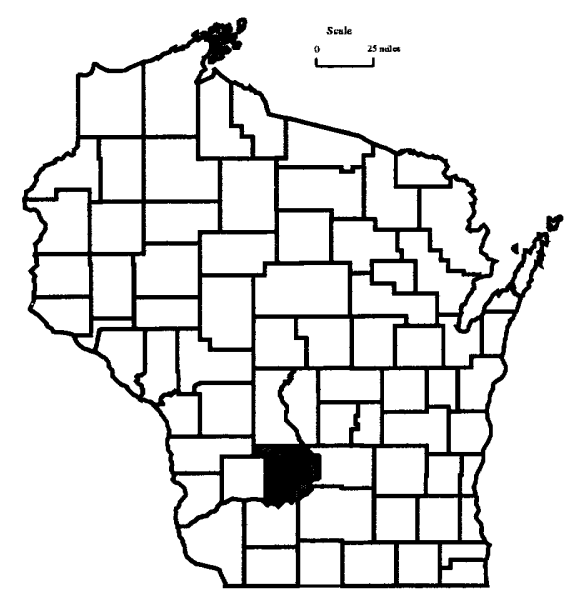


PROGRESS (July 2000 to June 2001): Phase 1 is being completed. Construction of an analytic element (AE) regional flow model using GFLOW software is nearly complete. The AE model will be used to test conceptual models of the hydrogeologic system and to direct additional field work. Phase 2 is underway. ZOCs are being developed for 13 municipalities.

PLANS (July 2001 to June 2002): Phase two will be completed and phase three started. Existing data will be field checked as needed, and additional field work performed as necessary. The data collection, mapping and modeling efforts will be synthesized to formulate a conceptual model of the regional hydrogeology. 


\section{PROJECT COLLABORATION WITH THE BIOLOGICAL RESOURCES DIVISION AT LA CROSSE, WI 22200}

PROBLEM: The Mississippi River is one of the world's major river systems in size, habitat diversity, and biological productivity. The Biological Resources Division (BRD) Environmental Science Center in LaCrosse, Wisconsin, provides scientific understanding, information, and technologies needed to support sound management of biological resources on the Upper Mississippi River. There is a need to bring the BRD expertise into the Wisconsin District (WRD) projects and in return provide hydrologic expertise and experience into the BRD investigations. This project will increase collaboration between the two divisions.

OBJECTIVE: The purpose of the project is to enhance BRD and WRD collaboration in investigations such as nitrogen budgets and the resulting biological impacts; urbanization effects on backwater area biota; mercury, PCB, cadmium, and pesticide impacts in zebra mussels; sedimentation patterns and the resulting effects on mussels, paddlefish, and navigation; and hydrologic assistance in assessing trends in the Upper Mississippi River long-term monitoring program.

\begin{abstract}
APPROACH: One WRD hydrologist will work in the LaCrosse BRD office on a half-time basis. The physical relocation of one hydrologist is expected to enhance the collaboration for numerous personnel between two divisions. Many of the collaborative investigations are expected to focus on the Upper Mississippi River area although enhanced collaboration is expected throughout the Wisconsin District.
\end{abstract}

PROGRESS (July 2000 to June 2001): Six projects presently have collaborating BRD and WRD personnel.

PLANS (July 2001 to September 2001): The Middleton WRD hydrologist will continue to work in LaCrosse two days per week to enhance BRD/WRD collaboration. Project is expected to continue beyond September 2001.
COOPERATOR:

Biological Resources Division, LaCrosse, WI

LOCATION:

LaCrosse County

PROJECT CHIEF:

Jeffrey Steuer

PERIOD OF PROJECT:

October 2000 to September 2001

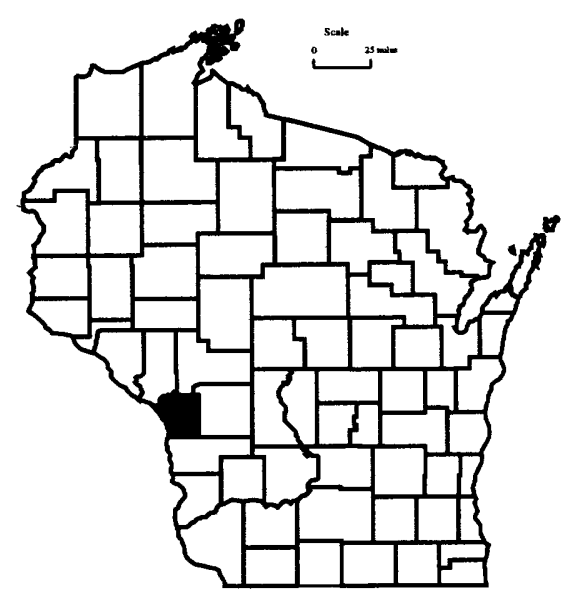




\section{OCCURRENCE AND VARIABILITY OF PATHOGENS IN WISCONSIN'S URBAN STREAMS, WI 22300}

COOPERATOR:

\author{
Wisconsin Department of \\ Natural Resources
}

LOCATION:

Milwaukee area

\section{PROJECT CHIEF:}

\section{Robert Waschbusch \\ Steve Corsi}

\section{PERIOD OF PROJECT:}

March 2001 to December 2003

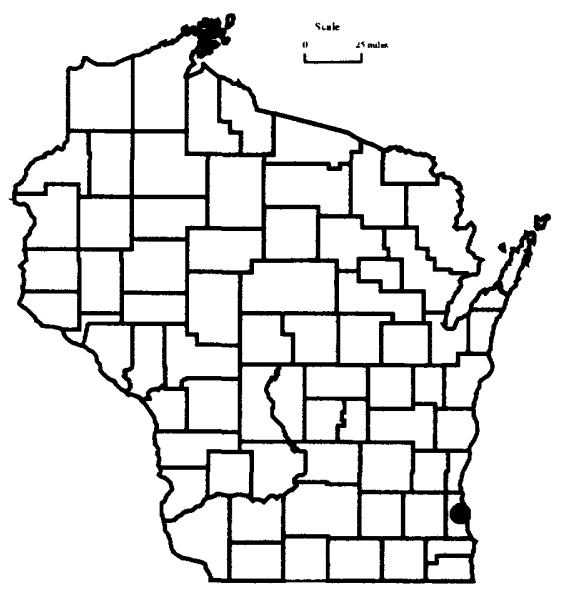

PROBLEM: Water-borne pathogens are a great concern to water-quality managers because of the potential impact on human health, aquatic life, and recreational use. Nowhere have pathogens been more in the public eye than Milwaukee, Wisconsin, where a 1993 Cryptosporidium outbreak was blamed for the death of over 100 people. In addition, recent Milwaukee beach closures have brought renewed concerns before an anxious public over area-wide sanitary and stormwater management. The origins of pathogenic organisms can be many and difficult to delineate. Obviously, sanitary sewer and combined sewer overflows can be a major source of pathogens originating from human fecal material. Sanitary sewer overflow (SSO) or bypassing is a technique used by sanitation utilities to relieve possible backup and surcharging problems during wetweather periods. In 1999 alone, 120 bypasses were reported by municipalities in Wisconsin (WDNR report) and 87 of these were associated with storm events. They are not confined to just the large metropolitan areas. They occur in cities and villages of all sizes and in all geographic regions of the state. Though not as prevalent as SSOs on a state-wide basis, combined sewers and their associated overflows (CSO) may also be important localized sources of pathogens. A third important source of pathogens is runoff water from storm sewers and diffuse inputs. Past research has shown microbial densities in stormwater runoff to be similar to those found in diluted raw sewage. Sources of these organisms include livestock, beavers, pets, and waterfowl. The documented presence of pathogenic organisms, such as Giardia, Cryptosporidium, Salmonellae, and Pseudomonas aeruginosa in storm sewers with no sanitary sewer connections, suggests that diffuse or nonpoint sources of these microorganisms may be an overlooked water-quality issue.

OBJECTIVE: The overall goal of this project is to provide a greater understanding of the occurrence of pathogenic organisms in urban streams. Specific objectives include: (1) determine concentrations of pathogenic indicators and specific pathogens in urban streams of different sizes, land uses, and point source inputs; (2) determine ambient concentrations of total suspended solids, BOD, total phosphorus, and chloride; (3) collect 13 rounds of samples at each site- 9 event samples and 4 baseflow samples; (4) explore the resulting data in an attempt to develop relations between watershed size, major land use, hydrologic and meteorological conditions, and water-quality parameters identified above; and (5) determine sources and relative contributions of $E$. coli bacteria to urban streams by use of strain identification and typing.

APPROACH: The USGS will operate two continuous monitoring stations-one at the mouth of the Milwaukee River in Milwaukee and one further up in the Milwaukee River watershed on Cedar Creek at Grafton. The Wisconsin Department of Natural Resources (WDNR) will collect samples at numerous streams in the Milwaukee area. The focus of this study will be a synoptic survey of 12 stream sites in the Milwaukee metropolitan area and 2 in the Superior area. Milwaukee sites will be selected to spatially cover the 
watershed draining to the Milwaukee Harbor. All sites will be selected to represent a range of water-course size, land use (residential, industrial, open space), and point-source input locations (CSO, SSO, and stormwater discharges). A total of 14 stream sites will be chosen, with some streams having more than one site to examine downstream longitudinal changes. The sampling goal will be to collect a total of 13 grab samples at each site (flow composite samples at the USGS sites), 9 during periods of high flow and 4 during base-flow conditions. Sampling will be spaced to address seasonal differences, and will occur over a period of 1-1/2 years. Recent advances in genetic strain identification will be used in conjunction with the sampling effort to attempt to identify the sources of $E$. coli. An analysis of this data will provide an assessment of the potential risks from the pathogenic presence.

PROGRESS (March 2001 to June 2001): Monitoring sites have been selected and installation of the USGS automated sites has been completed. The first base-flow sample was collected at the two USGS sites on April 8, 2001.

PLANS (July 2001 to June 2002): The three remaining baseflow samples will be collected-one in the fall of 2001 and one in the winter of 2001-2002. Event samples will be collected from spring 2001 to fall 2002. These samples will be spaced to address seasonal differences. 


\section{MENOMONEE VALLEY GROUND-WATER MODEL, WI 22400}

COOPERATOR:

City of Milwaukee

\section{LOCATION: \\ Menomonee Valley, Milwaukee}

PROJECT CHIEF:

Daniel Feinstein

PERIOD OF PROJECT:

February 2001 to September 2001
PROBLEM: The City of Milwaukee and the U.S. Environmental Protection Agency (USEPA), as part of an effort to promote "brownfield" development, have funded a series of data collection and modeling studies to determine the fate of recharge to valley lands adjacent to Lake Michigan. Two major receptors exist for recharge that flows through contaminated fill-the surface-water estuary and a Deep Tunnel system constructed about 200 feet below land surface to store runoff. The overall objective of these studies is to delineate the contributing areas for these receptors in order to determine how best to evaluate potential environmental concerns.

OBJECTIVES: The objectives are to (1) build on an existing analytical element model of the Menomonee Valley by extracting a three-dimensional MODFLOW model from the one-layer GFLOW model; (2) compare the results produced by GFLOW and MODFLOW especially with respect to the fate of recharge to the Valley; and (3) calculate travel times to receptors such as the river estuary and the ISS based on the MODFLOW results.

APPROACH: A step-wise modeling approach was used in which a regional one-layer analytic element model simulates the flow system, but also furnishes boundary conditions for a local MODFLOW model. The MODFLOW model is capable of fully addressing three-dimensional flow from the water table to the Deep Tunnel.

PROGRESS (February 2001 to June 2001): The MODFLOW model was constructed with a complicated three-dimensional geometry and boundary conditions extracted from the accompanying updated GFLOW model. Extensive calibration has been performed to water-table measurements, vertical gradients, and estimated fluxes in the Deep Tunnel. The capture zones corresponding to the surface water and Deep Tunnel receptors have been mapped. They compare favorably with the GFLOW results. Particle tracking has been employed to construct isochron maps showing the expected fate of recharge from particular locations in the Menomonee Valley. The sensitivity of these results to recharge rate, vertical hydraulic conductivity, and effective porosity has been evaluated. The results have been shared with a wide range of interested parties including regulatory agencies and consultants charged with performing natural attenuation analysis.

PLANS (July 2001 to June 2002): A USGS Water-Resources Investigations Report on the GFLOW and MODFLOW modeling will be prepared and reviewed prior to submittal to the city of Milwaukee. 


\section{MILWAUKEE METROPOLITAN SEWERAGE DISTRICT CORRIDOR STUDY, WI 22500}

\begin{abstract}
PROBLEM: The Milwaukee Metropolitan Sewerage District (MMSD) has a watercourse improvement program that is designed to integrate flood control with habitat and water-quality protection and enhancement. The MMSD Corridor Study will compile and collect historical and existing hydrologic, geographic, physical, biological, and chemical data for perennial streams and selected intermittent watercourses and their adjacent corridors within the MMSD planning area. The data will be used to help identify existing waterway limitations, and to evaluate and forecast the potential impacts or improvements from watercourse modifications. The MMSD Corridor Study is a cooperative effort between many local, state, and federal agencies that are represented on the Steering Committee. The Steering Committee is made up of members from the Milwaukee Metropolitan Sewerage District, the U.S. Geological Survey (USGS), the Wisconsin Department of Natural Resources (WDNR), the Southeastern Wisconsin Regional Planning Commission (SEWRPC), UW-Milwaukee, Marquette University, Wisconsin Lutheran College, and others.
\end{abstract}

OBJECTIVE: The primary objectives of the MMSD Corridor study include: (1) evaluating historic impacts and forecasting potential impacts of planned MMSD projects, (2) creating a comprehensive inventory of corridor conditions, (3) establishing a baseline assessment of existing watercourse and corridor conditions, (4) determining the existing and potential water-use objectives for watercourse reaches, (5) following up on flood control, habitat and waterquality improvement or protection projects to verify anticipated results, evaluate current technologies, and identify adjustments for future projects, and (6) providing long-term surveillance of stream and corridor conditions to monitor project impacts, track changes in impaired and unimpaired reaches, provide additional inventory information, and allow early detection of newly impaired reaches.

APPROACH: There is a three-phase approach to the MMSD Corridor study. Phase I will include the development of a data warehouse and evaluation of analytical procedures. A data warehouse will be compiled from different data sets with the purpose of assembling data from within the corridor study area. The assembled data will then be analyzed to summarize existing conditions and identify data gaps and future data needs. Phase II will consist of a baseline inventory of water-quality conditions in the MMSD study area. An intensive data-collection and analysis effort will be made to fill in data gaps and update historic data to define the existing characteristics of the watercourses and corridors and serve as the basis for future impact evaluations and trend analyses. Phase III will be the development of a long-term inventory of water-quality data and maintenance of the data warehouse. The data collected as part of field activities and the data maintained in the data warehouse will be used to assess future impacts, measure the benefits of watercourse modifications and other watershed management efforts, and detect new watercourse concerns or impairments.
COOPERATOR:

Milwaukee Metropolitan

Sewerage District

\section{LOCATION:}

Milwaukee County and parts of

Waukesha, Washington, Ozaukee, and Racine Counties

PROJECT CHIEF: Morgan A. Schmidt

PERIOD OF PROJECT: February 2001 - Continuing

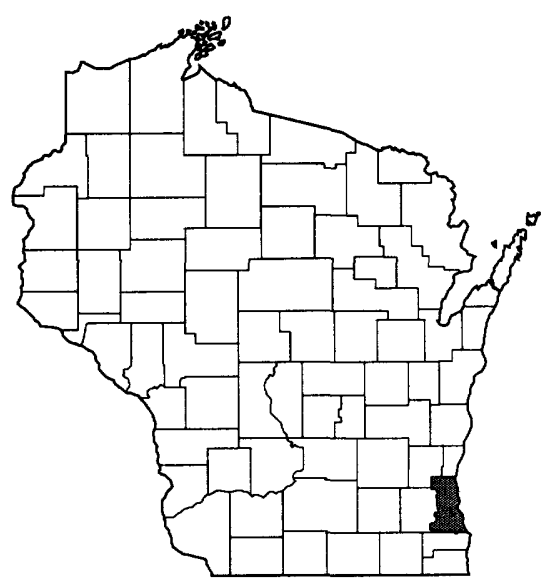


PROGRESS (February 2001 to June 2001): Meetings with Steering Committee members have focused the scope of the project with respect to space, time, and data type concerns. The first data set to be incorporated into the data warehouse will be the MMSD waterquality data.

A database design optimized for query retrievals has been created. In designing the database, a document describing data elements necessary for water-quality reporting produced by the National Water Quality Methods Comparability Board was used.

A literature review of studies and research reports in the MMSD study area is underway. The literature search is nearing completion and the summarization of relevant references is now in progress.

PLANS (July 2001 to June 2002): A meeting is planned for mid-summer to show the database design and the ad-hoc query tool (called Discoverer) to the Steering Committee members. Training for "super users" and general users is also planned for mid to late summer. Several super users, one from each major agency, will be trained so they can assist other users in their own agency with using the Discoverer software and so they will be able to create relatively complex queries using Discoverer on their own. General users will only run "canned" queries created either by a database developer or one of the super users.

The initial set of data will be loaded before the mid-summer Steering Committee meeting. The Discoverer tool will be initialized for queries as well. A web page using Oracle Portal will be created.

Incorporation of more datasets, possibly including data from the USGS, WDNR, U.S. Environmental Protection Agency (STORET), and various universities (UW-Milwaukee, Marquette, and Wisconsin Lutheran College) and community groups will continue.

The literature review will proceed, with the end product including a list of citations as well as tables summarizing the data to be found in each reference.

Initial work summarizing the data in the MMSD Corridor study data warehouse will begin in mid to late summer 2002. 


\section{WISCONSIN DISTRICT PUBLICATIONS}

The reports listed below are a partial list of reports prepared by the Wisconsin District in cooperation with other agencies since 1948. The list contains reports that are relevant and contribute significantly to understanding the hydrology of Wisconsin's water resources.

The reports published in a U.S. Geological Survey series are for sale by the U.S. Geological Survey, Box 25286, Federal Center, Denver, CO 80225. Prepayment is required. Remittance should be sent by check or money order payable to the U.S. Geological Survey. Prices can be obtained by writing to the above address or by calling 1-888-ASK-USGS. Copies of reports published by the University of Wisconsin, Geological and Natural History Survey, can be obtained from their office at 3817 Mineral Point Road, Madison, WI 53705.

\section{WATER-SUPPLY PAPERS}

Kammerer, P.A., Jr., and Krug, W.R., 1993, Wisconsin stream water quality, in U.S. Geological Survey, National water summary 1990-91-Hydrologic events and stream water quality: U.S. Geological Survey Water-Supply Paper 2400, p. 561-568.

Melcher, N.B., and Walker, J.F., 1992, Evaluation of selected methods for determining streamflow during periods of ice effect: U.S. Geological Survey Water-Supply Paper 2378, 47 p

U.S. Geological Survey, 1991, National water summary 1988-89Hydrologic Events and Floods and Droughts: U.S. Geological Survey Water-Supply Paper 2375, 591 p.

U.S. Geological Survey, 1990, National water summary 1987Hydrologic events and water supply and use: U.S. Geological Survey Water-Supply Paper 2350, 553 p.

1988, National water summary 1986-Hydrologic events, selected water-quality trends, and ground-water quality: U.S. Geological Survey Water-Supply Paper 2325, 569 p.

1986, National water summary 1985-Hydrologic events and surface-water resources: U.S. Geological Survey Water-Supply Paper 2300, 506 p.

1985, National water summary 1984-Hydrologic events, selected water-quality trends, and ground-water resources: U.S. Geological Survey Water-Supply Paper 2275, 467 p.

1984, National water summary 1983-Hydrologic events and issues: U.S. Geological Survey Water-Supply Paper 2250, 243 p.

Batten, W.G., and Hindall, S.M., 1980, Sediment deposition in the White River Reservoir, northwestern Wisconsin: U.S. Geological Survey Water-Supply Paper 2069, 30 p.

Sherrill, M.G., 1978, Geology and ground water in Door County, Wisconsin, with emphasis on contamination potential in the Silurian dolomite: U.S. Geological Survey Water-Supply Paper 2047,38 p.

Hurtgen, D.C., 1975, Summary of floods, June 29-30 in southwestern Wisconsin, in Summary of floods in the United States during 1969: U.S. Geological Survey Water-Supply Paper 2030, p. 116119.

Bell, E.A., and Sherrill, M.G., 1974, Water availability in central Wisconsin-an area of near-surface crystalline rock: U.S. Geological Survey Water-Supply Paper 2022, 32 p.

Novitzki, R.P., 1973, Improvement of trout streams in Wisconsin by augmenting low flows with ground water: U.S. Geological Survey Water-Supply Paper 2017, 52 p.
Oakes, Edward, Field, S.J., and Seeger, L.P., 1973, The Pine-Popple River basins-hydrology of a wild river area, northeastern Wisconsin: U.S. Geological Survey Water-Supply Paper 2006, $57 \mathrm{p}$.

Hamilton, L.J., 1971, Water for cranberry culture in the Cranmoor area of central Wisconsin: U.S. Geological Survey Water-Supply Paper 1999-I, $20 \mathrm{p}$.

Hurtgen, D.C., 1972, Floods of March 27-April 4, 1967, in northwestern and west-central Wisconsin, in summary of floods in the United States during 1967: U.S. Geological Survey WaterSupply Paper 1880-C, p. 7-10.

Hutchinson, R.D., 1970, Ground-water resources of Racine and Kenosha Counties, Wisconsin: U.S. Geological Survey WaterSupply Paper 1878, $63 \mathrm{p}$.

Olcott, P.G., 1966, Geology and water resources of Winnebago County, Wisconsin: U.S. Geological Survey Water-Supply Paper $1814,61 \mathrm{p}$.

Weeks, E.P., Erickson, D.W., and Holt, C.L.R., Jr., 1965, Hydrology of the Little Plover River basin, Portage County, Wisconsin, and the effects of water-resources development: U.S. Geological Survey Water-Supply Paper 1811, 78 p.

Green, J.H., and Hutchinson, R.D., 1965, Ground-water pumpage and water-level changes in the Milwaukee-Waukesha area, Wisconsin, 1950-61: U.S. Geological Survey Water-Supply Paper 1809-I, 19 p.

Summers, W.K., 1965, Geology and ground-water resources of Waushara County, Wisconsin: U.S. Geological Survey WaterSupply Paper 1809-B, 32 p.

Holt, C.L.R., Jr., and Knowles, D.B., 1963, The water situation in Wisconsin in the role of ground water in the national water situation: U.S. Geological Survey Water-Supply Paper 1800, p. 943960

Cline, D.R., 1965, Geology and ground-water resources of Dane County, Wisconsin: U.S. Geological Survey Water-Supply Paper 1779-U, $64 \mathrm{p}$

Holt, C.L.R., Jr., 1965, Geology and water resources of Portage County, Wisconsin: U.S. Geological Survey Water-Supply Paper $1796,77 \mathrm{p}$

Berkstresser, C.F., Jr., 1964, Ground-water resources of Waupaca County, Wisconsin: U.S. Geological Survey Water-Supply Paper 1669-U, $38 \mathrm{p}$

Knowles, D.B., 1964, Ground-water conditions in the Green Bay area, Wisconsin, 1950-60: U.S. Geological Survey Water-Supply Paper 1669-J, $37 \mathrm{p}$ 
Cline, D.R., 1963, Hydrology of upper Black Earth Creek basin, Wisconsin, with a section on surface water by M.W. Busby: U.S. Geological Survey Water-Supply Paper 1669-C, 27 p.

Collier, C.R., 1963, Sediment characteristics of small streams in southern Wisconsin, 1954-59: U.S. Geological Survey WaterSupply Paper 1669-B, 34 p.

LeRoux, E.F., 1963, Geology and ground-water resources of Rock County, Wisconsin: U.S. Geological Survey Water-Supply Paper $1619-\mathrm{X}, 50 \mathrm{p}$

Newport, T.G., 1962, Geology and ground-water resources of Fond du Lac County, Wisconsin: U.S. Geological Survey Water-Supply Paper 1604, 52 p.

Knowles, D.B., Dreher, F.C., and Whetstone, G.W., 1964, Water resources of the Green Bay area, Wisconsin: U.S. Geological Survey Water-Supply Paper 1499-G, 66 p.

LeRoux, E.F., 1957, Geology and ground-water resources of Outagamie County, Wisconsin: U.S. Geological Survey WaterSupply Paper 1421, 57 p.

Harger, A.H., and Drescher, W.J., 1954, Ground-water conditions in south-western Langlade County, Wisconsin: U.S. Geological Survey Water-Supply Paper 1294, 39 p.

Foley, F.C., Walton, W.D., and Drescher, W.J., 1953, Ground-water conditions in the Milwaukee-Waukesha area, Wisconsin: U.S. Geological Survey Water-Supply Paper 1229, 96 p.

\section{HYDROLOGIC INVESTIGATIONS ATLASES}

Kammerer, Phil A., Jr., Trotta, Lee C., Krabbenhoft, David P., and Lidwin, R.A., 1998, Geology, ground-water flow, and dissolved-solids concentrations in ground water along hydrogeologic sections through Wisconsin aquifers, U.S. Geological Survey Hydrologic Investigations Atlas, HA-731, 4 sheets.

Gebert, W.A., Graczyk, D.J., and Krug, W.R., 1987, Average annual runoff in the United States, 1951-80: U. S. Geological Survey Hydrologic Investigations Atlas HA-710, 1 sheet.

Hughes, P.E., Hannuksela, J. S., and Danchuk, W.J., 1981, Flood of July 1-5, 1978, on the Kickapoo River, South-western Wisconsin: U.S. Geological Survey Hydrologic Investigations Atlas HA653,7 sheets.

Oakes, E.L., and Cotter, R.D., 1975, Water resources of Wisconsinupper Wisconsin River basin: U.S. Geological Survey Hydrologic Investigations Atlas HA-536, 3 sheets.

Young, H.L., and Skinner, E.L., 1974, Water resources of WisconsinLake Superior basin: U.S. Geological Survey Hydrologic Investigations Atlas HA-524, 3 sheets.

Hindall, S.M., and Borman, R.G., 1974, Water resources of Wisconsin-lower Wisconsin River basin: U.S. Geological Survey Hydrologic Investigations Atlas HA-479, 3 sheets.

Young, H.L., and Borman, R.D., 1973, Water resources of Wisconsin-Trempealeau-Black River basin: U.S. Geological Survey Hydrologic Investigations Atlas HA-474, 4 sheets.

Oakes, E.L., and Hamilton, L.J., 1973, Water resources of Wisconsin-Menominee-Oconto-Peshtigo River basin, U.S. Geological Survey Hydrologic Investigations Atlas HA-470, 4 sheets.

Hindall, S.M., and Skinner, E.L., 1973, Water resources of Wisconsin-Pecatonica-Sugar River basin: U.S. Geological Survey Hydrologic Investigations Atlas HA-453, 3 sheets.
Young, H.L., and Hindall, S.M., 1973, Water resources of Wisconsin-St. Croix River basin: U.S. Geological Survey Hydrologic Investigations Atlas HA-451, 4 sheets.

Skinner, E.L., and Borman, R.G., 1973, Water resources of Wisconsin-Lake Michigan basin: U.S. Geological Survey Hydrologic Investigations Atlas HA-432, 4 sheets.

Shearman, J.O., and Holmstrom, B.K., 1971, Floods on Rock River in southwestern Jefferson County, Wisconsin: U.S. Geological Survey Hydrologic Investigations Atlas HA-413, 1 sheet.

1971, Floods on Rock River in northeastern Jefferson County, Wisconsin: U.S. Geological Survey Hydrologic Investigations Atlas HA-394, 1 sheet.

Sherman, J.O., 1970, Floods on Rock River in northern Rock County, Wisconsin: U.S. Geological Survey Hydrologic Investigations Atlas HA-393, 1 sheet.

Gebert, W.A., 1971, Low-flow frequency of Wisconsin streams: U.S. Geological Survey Hydrologic Investigations Atlas HA- 390, 1 sheet.

Young, H.L., and Hindall, S.M., 1972, Water resources of Wisconsin-Chippewa River basin: U.S. Geological Survey Hydrologic Investigations Atlas HA-386, 4 sheets.

Hindall, S.M., and Flint, R.F., 1970, Sediment yields of Wisconsin streams: U.S. Geological Survey Hydrologic Investigations Atlas HA-376, 1 sheet.

Devaul, R.W., and Green, J.H., 1971, Water resources of Wisconsincentral Wisconsin River basin: U.S. Geological Survey Hydrologic Investigations Atlas HA-367, 4 sheets.

Cotter, R.D., Hutchinson, R.D., Skinner, E.L., and Wentz, D.A., 1969 , Water resources of Wisconsin-Rock-Fox River basin: U.S. Geological Survey Hydrologic Investigations Atlas HA-360, 4 sheets.

Olcott, P.G., 1968, Water resources of Wisconsin-Fox-Wolf River basin: U.S. Geological Survey Hydrologic Investigations Atlas HA-321, 4 sheets.

U.S. Geological Survey, 1965, Preliminary map of the conterminous United States showing depth to and quality of shallowest ground water containing more than 1,000 parts per million dissolved solids: U.S. Geological Survey Hydrologic Investigations Atlas HA-199, 31 p., 2 sheets.

\section{PROFESSIONAL PAPERS}

Young, H.L., 1992, Summary of ground-water hydrology of the Cambrian-Ordovician aquifer system in the northern midwest, United States: U.S. Geological Survey Professional Paper 1405-A, 55 p.

1992, Hydrogeology of the Cambrian-Ordovician aquifer system in the northern midwest, United States: U.S. Geological Survey Professional Paper 1405-B, 99 p., 1 pl.

Mandle, R.J., and Kontis, A.L., 1992, Simulation of regional groundwater flow in the Cambrian-Ordovician aquifer system in the northern midwest, United States: U.S. Geological Survey Professional Paper 1405-C, $97 \mathrm{p}$

Siegel, D.I., 1989, Geochemistry of the Cambrian-Ordovician aquifer system in the northern midwest, United States: U.S. Geological Survey Professional Paper 1405-D, 76 p.

Green, J.H., 1968, The Troy Valley of southeastern Wisconsin: U.S Geological Survey Professional Paper 600-C, p. 135-139. 
Carey, K.L., 1967, The underside of river ice, St. Croix River, Wisconsin: U.S. Geological Survey Professional Paper 575-C, p. 195-199.

1966, Observed configuration and computed roughness of the underside of river ice, St. Croix River, Wisconsin: U.S Geological Survey Professional Paper 550-B, p. 192-198.

Weeks, E.P., 1964, Field methods for determining vertical permeability and aquifer anisotropy: U.S. Geological Survey Professional Paper 501-D, p. 193-198.

1964 , Use of water-level recession curves to determine the hydraulic properties of glacial outwash in Portage County, Wisconsin: U.S. Geological Survey Professional Paper 501-B, p. 181-184.

\section{WATER-RESOURCES INVESTIGATIONS REPORTS}

Robertson, D.M., 2000, One-dimensional simulation of stratification and dissolved oxygen in McCook Reservoir, Illinois: U.S. Geological Survey Water-Resources Investigations Report 00-4258, $17 \mathrm{p}$.

Steuer, J.J., 2000, A mass-balance approach for assessing PCB movement during remediation of a PCB-contaminated deposit on the Fox River, Wisconsin: U.S. Geological Survey Water-Resources Investigations Report 00-4245, 8 p.

Robertson, D.M., and Rose, W.J., 2000, Hydrology, water quality, and phosphorus loading of Little St. Germain Lake, Vilas County, Wisconsin: U.S. Geological Survey Water-Resources Investigations Report 00-4209, 8 p.

Schmidt, M.A., Richards, K.D., and Scudder, B.C., 2000, Surface-water quality, Oneida Reservation and vicinity, Wisconsin, 1997-98, U.S. Geological Survey Water-Resources Investigations Report $00-4179,30 \mathrm{p}$.

Hunt, R.J., and Steuer, J.J., 2000, Simulation of the recharge area for Frederick Springs, Dane County, Wisconsin: U.S. Geological Survey Water-Resources Investigations Report 00-4172, 33 p.

Hunt, R.J., Lin, Y., Krohelski, J.T., and Juckem, P.F., 2000, Simulation of the shallow hydrologic system in the vicinity of Middle Genesee Lake, Wisconsin, using analytic elements and parameter estimation: U.S. Geological Survey Water-Resources Investigations Report 00-4136, 16 p.

Saad, D.A., and Robertson, D.M., 2000, Water-resources-related information for the St. Croix Reservation and vicinity, Wisconsin: U.S. Geological Survey Water-Resources Investigations Report $00-4133,65 \mathrm{p}$.

Grannemann, N.G., Hunt, R.J., Nicholas, J.R., Reilly, T.E., and Winter, T.C., 2000, The importance of ground water in the Great Lakes Region: U.S. Geological Survey Water-Resources Investigations Report 00-4008, 14 p.

Brown, Timothy A., Dunning, Charles P., and Sharpe, Jennifer B., 2000, Altitude, depth, and thickness of the Galena-Platteville bedrock unit in the subcrop area of Illinois and Wisconsin: U.S. Geological Survey Water-Resources Investigations Report 974054-C, 4 sheets.

Lenz, Bernard N. and Rheaume, S.J., 2000, Benthic invertebrates of fixed sites in the Western Lake Michigan Drainages, Wisconsin and Michigan, 1993-95: U.S. Geological Survey Water-Resources Investigations Report 95-4211-D, 30 p.
Krohelski, J.T., Feinstein, D.T., and Lenz, B.N., 1999, Simulation of stage and hydrologic budget for Shell Lake, Washburn County, Wisconsin: U.S. Geological Survey Water-Resources Investigations Report 99-4209, 23 p.

Batten, W.G., Yeskis, D.J., and Dunning, C.P., 1999, Hydrogeologic properties of the Ordovician Sinnipee Group at test well BN483, better brite superfund site, De Pere, Wisconsin: U.S. Geological Survey Water-Resources Investigations Report 99$4199,19 \mathrm{p}$.

Waschbusch, R.J., 1999, Evaluation of the effectiveness of an urban stormwater treatment unit in Madison, Wisconsin, 1996-97: U.S. Geological Survey Water-Resources Investigations Report 99$4195,49 \mathrm{p}$.

Steuer, Jeffrey S., Hall, David W., and Fitzgerald, Sharon A., 1999, Distribution and transport of polychlorinated biphenyls and associated particulates in the Hayton Millpond, South Branch Manitowoc River, 1993-95: U.S. Geological Survey Water-Resources Investigations Report 99-4101, 20 p.

Steuer, Jeffrey S., Fitzgerald, Sharon A., and Hall, David, 1999, Distribution and transport of polychlorinated biphenyls and associated particulates in the Milwaukee River system, Wisconsin, 1993-95: U.S. Geological Survey Water-Resources Investigations Report 99-4100, $37 \mathrm{p}$.

Fitzpatrick, Faith A., Knox, James C., and Whitman, Heather E., 1999, Effects of historical land-cover changes on flooding and sedimentation, North Fish Creek, Wisconsin: U.S. Geological Survey Water-Resources Investigations Report 99-4083, $12 \mathrm{p}$.

Waschbusch, R.J., Selbig, W.R., and Bannerman, R.T., 1999, Sources of phosphorus from two urban residential basins in Madison, Wisconsin, 1994-95, U.S. Geological Survey Water-Resources Investigations Report 99-4021, $47 \mathrm{p}$.

Saad, David A., and Schmidt, Morgan A., 1999, Water-resources-related information for the Oneida Reservation and vicinity, Wisconsin, U.S. Geological Survey Water-Resources Investigations Report 98-4266, 57 p.

Saad, David A., and Thorstenson, Donald C., 1998, Flow and geochemistry along shallow ground-water flowpaths in an agricultural area in southeastern Wisconsin: U.S. Geological Survey Water-Resources Investigations Report 98-4179, 62 p.

Robertson, Dale M., 1998, Evaluation of the surface-water sampling design in the Western Lake Michigan Drainages in relation to environmental factors affecting water quality at base flow, U.S. Geological Survey Water-Resources Investigations Report 98-4072, $53 \mathrm{p}$.

Walker, John F., Saad, David A., and Krohelski, James T., 1998, Optimization of ground-water withdrawal in the lower Fox River communities, Wisconsin: U.S. Geological Survey WaterResources Investigations Report 97-4218, 24 p.

Richards, Kevin D., Sullivan, Daniel J., and Stewart, Jana S., 1998, Surface-water quality at fixed sites in the Western Lake Michigan Drainages, Wisconsin and Michigan, and the effects of natural and human factors, 1993-95, U.S. Geological Survey Water-Resources Investigations Report 97-4208, 40 p.

Stewart, Jana S., 1998, Combining satellite data with ancillary data to produce a refined land-use/land-cover map: U.S. Geological Survey Water-Resources Investigations Report 97-4203, 11 p., 3 pl.

Conlon, T.D., 1998, Hydrogeology and simulation of ground-water flow in the sandstone aquifer, northeastern Wisconsin: U.S. Geological Survey Water-Resources Investigations Report 97-4096, 60 p., 1 pl. 
Elder, John F., Manion, Bart J., and Goddard, Gerald L., 1997, Mesocosm experiments to assess factors affecting phosphorus retention and release in an extended Wisconsin wetland: U.S. Geological Survey Water-Resources Investigations Report 97$4272,14 \mathrm{p}$

Steuer, Jeffrey, Selbig, William, Hornewer, Nancy, and Prey, Jeffrey, 1997, Sources of contamination in an urban basin in Marquette, Michigan and an analysis of concentrations, loads, and data quality: U.S. Geological Survey Water-Resources Investigations Report $97-4242,25 \mathrm{p}$.

Peters, Charles A., et al, 1997, Environmental setting and implications for water quality in the Western Lake Michigan drainage: U.S. Geological Survey Water-Resources Investigations Report 97$4196,79 \mathrm{p}$.

Scudder, Barbara C., Sullivan, Daniel J., Fitzpatrick, Faith A., and Rheaume, Stephen J., 1997, Trace elements and synthetic organic compounds in biota and streambed sediment of the Western Lake Michigan drainages, 1992-1995: U.S. Geological Survey WaterResources Investigations Report 97-4192, 34 p.

Fitzgerald, Sharon A., 1997, Results of quality-control sampling of water, bed sediment, and tissue in the Western Lake Michigan drainages study unit of the national water-quality assessment program: U.S. Geological Survey Water-Resources Investigations Report 97-4148, $24 \mathrm{p}$

Batten, W.G., Brown, T.A., Mills, P.C., and Sabin, T.J., 1997, Rockstratigraphic nomenclature, lithology, and subcrop area of the Galena-Platteville bedrock unit in Illinois and Wisconsin: U.S. Geological Survey Water Resources Investigations Report 97-4054B, 1 sheet.

Sullivan, Daniel J. and Peterson, Elise M., 1997, Fish communities of benchmark streams in agricultural areas of eastern Wisconsin: Water Resources Investigations Report 96-4038-D, 23 p.

Sullivan, Daniel J., 1997, Fish communities of fixed sites in the Western Lake Michigan drainages, Wisconsin and Michigan, 1993-95: U.S. Geological Survey Water-Resources Investigations Report 95-4211-C, $23 \mathrm{p}$.

Fitzpatrick, Faith A., and Giddings, Elise M.P., 1997, Stream habitat characteristics of fixed sites in the Western Lake Michigan drainages, Wisconsin and Michigan, 1993-95: U.S. Geological Survey Water-Resources Investigations Report 95-4211-B, 58 p.

Garn, Herbert S., Olson, Daniel L., Seidel, Tracy L., and Rose, William J., 1996, Hydrology and water quality of Lauderdale Lakes, Walworth County, Wisconsin, 1993-94: U.S. Geological Survey Water-Resources Investigations Report 96-4235, 29 p.

Conlon, T.D., 1996, Hydrogeology of the sand and gravel aquifer in the vicinity of the Wild Rose State Fish Hatchery, North-Central Waushara County, Wisconsin: U.S. Geological Survey WaterResources Investigations Report 96-4213, 14 p.

Legg. Andrew D., Bannerman, Roger T., and Panuska, John, 1996, Variation in the relation of rainfall to runoff from residential lawns in Madison, Wisconsin, July and August 1995: U.S. Geological Survey Water-Resources Investigations Report 96-4194, $11 \mathrm{p}$.

Robertson, Dale M., Field, Stephen J., Elder, John F., Goddard, Gerald L., and James, William F., 1996, Phosphorus dynamics in Delavan Lake Inlet, Southeastern Wisconsin, 1994: U.S. Geological Survey Water-Resources Investigations Report 96-4160, $18 \mathrm{p}$.

Robertson, Dale M., 1996, Use of frequency-volume analyses to estimate regionalized yields and load of sediment, phosphorus, and polychlorinated biphenyls to Lakes Michigan and Superior: U.S
Geological Survey Water-Resources Investigations Report 96$4092,47 \mathrm{p}$.

Fitzpatrick, Faith A., Peterson, Elise M., and Stewart, Jana S., 1996 Habitat characteristics of benchmark streams in agricultural areas of Eastern Wisconsin: U.S. Geological Survey Water-Resources Investigations Report 96-4038-B, 35 p.

Rheaume, S.J., Stewart, J.S., and Lenz, Bernard N., 1996, Environmental setting of benchmark streams in agricultural areas of Eastern Wisconsin: U.S. Geological Survey Water-Resources Investigations Report 96-4038-A, 50 p.

Robertson, Dale M., and Saad, David A., 1996, Water-quality assessment of the Western Lake Michigan drainages-analysis of available information on nutrients and suspended sediment, water years 1971-90: U.S. Geological Survey Water Resources Investigations Report 96-4012, $165 \mathrm{p}$

Rose, William J,. and Graczyk, David J., 1996, Sediment transport, particle size, and loads in North Fish Creek in Bayfield County, Wisconsin, water years 1990-91: U.S. Geological Survey WaterResources Investigations Report 95-4222, 18 p.

Batten, W.G., and Lidwin, R.A., 1996, Water resources of the Lac du Flambeau Indian Reservation, Wisconsin, 1981-86: U.S. Geological Survey Water-Resources Investigations Report 94-4025, 42 p., 3 pls.

Sullivan, D.J., Peterson, E.M., and Richards, K.D., 1995, Environmental setting of fixed sites in the Western Lake Michigan Drainages, Michigan and Wisconsin: U.S. Geological Survey WaterResources Investigations Report 95-4211-A, 30 p.

Batten, W. G., and Lidwin, R.A., 1995, Water resources of the Bad River Indian Reservation, northern Wisconsin: U.S. Geological Survey Water-Resources Investigations Report 95-4207, 45 p., $2 \mathrm{pl}$.

Conlon, T. D., 1995, Hydrogeology of southwestern Sheboygan County, Wisconsin, in the vicinity of the Kettle Moraine Springs Fish Hatchery: U.S. Geological Survey Water-Resources Investigations Report 94-4106, 17 p.

Corsi, S. R., and Schuler, J.G., 1995, Discharge ratings for tainter gates and roller gates at Lock and Dam No. 7 on the Mississippi River, La Crescent, Minnesota: U.S. Geological Survey Water Resources Investigations Report 95-4089, 17 p.

DeWild, John F., and Krohelski, James T., 1995, Radon-222 concentrations in ground water and soil gas on Indian Reservations in Wisconsin: U.S. Geological Survey Water-Resources Investigations Report 95-4088, $12 \mathrm{p}$

Kammerer, P.A., Jr., 1995, Ground-water flow and quality in Wisconsin's shallow aquifer system: U.S. Geological Survey Water-Resources Investigations Report 90-4171, 42 p., 2 pl.

Goddard, Gerald L., and Field, Stephen J., 1994, Hydrology and water quality of Whitewater and Rice Lakes in southeastern Wisconsin, 1990-91: U.S. Geological Survey Water-Resources Investigations Report 94-4101, $36 \mathrm{p}$.

Krohelski, James T., Kammerer, Jr., Phil A., and Conlon, Terrence D., 1994, Water resources of the Menominee Indian Reservation of Wisconsin: U.S. Geological Survey Water-Resources Investigations Report 93-4053, 54 p., 4 pl.

Rose, William J., 1993, Hydrology of Little Rock Lake in Vilas County, north-central Wisconsin: U.S. Geological Survey WaterResources Investigations Report 93-4139, 22 p. 
Graczyk, D.J., 1993, Surface-water hydrology and quality, and macroinvertebrate and smallmouth bass populations in four stream basins in southwestern Wisconsin, 1987-90: U.S. Geological Survey Water-Resources Investigations Report 93-4024, 70 p.

Batten, W.G., and Conlon, T.D., 1993, Hydrogeology of glacial deposits in a preglacial bedrock valley, Waukesha County, Wisconsin: U.S. Geological Survey Water-Resources Investigations Report 92-4077, 15 p.

House, L.B., 1993, Simulation of the effects of hypothetical residential development on water levels in Graber Pond, Middleton, Wisconsin: U.S. Geological Survey Water-Resources Investigations Report 92-4029, $10 \mathrm{p}$

Krohelski, J.T., and Lidwin, R.A., 1993, Hydrology and water quality of the Forest County Potawatomi Indian Reservation, Wisconsin: U.S. Geological Survey Water-Resources Investigations Report 91-4136, $24 \mathrm{p}$.

Rose, William J., 1993, Water and phosphorus budgets and trophic state, Balsam Lake, northwestern Wisconsin, 1987-1989: U.S. Geological Survey Water-Resources Investigations Report 914125,28 p.

Field, S.J., 1993, Hydrology and water quality of Powers Lake, southeastern Wisconsin: U.S. Geological Survey Water-Resources Investigations Report 90-4126, 36 p.

Field, Stephen J., 1993, Hydrology and water quality of Wind Lake in southeastern Wisconsin: U.S. Geological Survey WaterResources Investigations Report 91-4107,61 p.

Hughes, P.E., 1993, Hydrology, water quality, trophic status, and aquatic plants of Fowler Lake, Wisconsin: U.S. Geological Survey Water-Resources Investigations Report 91-4076, 44 p.

Krug, William R., Conger, Duane H., and Gebert, Warren A., 1992 , Flood-frequency characteristics of Wisconsin streams: U.S. Geological Survey Water-Resources Investigations Report 914128,185 p., 2 pls.

Rose, W.J., 1992, Sediment transport, particle sizes, and loads in lower reaches of the Chippewa, Black, and Wisconsin Rivers in western Wisconsin: U.S. Geological Survey Water-Resources Investigations Report 90-4124, 38 p.

Wentz, D.A., and Rose, W.J., 1991, Hydrology of Lakes Clara and Vandercook in North-Central Wisconsin: U.S. Geological Survey Water-Resources Investigations Report 89-4204, 24 p.

Patterson, G. L., 1990, Ground-water levels and quality at Crex Meadows Wildlife Area, Burnett County, Wisconsin: U.S. Geological Survey Water-Resources Investigations Report 894129, $19 \mathrm{p}$.

Field, S.J., and Graczyk, D.J., 1990, Hydrology, aquatic macrophytes, and water quality of Black Earth Creek and its tributaries, Dane County, Wisconsin, 1985-86: U.S. Geological Survey WaterResources Investigations Report 89-4089, 44 p.

Krug, W.R., Gebert, W.A., Graczyk, D.J., Stevens, D.L., Jr., Rochelle, B.P., Church, M.R., and Campbell, W.G., 1988, Runoff map for the Northeastern, Southeastern, and Mid-Atlantic United States for water years 1951-80: U.S. Geological Survey WaterResources Investigations Report 88-4094, 44 p.

Rose, William J., 1988, Water resources of the Apostle Islands National Lakeshore, Northern Wisconsin: U.S. Geological Survey Water-Resources Investigations Report 87-4220, 44 p.

Field, Stephen J., and Duerk, Marvin D., 1988, Hydrology and water quality of Delavan Lake in southeastern Wisconsin: U.S.
Geological Survey Water-Resources Investigations Report 87 $4168,61 \mathrm{p}$.

Walker, J.F., Osen, L.L., and Hughes, P.E., 1987, Cost effectiveness of the U.S. Geological Survey's stream-gaging program in Wisconsin: U.S. Geological Survey Water-Resources Investigations Report 86-4125, 44 p.

Krohelski, J.T., Ellefson, B.R., and Storlie, C.A., 1987, Estimated use of ground water for irrigation in Wisconsin, 1984: U.S. Geological Survey Water-Resources Investigations Report 86$4079,12 \mathrm{p} ., 1 \mathrm{pl}$.

House, L.B., 1987, Simulation of unsteady flow in the Milwaukee Harbor Estuary at Milwaukee, Wisconsin: U.S. Geological Survey Water-Resources Investigations Report 86-4050, 19 p.

Conger, D.H., 1986, Estimating magnitude and frequency of floods for Wisconsin urban streams: U.S. Geological Survey WaterResources Investigations Report 86-4005, 18 p.

Graczyk, D.J., 1986, Water quality in the St. Croix National Scenic Riverway, Wisconsin: U.S. Geological Survey Water-Resources Investigations Report 85-4319, 48 p.

Field, S.J., 1986, Relations between precipitation, streamflow, and water quality in the Galena River basin, Wisconsin: U.S. Geological Survey Water-Resources Investigations Report 85$4214,48 \mathrm{p}$.

Emmons, P.J., 1987, An evaluation of the bedrock aquifer system in northeastern Wisconsin: U.S. Geological Survey WaterResources Investigations Report 85-4199, 48 p.

Krug, W.R., and Goddard, G.L., 1986, Effects of urbanization on streamflow, sediment loads, and channel morphology in Pheasant Branch basin near Middleton, Wisconsin: U.S. Geological Survey Water-Resources Investigations Report 85-4068, 82 p.

Cotter, R.D., 1986, Hydrogeology and ground-water quality of Lannon-Sussex Area, northeastern Waukesha County, Wisconsin: U.S. Geological Survey Water-Resources Investigations Report 84-4213, 28 p.

Field, S.J., 1985, Nonpoint-source discharges and water quality of Elk Creek basin, west-central Wisconsin: U.S. Geological Survey Water-Resources Investigations Report 84-4094, 38 p.

Field, S.J., and Lidwin, R.A., 1984, An assessment of nonpoint-source discharges, streamflow, and water quality in Onion River, Wisconsin: U.S. Geological Survey Water-Resource Investigations Report 84-4066, 78 p.

House, L.B., 1984, Effects of urbanization on three ponds in Middleton, Wisconsin: U.S. Geological Survey Water-Resources Investigations Report 84-4051, 17 p.

Kammerer, P.A., Jr., 1984, An overview of ground-water-quality data in Wisconsin: U.S. Geological Survey Water-Resources Investigations Report 83-4239, 58 p.

Krug, W.R., and House, L.B., 1984, Evaluation of alternative reservoir-management practices in the Rock River basin, Wisconsin: U.S. Geological Survey Water-Resources Investigations Report 83-4186, 21 p.

Duerk, M.D., 1983, Automatic dilution gaging of rapidly varying flow: U.S. Geological Survey Water-Resources Investigations Report $83-4088,17 \mathrm{p}$.

Kammerer, P.A., Jr., Lidwin, R.A., Mason, J.W., and Narf, R.P., 1983, Aquatic biology in Nederlo Creek, southwestern Wisconsin: U.S. Geological Survey Water Resources Investigations 82-56, 27 p. 
Lawrence, C.L., and Ellefson, B.R., 1982, Water use in Wisconsin, 1979: U.S. Geological Survey Water-Resources Investigations $82-444,98 \mathrm{p}$.

Wentz, Dennis A., and Graczyk, David J., 1982, Effects of a floodwater-retarding structure on the hydrology and ecology of Trout Creek in southwestern Wisconsin: U.S. Geological Survey Water-Resources Investigations $82-23,68 \mathrm{p}$.

Holmstrom, B.K., 1982, Low-flow characteristics of streams in the Lake Michigan basin, Wisconsin: U.S. Geological Survey WaterResources Investigations Open-File Report 81-1193, 102 p.

House, Leo B., 1981, An assessment of streamflow, water quality, and the effects of construction on impoundment on Bridge Creek at Augusta, Wisconsin: U.S. Geological Survey Water-Resources Investigations Open-File Report 81-1192, 25 p.

Field, S.J., and Lidwin, R.A., 1982, Water-quality assessment of Steiner Branch basin, Lafayette County, Wisconsin: U.S Geological Survey Water-Resources Investigations 81-52, $58 \mathrm{p}$.

Gebert, W.A., 1982, Low-flow characteristics of streams in the Central Wisconsin River basin, Wisconsin: U.S. Geological Survey Water-Resources Investigations Open-File Report 81-495, 99 p.

Conger, Duane H., 1981, Techniques for estimating magnitude and frequency of floods for Wisconsin streams: U.S. Geological Survey Water-Resources Investigations Open-File Report 80$1214,116 \mathrm{p}$.

Krug, William R., and House, Leo B., 1980, Streamflow model of Wisconsin River for estimating flood frequency and volume: U.S. Geological Survey Water-Resources Investigations 80-1103, 44 p

Holmstrom, B.K., 1980, Low-flow characteristics of streams in the Menominee-Oconto-Peshtigo River basin, Wisconsin: WaterResources Investigations Open-File Report 80-749, 82 p.

1980, Low-flow characteristics of streams in the St. Croix River basin, Wisconsin: U.S. Geological Survey Water-Resources Investigations Open-File Report 80-696, 62 p.

Gebert, W.A., 1980, Low-flow characteristics of streams in the upper Wisconsin River basin, Wisconsin: U.S. Geological Survey Water-Resources Investigations Open-File Report 80-691, 60 p.

Krug, William R., 1981, Hydrologic effects of proposed changes in management practices, Winnebago Pool, Wisconsin: U.S. Geological Survey Water-Resources Investigations 80-107, 19 p.

House, Leo B., and Skavroneck, Steven, 1981, Comparison of the propane-area tracer method and predictive equations for determination of stream-reaeration coefficients on two small streams in Wisconsin: U.S. Geological Survey Water-Resources Investigations $80-105,18 \mathrm{p}$.

Kontis, A.L., and Mandle, R.J., 1980, Data-base system for northern Midwest regional aquifer-system analysis: U.S. Geological Survey Water-Resources Investigations 80-104, 27 p.

Grant, R.S., and Goddard, Gerald, 1980, Channel erosion and sediment transport in Pheasant Branch basin near Middleton, Wisconsin, a preliminary report: U.S. Geological Survey Water-Resources Investigations Open-File Report 80-161, 19 p., 11 figs., 3 tables.

McLeod, R.S., 1980, The effects of using ground water to maintain water levels of Cedar Lake, Wisconsin: U.S. Geological Survey Water-Resources Investigations $80-23,35 \mathrm{p}$.

Grant, R.S., and Skavroneck, Steven, 1980, Comparison of tracer methods and predictive models for determination of stream-reaeration coefficients on three small streams in Wisconsin: U.S. Geological Survey Water-Resources Investigations 80-19, $36 \mathrm{p}$.

Hindall, S.M., 1979, Ground-water quality in selected areas of Wisconsin: U.S. Geological Survey Water-Resources Investigations Open-File Report 79-1594, 20 p.

Stedfast, D.A., 1979, Low-flow characteristics of streams in the Pecatonica-Sugar River basin, Wisconsin: U.S. Geological Survey Water-Resources Investigations Open-File Report 79$1274,92 \mathrm{p}$.

Grant, R.S., and Goddard, Gerald, 1979, Urban storm-runoff modeling-Madison, Wisconsin: U.S. Geological Survey WaterResources Investigations Open-File Report 79-1273, 20 p.

Novitzki, R.P., and Holmstrom, B.K., 1979, Monthly and annual water budgets of Lake Wingra, Madison, Wisconsin, 1971-77: U.S. Geological Survey Water-Resources Investigations 79-100, 31 p.

Kammerer, P.A., and Sherrill, M.G., 1979, Hydrology and water quality in the Nederlo Creek basin before construction of two waterretention structures: U.S. Geological Survey Water-Resources Investigations $79-95,42 \mathrm{p}$.

Gebert, W.A., 1979, Low-flow characteristics of streams in Lake Superior basin, Wisconsin: U.S. Geological Survey WaterResources Investigations 79-38, $74 \mathrm{p}$.

Holmstrom, B.K., 1979, Low-flow characteristics of Wisconsin streams at sewage-treatment plants and industrial plants: U.S. Geological Survey Water-Resources Investigations 79-31, 123 p.

Gebert, W.A., 1979, Red Cedar River basin, Wisconsin: Low-flow characteristics: U.S. Geological Survey Water-Resources Investigations $79-29,12 \mathrm{p}$.

Holmstrom, B.K., 1979, Low-flow characteristics of streams in the Trempealeau-Black River basin, Wisconsin: U.S. Geological Survey Water-Resources Investigations 79-9, 79 p.

Sherrill, M.G., 1979, Contamination potential in the Silurian dolomite aquifer, eastern Wisconsin: U.S. Geological Survey WaterResources Investigations 78-108, 2 pls.

Holmstrom, B.K., 1978, Low-flow characteristics of streams in the Rock-Fox River basin, Wisconsin: U.S. Geological Survey Water-Resources Investigations 78-85, $98 \mathrm{p}$.

Rathbun, R.E., and Grant, R.S., 1978, Comparison of the radioactive and modified techniques for measurement of stream reaeration coefficients: U.S. Geological Survey Water-Resources Investigations $78-68,65 \mathrm{p}$.

Field, S.J., 1978, Ten-year low mean monthly discharge determinations for ungaged streams near waste-stabilization ponds in Wisconsin: U.S. Geological Survey Water-Resources Investigations 78-49, $16 \mathrm{p}$.

Novitzki, R.P., 1978, Hydrology of the Nevin wetland near Madison, Wisconsin: U.S. Geological Survey Water-Resources Investigations $78-48,25$ p.

Grant, R.S., 1978, Reaeration capacity of the Rock River between Lake Koshkonong, Wisconsin, and Rockton, Illinois: U.S. Geological Survey Water-Resources Investigations 77-128, $33 \mathrm{p}$.

Gebert, W.A., 1978, Low-flow characteristics of streams in the lower Wisconsin River basin: U.S. Geological Survey Water-Resources Investigations $77-118,80 \mathrm{p}$. 
Gebert, W.A., and Holmstrom, B.K., 1977, Low-flow characteristics at gaging stations on the Wisconsin, Fox, and Wolf Rivers, Wisconsin: U.S. Geological Survey Water-Resources Investigations $77-27,20 \mathrm{p}$.

Rose, W.J., 1977, Hydrologic considerations associated with dredging spring ponds in Wisconsin: U.S. Geological Survey WaterResources Investigations $77-18,35 \mathrm{p}$.

Krug, W.R., 1976, Simulation of streamflow of Flambeau River at Park Falls, Wisconsin, to define low-flow characteristics: U.S. Geological Survey Water-Resources Investigations 76-116, 14 p.

Grant, R.S., 1976, Reaeration of coefficient measurements of 10 small streams in Wisconsin using radioactive tracers- with a section on the energy-dissipation model: U.S. Geological Survey WaterResources Investigations 76-96, $50 \mathrm{p}$.

Novitzki, R.P., 1976, Recycling ground water in Waushara County, Wisconsin: Resource management for cold-water fish hatcheries: U.S. Geological Survey Water-Resources Investigations 76-20, $60 \mathrm{p}$.

Hindall, S.M., 1976, Measurement and prediction of sediment yields in Wisconsin streams: U.S. Geological Survey Water-Resources Investigations $54-75,27 \mathrm{p}$.

Oakes, E.L., Hendrickson, G.E., and Zuehls, E.E., 1975, Hydrology of the Lake Wingra basin, Dane County, Wisconsin: U.S. Geological Survey Water-Resources Investigations 17-75, 31 p.

Gebert, W.A., and Holmstrom, B.K., 1974, Low-flow characteristics of Wisconsin streams at sewage-treatment plants: U.S. Geological Survey Water-Resources Investigations 45-74, 101 p.

Hendrickson, G.E., Knutilla, R.L., and Doonan, C.J., 1973, Hydrology and recreation of selected cold-water rivers of the St. Lawrence River basin in Michigan, New York, and Wisconsin: U.S. Geological Survey Water-Resources Investigations 8-73, 73 p.

\section{OPEN-FILE REPORTS}

Scudder, B.C., Selbig, J.W., and Waschbusch, R.J., 2000, Determination of the effects of fine-grained sediment and other limiting variables on trout habitat for selected streams in Wisconsin: U.S. Geological Survey Open-File Report 00-435, 25 p.

Maertz, D.E., 2000, Water-resources investgigations in Wisconsin: U.S. Geological Survey Open-File Report 00-251, $117 \mathrm{p}$

Corsi, S.R., Greb, S.R., Bannerman, R.T., and Pitt, R.E., 1999, Evaluation of the multi-chambered treatment train, a retrofit water-quality management device: U.S. Geological Survey Open-File Report 99-270, 24 p.

Maertz, D.E., 1999, Water-resources investigations in Wisconsin, 1999: U.S. Geological Survey Open-File Report 99-229, 112 p.

Wisconsin District Lake-Studies Team, 1999, Water-quality and lakestage data for Wisconsin lakes, water year 1998: U.S. Geological Survey Open-File Report 99-98, 143 p

Krug, W. R., 1999, Simulation of the effects of operating Lakes Mendota, Monona, and Waubesa, south-central Wisconsin, as multipurpose reservoirs to maintain dry-weather flow: U.S. Geological Survey Open-File Report 99-67, 18 p.

Hall, D.W., Behrendt, T.E., and Hughes, P.E., 1998, temperature, pH, conductance, and dissolved oxygen in cross sections of 11 Lake Michigan tributaries, 1994-95: U.S. Geological Survey OpenFile Report 98-567, 85 p.
Maertz, D.E., 1998, Water-resources investigations in Wisconsin: U.S. Geological Survey Open-File Report 98-295, 96p.

Wisconsin District Lake-Studies Team, 1998, Water-quality and lakestage data for Wisconsin lakes, water year 1997: U.S. Geological Survey Open-File Report 98-78, 129 p.

Ellefson, B.R., Fan, C.H., and Ripley, J.L., 1997, Water use in Wisconsin, 1995: U.S. Geological Survey Open-File Report 97-356, 1 sheet.

Maertz, D.E., 1997, Water-resources investigations in Wisconsin, U.S. Geological Survey Open-File Report 97-351, 91 p.

Wisconsin District Lake-Studies Team, 1997, Water-quality and lakestage data for Wisconsin lakes, water year 1996: U.S. Geological Survey Open-File Report 97-123, 134 p.

Rappold, K.F., Wierl, J.A., and Amerson, F.U., 1997, Watershed characteristics and land management in the nonpoint-source evaluation monitoring watersheds in Wisconsin: U.S. Geological Survey Open-File Report 97-119, 39 p.

Owens, D.W., Corsi, S.R., and Rappold, K.F., 1997, Evaluation of nonpoint-source contamination, Wisconsin: Selected topics for water year 1995: U.S. Geological Survey Open-File Report 96-661A, $41 \mathrm{p}$.

Bannerman, Roger T., Legg, Andrew D., and Greb, Steven R., 1996, Quality of Wisconsin stormwater 1989-94: U.S. Geological Survey Open-File Report 96-458, 26 p.

Maertz, D.E., 1996, Water-resources investigations in Wisconsin, U.S. Geological Survey Open-File Report 96-333, 74 p.

Wisconsin District Lake-Studies Team, 1996, Water-quality and lakestage data for Wisconsin lakes, water year 1995: U.S. Geological Survey Open-File Report 96-168, 123 p.

Wierl, J.A., Rappold, K.F., and Amerson, F.U., 1996, Summary of the land-use inventory for the nonpoint-source evaluation monitoring watersheds in Wisconsin: U.S. Geological Survey Open-File Report 96-123, $23 \mathrm{p}$.

Steuer, J.J., Selbig, W.R. and Hornewer, N.J., 1996, Contaminant concentrations in stormwater from eight Lake Superior basin cities, 1993-94: U.S. Geological Survey Open-File Report 96-122, $16 \mathrm{p}$.

Waschbusch, R.J., 1996, Stormwater-runoff data, Madison, Wisconsin, 1993-94: U.S. Geological Survey Open-File Report 95-733, $33 \mathrm{p}$.

Maertz, D.E., 1995, Water-resources investigations in Wisconsin, 1995: U.S. Geological Survey Open-File Report 95-328, 84 p.

Walker, J.R., Graczyk, D.J., Corsi, S.R., Owens, D.W., and Wierl, J.A., 1995, Evaluation of nonpoint-source contamination, Wisconsin: Land-use and best-management-practices inventory, selected streamwater-quality data, urban-watershed quality assurance and quality control, constituent loads in rural streams, and snowmeltrunoff analysis, water year 1994: U.S. Geological Survey OpenFile Report 95-320, 21 p.

Wisconsin District Lake-Studies Team, 1995, Water-quality and lakestage data for Wisconsin lakes, water year 1994: U.S. Geological Survey Open-File Report 95-190, 157 p.

Peters, C.A., 1995, National Water-Quality Assessment Program, Western Lake Michigan Drainages-Summaries of Liaison Committee Meeting, Green Bay, Wisconsin, March 28-29, 1995: U.S. Geological Survey Open-File Report 95-163, 57 p. 
Corsi, S.R., Walker, J.F., Graczyk, D.J., Greb, S.R., Owens, D.W., and Rappold, K.F., 1995, Evaluation of nonpoint-source contamination, Wisconsin: Selected streamwater-quality data, land-use and best-management practices inventory, and quality assurance and quality control, water year 1993: U.S. Geological Survey OpenFile Report 94-707, $57 \mathrm{p}$

Krohelski, J.T., and Batten, W.G., 1995, Simulation of stage and the hydrologic budget of Devils Lake, Sauk County, Wisconsin: U.S. Geological Survey Open-File Report 94-348, 22 p.

House, Leo B., 1995, Distribution and transport of polychlorinated biphenyls in Little Lake Butte des Morts, Fox River, Wisconsin, April 1987-October 1988: U.S. Geological Survey Open-File Report 93-31, 43 p., 1 pl.

Maertz, D.E., 1994, Water-resources investigations in Wisconsin, 1994: U.S. Geological Survey Open-File Report 94-321.

Graczyk, D.J., Walker, J.F., Greb, S.R., Corsi, S.R., and Owens, D.W., 1993, Evaluation of nonpoint-source contamination, Wisconsin: Selected data for 1992 water year: U.S. Geological Survey OpenFile Report 93-630, 48 p.

House, Leo B., Waschbusch, Robert J., and Hughes, Peter E., 1993, Water quality of an urban wet detention pond in Madison, Wisconsin, 1987-88: U.S. Geological Survey Open-File Report 93-172, $57 \mathrm{p}$.

House, L.B., Hughes, P.E., and Waschbusch, R.J., 1993, Concentrations and loads of polychlorinated biphenyls in major tributaries entering Green Bay, Lake Michigan, 1989-90: U.S. Geological Survey Open-File Report 93-132, 41 p.

Walker, John F., 1993, Techniques for detecting effects of urban and rural land-use practices on stream-water chemistry in selected watersheds in Texas, Minnesota, and Illinois: U.S. Geological Survey Open-File Report 93-130, 16 p.

Maertz, D.E., 1993, Water-resources investigations in Wisconsin, 1993: U.S. Geological Survey Open-File Report 93-129, 91 p.

Ellefson, B.R., Sabin, T.J., and Krohelski, J.T., 1993, Water use in Wisconsin, 1990: U.S. Geological Survey Open-File Report 93118,1 sheet

Maertz, D.E., 1992, Water-resources investigations in Wisconsin: Programs and activities of the U.S. Geological Survey, 19911992: U.S. Geological Survey Open-File Report 92-125, 93 p.

Elder, J.F., Krabbenhoft, D.P, and Walker, J.F., 1992, Water, energy, and biogeochemical budgets (WEBB) program: Data availability and research at the northern temperate lakes site, Wisconsin: U.S. Geological Survey Open-File Report 92-48, 15 p.

Krabbenhoft, D.P., and Krohelski, J.T., 1992, Data on water quality, lake sediment, and lake-level fluctuation, St. Croix Indian Reservation, Wisconsin, 1981-87: U.S. Geological Survey Open-File Report 92-26, $53 \mathrm{p}$.

Hughes, P.E., 1993, Hydrologic and water-quality data for the East River Basin of northeastern Wisconsin: U.S. Geological Survey Open-File Report 89-245, 91 p.

Setmire, J.G., 1991, National Water-Quality Assessment Program Western Lake Michigan Drainage Basin: U.S. Geological Survey Open-File Report 91-161, Water Fact Sheet, 2 p.

Melcher, N.B. and Walker, J.F., 1990, Evaluation of selected methods for determining streamflow during periods of ice effect: U.S. Geological Survey Open-File Report 90-554, 51 p.
U.S. Geological Survey, 1990, The effects of the 1988 drought on the water resources of Wisconsin: U.S. Geological Survey Open-File Report 90-149, Water Fact Sheet, 2 p.

House, L.B., 1990, Data on polychlorinated biphenyls, dieldrin, lead, and cadmium in Wisconsin and upper Michigan tributaries to Green Bay, July 1987 through April 1988: U.S. Geological Survey Open-File Report 89-52, 11 p.

Gebert, Warren A., Graczyk, David J., and Krug, William R., 1988, Runoff for selected sites in Shenandoah National Park, Virginia, July 18, 1981 through July 17, 1982: U.S. Geological Survey Open-File Report 88-98, 13 p.

Ellefson, B.R., Rury, Kraig S., and Krohelski, James T., 1988, Water use in Wisconsin, 1985: U.S. Geological Survey Open-File Report 87-699.

Krug, W.R., Gebert, W.A., and Graczyk, D.J., 1989, Preparation of average annual runoff map of the United States, 1951-80: U.S. Geological Survey Open-File Report 87-535, 414 p.

Krug, William R., Ostenso, Nile A., and Krohelski, James T., 1988, Prediction of the effects of mine dewatering on four lakes near Crandon, Wisconsin, by use of a water-budget model: U.S Geological Survey Open-File Report 87-471, 63 p.

Graczyk, David J., Gebert, Warren A., Krug, William R., and Allord, G.J., 1987, Maps of runoff in the Northeastern Region and southern Blue Ridge Province of the United States during selected time periods in 1983-85: U.S. Geological Survey Open-File Report 87-106, 8 p., 3 pl.

Graczyk, David J., Krug, William R., and Gebert, Warren A., 1986, A history of annual streamflows from the 21 water-resource regions in the United States and Puerto Rico, 1951-83: U.S. Geological Survey Open-File Report 86-128, 30 p.

Henrich, E.W., 1984, Drainage area data for Wisconsin Streams: U.S Geological Survey Open-File Report 83-933, 322 p

Lawrence, C.L., Ellefson, B.R., and Cotter, R.D., 1984, Public-supply pumpage in Wisconsin in 1979: U.S. Geological Survey OpenFile Report 83-931, $40 \mathrm{p}$

Lawrence, C.L., and Ellefson, B.R., Water use in Wisconsin, 1979 U.S. Geological Survey Open-File Report 82-444, 98 p.

Novitzki, R.P., 1979, Streamflow estimates in selected Wisconsin streams: U.S. Geological Survey Open-File Report 79-1282, $11 \mathrm{p}$.

Harr, C.A., and Novitzki, R.P., 1979, Availability of supplemental water supplies at salmonid fish-propagation stations in Wisconsin: U.S. Geological Survey Open-File Report 79-1170, 13 p.

Krug, W.R., 1979, Simulation of streamflow of Rock River at Lake Koshkonong, Wisconsin, to determine effects of withdrawal of powerplant-cooling water: U.S. Geological Survey Open-File Report 79-253, $21 \mathrm{p}$.

McLeod, R.S., 1978, Water-level declines in the Madison area, Dane County, Wisconsin: U.S. Geological Survey Open-File Report 78-936, $15 \mathrm{p}$.

Field, S.J., 1978, Low-flow characteristics of small streams in proposed Public Law 566 basins: U.S. Geological Survey Open-File Report 78-664, 32 p.

Hindall, S.M., 1978, Suspended-sediment transport in the Big Eau Pleine River basin, central Wisconsin: U.S. Geological Survey Open-File Report 78-313, 12 p. 
Lawrence, C.L., 1976, Regional flood limits of lower Yahara River, Lake Waubesa and south, in Dane County, Wisconsin: U.S. Geological Survey Open-File Report 76-805, 20 p.

Krug, W.R., 1976, Probable maximum flood at Lake Chippewa near Winter, Wisconsin: U.S. Geological Survey Open-File Report $76-800,14 \mathrm{p}$.

Grant, R.S., 1976, Waste-assimilation study of Koshkonong Creek below sewage-treatment plant at Sun Prairie, Wisconsin: U.S. Geological Survey Open-File Report 76-655, 44 p.

Lawrence, C.L., 1976, Regional flood limits of upper Yahara River in Dane County, Wisconsin: U.S. Geological Survey Open-File Report 76-448, 15 p.

Holmstrom, B.K., 1976, Low-flow characteristics and mean annual discharge of North Branch Manitowoc River at Potter, Wisconsin: U.S. Geological Survey Open-File Report 76-204, $20 \mathrm{p}$.

Krug, W.R., 1976, Flood-plain delineation for regional flood in Dane County, Wisconsin: U.S. Geological Survey Open-File Report $76-164,168 \mathrm{p}$.

Field, S.J., 1975, Low-flow study of the Pike River basin, Racine and Kenosha Counties, Wisconsin: U.S. Geological Survey OpenFile Report 75-653, $10 \mathrm{p}$.

Green, J.H., 1975, Flow characteristics of the lower Wisconsin River: U.S. Geological Survey Open-File Report 75-582, 9 p.

Holmstrom, B.K., 1975, Streamflow characteristics of Klawitter Creek basin near Westfield, Wisconsin: U.S. Geological Survey OpenFile Report 75-527, 14 p.

Krug, W.R., 1975, Analysis of operational plan for Lake Chippewa near Winter, Wisconsin: U.S. Geological Survey Open-File Report 75-487, 17 p.

Holmstrom, B.K., 1975, Low-flow characteristics of the Eau Claire River basin near Antigo, Wisconsin: U.S. Geological Survey Open-File Report 75-336, 19 p.

Gebert, W.A., 1974, Streamflow characteristics of Little Wolf RiverHolt Creek basin near Galloway, Wisconsin: U.S. Geological Survey Open-File Report, $10 \mathrm{p}$.

Lawrence, C.L., and Holmstrom, B.K., 1973, Floods on Yahara River tributaries, Dane County, Wisconsin: U.S. Geological Survey Open-File Report, 19 p.

Grant, R.S., Krug, W.R., and Duerk, M.D., 1973, Floodplain and floodway delineation for regional flood in central Marathon County, Wisconsin: U.S. Geological Survey Open-File Report, 33 p.

Holmstrom, B.K., Gebert, W.A., and Borman, R.G., 1973, Alder Creek hydrology, Wisconsin: U.S. Geological Survey Open-File Report, $28 \mathrm{p}$.

Lawrence, C.L., and Holmstrom, B.K., 1972, Flood in Starkweather Creek basin, Madison, Wisconsin: U.S. Geological Survey OpenFile Report, 15 p.

Holmstrom, B.K., 1972, Drainage-area data for Wisconsin streams: U.S. Geological Survey Open-File Report, 74 p. (Updated 1973, 1974, 1978, and 1979.)

Hindall, S.M., 1972, Sediment yields of Wisconsin streams: U.S. Geological Survey Open-File Report, 2 p.

Weeks, E.P., and Stangland, H.G., 1971, Effects of irrigation on streamflow in the central sand plains of Wisconsin: U.S. Geological Survey Open-File Report, 113 p.
Conger, D.H., 1971, Estimating magnitude and frequency of floods in Wisconsin: U.S. Geological Survey Open-File Report, 200 p.

Holmstrom, B.K., and Lawrence, C.L., 1971, Floods on Yahara River, Lake Mendota to Lake Kegonsa, Dane County, Wisconsin: U.S. Geological Survey Open-File Report, 12 p.

Lawrence, C.L., and Holmstrom, B.K., 1971, Floods on Yahara River, Lake Kegonsa dam to countyline, Dane County, Wisconsin: U.S. Geological Survey Open-File Report, 10 p.

Shearman, J.O., and Lawrence, C.L., 1971, Floods on Yahara River upstream from Lake Mendota, Dane County, Wisconsin: U.S. Geological Survey Open-File Report, 7 p.

Gebert, W.A., 1971, Hydrology of Pine Creek: U.S. Geological Survey Open-File Report, 6 p.

1971, Hulbert Creek hydrology, southwestern Wisconsin: U.S. Geological Survey Open-File Report, 11 p.

Gonthier, J.B., 1970, Water resources of southeastern WisconsinMilwaukee River basin: U.S. Geological Survey Open-File Report, 138 p. (Extensively used in preparation of "A comprehensive plan for the Milwaukee River watershed", v. 1 and 2, 1970 and 1971, Southeastern Wisconsin Regional Planning Commission Report No. 13, v. 1, 514 p. and v. 2, 623 p.)

Hamilton, L.J., 1970, Availability of ground water in the lower Wisconsin River Valley, Wisconsin: U.S. Geological Survey Open-File Report, 45 p.

Campbell, R.E., and Dreher, F.C., 1970, A proposed stream-flow data program for Wisconsin: U.S. Geological Survey Open-File Report, 55 p.

Shearman, J.O., 1969, Evaluation of flood potential, part 2 of Floodplain management-Lake Koshkonong: U.S. Geological Survey Open-File Report, 6 p.

Young, K.B., 1965, Effect of treated effluent diversion on Yahara River flow: U.S. Geological Survey Open-File Report, 81 p.

1965 , Supplement to report on flow characteristics of Wisconsin streams: U.S. Geological Survey Open-File Report, 81 p.

U.S. Geological Survey, 1964, Water-quality records in Michigan and Wisconsin: U.S. Geological Survey Open-File Report, 61 p.

Young, K.B., 1963, Flow characteristics of Wisconsin streams: U.S. Geological Survey Open-File Report, 151 p.

Erickson, D.W., 1961, Floods in Wisconsin, magnitude and frequency: U.S. Geological Survey Open-File Report, 109 p.

1961, Wisconsin River near Dekorra, Wisconsin, flood-flow characteristics at proposed bridge site on the Wisconsin Freeway in Columbia County: U.S. Geological Survey Open-File Report, $13 \mathrm{p}$.

Spicer, H.C., and Edwards, G.J., 1955, Electrical resistivity measurements in the Neillsville area. Wisconsin: U.S. Geological Survey Open-File Report, 34 p.

1954, A resistivity survey to locate an aquifer in the glacial deposits near Marshfield, Wisconsin: U.S. Geological Survey Open-File Report, 76 p.

Drescher, W.J., 1948, Results of pumping tests on artesian wells in the Milwaukee-Waukesha area, Wisconsin: U.S. Geological Survey Open-File Report, 22 p. 


\section{OPEN-FILE MAPS}

Gonthier, J.B., 1979, Water-table map of Waukesha County, Wisconsin: U.S. Geological Survey Water-Resources Investigations Open-File Map 79-43, 1 pl.

Sherrill, M.G., and Erickson, J.R., 1979, Water-table map of Walworth County, Wisconsin: U.S. Geological Survey Water-Resources Investigations Open-File Map 79-42, 1 pl.

Sherrill, M.G., and Schiller, J.J., 1979, Water-table map of Racine County, Wisconsin: U.S. Geological Survey Water-Resources Investigations Open-File Map 79-41, 1 pl.

Sherrill, M.G., Schiller, J.J., and Erickson, J.R., 1979, Water-table map of Milwaukee County, Wisconsin: U.S. Geological Survey Water-Resources Investigations Open-File Map 79-40, 1 pl.

Sherrill, M.G., and Schiller, J.J., 1979, Water-table map of Kenosha County, Wisconsin: U.S. Geological Survey Water-Resources Investigations Open-File Map 79-39, 1 pl.

Borman, R.G., 1976, Thickness of unconsolidated materials of Walworth County, Wisconsin: U.S. Geological Survey OpenFile Report 76-465, scale 1:62,500.

1976, Water-table map of Walworth County, Wisconsin: U.S. Geological Survey Open-File Report 76-464, scale 1:62,500.

1976, Bedrock topography of Walworth County, Wisconsin: U.S. Geological Survey Open-File Report 76-463, scale $1: 62,500$.

1976, Bedrock geology of Walworth County, Wisconsin: U.S. Geological Survey Open-File Report 75-462, scale 1:62,500.

Gonthier, J.B., 1975, Bedrock topography of Waukesha County, Wisconsin: U.S. Geological Survey Open-File Report 75-572, scale $1: 62,500$.

1975, Water-table map of Waukesha County, Wisconsin: U.S. Geological Survey Open-File Report 75-571, scale 1:62,500.

1975, Bedrock geology of Waukesha County, Wisconsin: U.S. Geological Survey Open-File Report 75-570, scale 1:62,500.

Borman, R.G., 1971, Preliminary map showing thickness of glacial deposits in Wisconsin: U.S. Geological Survey Open-File Report, scale $1: 2,500,000$.

1971, Preliminary map of probable well yields from bedrock in Wisconsin: U.S. Geological Survey Open-File Report, scale $1: 2,500,000$.

1971, Preliminary map of probable well yields from glacial deposits in Wisconsin: U.S. Geological Survey Open-File Report, scale $1: 2,500,000$.

\section{ADMINISTRATIVE REPORTS}

Rose, W.J., 1979, Bedload in northwestern Wisconsin's Nemadji River: U.S. Geological Survey Administrative Report, 12 p.

Hindall, S.M., and Graczyk, D.J., 1978, St. Croix National Scenic Riverway flood-plain delineation and water quality monitoring: U.S. Geological Survey Administrative Report, 47 p.

Kammerer, P.A., and Lidwin, R.A., 1977, Water quality in the Pine River basin Richland and Vernon Counties, Wisconsin: U.S. Geological Survey Administrative Report, 93 p.
Novitzki, R.P., 1971, Hydrologic investigations of Heart Lake, Green Lake County, Wisconsin: U.S. Geological Survey Administrative Report, 9 p.

1971, Hydrologic investigations for the Woodruff Fish Hatchery, Oneida County, Wisconsin: U.S. Geological Survey Administrative Report, $4 \mathrm{p}$.

1971, Hydrologic investigations of a proposed reservoir site in Trempealeau County, Wisconsin: U.S. Geological Survey Administrative Report, 4 p.

\section{FACT SHEETS}

Elder, J.F., and Robertson, D.M., 2000, Chemical composition of surficial sediment in Geneva Lake, Wisconsin: U.S. Geological Survey Fact Sheet 121-00, 4 p.

Owens, D.W., Jopke, P., Hall, D.W., Balousek, J., and Roa, A., 2000, Soil erosion from two small construction sites, Dane County, Wisconsin: U.S. Geological Survey Fact Sheet 109-00, 4 p.

Hunt, Randall J., Graczyk, David J., and Rose, William J., 2000, Water flows in the Necedah National Wildlife Refuge: U.S. Geological Survey Fact Sheet 068-00, 4 p.

Graczyk, David J., Robertson, Dale M., Rose, William J., and Steuer, Jeffrey J., 2000, Comparison of water-quality samples collected by siphon samplers and automatic samplers in Wisconsin: U.S. Geological Survey Fact Sheet 067-00, 4 p.

Graczyk, D.J., Vanden Brook, J.P., and Rheineck, B.D., 1999, Herbicides in the Pecatonica, Trempealeau, and Yahara Rivers in Wisconsin, May 1997-July 1998: U.S. Geological Survey Fact Sheet $167-99,9 \mathrm{p}$.

Wierl, Judy A., Giddings, Elise, M.P., and Bannerman, Roger T., 1998, Evaluation of a method for comparing phosphorus loads from barnyards and croplands in Otter Creek watershed, Wisconsin: U.S. Geological Survey Fact Sheet 168-98, 4 p.

Rose, W.J., and Robertson, D.M., 1998, Hydrology, water quality, and phosphorus loading of Kirby Lake, Barron County, Wisconsin: U.S. Geological Survey Fact Sheet 066-98, 4 p.

Stuntebeck, Todd D., and Bannerman, Roger T., 1998, Effectiveness of barnyard best management practices in Wisconsin: U.S. Geological Survey Fact Sheet 051-98, 4 p.

Team for evaluating the Wisconsin Water-Monitoring Network, 1998, Plan for an integrated long-term water-monitoring network for Wisconsin: U.S. Geological Survey Fact Sheet 048-98, 4 p.

Corsi, Steven R., Graczyk, David J., Owens, David W., and Bannerman, Roger T., 1997, Unit-area loads of suspended sediment, suspended solids, and total phosphorus from small watersheds in Wisconsin: U.S. Geological Survey Fact Sheet 195-97, 4 p.

Graczyk, David J., and Vanden Brook, James P., 1997, Herbicides in the Pecatonica and Yahara Rivers in southwestern Wisconsin, May 1996-July 1996: U.S. Geological Survey Fact Sheet 175-97, $4 \mathrm{p}$.

Lenz, Bernard N., 1997, Feasibility of combining two aquatic benthic macroinvertebrate community databases for water-quality assessment: U.S. Geological Survey Fact Sheet 132-97, 4 p.

Hunt, Randall J., 1996, Do created wetlands replace the wetlands that are destroyed: U.S. Geological Survey Fact Sheet 246-96, 4 p. 
Elder, John F., and Goddard, Gerald L., 1996, Sediment and nutrient trapping efficiency of a constructed wetland near Delavan Lake, Wisconsin, 1993-1995: U.S. Geological Survey Fact Sheet 23296, 4 p.

Kammerer, P.A., Jr., 1996, Hydrology and water quality of Park Lake, South-Central Wisconsin: U.S. Geological Survey Fact Sheet $197-96,4 \mathrm{p}$.

Matzen, Amy M., and Saad, David A., 1996, Pesticides in ground water in the Western Lake Michigan drainages, Wisconsin and Michigan, 1983-1995: U.S. Geological Survey Fact Sheet 192-96, 4 p.

U.S. Geological Survey, 1996, Real-time streamflow conditions: U.S. Geological Survey Fact Sheet 190-96, 2 p.

Krabbenhoft, David P., 1996, Mercury studies in the Florida Everglades: U.S. Geological Survey Fact Sheet 166-96, 4 p.

Fitzgerald, Sharon A., and Steuer, Jeffrey J., 1996, The Fox River PCB transport study - stepping stone to a healthy Great Lakes ecosystem: U.S. Geological Survey Fact Sheet 116-96, 4 p.

Sullivan, Daniel J., and Richards, Kevin D., 1996, Pesticides in streams in the Western Lake Michigan drainages, Wisconsin and Michigan, 1993-95: U.S. Geological Survey Fact Sheet 107-96, 4 p.

Stuntebeck, Todd D., 1995, Evaluating barnyard best management practices in Wisconsin using upstream-downstream monitoring: U.S. Geological Survey Fact Sheet 221-95, 4 p.

Robertson, Dale M., and Saad, David A., 1995, Environmental factors used to subdivide the Western Lake Michigan Drainages into relatively homogeneous units for water-quality site selection: U.S. Geological Survey Fact Sheet 220-95, 4 p.

Krabbenhoft, D.P., and Rickert, D.A., 1995, Mercury contamination of aquatic ecosystems: U.S. Geological Survey Fact Sheet 216-95, 4 p.

Saad, David A., 1995, Nitrate in ground water in the Western Lake Michigan Drainage Basin, Wisconsin and Michigan: U.S. Geological Survey Fact Sheet 070-94, 2 p.

\section{WISCONSIN GEOLOGICAL AND NATURAL HISTORY SURVEY INFORMATION CIRCULARS}

Batten, W.G., 1989, Hydrogeology of Wood County, Wisconsin: Wisconsin Geological and Natural History Survey Information Circular 60, 27 p., 2 pls.

Patterson, G.L., and Zaporozec, Alexander, 1988, Analysis of waterlevel fluctuations in Wisconsin wells: Wisconsin Geological and Natural History Survey Information Circular 63, 38 p.

Batten, W.G., 1987, Water resources of Langlade County, Wisconsin: Wisconsin Geological and Natural History Survey Information Circular 58, 28 p., 1 pl.

Krohelski, J.T., 1986, Hydrogeology and ground-water use and quality, Brown County, Wisconsin: Wisconsin Geological and Natural History Survey Information Circular 57, $42 \mathrm{p}$.

House, L.B., 1986, Stage fluctuations of Wisconsin Lakes: Wisconsin Geological and Natural History Survey Information Circular No. 49, 84 p.

Devaul, R.W., Harr, C.A., and Schiller, J.J., 1983, Ground-water resources and geology of Dodge County, Wisconsin: Wisconsin Geological and Natural History Survey Information Circular 44, $34 \mathrm{p}$.
Erickson, R.M., and Cotter, R.D., 1983, Trends in ground-water levels in Wisconsin through 1981: Wisconsin Geological and Natural History Survey Information Circular 43, 139 p.

Novitzki, R.P., 1982, Hydrology of Wisconsin Wetlands: Wisconsin Geological and Natural History Survey Information Circular 40, $22 \mathrm{p}$.

Kammerer, Phil A., Jr., Ground-water quality atlas of Wisconsin: Wisconsin Geological and Natural History Survey Information Circular 39, $39 \mathrm{p}$.

Young, H.L., and Batten, W.G., 1980, Ground-water resources and geology of Washington and Ozaukee Counties, Wisconsin: Wisconsin Geological and Natural History Survey Information Circular 38, $37 \mathrm{p}$.

Harr, C.A., Trotta, L.C., and Borman, R.G., 1978, Ground-water resources and geology of Columbia County, Wisconsin: Wisconsin Geological and Natural History Survey Information Circular 37, $30 \mathrm{p}$.

Hindall, S.M., 1978, Effects of irrigation on water quality in the sand plain of central Wisconsin: Wisconsin Geological and Natural History Survey Information Circular 36, $50 \mathrm{p}$.

Borman, R.G., 1976, Ground-water resources and geology of Walworth County, Wisconsin: Wisconsin Geological and Natural History Survey Information Circular 34, 45 p.

Borman, R.G., and Trotta, L.C., 1976, Ground-water resources and geology of Jefferson County, Wisconsin: Wisconsin Geological and Natural History Survey Information Circular 33, 31 p.

Borman, R.G., 1976, Ground-water resources and geology of St. Croix County, Wisconsin: Wisconsin Geological and Natural History Survey Information Circular 32, $30 \mathrm{p}$.

Bell, E.A., and Hindall, S.M., 1975, The availability of ground water for irrigation in the Rice Lake-Eau Claire area, Wisconsin: Wisconsin Geological and Natural History Survey Information Circular 31, 65 p.

McLeod, R.S., 1975, A digital-computer model for estimating hydrologic changes in the aquifer system in Dane County, Wisconsin: Wisconsin Geological and Natural History Survey Information Circular 30, 40 p.

Gonthier, J.B., 1975, Ground-water resources of Waukesha County, Wisconsin: Wisconsin Geological and Natural History Survey Information Circular 29, $47 \mathrm{p}$.

McLeod, R.S., 1975, A digital-computer model for estimating drawdown in the sandstone aquifer in Dane County, Wisconsin: Wisconsin Geological and Natural History Survey Information Circular 28, $91 \mathrm{p}$.

Holt, C.L.R., Jr., and Skinner, E.L., 1973, Ground-water quality in Wisconsin through 1972: Wisconsin Geological and Natural History Survey Information Circular 22, $148 \mathrm{p}$.

Erickson, R.M., 1972, Trends in ground-water levels in Wisconsin, 1967-71: Wisconsin Geological and Natural History Survey Information Circular 21, 40 p. (Supplement to Information Circular 9).

Holt, C.L.R., Jr., Cotter, R.D., Green, J.H., and Olcott, P.G., 1970, Hydrogeology of the Rock-Fox River basin of southeastern Wisconsin: Wisconsin Geological and Natural History Survey Information Circular 17, 47 p. (Prepared for the Annual Meeting of the Geological Society of America-Field Trip Guidebook). 
Devaul, R.W., 1967, Trends in ground-water levels in Wisconsin through 1966: Wisconsin Geological and Natural History Survey Information Circular 9, $109 \mathrm{p}$.

Ryling, R.W., 1961, A preliminary study of the distribution of saline water in the bedrock aquifers of eastern Wisconsin: Wisconsin Geological and Natural History Survey Information Circular 5, $23 \mathrm{p}$.

Drescher, W.J., 1956, Ground water in Wisconsin: Wisconsin Geological and Natural History Survey Information Circular 3, 37 p.

1955, Some effects of precipitation on ground water in Wisconsin: Wisconsin Geological and Natural History Survey Information Circular 1, $17 \mathrm{p}$.

\section{WISCONSIN GEOLOGICAL AND NATURAL HISTORY SURVEY MISCELLANEOUS PAPERS}

Patterson, G.L., 1989, Water resources of Vilas County, Wisconsin: Wisconsin Geological and Natural History Survey Miscellaneous Paper 89-1, 46 p.

\section{OTHER PUBLICATIONS}

Hunt, Randy and Zheng, Chunmiao, 1999, Newsletter: Debating complexity in modeling; Eos, Transactions, American Geophysical Union, v. 80, no. 3, p. 29.

Hunt, R.J., Walker, J.F., and Krabbenhoft, D.P., 1999, Characterizing hydrology and the importance of ground-water discharge in natural and constructed wetlands: Wetlands, no. 19, v. 2, p. 458-472.

Lathrop, R.C., Carpenter, S.R., and Robertson, D.M., 1999, Summer water clarity responses to phosphorus, Daphnia grazing, and internal mixing in Lake Mendota: Limnology and Oceanography, v. 44 , no. 1 , p. $137-146$.

Panuska, J.C., and Robertson, D.M., 1999, Estimating phosphorus concentrations following alum treatment using apparent settling velocities: Lakes and Reservoir Management, v. 15, no. 1, p. 28-38.

Cleckner, Lisa B., Garrison, Paul J., Hurley, James P., Olson, Mark L., and Krabbenhoft, David P., 1998, Trophic transfer of methyl mercury in the northern Florida Everglades: Biogeochemistry, v. 40 , p. $347-361$.

Hunt, R.J., Anderson, M.P., and Kelson, V.A., 1998, Improving a complex finite difference groundwater-flow model through the use of an analytic element screening model: Ground Water, v. 36, no. 6, p. 1011-1017.

Hunt, R.J., Bullen, T.D., Krabbenhoft, D.P., and Kendall, C., 1998, Using stable isotopes of water and strontium to investigate the hydrology of a natural and constructed wetland: Ground Water, v. 36 , no. 3 , p. $434-443$.

Hurley, James P., Krabbenhoft, David P., Cleckner, Lisa B., Olson, Mark L., Aiken, George R., and Rawlik Jr., Peter S., 1998, System controls on the aqueous distribution of mercury in the northern Florida Everglades: Biogeochemistry, v. 40, p. 293-311.

Krabbenhoft, David P., Gilmour, Cynthia C., Benoit, Janina M., Babiarz, Christopher L., Andren, Anders W., and Hurley, James P., 1998, Methyl mercury dynamics in littoral sediments of a temperate seepage lake: Canadian Journal of Fisheries and Aquatic Sciences, v. 55, no. 4, p. 835-844.

Krabbenhoft, David P., Hurley, James P., Olson, Mark L., and Cleckner, Lisa B., 1998, Diel variability of mercury phase and species distributions in the Florida Everglades: Biogeochemistry, v. 40, p. 311-325.
Peters, C.A., and others, 1998, Water-quality in the western Lake Michigan drainages, Wisconsin and Michigan, 1992-95: U.S. Geological Survey Circular 1156, $40 \mathrm{p}$.

Robertson, D.M., Elder, J.F., Goddard, G.L., and James, W.F., 1998, Dynamics in phosphorus retention in wetlands upstream of Delavan Lake, Wisconsin: Lakes and Reservoir Management, v. 14, no. 4 , p. 466-477.

Schindler, John E., and Krabbenhoft, David P., 1998, The hyporheic zone as a source of dissolved organic carbon and carbon gases to a temperate forested stream: Biogeochemistry, v. 43, p. 157-174.

Team for Evaluating the Wisconsin Water-Monitoring Network, 1998, An integrated water-monitoring network for Wisconsin: University of Wisconsin Water Resources Center Special Report WRC SR 98-01, $62 \mathrm{p}$.

Thorstenson, Donald C., Weeks, Edwin P., Haas, Herbert, Busenberg, Eurybiades, Plummer, L. Niel., and Peters, Charles A., 1998, Chemistry of unsaturated zone gases sampled in open boreholes at the crest of Yucca Mountain, Nevada: Data and basic concepts of chemical and physical processes in the mountain: Water Resources Research, v. 34, no. 6, p. 1507-1529.

Walker, J.F., and Krabbenhoft, D.P., 1998, Groundwater and surfacewater interactions in riparian and lake-dominated systems in McDonnell, J.J., and Kendall, C., eds., Isotopic tracers in catchment hydrology: Elsevier, Amsterdam, The Netherlands, p. 467-486.

Fitzgerald, S.A., and Steuer, J.J., 1997, Polychlorinated biphenyls (PCBs) as probes of biogeochemical processes in rivers, in Molecular Markers in Environmental Geochemistry, Eganhouse, R.P., ed.: American Chemical Sociey Symposium Series, p. 382397.

Fitzgerald, S.A., and Steuer, J.J., 1997, Polychlorinated biphenyls (PCBs) as probes of biogeochemical processes in rivers, American Chemical Society Annual Meeting, Orlando, Florida, August 1996.

Hornewer, N.J., Johnson, G.P., Robertson, D.M., and Hondzo, M., 1997, Field-scale tests for determining mixing patterns associated with coarse-bubble air diffuser configurations, Egan Quarry, Illinois, in Environmental and Coastal Hydraulics: Protecting the Aquatic Habitat, proceedings of the International Association of Hydraulic Research, San Francisco, CA, USA, p. 57-63.

Hunt, R.J., Krabbenhoft, D.P., and Anderson, M.P., 1997, Assessing hydrogeochemical heterogeneity in natural and constructed wetlands: Biochemistry, v. 39, p. 271-293.

Olson, M.L., Cleckner, LB., Hurley, J.P., Krabbenhoft, D.P., and Heelan, T.W., 1997, Resolution of matrix effects on analysis of total and methyl mercury in aqueous samples from the Florida Everglades: Fresenius Journal of Analytical Chemistry, v. 358, p. 392-396.

Robertson, D.M., 1997, Regionalized loads of sediment and phosphorus to Lakes Michigan and Superior - High flow and long-term average: Journal of Great Lakes Research, v. 23, p. 416-439.

Walker, J.F., and Wang, D., 1997, Measurement of flow under ice covers in North America: Journal of Hydraulic Engineering, v. 123, no. 11, p. 1037-1040.

Anderson, W.L., Robertson, D.M., and Magnuson, J.J., 1996, Evidence of recent warming and El Nino-related variation in ice breakup of Wisconsin lakes: Limnology and Oceanography, v. 41, p. 815821. 
Bullen, T.D., Krabbenhoft, D.P., and Kendall, C., 1996, Kinetic and mineralogic controls on the evolution of groundwater chemistry and ${ }^{87} \mathrm{Sr} /{ }^{86} \mathrm{Sr}$ in a sandy silicate aquifer, northern Wisconsin: Geochemica Cosomchemica Acta, v. 60, p. 1807-1821.

Elder, J.F., James, R.V., and Steuer, J.J., 1996, Mobility of 2,2',5,5'tetrachlorobiphenyl in model systems containing bottom sediments and water from an industrialized river basin in northeastern Wisconsin: Journal of Great Lakes Research, v. 22, no. 3, p. 697 . 706.

Gebert, Warren A. and Krug, William R., 1996, Streamflow trends in Wisconsin's driftless area: Journal of the American Water Resources Association, v. 32, no. 4, p. 733-744.

Hunt, R.J., Krabbenhoft, D.P., and Anderson, M.P., 1996, Groundwater inflow measurements in wetland systems: Water Resources Research, v. 32, no. 3, p. 495-507.

Hunt, R.J., and Krohelski, J.T., 1996, The application of an analytic element model to investigate ground-water lake interactions at Pretty Lake, Wisconsin: Journal of Lakes and Reservoir Management, v. 12 , no. 4 , p. $487-495$.

lmberger, J., Robertson, D.M., and Boland, K., 1996, Lake Number A quantitative indicator of mixing to be used in water quality management: Scientificlmpeller, Solna, Sweden, no. 4, p. 9-15.

Klump, J.V., Edgington, D.N., Sager, P.E., and Robertson, D.M., 1996, The bigeochemistry of Green Bay - 1. Sedimentary phosphorus cycling in a phosphorus mass balance for the Green Bay ecosystem: Canadian Journal of Fisheries and Aquatic Sciences, v. 54, no. 1 , p. 10-26.

Krug, William R., 1996, Simulation of temporal changes in rainfallrunoff characteristics, Coon Creek Basin, Wisconsin: Journal of the American Water Resources Association, v. 32, no. 4, p. 745 . 752 .

Assel, Raymond A., and Robertson, Dale M., 1995, Changes in winter air temperatures near Lake Michigan, 1851-1993, as determined from regional lake-ice records: limnology and Oceanography, v. 40 , no. 1 , January 1995 , p. $165-176$.

Assel, R.A., Robertson, D.M., Hoff, M.H., and Selgeby, J.H., 1995, Climatic-change implications from long-term (1823-1994) ice records near the Laurention Great Lakes: Annals of Glaciology, v. 21 , p. $383-386$.

Greb, Steven R., and Graczyk, David J., 1995, Frequency duration analysis of dissolved-oxygen concentrations in two southwestern Wisconsin streams: Water Resources Bulletin, American Water Resources Association, v. 31, no. 3, June 1995, p. 431-438.

Kendall, C., and Krabbenhoft, D.P., 1995, Applications of isotopes to tracing sources of solutes and water in shallow systems in Charbeneau, R.J., ed., Groundwater Management, proceedings of the international symposium, August 1995, San Antonio, Tx, American Association of Civil Engineers, p. 390-395.

Krabbenhoft, David P., Benoit, Janina M., Babiarz, Christopher L., Hurley, James P., and Andren, Anders W., 1995, Mercury cycling in the Allequash Creek watershed, northern Wisconsin: Water, Air, and Soil Pollution, v. 80, nos. 1/4, February 1995, p. 425433.

Krabbenhoft, David P., and Webster, Katherine E., 1995, Transient hydrogeological controls on the chemistry of a seepage lake: Water Resources Research, v. 31, no. 9, September 1995, p. 2295-2305.

Velleux, Mark, Endicott, Douglas, Steuer, Jeffrey, Jaeger, Steven, and Patterson, Dale, 1995, Long-term simulation of PCB export from the Fox River to Green Bay: Journal of Great Lakes Research, In- ternational Association for Great Lakes Research, v. 21, no. 3 , 1995 , p. 359-372.

Wentz, Dennis A., Rose, William J., and Webster, Katherine E., 1995 Long-term hydrologic and biogeochemical responses of a soft water seepage lake in north central Wisconsin: Water Resources Research, v. 31, no. 1, January 1995, p. 199-212.

Elder, John F., 1994, Distribution and grain-size partitioning of metals in bottom sediments of an experimentally acidified Wisconsin lake: Water Resources Bulletin, v. 30, no. 2, p. 251-259.

Hurley, J.P., Krabbenhoft, D.P., Babiarz, C.L., and Andren, A.W., 1994, Cycling processes of mercury across sediment/water interfaces in seepage lakes in Baker, L.A., ed., Environmental Chemistry of Lakes and Reservoirs: Advances in Chemistry Series, American Chemical Society, Washington, D.C., p. 426-449.

Krabbenhoft, David P., Bowser, Carl J., Kendall, Carol, and Gat, Joel R., 1994, Use of oxygen- 18 and deuterium to assess the hydrology of groundwater/lake systems in Baker, L.A., ed., Environmental Chemistry of Lakes and Reservoirs: Advances in Chemistry Series, American Chemical Society, Washington, D.C., p. 67-90.

Robertson, D.M., Anderson, W., and Magnuson, J.J., 1994, Relations between $\mathrm{El} \mathrm{Nino/Southern} \mathrm{Oscillation} \mathrm{events} \mathrm{and} \mathrm{the} \mathrm{climate} \mathrm{and}$ ice cover of lakes in Wisconsin, p. 48-57. in Greenland, D. ed., El Nino and Long-Term Ecological Research (LTER) Sites, Publication no. 18, LTER Network Office: University of Washington, Seattle, WA, $57 \mathrm{p}$.

Robertson, D.M. and Imberger, J., 1994, Lake Number, a quantitative indicator of mixing used to estimate changes in dissolved oxygen. Internationale Revue der gesamten: Hydrobiologie, v. 79, p. $159-176$

Teal, M.J., Ettema, R., and Walker, J.F., 1994, Estimation of mean flow velocity in ice-covered channels: Journal of Hydraulic Engineering, v. 120 , no. 12 , p. $1385-1400$.

Walker, John F., 1994, Methods for measuring discharge under ice cover: Journal of Hydraulic Engineering, v. 120, no. 11, p. 1327 1336.

Walker, John F., 1994, Statistical techniques for assessing water-quality effects of BMPs: Journal of Irrigation and Drainage Engineering, v. 120 , no. 2 , p. 334-347.

Bannerman, R.T., Owens, D.W., Dodds, R.B., and Hornewer, N.J., 1993, Sources of pollutants in Wisconsin stormwater: Water Science Technology, v. 28, no. 3-5, p. 241-259.

Fitzgerald, S.A., and Gardner, W.S., 1993, An algal carbon budget for pelagic/benthic coupling in Lake Michigan: Limnology and Oceanography, v. 28 , no. 3 , p. $547-560$

Walker, John F., and Graczyk, David J., 1993, Preliminary evaluation of effects of best management practices in the Black Earth Creek, Wisconsin, priority watershed: Water Science Technology, v. 28, no. $3-5$, p. $539-548$

Assel, R.A. and Robertson, D.M., 1992, Climatic changes near the Great Lakes inferred from 141-year ice records in proceedings of the 5th International Meeting on Statistical Climatology, Toronto, Canada, June, p. 81-85.

Krabbenhoft, D.P., Anderson, M.P., and Bowser, C.J., 1992, Reply to comment by Stauffer on "Estimating groundwater exchange with lakes using stable isotopes:".Water Resources Research, v. 28, no. 6 , p. 1751-1753.

Krabbenhoft, D.P., and Babiarz, C.L., 1992, Role of groundwater transport in aquatic mercury cycling: Water Resources Research, v. 28 , no. 12 , p. $3119-3128$. 
Luecke, C., Lunte, C.C., Wright, R.A., Robertson, D.M., and McLain, A.S., 1992, Impacts of variation in planktivorous fish on abundance of Daphnids: A simulation model of the Lake Mendota Food Web, in Kitchell, J.F. ed., Food Web Management - A Case Study of Lake Mendota: Springer-Verlag, New York, NY, 553 p.

Robertson, D.M., Ragotzkie, R.A., and Magnuson, J.J., 1992, Lake ice records used to detect historical and future climatic changes: Climatic Change, v. 21, p. 407-427.

Elder, J.F., and Collins, J.J., 1991, Freshwater molluses as indicators of bioavailability and toxicity of metals in surface-water systems: Reviews of Environmental Contamination and Toxicology, v. 122 , no. 4 , p. $37-79$.

Walker, J.F., 1991, Accuracy of selected techniques for estimating iceaffected streamflow: Journal of Hydraulic Engineering, v. 117, no. 6, p. 697-712.

Krabbenhoft, D.P., Anderson, M.P., and Boswer, C.J., 1990, Estimating groundwater exchange with lakes, 2 - Calibration of a threedimensional, solute transport model to a stable isotope plume: Water Resources Research, v. 26, no. 10, p. 2445-2462.

Krabbenhoft, D.P., Bowser, C.J., Anderson, M.P., and Valley, J.W., 1990 , Estimating groundwater exchange with lakes, 1 - Use of the stable isotope method: Water Resources Research, v. 26, no. 10 , p. 2445-2453.

Lodge, D.M., Krabbehoft, D.P., and Striegl, R.G., 1989, Groundwater velocity and abundance of grazing of crayfish as predictors of submersed macrophyte biomass in Sparkling Lake, Wisconsin: Limnology and Oceanography, v. 34, no. 1, p. 235-239.

Walker, J.F., Pickard, S.A., and Sonzogni, W.C., 1989, Spreadsheet watershed modeling for nonpoint-source pollution management in a Wisconsin basin: Water Resources Bulletin, v. 25, no. 1, p. 139-147.

Wentz, D.A., Garrison, P.J., and Bockheim, J.G., 1989, Section 7Chemical input-output budgets, in Knauer, D., and Brouwer, S.A., eds., The Wisconsin Regional Integrated Lake-Watershed Acidification Study (RILWAS): 1981-1983: Palo Alto, California, Electric Power Research Institute Report EA-6214, p. 7-1 to 7-30.

Wentz, D.A., and Rose, W.J., 1989, Interrelationships among hydrologic-budget components of a northern Wisconsin seepage lake and implications for acid-deposition modeling: Archives of Environmental Contamination and Toxicology, v. 18, p. 147-155.

Wentz, D.A., Rose, W.J., and Krohelski, J.T., 1989, Section 5-Hydrologic component, in Knauer, D., and Brouwer, S.A., eds., The Wisconsin Regional Integrated Lake-Watershed Acidification Study (RILWAS): 1981-1983: Palo Alto, California, Electric Power Research Institute Report EA-6214, p. 5-1 to 5-77.

Rochelle, B.P., Church, M.R., Gebert, W.A., Graczyk, D.J., and Krug, W.R., 1988, Relationship between annual runoff and watershed area for the eastern United States: Water Resources Bulletin, v. 24 , no. 1 , February 1988 , p. $35-41$.

Walker, J.F., 1988, General two-point method for determining velocity in open channel: ASCE Journal of Hydraulic Engineering, v. 114, no. 7, p. 801-805.

Graczyk, D.J., 1980, Flood insurance study of Verona, Dane County, Wisconsin, 3 fig., 3 pls.

Grant, R.S., and Graczyk, D.J., 1979, Flood insurance study of Hayward, Sawyer County, Wisconsin, $42 \mathrm{p}$.

Graczyk, D.J., 1978, Flood insurance study of Marathon City, Marathon County, Wisconsin, 1 fig., 3 pls.
Graczyk, D.J., 1978, Flood insurance study of Athens, Marathon County, Wisconsin, 3 figs., 3 pls. 

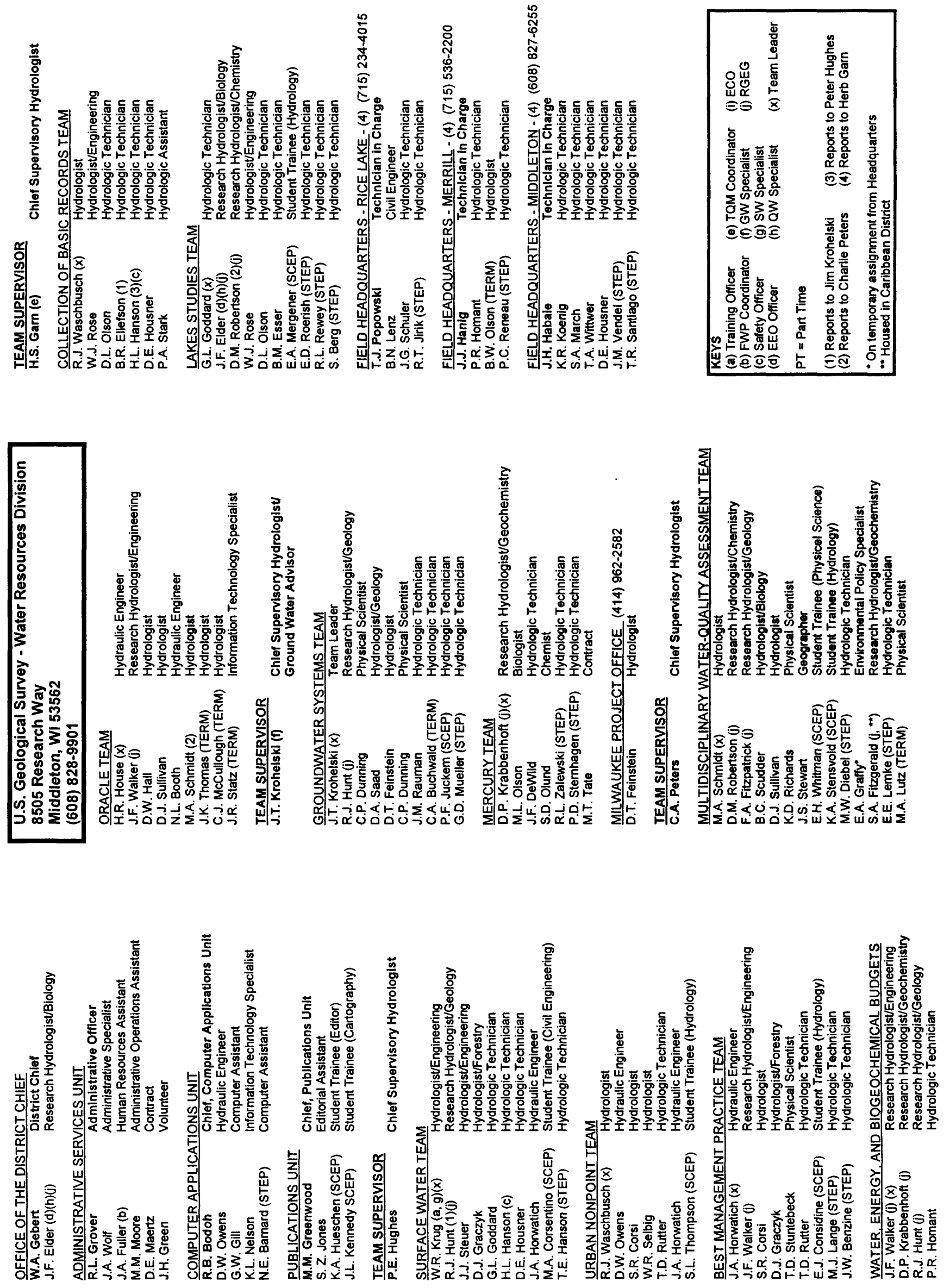